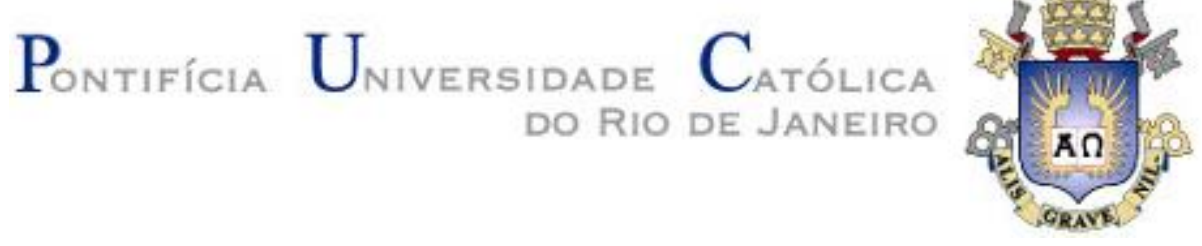

Guilherme Bravo de Oliveira Almeida

Incorporação de Escória de Cobre Pós-Jateada a um Solo Areno-Argiloso de Sergipe para Aplicação em Base de Pavimentos

Tese de Doutorado

Tese apresentada ao Programa de Pós-graduação em Engenharia Civil da PUC-Rio como requisito parcial para obtenção do grau de Doutor em Engenharia Civil.

Orientadora: Profa . Michéle Dal Tóe Casagrande Co-Orientador: Prof. Erinaldo Hilário Cavalcante 
Guilherme Bravo de Oliveira Almeida

\title{
Incorporação de Escória de Cobre Pós-Jateada a um Solo Areno-Argiloso de Sergipe para Aplicação em Base de \\ Pavimentos
}

Tese apresentada como requisito parcial pata obtenção do grau de Doutor pelo Programa de Pós-graduação em Engenharia Civil da PUC-Rio. Aprovada pela Comissão Examinadora abaixo assinada.

\author{
Prof ${ }^{\text {. }}$ Michéle Dal Toé Casagrande \\ Orientadora \\ Departamento de Engenharia Civil - PUC-Rio \\ Prof. Erinaldo Hilário Cavalcante \\ Co-Orientador \\ Departamento de Engenharia Civil - UFCG
}

Profa. Suelly Helena de Araújo Barroso

Departamento de Engenharia de Transportes - UFC

Profa . Ana Cristina Castro Fontena Sieira

Departamento de Engenharia Civil - UERJ

Prof. Ben-Hur de Albuquerque e Silva Seção de Engenharia de Fortificação e Construção - IME

Prof. Tácio Mauro de Campos Departamento de Engenharia Civil - PUC-Rio

Prof. Márcio da Silveira Carvalho Coordenador Setorial do Centro Técnico Científico - PUC-Rio 
Todos os direitos reservados. É proibida a reprodução total ou parcial do trabalho sem autorização da universidade, do autor e da orientadora.

\section{Guilherme Bravo de Oliveira Almeida}

Graduou-se em Engenharia Civil pela Universidade Federal de Sergipe em 2008. Mestre em Engenharia Civil pela Pontifícia Universidade Católica do Rio de Janeiro em 2011. Ingressou no doutorado em março de 2012, desenvolveu a tese na linha de pesquisa de pavimentação com utilização de novos materiais geotécnicos, sob a orientação da Prof ${ }^{a}$. Michéle Casagrande.

Ficha Catalográfica

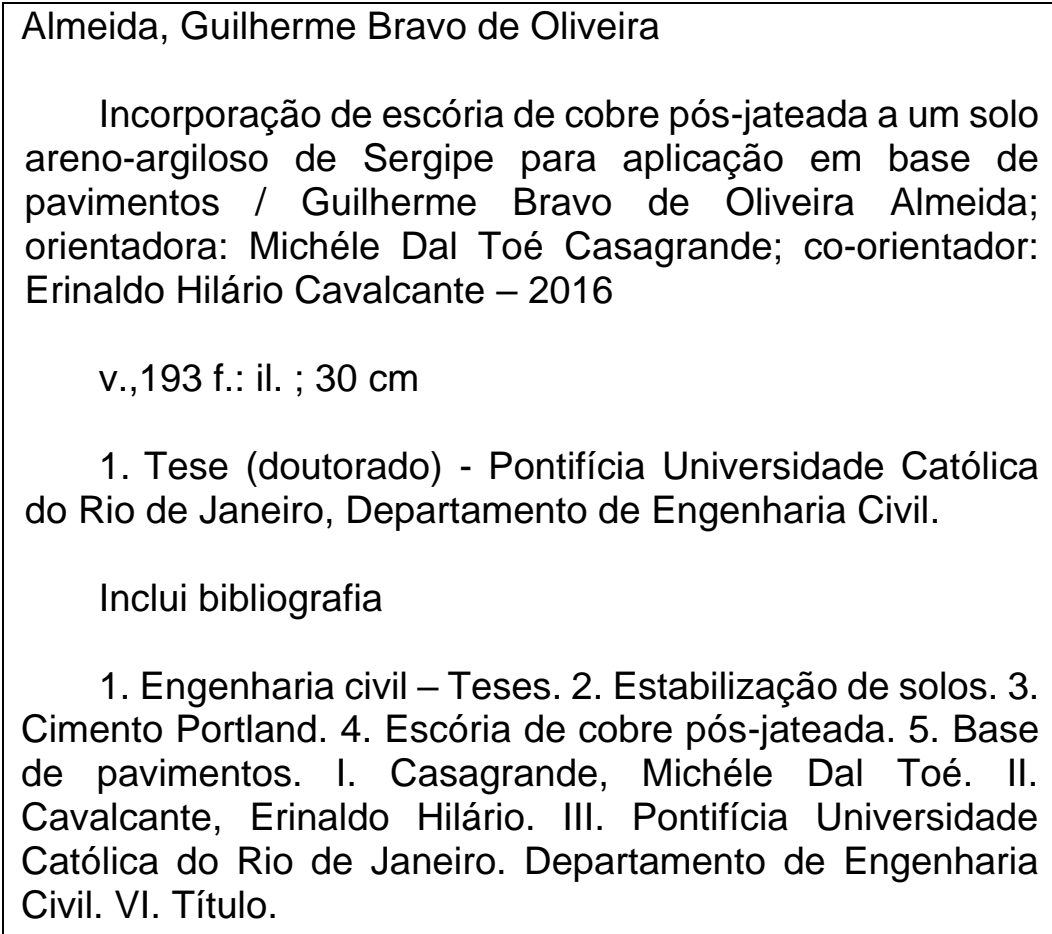

1. Engenharia civil - Teses. 2. Estabilização de solos. 3. Cimento Portland. 4. Escória de cobre pós-jateada. 5. Base de pavimentos. I. Casagrande, Michéle Dal Toé. II. Cavalcante, Erinaldo Hilário. III. Pontifícia Universidade Católica do Rio de Janeiro. Departamento de Engenharia Civil. VI. Título. 
Aos meus pais, Carlinhos e Ilka, aos meus irmãos, Thiago e Carlos Henrique e ao meu afilhado, Pedro, pelo incentivo, paciência e compreensão. 


\section{Agradecimentos}

Após longos dias de dedicação a esta pesquisa, agradeço a Deus pela força e serenidade na contínua caminhada.

Mas, para este sonho virar realidade, não seria possível sem o apoio da família, em especial aos meus pais e irmãos, que tanto apoiaram para que chegasse ao fim. Meu muito obrigado.

Aos vários amigos que de certa forma contribuíram com a finalização desse trabalho: Camila, Paula, Bábara, Fagner, Juliana, David, Rogério, Cleverton, Altran, Almir, Any....

Aos professores e amigos, Erinaldo e Angela, que tanto me apoiaram e contribuíram de forma positiva na pesquisa e com conselhos pessoais.

Aos irmãos Washington e Willami Santos, pelo convívio diário no GeoPav com contribuições de suas experiências na área da Geotecnia. Sou grato por todas as etapas que estiveram presentes na elaboração dessa pesquisa.

À equipe do GeoPav, sob a coordenação dos Profs. Erinaldo e Fernando e dos Técnicos Washington e Willami, tenho eterna gratidão, não só pelo uso dos equipamentos, quanto nos desabafos e ansiedades pessoais da tese. Jamais esquecerei desse acolhimento.

Agradeço aos professores pelo apoio físico nos seus respectivos Laboratórios pertencentes à UFS e que foram importantes na busca dos resultados aqui apresentados: Profa. Gisela e a Técnica Rose; Prof. Sandro e ao mestrando Thiago Nunes, Prof. Fred, Prof. Herbet, Prof. Rogério e o Técnico Cochiran, Profa. Rosane.

À Michéle Casagrande pela orientação e acompanhamento da pesquisa.

Ao CNPq / CAPES pela bolsa de pesquisa durante uma fase do doutorado. 


\section{Resumo}

Almeida, Guilherme Bravo de Oliveira; Casagrande, Michéle Dal Toé (Orientadora); Cavalcante, Erinaldo Hilário (Co-orientador). Incorporação de escória de cobre pós-jateada a um solo areno-argiloso de Sergipe para aplicação em base de pavimentos. Rio de Janeiro, 2016. 193p. Tese de Doutorado - Departamento de Engenharia Civil, Pontifícia Universidade Católica do Rio de Janeiro.

Uma grande quantidade de subprodutos é gerada por indústrias, surgindo a necessidade de encontrar um destino para estes resíduos. A escória de cobre proveniente do processo abrasivo é um exemplo que, após os ciclos de jateamento, é descartada no meio ambiente. A utilização desse resíduo na pavimentação pode ser uma alternativa de destino, além de evitar possíveis impactos ambientais. Esta pesquisa apresenta o estudo da incorporação da escória de cobre pós-jateada ao solo natural de Sergipe e cimento Portland. Os materiais utilizados foram solo arenoargiloso, escória proveniente de processo de jateamento e cimento de alta resistência inicial. O programa experimental envolveu ensaios de caracterização física, compactação, índice de suporte califórnia, dosagem físico-química, resistência à compressão simples, resistência à tração, módulo de resiliência, durabilidade, permeabilidade, análises químicas, mineralógicas e microscopia de varredura. O programa computacional SisPav foi utilizado para simular o dimensionamento das camadas do pavimento com o material pesquisado. Ficou constatado um teor de cimento entre 7 e $9 \%$ para melhoramento do solo, onde a adição de escória proporciona uma estabilização granulométrica com redução de cerca de 3\% de cimento, em relação ao compósito solo-cimento. A mistura com $30 \%$ de escória e 5\% de cimento alcançou maiores picos de resistência, maior módulo de resiliência, baixa perda de massa, mesma resistência à tração em relação à mistura de solo-cimento sem escória, bem como redução da permeabilidade em relação ao solo puro. Os resultados possibilitaram indicar o emprego da escória de cobre pós-jateada em misturas com solo-cimento para aplicação em base de pavimentos, contribuindo em uma ação mitigadora dos impactos ao meio ambiente com um fim mais nobre a esse resíduo.

\section{Palavras - chave}

Estabilização de Solos; Cimento Portland; Escória de Cobre Pós-Jateada; Base de Pavimentos. 


\section{Abstract}

Almeida, Guilherme Bravo de Oliveira; Casagrande, Michéle Dal Toé (Advisor); Cavalcante, Erinaldo Hilário (Co-advisor). Post-Blasting Copper Slag Incorporation in a Sand-Clayey Soil from Sergipe for Pavements Base Application. Rio de Janeiro, 2016. 193p. DSc. Thesis - Departamento de Engenharia Civil, Pontifícia Universidade Católica do Rio de Janeiro.

A large amount of by-products is generated by industries, becoming needed to find a destination for these wastes. Copper slag from the abrasive process is an example, which, after the blasting cycles, is discarded into the environment. The use of this residue in the paving can be an alternative destination, besides avoiding possible environmental impacts. This research presents the study of the incorporation of post-blasted copper slag to the natural soil of Sergipe and Portland cement. The materials used were sand-clayey soil, slag from blasting process and cement of high early strength. Laboratory tests carried out involved geotechnical characterization, compaction, california bearing ratio, physic-chemical dosage, unconfined compressive strength and tensile strength, resilient modulus, durability test, permeability test, chemical and mineralogical analysis and microscopy. The computer program SisPav was used to simulate the design of pavement of the researched material. It was observed a cement content between 7 and $9 \%$ for the soil and that the slag provides a granulometric stabilization with reduction of about $3 \%$ of cement, in relation to the soil-cement. The mixture with $30 \%$ of slag and $5 \%$ of cement reached highest strength and resilient modulus, lowest mass loss, same tensile strength compared to the mixture without slag, and reduced permeability compared to natural soil. The results indicate the use of post-blasted copper slag in mixtures with soil-cement for application in the base of pavements, contributing in a mitigating action of the impacts to the environment with a more noble purpose to this residue.

\section{Keywords} Base.

Soils Stabilization; Porland Cement; Post-blasting Copper Slag; Pavements 


\section{Sumário}

1 Introdução 22

1.1 Relevância e justificativa da pesquisa 22

1.2 Objetivos 25

1.3 Organização da tese 25

2 Revisão bibliográfica $\quad 27$

2.1 Considerações sobre a estabilização de solos 27

2.2 Métodos de estabilização de solos 29

2.2.1 Estabilização mecânica 30

2.2.2 Estabilização química 31

2.3 Estabilização de solo com cimento Portland 49

2.3.1 Considerações iniciais 49

2.3.2 Componentes da estabilização do solo-cimento 51

2.3.3 Mecanismos de estabilização do solo-cimento 57

2.3.4 Fatores que influenciam a estabilização de solo com cimento $\begin{array}{ll}\text { Portland } & 61\end{array}$

2.4 Escória de cobre $\quad 69$

2.4.1 Breve histórico e produção mundial de cobre 69

2.4.2 Caracterização geral da escória de cobre 72

2.4.3 Aplicações da escória de cobre 75

2.4.4 Impactos ambientais do uso da escória de cobre 80

2.5 Considerações finais 83

3 Materiais e métodos 84

3.1 Solo 84

3.2 Escória de cobre pós-jateada 86

3.3 Cimento Portland 88

3.4 Ensaios $\quad 88$

3.4.1 Caracterização $\quad 89$

3.4.2 Compactação 90

3.4.3 Índice de suporte califórnia - ISC 90

3.4.4 Resistência à compressão simples - RCS 90 
3.4.5 Módulo de resiliência - MR 92

3.4.6 Resistência à tração por compressão diametral 97

3.4.7 Durabilidade 98

3.4.8 Ensaio de permeabilidade 98

3.4.9 Dosagem físico-química $\quad 100$

3.4.10 Caracterização mineralógica 102

3.4.11 Microscopia eletrônica de varredura 103

3.4.12 Lixiviação e solubilização 103

3.5 Dimensionamento do pavimento típico 105

3.6 Considerações finais 106

4 Resultados e análises $\quad 107$

$\begin{array}{ll}\text { 4.1 Caracterização do solo } & 107\end{array}$

4.2 Caracterização físico-química da escória de cobre $\quad 114$

4.3 Caracterização das misturas de solo e escória de cobre $\quad 120$

4.4 Caracterização das misturas de solo e cimento Portland e dosagem do aditivo 127

4.5 Caracterização das misturas se solo, escória de cobre e cimento Portland $\quad 135$

4.6 Correlações entre os parâmetros obtidos dos ensaios de resistência 158

$\begin{array}{ll}\text { 4.7 Considerações finais } & 165\end{array}$

5 Dimensionamento de um pavimento com material de estudo 166

5.1 Simulações do pavimento 169

5.2 Considerações finais 174

6 Conclusões e recomendações 175

6.1 Principal contribuição da pesquisa 175

6.2 Principais constatações do programa experimental 175

6.3 Recomendações para trabalhos futuros 177

7 Referências bibliográficas $\quad 179$ 


\section{Lista de figuras}

Figura 2.1 Tipos de solo-agregados

(Yoder e Witczak, 1975 apud Bernucci et al., 2007).

Figura 2.2 Agente estabilizante em função do tipo do tipo de solo (Little, 1995 apud Cruz e Jalali, 2010).

Figura 2.3 Mecanismos de estabilização solo-cal (Inglês e Metcalf, 1972 apud Lopes, 2011).

Figura 2.4 Distribuição do filme betuminoso na massa de solo (Kézdi, 1979 apud Miceli Jr., 2006).

Figura 2.5 Esquema de solo com a) alto teor de cimento e

b) baixo teor de cimento (Catton, 1962 apud Cruz, 2004).

Figura 2.6 Modelo da estrutura matriz-esqueleto do solo-cimento (Herzog, 1967 apud Rodrigues, 1992).

Figura 2.7 Micrografia óptica (200x) de uma mistura solo-cimento (a) e de concreto (b) (Santos, 2008).

Figura 2.8 Micrografia óptica (200x) de uma mistura de areia monogranular e $8 \%$ de cimento (Santos, 2008).

Figura 2.9 Efeito do teor de cimento na resistência para vários tipos de solo (METCALF, 1969 apud MARANGON, 1992).

Figura 2.10 Resistência à compressão versus idade (em dias) para diferentes misturas solo/cimento (adaptada deLasisi e Ogunjide, 1984).

Figura 2.11 Teor de cimento em massa, para o ensaio de compressão simples, em função da porcentagem de material menor do que $0,05 \mathrm{~mm}$ e da massa específica aparente seca máxima (NBR 12253/92).

Figura 2.12 Teor de cimento em massa, para o ensaio de compressão simples, em função da porcentagem de material menor do que $0,05 \mathrm{~mm}$ e de material retido na peneira n० 4 e da massa específica aparente seca máxima (NBR 12253/920.

Figura 2.13 Efeito da densidade na resistência de uma argila estabilizada com $10 \%$ de cimento (Ingles e Metcalf, 1972 apud Concha, 1986).

Figura 2.14 Densidade seca versus tempo decorrido desde o fim da mistura de dois materiais estabilizado com $10 \%$ de cimento (adaptado de Sherwood, 1993 apud Makusa, 2012).

Figura 2.15 Efeito do tempo de cura para os solos estabilizados com 5\% de cimento (METCALF, 1969 apud MARANGON, 1992).

Figura 2.16 Escória de cobre: a) resfriada ao ar (Resende, 2009) e b) granulada. 
Figura 2.17 Grão da escória de cobre (ampliação 50x)

(ZAIN et al., 2004).

Figura 2.18 Difratograma da escória de cobre (Moura, 2000). 75

Figura 3.1 Localização da jazida Aningas.

Figura 3.2 Visão parcial da jazida Aningas. 86

Figura 3.3 Tanque em manutenção - face externa (ANJOS, 2015). 86

Figura 3.4 Escória de cobre antes e após o processo de jateamento (ANJOS, 2015).

Figura 3.5 Amostra de escória de cobre utilizada na pesquisa. 87

Figura 3.6 Secagem (a), destorroamento (b) e quarteamento (c). $\quad 89$

Figura 3.7 Prensa de resistência à compressão simples

EMIC DL 20000 (a) e INSTRON 3385H (b). 92

Figura 3.8 Equipamento para determinação do módulo de resiliência do GeoPav: (a) módulo de ensaio e (b) módulo de controle.

93

Figura 3.9 Corpos de prova para ensaio de MR: (a) moldagem em cilindro bipartido e (b) cura em câmara úmida.

Figura 3.10 Montagem do corpo de prova para o ensaio:

(a) colocação das membranas e (b) anéis de suporte para o par de LVDTs.

Figura 3.11 Corpo de prova na célula triaxial para realização do ensaio: (a) assentamento na base, (b) posicionamento do cabeçote, (c) fixação dos LVDTs nos anéis de suporte e (d) vedação da célula triaxial.

Figura 3.12 Corpos de prova submetidos à cura em câmara úmida por 7 dias.

Figura 3.13 Prensa de rompimento à tração dos corpos de prova. $\quad 98$

Figura 3.14 Ensaio de permeabilidade de carga variável. 99

Figura 3.15 Dosagem físico-química do solo e cimento Portland. 101

Figura 3.16 Preparação da amostra para ensaio de difração de raios $X$ (a) e lâmina para ensaio (b).

102

Figura 3.17 Procedimento para obtenção do extrato lixiviado da escória de cobre pós-jateada.

104

Figura 3.18 Procedimento para obtenção do extrato solubilizado da escória de cobre pós-jateada.

105

Figura 3.19 Fluxograma do SisPav (Franco, 2007). 106

$\begin{array}{ll}\text { Figura 4.1 Curvas granulométricas das amostras de solo puro. } & 107\end{array}$

Figura 4.2 Gráfico 3D do modelo composto do módulo de resiliência do solo puro.

Figura 4.3 Difratograma de raios $X$ das amostras de solo puro. 
Figura 4.4 Curvas granulométricas das amostras de escória de cobre pós-jateada.

Figura 4.5 Microscopia eletrônica de varredura das amostras de escória de cobre pós-jateada.

Figura 4.6 Difratograma de raios $X$ da escória de cobre pós-jateada. 119

Figura 4.7 Curvas granulométricas das amostras de solo, de misturas e de escória de cobre pós-jateada.

Figura 4.8 Histograma da granulometria das misturas solo-escória de cobre pós-jateada.

Figura 4.9 Análise de variância da \% de escória de cobre pós-jateada. 126

Figura 4.10 Microscopia eletrônica de varredura da mistura solo e $30 \%$ de escória de cobre pós-jateada.

Figura 4.11 Dosagem físico-química do solo.

Figura 4.12 Curvas de RCS versus Deformação para misturas solo e cimento Portland.

Figura 4.13 Ruptura de corpos de prova com $3 \%$ de cimento após rompimento à compressão simples.

Figura 4.14 Resistência à compressão simples $(\mathrm{MPa})$ versus teor de cimento (\%) do solo.

Figura 4.15 Torrões da mistura solo e 3\% (a), $5 \%$ (b), $7 \%$ (c) e $9 \%$ (d) de cimento Portland, após o ensaio de RCS.

Figura 4.16 Análise de variância da \% de cimento Portland.

Figura 4.17 Dosagem físico-química do solo, 10 e 20\% de escória de cobre pós-jateada.

Figura 4.18 Dosagem físico-química: (a) solo puro + $3 \%$ cimento Portland e (b) mistura de solo $+20 \%$ escória de cobre pós-jateada $+3 \%$ cimento Portland.

Figura 4.19 Resistência à compressão simples $(\mathrm{MPa})$ versus teor de cimento Portland (\%) do solo e da mistura solo e 10\% de escória de cobre pós-jateada.

Figura 4.20 Curvas de RCS versus Deformação para misturas com $3 \%$ de cimento Portland e porcentagens de escória de cobre pós-jateada.

Figura 4.21 Curvas de RCS versus Deformação para as misturas com $5 \%$ de cimento Portland e porcentagens de escória de cobre pós-jateada.

Figura 4.22 Ruptura de corpos de prova com $30 \%$ de escória e $5 \%$ cimento após rompimento à compressão simples.

Figura 4.23 Resistência à compressão simples $(\mathrm{MPa})$ versus teor de escória de cobre pós-jateada (\%) para 5\% de cimento Portland. 
Figura 4.24 Corpo de prova do ensaio com $3 \%$ de cimento Portland e $10 \%$ de escória de cobre pós-jateada.

Figura 4.25 Análise de variância para 10\% de escória em relação à \% de cimento.

Figura 4.26 Análise de variância para $20 \%$ de escória em relação à \% de cimento.

Figura 4.27 Análise de variância para 30\% de escória em relação à \% de cimento.

Figura 4.28 Análise de variância para $40 \%$ de escória em relação à \% de cimento.

Figura 4.29 Análise de variância para $3 \%$ de cimento em relação à \% de escória.

Figura 4.30 Análise de variância para $5 \%$ de cimento em relação à \% de escória.

Figura 4.31 Microscopia eletrônica de varredura da mistura solo, $30 \%$ de escória de cobre pós-jateada e $5 \%$ de cimento Portland.

Figura 4.32 Microscopia eletrônica de varredura da mistura solo, $30 \%$ de escória de cobre pós-jateada e $3 \%$ de cimento Portland.

Figura 4.33 Corpos de prova após o ensaio de durabilidade:

(a) solo e $5 \%$ de cimento Portland e (b) solo, 30\% escória de cobre pós-jateada e $5 \%$ de cimento Portland.

152

Figura 4.34 Gráfico 3D do modelo composto do módulo de resiliência da mistura solo, $30 \%$ de escória e $5 \%$ de cimento.

154

Figura 4.35 Gráfico 3D do modelo composto do módulo de resiliência da mistura solo, $30 \%$ de escória e $5 \%$ de cimento após o ensaio de durabilidade.

Figura 4.36 Gráfico 3D do modelo composto do módulo de resiliência da mistura solo e $5 \%$ de cimento.

Figura 4.37 Módulo de resiliência versus tensão desvio para as misturas e o solo puro.

Figura 4.38 Módulo de resiliência (MPa) versus tensão desvio (MPa) para as misturas e o solo puro, em escala logarítmica.

Figura 4.39 Corpos de provas do ensaio com $5 \%$ de cimento e em (a) com $30 \%$ de escória e em (b) $0 \%$ de escória.

Figura 4.40 Resistência à compressão simples versus teor de cimento.

Figura 4.41 Resistência à compressão simples versus porcentagem de escória de cobre.

Figura 4.42 Resistência â compressão simples versus fator água/cimento.

Figura 4.43 Resistência à compressão simples versus Vv/Vci. 
Figura 5.1 Tela SisPav na aba < carregamento > para o cálculo do tráfego.

Figura 5.2 Tela SisPav na aba < clima >.

Figura 5.3 Estrutura 1 do pavimento simulado.

Figura 5.4 Tela SisPav do dimensionamento revestimento de CA $(5 \mathrm{~cm})$, base de solo $+30 \%$ escória $+5 \%$ cimento $(30 \mathrm{~cm})$ e sub-base de solo puro $(30 \mathrm{~cm})$.

Figura 5.5 Tela SisPav do dimensionamento revestimento de TS $(2,5 \mathrm{~cm})$, base de solo $+30 \%$ escória $+5 \%$ cimento $(30 \mathrm{~cm})$ e sub-base de solo puro $(30 \mathrm{~cm})$.

Figura 5.6 Estrutura 2 do pavimento simulado.

Figura 5.7 Tela SisPav do dimensionamento revestimento de CA $(5 \mathrm{~cm})$, base de solo $+30 \%$ escória $+5 \%$ cimento $(30 \mathrm{~cm})$.

Figura 5.8 Tela SisPav do dimensionamento revestimento de TS $(2,5 \mathrm{~cm})$, base de solo $+30 \%$ escória $+5 \%$ cimento $(30 \mathrm{~cm}) . \quad 172$

Figura 5.9 Estrutura 3 do pavimento simulado.

Figura 5.10 Tela SisPav do dimensionamento revestimento de CA $(5 \mathrm{~cm})$, base de solo puro $(20 \mathrm{~cm})$ e sub-base de solo $+30 \%$ escória $+5 \%$ cimento $(25 \mathrm{~cm})$.

Figura 5.11 Tela SisPav do dimensionamento revestimento de TS $(2,5 \mathrm{~cm})$, base de solo puro $(20 \mathrm{~cm})$ e sub-base de solo $+30 \%$ escória $+5 \%$ cimento $(25 \mathrm{~cm})$. 


\section{Lista de tabelas}

Tabela 2.1 Composição em óxidos dos cimentos nacionais (Petrucci, 2005).

Tabela 2.2 Reserva e produção mundial de cobre (DNPM, 2015).

Tabela 2.3 Geração da escória de cobre em várias regiões do mundo (Gorai et al., 2003).

Tabela 2.4 Composição química de algumas escórias de cobre (SHI et al., 2008).

Tabela 2.5 Composição granulométrica da escória de cobre da Caraíbas Metais, segundo Moura (2000).

Tabela 2.6 Resultados dos ensaios de lixiviação (Moura, 2000). 81

Tabela 2.7 Resultado dos ensaios de solubilização (Moura, 2000). 82

Tabela 3.1 Coordenadas do ponto de coleta na jazida Aningas. 86

Tabela 3.2 Sequência de tensões para fase de condicionamento (DNER - ME - 134/2010).

Tabela 3.3 Sequência de tensões para determinação do módulo de resiliência (DNER - ME - 134/2010).

Tabela 4.1 Resultados da análise granulométrica das amostras de solo puro.

108

Tabela 4.2 Limites de Atterberg das amostras de solo puro.

108

Tabela 4.3 Dados de parte da granulometria, limites de Atterberg e ISC das amostras de solo puro.

Tabela 4.4 Resistência à compressão simples e da umidade de moldagem dos corpos de prova do solo puro.

Tabela 4.5 Parâmetros de resistência e coeficiente de determinação obtidos a partir dos modelos para os ensaios de MR das amostras de solo puro.

Tabela 4.6 Constituição química das amostras do solo puro.

Tabela 4.7 Resultados da análise granulométrica das amostras de escória de cobre pós-jateada.

Tabela 4.8 Resultados do ensaio de lixiviação das amostra de escória de cobre pós-jateada - comparação com a listagem apresentada no anexo F da NBR 10004/2004.

Tabela 4.9 Resultados do ensaio de solubilização das amostras de escória de cobre pós-jateada - comparação com a listagem apresentada no anexo G da NBR 10004/2004.

Tabela 4.10 Composição química das amostras de escória de cobre original. 
Tabela 4.11 Composição química das amostras de escória de cobre pós-jateada.

Tabela 4.12 Resultado da análise granulométrica de misturas solo-escória de cobre pós-jateada.

Tabela 4.13 Densidade real dos grãos da mistura solo e escória de cobre pós-jateada.

Tabela 4.14 Limites de Atterberg da mistura solo e escória de cobre pós-jateada.

Tabela 4.15 Dados de parte da granulometria, limites de Atterberg, índice de grupo e classificação da mistura de solo e escória de cobre pós-jateada.

Tabela 4.16 Peso específico aparente seca máximo e umidade ótima das misturas solo e escória de cobre pós-jateada.

Tabela 4.17 Resistência à compressão simples das misturas solo e escória de cobre pós-jateada.

Tabela 4.18 Limites de Atterberg da mistura solo e escória de cobre pós-jateada de amostras pós-RCS.

Tabela 4.19 Peso específico aparente seco máximo e umidade ótima das misturas solo e cimento Portland.

Tabela 4.20 Resistência à compressão simples das misturas solo e cimento Portland.

Tabela 4.21 Limites de Atterberg da mistura solo e cimento Portland de amostras pós-RCS.

Tabela 4.22 Peso específico aparente seco máximo e umidade ótima das misturas solo, escória de cobre pós-jateada e cimento Portland.

Tabela 4.23 Resistência à compressão simples das misturas solo, escória de cobre pós-jateada e cimento Portland.

Tabela 4.24 Resultado do ensaio de lixiviação da mistura solo, 30\% escória de cobre pós-jateada e 5\% cimento Portland - comparação com a listagem apresentada no anexo F da NBR 10004/2004.

Tabela 4.25 Parâmetros de resistência e coeficiente de determinação obtidos a partir dos modelos para os ensaios de MR, da mistura solo, $30 \%$ de escória de cobre pós-jateada e $5 \%$ de cimento Portland.

Tabela 4.26 Parâmetros de resistência e coeficiente de determinação obtidos a partir dos modelos para os ensaios de MR, da mistura solo, $30 \%$ de escória de cobre pós-jateada e $5 \%$ de cimento Portland de corpos de prova após ensaio de durabilidade.

Tabela 4.27 Parâmetros de resistência e coeficiente de determinação obtidos a partir dos modelos para os ensaios de MR, da mistura solo e $5 \%$ de cimento Portland. 
Tabela 4.28 Resistência à tração por compressão diametral do solo, escória de cobre pós-jateada e cimento Portland.

Tabela 4.29 Comparação de resistência à compressão simples entre as Equações 1 e 2 e os resultados ensaiados.

Tabela 4.30 Dados gerais de cada amostra. 


\section{Lista de quadros}

Quadro 2.1 Tipo de cimento Portland, segundo ABCP (2014).

Quadro 2.2Características da estabilização de solos com cimento (Pereira, 1970 apud Cruz, 2004).

Quadro 3.1 Ensaios realizados no programa experimental.

89 


\section{Lista de abreviaturas}

AASHTO American Association of State Highway and

Transportation Officials

ABCP Associação Brasileira de Cimento Portland

ABEDA Associação Brasileira das Empresas Distribuidoras de

Asfalto

ABNT Associação Brasileira de Normas Técnicas

ACAA American Coal Ash Association

ASTM American Society for Testing and Materials

$\mathrm{BC}$

Cimento Portland de Baixo Calor de Hidratação

CA Concreto Asfáltico

CBR California Bearing Ratio

CPB Cimento Portland Branco

CP I

Cimento Portland Comum

CP I-S Cimento Portland Comum com Adição

CP II-E Cimento Portland com Escória

CP II-F $\quad$ Cimento Portland com Filer

CP II-Z Cimento Portland com Pozolana

CP III Cimento Portland de Alto-forno

CP IV Cimento Portland Pozolânico

CP V-ARI Cimento Portland de Alta Resistência Inicial

DNER Departamento Nacional de Estradas de Rodagem

Dnit Departamento Nacional de Infraestrutura de Transporte

DNPM Departamento Nacional de Produção Mineral

Embrapa Empresa Brasileira de Pesquisa Agropecuária

GEOPAV Laboratório de Geotecnia e Pavimentação

ICSG International Copper Study Group

IG Índice de Grupo

IME Instituto Militar de Engenharia

IP Índice de Plasticidade

ISC Índice de Suporte Califórnia

ITPS Instituto Tecnológico e de Pesquisas do Estado de

Sergipe 
LVDT Linear Variable Differential Transformer

LL $\quad$ Limite de Liquidez

LP Limite de Plasticidade

MEV Microscopia Eletrônica de Varredura

MME Ministério de Minas e Energia

MR Módulo de Resiliência

PCA Portland Cement Association

Procobre Instituto Brasileiro do Cobre

RCS Resistência à Compressão Simples

RS Cimento Portland Resistente a Sulfatos

SIEMBS Sistema Integrado de Ensaios para Misturas Betuminosas

e Solos

TRB Transportation Reserch Board

TS Tratamento Superficial

UERJ Universidade Estadual do Rio de Janeiro

UFC Universidade Federal do Ceará

UFCG Universidade Federal de Campina Grande

UFS Universidade Federal de Sergipe

UNIT Universidade Tiradentes

USCS Unified System Classification of Soil

USGS United States Geological Survey

UTM Universal Transversa de Mercator 


\section{Lista de símbolos}

$\sigma_{3} \quad$ Tensão confinante

$\sigma_{d} \quad$ Tensão desvio

$\mathrm{k}_{1}, \mathrm{k}_{2}, \mathrm{k}_{3}$ Constantes de regressão

k Coeficiente de permeabilidade

a Área da bureta

L Comprimento da amostra de solo

A Área da amostra de solo

$\Delta \mathrm{t} \quad$ Variação de tempo entre as leituras

$\mathrm{h}_{1}$ e h2 Cargas no instante 1 e 2 , respectivamente

k20 Coeficiente de permeabilidade referido à temperatura de $20^{\circ} \mathrm{C}$

Rt Relação entre viscosidade da água na temperatura de ensaio e a viscosidade da água a $20^{\circ} \mathrm{C}$

$\Delta \mathrm{V} \quad$ Variação volumétrica

$\gamma_{\mathrm{d}} \quad$ Massa específica aparente seca máxima

e Índice de vazios

n Porosidade

$\omega \quad$ Umidade

Vv Volume de vazios

Vci Volume de cimento

a/ci Fator água/cimento 


\section{1 \\ Introdução}

\section{1 Relevância e justificativa da pesquisa}

O crescimento das cidades de um modo geral leva a exploração de recursos naturais com a retirada de solos destinados à construção civil. Perante o espraiamento do município de Aracaju após a década de 70, jazidas localizadas nos arredores dessa capital foram sendo exploradas aceleradamente até esgotar o solo de melhor qualidade para utilizar em aterros, em obras de pavimentação das grandes avenidas e ruas do município. Como exemplo, o Bairro Coroa do Meio, Zona Sul de Aracaju, onde a maior parte do bairro foi aterrado com material nobre proveniente de uma jazida localizada no Bairro Santa Maria, região limítrofe entre os municípios Aracaju e São Cristóvão.

Ao longo do tempo, novas jazidas foram sendo autorizadas para exploração e outras abertas ilegalmente. No entanto, algumas daquelas ou não apresentam materiais de qualidade ou, quando apresentam qualidade, o custo de transporte encarece a sua utilização. Além disso, há jazidas que não possuem material suficiente para exploração a longo prazo.

Dessa forma, as opções de fonte de material terroso estão em áreas localizadas no interior do Estado de Sergipe, como nos municípios de Itaporanga d'Ajuda e Itabaiana. Nestes locais ainda há material de qualidade que podem ser utilizados na pavimentação e as jazidas encontram-se a 60 km, em média, da capital. Materiais nobres também podem ser encontrados no município de Japoatã, cerca de $100 \mathrm{~km}$ de Aracaju, mas pela distância torna o custo de transporte elevado.

Se o desenvolvimento das cidades leva a construção civil a consumir um montante de matéria-prima, é no setor da pavimentação que esse consumo é muito elevado. Sabe-se que a estrutura do pavimento é composta por camadas de materiais que possuem características apropriadas à sua utilização, com objetivo maior do desempenho satisfatório, baseado na composição de sua estrutura, de forma a permanecer em serviço durante a sua vida de projeto. 
Entretanto, nem sempre os materiais encontrados na natureza não atendem às características necessárias para a função que se destinam, devendo-se escolher alternativas mais indicadas. Entre as opções, a estabilização de solo visa, sobretudo, a melhoria das suas propriedades mecânicas e a manutenção das suas características ao longo do tempo. Dos métodos, a estabilização química e granulométrica é uma prática na construção de pavimentos.

A estabilização química com cimento Portland é uma alternativa para melhorar a plasticidade, sensibilidade, resistência e durabilidade do solo natural. Porém, é interessante avaliar o teor ideal para determinado tipo de solo, uma vez que acréscimo de cimento ao solo poderá representar pouco ganho de resistência e acarretar em custos elevados que inviabiliza a estabilização. A restrição quanto ao uso do cimento para estabilizar um solo ocorre para solos mais argilosos, quando o consumo do aditivo se torna maior.

Já a estabilização granulométrica é o método que modifica o arranjo das partículas por meio da alteração na granulometria. Nesse método, a distribuição de porções de grãos menores e preenchem os vazios deixados pelos grãos maiores, implicando em um maior contato entre eles e, consequentemente, na estabilização. Da mesma forma que na estabilização química, é interessante avaliar o teor ideal do material utilizado para a estabilizar o solo, pois maiores quantidades de grãos podem alterar o contato entre eles e reduzir a resistência da mistura.

O uso de resíduos como matéria-prima na pavimentação resulta na diminuição do consumo dos recursos naturais e, provavelmente, poderá reduzir os custos com a exploração desses recursos. Por outro lado, o aproveitamento de resíduos também visa contribuir com a redução dos grandes depósitos desses materiais descartados, evitando possíveis passivos ambientais, além da redução no consumo energético despendido para a extração dos recursos naturais.

Anualmente, uma grande quantidade de subprodutos é produzida por uma série de indústrias, surgindo a necessidade de se encontrar alternativas de destino para a enorme variedade de resíduos. Entre os princípios da Política Nacional de Resíduos Sólidos (Lei n 12.305/2010) está a responsabilidade compartilhada de maneira a minimizar o volume de resíduos e rejeitos gerados e reduzir os impactos causados. A reutilização e a reciclagem dos resíduos sólidos, inseridos nos objetivos dessa Política, são alternativas que podem diminuir os volumes gerados e, consequentemente, os impactos ao meio ambiente. 
O destino de alguns resíduos, tais como: plástico, vidro, alumínio, sucata, está associada ao próprio ciclo de produção das respectivas indústrias, isto é, coleta do produto já utilizado e sua reciclagem pela indústria que o originou. Porém, há resíduos que não retornam ao ciclo de produção, constituindo-se uma fonte de preocupação, pois esses resíduos provocam impactos negativos.

A escória de cobre é um subproduto da indústria do cobre que não retorna ao ciclo produtivo na metalúrgica, podendo ser utilizada em uma série de aplicações, dentre elas, como abrasivos. A escória quando utilizada como abrasivo no processo de jateamento denomina-se granalha de cobre e, após um determinado número de aplicações, a granalha torna-se um resíduo não servível no jateamento, por perder suas características, sendo então descartadas no meio ambiente.

A escória utilizada no processo abrasivo apresenta alterações físicas, devido a ação mecânica sobre a superfície, em geral metálica, que tritura os grãos, modificando a forma e o tamanho dos grãos. Além de alterações químicas, por carrear partículas da superfície, que modificam a composição em relação à escória original e a densidade, por carrear partículas da superfície metálica.

Diante desse contexto, esta pesquisa apresenta um estudo do solo do Estado de Sergipe, estabilizado granulometricamente com resíduo de escória de cobre e estabilizado quimicamente com cimento Portland. A escória provém do processo abrasivo da parte externa de tanques de armazenamento de petróleo onde, após três repetições no processo de jateamento, a escória é descarta por apresentar menor capacidade abrasiva.

Para uma possível disposição final ambientalmente adequada, além de contribuir com os poucos estudos com solos do Estado de Sergipe, esta pesquisa tem como contribuição uma opção de destino da escória de cobre pós-jateada, possibilitando o aproveitamento de um resíduo que é descartado em aterro sanitário, podendo ser incorporado à mistura de solo-cimento em unidades de geração do resíduo após o jateamento. 


\section{2 \\ Objetivos}

O objetivo geral desta pesquisa é estudar a incorporação do resíduo escória de cobre pós-jateada ao solo natural de Sergipe em misturas com cimento Portland, para aplicação em camadas de base de pavimentos.

Do objetivo geral estruturam-se os seguintes objetivos específicos:

$\checkmark$ Realizar caracterizações física, mecânica, química e ambiental dos materiais estudados e misturas;

Verificar as diferentes dosagens de cimento Portland e de escória de cobre ao solo, bem como a influência destes materiais quando adicionados ao solo;

$\checkmark$ Analisar as modificações físicas, mecânicas e de permeabilidade que a escória de cobre pós-jateada e o cimento proporcionam ao solo;

$\checkmark$ Verificar as diferentes imagens microscópicas para misturas solo-escóriacimento que explicam o comportamento das misturas;

$\checkmark$ Simular um dimensionamento da estrutura do pavimento com os materiais estudados e avaliar a aplicabilidade destes como uso em base de pavimentos.

\section{3 \\ Organização da tese}

A tese está organizada da seguinte forma:

- Capítulo 2 - aborda conceitos relativos à estabilização dos solos, os métodos de estabilização, com foco na estabilização química com cimento Portland, e as informações a respeito da escória de cobre, suas aplicações e impactos ambientais.

- Capítulo 3 -é descrito todo o programa experimental a respeito dos ensaios realizados: caracterização física (granulometria, densidade real e limites de Atterberg), compactação (Proctor intermediário), dosagem físico-química de solocimento-escória, módulo de resiliência, resistência à compressão simples e à tração, durabilidade, permeabilidade, análise química e mineralógica, microscopia eletrônica.

- Capítulo 4 - dedicado aos resultados obtidos e análises das alterações proporcionadas com adição dos percentuais de cimento Portland e de escória de cobre. 
- Capítulo 5 - utilização do programa computacional SisPav para simular o dimensionamento das camadas de um pavimento utilizando os dados obtidos nessa pesquisa.

- Conclusões e recomendações - destina-se a descrição da principal contribuição da pesquisa, das constatações observadas no programa experimenta bem como as recomendações para trabalhos futuros.

- Referências bibliográficas. 


\section{2 \\ Revisão Bibliográfica}

\section{1 \\ Considerações sobre a estabilização de solos}

O solo é um dos componentes mais importantes na indústria da construção civil, uma vez que é parte integrante dos processos construtivos em vários tipos de obras: fundações, escavações, pavimentação, material de construção para aterros, etc. Em seu estado natural, é um material complexo e variável de acordo com uma série de fatores de origem: intemperismo, rocha mãe, localização, etc.

Quanto às suas características, é frequente encontrar uma variedade de solos naturais que não cumprem, total ou parcialmente, os requisitos necessários para determinada função a que se destinam. Como possíveis soluções para corrigir esse requisito destacam-se (Lambe e Whitman, 1969):

a) abandonar o local e optar por outro com solo apropriado;

b) eliminar o solo indesejado e substituí-lo por outro com características adequadas;

c) adaptar o projeto às condições existentes;

d) modificar as propriedades do solo para melhorar seu comportamento, segundo os padrões da engenharia.

Considerando fatores de ordem técnica, econômica e ambiental, os três primeiros requisitos citados no parágrafo anterior podem tornar-se menos atrativos. Assim, a solução de modificar as propriedades do solo para melhorar o seu comportamento pode ser um atrativo, principalmente, para solo que não atendem aos requisitos mínimos para a função desempenhada. Essa modificação é denominada estabilização ou melhoramento de solos.

Vargas (1977) considera estabilização de solos o processo que confere ao solo uma maior resistência estável às cargas ou desgaste ou à erosão, através da compactação, correção granulométrica e de sua plasticidade ou da adição de substâncias que lhe confiram uma coesão proveniente da cimentação ou aglutinação dos seus grãos. O processo de estabilização implica na modificação das 
propriedades do sistema solo-água-ar, de maneira a obter propriedades duradouras que devem ser compatíveis com uma aplicação particular (Oliveira, 1994).

Marangon (1992) descreve que a estabilização de solo, em um sentido geral, pode ser definida como sendo a alteração de qualquer de suas propriedades, de forma a melhorar o seu comportamento sob o ponto de vista de Engenharia. Consiste em um tratamento artificial, por um processo físico, químico ou físicoquímico, tornando o solo estável para os limites de sua utilização, e ainda fazendo com que esta estabilização permaneça sob a ação de cargas exteriores e também sob ações climáticas variáveis.

Castro et al. (2011) ressaltam o papel da estabilização in situ dos solos para viabilizar, técnica e economicamente, o aproveitamento dos materiais resultantes do processo de terraplanagem, buscando melhorar a qualidade dos materiais disponíveis e evitar desperdícios desnecessários de recursos energéticos e ambientais para a exploração de jazidas e transporte de materiais. De fato, o aproveitamento do solo existente no próprio local de obra, independentemente de suas características, apresenta vantagens de evitar a substituição dos materiais existentes por outro de melhor qualidade, como também evitar a necessidade de local de estocagem dos materiais de bota fora e consequente criação de danos ao meio ambiente.

Historicamente, o melhoramento de solos começou a ser utilizado para a construção de pavimentos rodoviários nas Civilizações Mesopotâmica e Romana, mas outros povos tinham recorrido esporadicamente ao emprego de cal para estabilização de solos (Hamzah, 1983, apud Cruz, 2004). Os gregos e romanos encarregaram-se de desenvolver a técnica de aplicação da cal para a estabilização de solos, uma vez que havia necessidade de obter superfícies rígidas para a circulação dos veículos com rodas, chegando a ser utilizado um outro material, a pozolana (cinza vulcânica), para melhorar a ação da cimentação da cal (Castro, 1930 apud Cruz, 2004).

Conforme consta na Associação Brasileira de Cimento Portland - ABCP (1958), a primeira tentativa do emprego do cimento Portland na estabilização de solos foi realizada em Salisbury Plain, Estados Unidos, em 1916, com o objetivo de possibilitar o tráfego de veículos de rodas não pneumáticas durante o inverno.

$\mathrm{Na}$ Europa, o despertar para a necessidade de estabilizar os solos surgiu na década de 30 e o grande impulso verificou-se no período pós $2^{\mathrm{a}}$ Guerra Mundial, na 
tentativa de dar resposta à grande necessidade de construção de estradas e pista de aeroportos, momento em que foi muito utilizada a estabilização com cimento (Hamzah, 1983 apud Cruz, 2004).

Castro (1981) descreve um histórico sobre a estabilização e, segundo o autor, em 1925, McCaustland relatou a utilização da cal hidratada para estabilização na América do Norte; em 1948, Aaron realizou o primeiro uso da cal na pavimentação, quando $2 \%$ de cal hidratada foi utilizada para reduzir o índice de plasticidade de um solo no Texas; em 1952, Levchanobskü sugeriu os seguintes teores ótimos de cal de acordo com o solo: argilo-arenoso e mecanicamente estável 4 a 5\%, solos argilosos e siltosos de textura média 6 a 7\% e para aqueles altamente argilosos de 7 a $8 \%$ de cal; em 1958, Handy apresentou um dos primeiros trabalhos utilizando o cimento Portland.

De acordo como que descreve Castro (1981), nas décadas de 60 e 70 muitos trabalhos foram publicados sobre a estabilização de solos para explicar tal efeito (Diamond e Kinter, 1965; Croft, 1967; Ingles, 1970; Stocker, 1972).

Os pavimentos com base e sub-base de solo-cimento são empregados no Brasil desde 1939, quando foi construída a estrada Caxambu (MG) - Areias (SP), no qual a ABCP juntou-se ao DNER (ABCP, 2009). Segundo Senço (2001), a primeira experiência de campo utilizando solo-cimento data dos anos 40, em que foi executado o acesso ao aeroporto de Bauru, em São Paulo, num trecho de $500 \mathrm{~m}$ de extensão; acesso ao aeroporto de Presidente Prudente, também em São Paulo, com extensão de $14 \mathrm{~km}$. A partir de então o solo-cimento passou a ser a base e a sub-base mais construída do estado de São Paulo, representando mais de 50\% da extensão de toda a rede pavimentada.

\section{2 \\ Métodos de estabilização de solos}

A estabilização de solos para utilização em pavimentos, seja em sub-base ou base, tem se mostrado bastante eficiente à medida que as exigências da qualidade construtiva são crescentes, além das exigências no quesito durabilidade. De fato, se os solos naturais, que cumprem os requisitos necessários para determinada função a que se destinam, estão escassos e muitas vezes distantes dos pontos de utilização tornando-se economicamente inviáveis, a estabilização de solos surge como uma 
opção viável, principalmente, no que diz respeito aos aspectos econômico, técnico e ambiental.

Oliveira (1994) descreve os seguintes objetivos visados pela estabilização:

- alcançar melhores características mecânicas: melhorando as resistências à compressão seca e molhada, a resistência à tração e ao cisalhamento;

- melhorar a coesão;

- reduzir a porosidade e as variações de volume: retração e expansão devido à ação da água.

E para atingir esses objetivos, existem os procedimentos básicos de estabilização mecânica e química.

\subsection{1}

\section{Estabilização mecânica}

A estabilização mecânica de um solo consiste em um conjunto de operações mecânicas que modificam o arranjo das partículas do solo ou sua granulometria por meio da subtração ou adição de algumas frações (Cristelo, 2001). Para Cruz (2004), esse método de estabilização engloba diversos processos com o mesmo objetivo: diminuição da quantidade de vazios existentes nos solos. Consequentemente, essa estabilização traz melhorias nas características do solo. As técnicas podem ser por compactação e por correção granulométrica.

A compactação é um processo mecânico que visa o aumento da compacidade do solo por meio da redução de volume do ar, conseguida à custa da aplicação de repetidas cargas (Fernandes, 2011). Essa ação mecânica provoca no solo uma diminuição no índice de vazios, melhorando as propriedades por aumento da resistência, diminuição da permeabilidade e deformabilidade.

A estabilidade por correção granulométrica pode ser conseguida pela adequada distribuição das diversas porções de diâmetro dos grãos. Senço (2001) explica que os vazios dos grãos maiores são preenchidos pelos grãos médios, e os vazios desses, pelos miúdos. Assim, a estrutura densa representa um produto de massa específica aparente superior à dos componentes, o que lhe dá maior resistência e impermeabilidade.

Pela correção granulométrica é possível estabilizar solos coesivos de baixa resistência através da adição de material de maior granulometria e para solos 
arenosos, devido à ausência de partículas cimentantes, através da adição de material fino. Yoder e Witczak (1975) citados por Bernucci et al. (2006) subdivide os solosagregados em três tipos distintos, dependendo da proporção relativa entre a parte graúda e a parte fina, conforme indicado na Figura 2.1. Os autores descrevem que em:

(a)

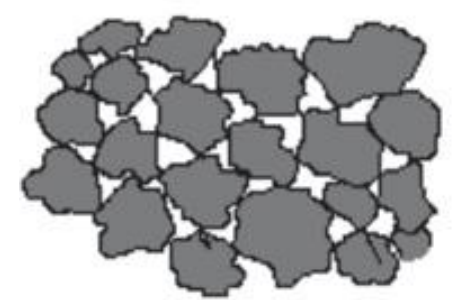

(b)

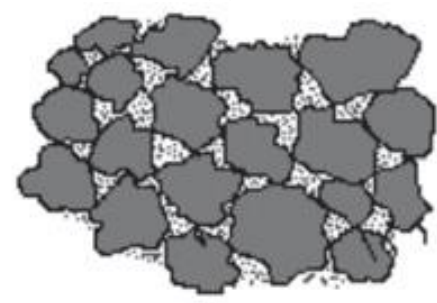

(c)

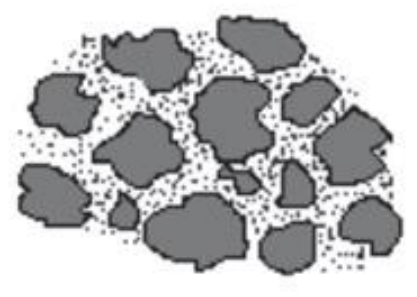

Figura 2.1 Tipos de solo-agregados (Yoder e Witczak, 1975 apud Bernucci et al., 2007).

(a) contato grão-grão; baixa densidade, permeável, não suscetível a mudanças com a umidade ou com o congelamento; compactação em geral difícil;

(b) os finos preenchem os vazios, proporcionando alta densidade, permeabilidade mais baixa em relação à configuração mostrada em (a), contato grão-grão, mais resistente que o tipo (a), menor deformabilidade; moderadamente difícil de compactar;

(c) a matriz de finos, não se garante contato grão-grão devido ao excesso de finos, densidade mais baixa em geral que a configuração apresentada em (b), permeabilidade menor que o tipo (b), podendo ser mesmo impermeável, dependendo da natureza dos finos; a mistura é afetada por variações de umidade, facilidade na compactação.

\subsection{2}

\section{Estabilização química}

A estabilização química tem como base as reações químicas que englobam um apreciável número de processos entre as partículas de solo, a água e os agentes estabilizadores. Dessa forma, é possível obter um solo com características melhores do que o solo puro.

A técnica da estabilização com aditivos químicos é amplamente usada na construção de estradas, aeroportos, aterros, revestimentos de canal, através da mistura de produtos químicos com o solo argiloso para melhorar as características 
da trabalhabilidade, resistência, rigidez, expansão e a capacidade de suporte. Nessa estabilização, as melhorias das propriedades do solo geralmente ocorrem por meio da formação química do gel e ligações entre as partículas do solo, juntamente com uma redução nas características de afinidade com a água (Puppala, 2016).

$\mathrm{Na}$ escolha do aditivo estabilizante de solo deve-se considerar o tipo de solo a que se destina a estabilização, resistência, durabilidade, custo, condições ambientais. Segundo os efeitos que os agentes estabilizadores produzem, pode-se classificá-los em: aglutinantes, que atuam cimentando as partículas de solo, e impermeabilizantes, que mantém os solos com um baixo teor de água (Sherwood, 1993 apud Cruz, 2004).

Ainda segundo este autor, o agente estabilizador deve possuir, de modo a garantir a sua viabilidade, as seguintes propriedades:

- adequação para uma larga variedade de solos;

- efeito estabilizador permanente;

- disponibilidade a baixo preço e em grande quantidade;

- não apresentar problemas quanto ao transporte e armazenamento;

- $\quad$ serem relativamente não tóxicos e não corrosivos.

Por meio dessa técnica de estabilização é possível empregar solos locais que, devido a sua baixa qualidade não poderiam ser utilizados isoladamente, pois não se adequariam ao exigido pelas especificações para a construção de bases e sub-bases. Além disso, o uso de solos estabilizados em vez de agregados naturais, cada vez mais escassos, pode ter consideráveis vantagens ambientais e econômicas (Sherwood, 1993 apud Cruz, 2004).

Sherwood (1993), citado por Cruz e Jalali (2010) descreve os seguintes benefícios do ponto de vista ambiental, econômico e de segurança em relação à estabilização química:

- minimização da perda de material ocasionada pela erosão e pelo tráfego nas estradas de terra;

- redução dos custos de compra, transporte e distribuição de agregados;

- redução dos materiais superficiais soltos;

- minimização da agressão ambiental causada pela instalação de pedreiras e britagem; 
- redução do uso de combustíveis associado às frequentes manutenções rodoviárias;

- resguardo das jazidas de bons materiais para usos mais nobres.

Sabendo-se que o solo é bastante variável nos aspectos físico e químico, a ação dos agentes estabilizantes pode ser mais ou menos efetiva. A Figura 2.2 apresenta os agentes mais adequados, mediante os resultados de ensaios de análise granulométrica e dos limites de Atterberg.

A partir da análise da Figura 2.2, observa-se que a estabilização química com cal e betume tem um campo de aplicação mais reduzido, o mesmo não acontece com o cimento Portland, que é adequado a todos os tipos de solos, e constitui uma aplicação mais generalizada para melhorar o comportamento do solo.

Ingles e Metcalf (1973) citados por Marangon (1992) salientam que em termos técnicos não se pode afirmar que um método de estabilização seja melhor que outro, sendo mais provável que certos métodos sejam mais econômicos e se adaptem às condições ambientais de cada lugar.

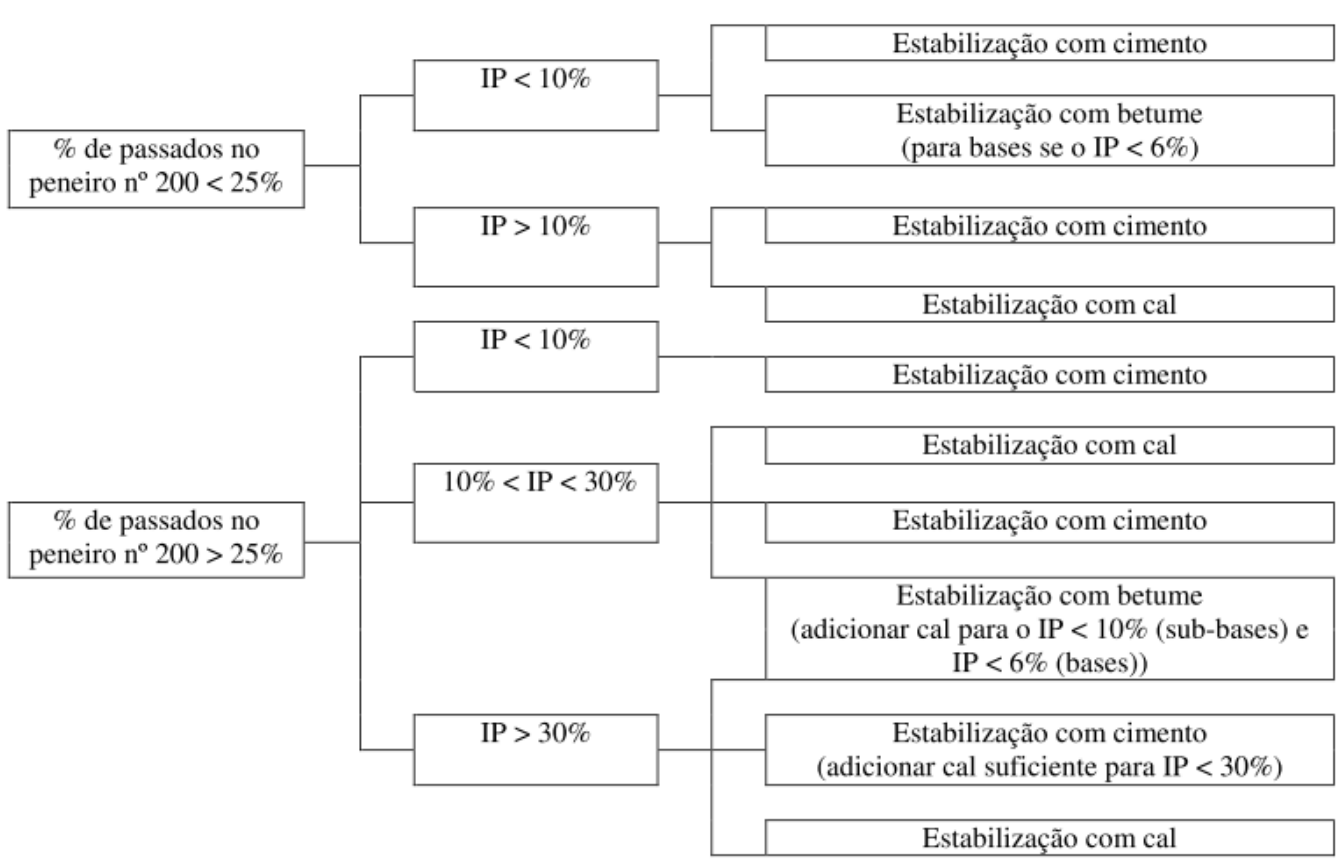

Figura 2.2 Agente estabilizante em função do tipo do tipo de solo (Little, 1995 apud Cruz e Jalali, 2010).

Além do cimento, cal e betume (emulsão asfáltica e alcatrões), outros produtos químicos podem ser utilizados como agentes estabilizantes: produtos de 
escória de alto forno (cinza volante), ácido fosfórico, cloreto de cálcio e de sódio, sulfato de lignina (Marangon, 1992).

(a) Estabilização com cal

A cal é um aglomerante obtido através da calcinação de rochas carbonatadas constituídas em sua maioria de carbonato de cálcio e/ou carbonato de cálcio e magnésio. A cal virgem ou cal viva resulta da calcinação dos carbonatos de cálcio e de cálcio-magnésio, que são o óxido de cálcio $(\mathrm{CaO})$ e o cálcio-magnésio (CaO.MgO) (Guimarães, 2002).

A partir do carbonato de cálcio $\left(\mathrm{CaCO}_{3}\right)$, também chamado de calcário, por meio da calcinação, transforma-se em óxido de cálcio $(\mathrm{CaO})$ e libera anidro carbônico, dando origem à chamada cal cálcica, segundo a reação:

$$
\mathrm{CaCO}_{3}+\text { calor } \rightarrow \mathrm{CaO}+\mathrm{CO}_{2}
$$

A mesma reação ocorre com o calcário dolomítico, que a partir da rocha contendo carbonato de magnésio $\left(\mathrm{MgCO}_{3}\right)$ origina-se a cal dolomítica $(\mathrm{CaO} . \mathrm{MgO})$, segundo a reação:

$$
\mathrm{CaCO}_{3} \cdot \mathrm{MgCO}_{3}+\text { calor } \rightarrow \mathrm{CaO} \cdot \mathrm{MgO}+\mathrm{CO}_{2}
$$

Ambas as cales, cálcica e dolomítica, são designadas de cal viva e esta pode reagir com água, liberando calor e produzindo a cal hidratada, segundo as reações:

$$
\begin{gathered}
\mathrm{CaO}+\mathrm{H}_{2} \mathrm{O} \rightarrow \mathrm{Ca}(\mathrm{OH})_{2}+\text { calor } \\
\mathrm{CaO} \cdot \mathrm{MgO}+\mathrm{H}_{2} \mathrm{O} \rightarrow \mathrm{Ca}(\mathrm{OH})_{2} \cdot \mathrm{MgO} \text { ou Ca}(\mathrm{OH})_{2} \cdot \mathrm{Mg}(\mathrm{OH})_{2}+\text { calor }
\end{gathered}
$$

Segundo o autor citado, a cal hidratada encontra-se na forma de pó seco ou com aspecto de creme, lama, leite ou solução saturada, dependendo da quantidade de água na reação.

A estabilização com cal é utilizada em solos instáveis, alterando as propriedades de engenharia pela melhoria da resistência, resistência à fratura, fadiga, deformação permanente, melhoria nas propriedades resilientes, redução na expansão (Puppala, 2016). O uso da cal na estabilização de solos visa atender a dois casos distintos (Senço, 2001):

I - melhoria da qualidade do solo - nesse caso o solo é recuperado, uma vez que não apresenta características tecnológicas ou econômicas para ser estabilizado, permitindo, dessa forma, a utilização do solo na estabilização com outros aditivos. 
II - estabilização direta do solo com o uso da cal - nesse caso, far-se-á mistura solo-cal para atender às condições exigidas para uma das camadas inferiores do pavimento.

Para Little (1995), as propriedades físicas mais importantes da cal relacionadas à estabilização de solo são: densidade, massa específica, tamanho das partículas, calor da reação e solubilidade. Já as propriedades químicas são: pH e velocidade da reação da solução cal-água, reação do $\mathrm{CO}_{2}$ com a cal, reação com a sílica e alumínio.

A adição de cal a um solo dá origem a uma série de reações (Guimarães, 2002): troca ou permuta iônica, floculação, cimentação e carbonatação. No entanto, essas reações não ocorrem simultaneamente, há a fase rápida com reações de troca iônica e floculação e a fase lenta, em que ocorre a cimentação e proporciona aumento da resistência, e a carbonatação, que é uma reação prejudicial (Lovato, 2004).

Quando a cal é combinada com a água na presença de sílica e alumina presente na argila, ocorrem reações químicas resultando na formação de novos compostos. Durante esta reação, a função primária da cal é alterar a estrutura das partículas e aumentar a resistência à contração-expansão e a susceptibilidade à água. Um resultado posterior resulta em um aumento na resistência atribuído à ligação das partículas através da formação do gel tobermorita que resulta no endurecimento do solo tratado (Puppala, 2016)

As partículas de argila estão carregadas eletricamente com predomínio de cargas negativas distribuídas nas faces, enquanto as cargas positivas posicionam-se em maioria nos bordos. Os cátions bivalentes $\mathrm{Ca}^{2+}$, proveniente da cal adicionada ao solo, vão substituir os cátions monovalentes $\left(\mathrm{Li}^{+}, \mathrm{H}^{+}, \mathrm{NH}_{4}{ }^{+}, \mathrm{Na}^{+}, \mathrm{K}^{+}\right)$até então adsorvidos nas duplas camadas iônicas. Essa troca diminui as forças repulsivas entre as partículas, uma vez que se verifica uma diminuição da carga negativa à medida que os cátions $\mathrm{Ca}^{2+}$ são adsorvidos pela superfície das partículas. Agora, as forças de atração resultam em floculação das partículas e os efeitos consistem em redução do índice de plasticidade e do limite de expansividade, redução densidade máxima. As partículas de argila comportam-se como um solo siltoso (Cristelo, 2004).

A introdução de cal no solo provoca uma mudança na textura da mistura, quando as partículas de argila permitem uma aproximação entre elas devido à 
redução no tamanho da camada de água ocorrendo uma atração face-aresta ou floculação. Essa floculação é ainda melhorada dada a concentração eletrolítica e o elevado pH existente no sistema cal-solo-água (Little, 1995).

Ainda de acordo com este autor, o resultado da troca catiônica e da floculação ou aglomeração das partículas são:

- redução substancial no tamanho e estabilização da camada de água adsorvida;

- aumento do atrito interno entre os aglomerados e maior resistência ao cisalhamento dos agregados;

- melhor trabalhabilidade devido à mudança na plasticidade da argila.

Diamond e Kinter (1965), citados por Castro (1981), admitiram os efeitos a curto prazo, ou seja, redução da plasticidade, das variações volumétricas, da granulometria, etc. são devido às reações nos contatos entre as partículas argila/cal, que ocorrem entre os grupos $-\mathrm{Al}(\mathrm{OH}) \mathrm{x}$, expostos nas arestas das partículas, os grupos $\equiv \mathrm{Si}-\mathrm{OH}$, presentes nas arestas e superfícies basais das partículas de argila e a cal adsorvida nas faces das partículas adjacentes ou simplesmente com a cal em contato direto, dando lugar a formação rápida de aluminatos e mais lenta de silicatos cálcicos hidratados.

Para as reações de cimentação (ou reações pozolânicas), os argilominerais caracterizam-se por serem pozolanas naturais, isto é, possuem constituintes passíveis de reagirem com a $\mathrm{Ca}(\mathrm{OH})_{2}$ para formar, em presença da água, novos compostos estáveis de poder endurecedor, semelhante aos produtos da pasta de cimento. Nesta etapa, as reações se processam lentamente, dado que a cal disponível tem que se difundir através da estrutura do solo e remover a sílica das partículas argilosas, conduzindo ganhos de resistência (Cristelo, 2004). Alguns fatores influenciam essas reações pozolânicas do solo-cal: grau de intemperismo, $\mathrm{pH}$ do solo, concentração de cátions, de sílico-alumínio, matéria orgânica no solo e o conteúdo de sulfatos solúveis do solo (Little, 1995).

Segundo Cristelo (2004), as reações pozolânicas podem ser resumidas da seguinte forma: a adição da cal eleva o pH, facilitando a dissolução da sílica e alumina dos argilominerais, reagindo com o cálcio e formando o silicato hidratado de cálcio e aluminato hidratado de cálcio, como descrito nas reações abaixo:

$$
\begin{gathered}
\mathrm{Ca}^{2+}+2(\mathrm{OH})^{-}+\mathrm{SiO}_{2} \rightarrow \mathrm{CaO}+\mathrm{SiO}_{2}+\mathrm{H}_{2} \mathrm{O} \\
\mathrm{Ca}^{2+}+2(\mathrm{OH})^{-}+\mathrm{Al}_{2} \mathrm{O}_{3} \rightarrow \mathrm{CaO}+\mathrm{Al}_{2} \mathrm{O}_{3}+\mathrm{H}_{2} \mathrm{O}
\end{gathered}
$$


Esses silicatos e aluminatos de cálcio originam um gel insolúvel em água que, após cristalização, leva à cimentação das partículas entre si (Figura 2.3).

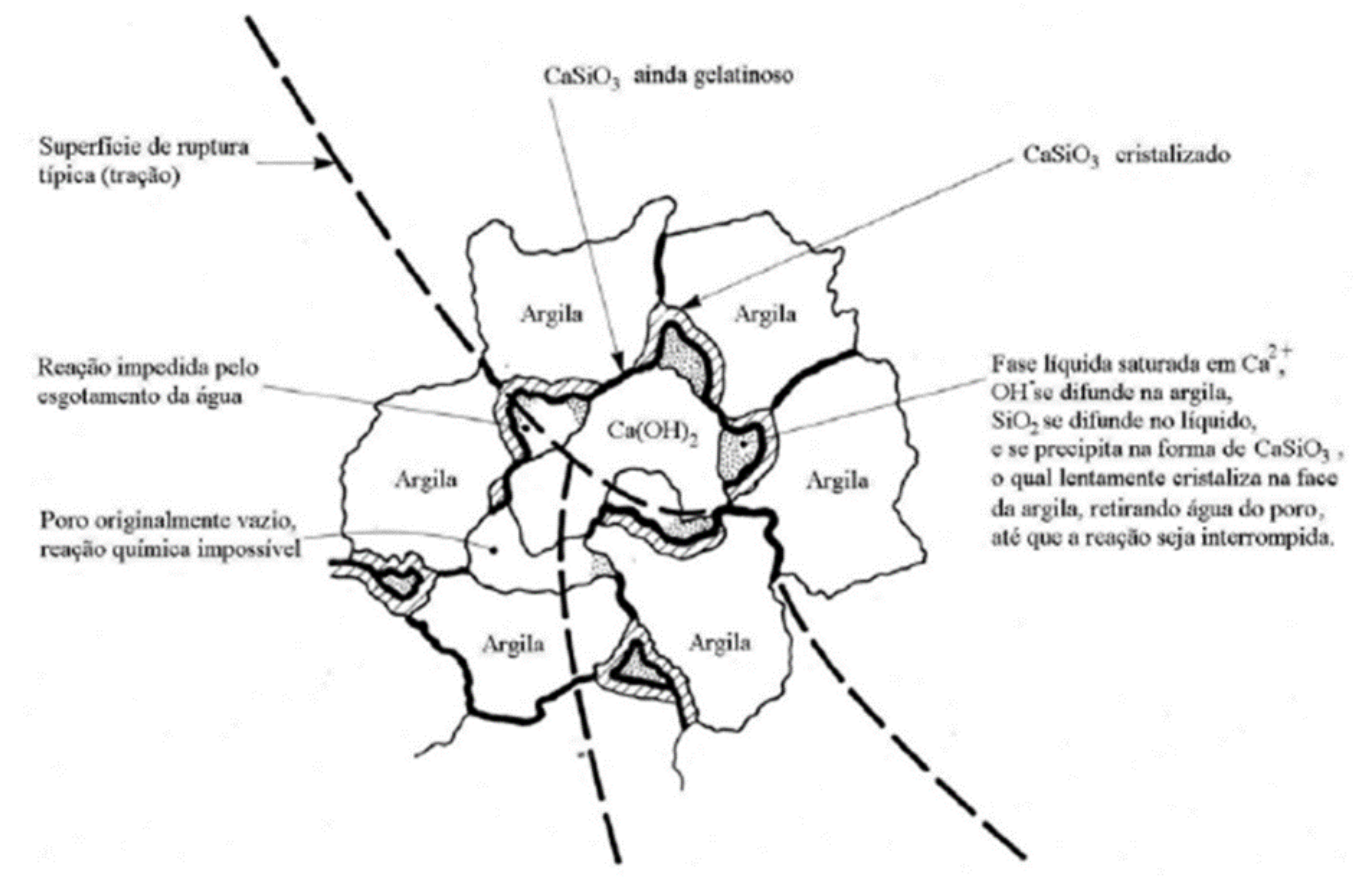

Figura 2.3 Mecanismos de estabilização solo-cal (Inglês e Metcalf, 1972 apud Lopes, 2011).

A carbonatação consiste em uma reação inversa à verificada na formação da cal viva, isto é, se esta permanece exposta ao ar durante um determinado período, reage com o $\mathrm{CO}_{2}$ e reverte ao carbonato de cálcio. Essa reação inversa depende da exposição ao ar da mistura ou existência do dióxido de carbono no seu interior e da disponibilidade de alguma cal que ainda não tinha reagido com as partículas de solo. Portanto, a carbonatação se constitui em uma reação prejudicial, uma vez que reduz a quantidade de cal disponível para reagir com o solo. Além disso, o carbonato de cálcio resultante forma uma cimentação fraca, prejudicando as reações pozolânicas, e possui elevada plasticidade (Cristelo, 2004).

A mistura da cal ao solo conduz alterações nas características de plasticidade e expansibilidade, granulometria, compactação, expansão, permeabilidade, resistência e durabilidade dessa mistura que, mediante as reações apresentadas, normalmente depende do tipo do solo (granulometria e mineralogia das partículas), tipo e teor de cal, teor de água e densidade, temperatura e tempo de cura.

A adição da cal ao solo provoca mudanças na plasticidade mais especificamente nos solos mais plásticos ou expansivos. Há uma redução no índice de plasticidade motivada pelo aumento do limite de plasticidade e pela redução do 
limite de liquidez (Cristelo, 2001). Essa variação de plasticidade pode ser entendida a partir das reações de permuta iônica, dado que quando os cátions trocáveis são o $\mathrm{Ca}^{2+}$ ou o $\mathrm{Mg}^{2+}$, a argila requer mais água (Gomes, 1986).

De acordo com Castro (1970), citado por Cruz (2004), as variações volumétricas sofridas pelas argilas quando sujeitas à um teor de água são significativamente reduzidas pela adição da cal. Esse estabilizante provoca um aumento no limite de retração, o que significa que as misturas solo-cal podem absorver mais água sem sofrer expansão quando em comparação ao solo não tratado.

A cal afeta a granulometria dos solos devido à floculação e aglomeração das partículas finas, tendo pouca importância nos solos mais granulares. As partículas finas aglomeradas fazem deslocar a curva granulométrica, o que pode ser significativo em solos com elevada porcentagem da fração argilosa, conforme descreve Castro (1970) citado por Cruz (2004).

Com base em estudos com dois tipos de solos, Portelinha et al. (2012) concluíram que os baixos teores de cal provocam variações significativas na composição granulométrica de um solo A-7-5 diferentemente dos resultados apresentados por um solo A-2-4. A presença de íons de cálcio, proporcional ao teor de cal na mistura, aumenta a capacidade de troca catiônica dos solos que foram responsáveis pelas modificações nos valores do índice de plasticidade, constituição granulométrica e pH dos solos. A adição de cal em ambos os solos foi mais efetiva na queda instantânea de sua plasticidade. Vale salientar que o solo A-7-5 apresenta uma porcentagem maior da fração argila, a qual consiste na parte ativa, participando, praticamente, de todas as reações físico-químicas que ocorre no solo.

Segundo Cristelo (2001) se a uma mistura solo-cal for dado tempo necessário para curar e ganhar resistência, antes da sua compactação, podem ser observadas posteriores reduções na massa específica seca máxima e incrementos de elevação na umidade ótima. Isto porque essa mistura não se limita a ser mais resistente e menos plástica do que o solo original, mas é também menos densa e responde de forma diferente à umidade. A resistência aumenta com a quantidade de cal adicionada até um valor ótimo, enquanto que a densidade máxima diminui em proporção inversa, indicando que a perda de resistência devido à diminuição da densidade é mais do que compensada pela cimentação pozolânica dada pelas reações entre o solo e a cal. 
De acordo com Puppala (2016), as propriedades das misturas de solo e cal dependem, principalmente, do tipo de solo, período e processo de cura, construção no campo e quantidade relativa de cal utilizada na estabilização. Em estudos de durabilidade apresentados pelo autor, argilas contendo argilomineral montmorilonita diminui a eficiência na estabilização. Para um solo com $20 \%$ de montmorilonita e ilita, tratado com 6\% de cal, o corpo de prova resistiu a 21 ciclos de molhagem e secagem. Para um solo com $40 \%$ de montmorilonita, o corpo de prova não resistiu aos 21 ciclos.

Fonseca e Neves (2011) apresentam as seguintes conclusões extraídas de estudos com misturas de cal viva em três distintos solos portugueses: alterações imediatas das características físicas (granulometria, plasticidade e trabalhabilidade); ganho de rigidez e resistência e redução na permeabilidade; aumento de temperatura acelera as reações químicas que influenciam as condições de cura no desenvolvimento das resistências mecânicas. Por meio de ensaios triaxiais, os autores observaram uma acentuada resistência de pico e dilatância, e posteriormente uma resistência residual, comportamento típico de solos muito sobreadensados ou com forte ligação entre as partículas; aumento do intercepto coesivo e diminuição da permeabilidade a curto prazo e, em maior ordem de grandeza, a logo prazo.

(b) Estabilização com solo-emulsão

Denomina-se estabilização betuminosa aqueles métodos de construção em que um material betuminoso é adicionado a um solo, ou mistura de solos, visando a melhoria de suas características (Senço, 2001). Esse tipo de estabilização começou a ser empregada quando engenheiros rodoviários, trabalhando nas proximidades de campos petrolíferos, notaram que o espalhamento de óleo cru sobre as estradas de terra reduzia o pó existente, tornando-as mais aptas a resistirem aos rigores do tráfego e do intemperismo.

A estabilização de um solo com emulsão asfáltica depende fundamentalmente da composição granulométrica e das características físico-química do mesmo (ABEDA, 2001):

I - quando usado em solos granulares a função do ligante é aglutinadora, ou seja, conferir ao solo uma ação coesiva; 
II - quando usado em solos argilosos a função do ligante é proteger as partículas de argila da ação da umidade, isto é, a emulsão atua promovendo a impermeabilização do solo, cobrindo as partículas de argila com uma fina camada de betume fortemente aderida e bloqueando os condutos capilares, afim de impedir o acesso da água.

Segundo Bernucci et al. (2006) uma emulsão é definida como uma dispersão de dois ou mais líquidos imiscíveis, que no caso da emulsão asfáltica esses líquidos são o asfalto e a água. Para manter essa emulsão estável é necessária a utilização de um produto auxiliar, uma vez que os dois materiais (óleo e água) não formam uma emulsão por simples mistura. Esses produtos são agentes emulsionantes ou emulsificantes que reduz a tensão superficial permitindo que os glóbulos de asfalto permaneçam em suspensão na água por algum tempo (semanas ou meses, a depender da formulação da emulsão) e evitando a aproximação entre as partículas e sua posterior coalescência.

De acordo com Kézdi e Rétháti (1988), citado por Jacintho (2005), quando se mistura água e betume a um solo, inicia-se uma série de processos físicos e químicos que irão influenciar no seu comportamento mecânico. Ainda segundo os autores, o objetivo da estabilização com material asfáltico é cobrir as partículas individuais em um filme betuminoso que deve ser, por um lado, esbelto bastante para não reduzir radicalmente a resistência por atrito e, por outro lado, espesso bastante para cimentar os sólidos (Figura 2.4).

A partir de estudos termodinâmicos, Guarçoni et al. (1988) e Mattos (1991) consideram o sistema solo-betume-água como um sistema fechado ${ }^{1}$, heterogêneo ${ }^{2}$, constituído por três fases e quatro componentes. Das três fases, uma é contínua, isto é, constituída pela solução aquosa obtida pela adição de água a fase aquosa da emulsão, e duas fases são descontínuas, isto é, fases constituídas pelo solo e pelos glóbulos de betume. Assim, as interfaces do sistema são: solo-solução aquosa; solobetume e betume-solução aquosa.

\footnotetext{
${ }^{1} \mathrm{O}$ sistema foi considerado fechado por não haver troca de massa com o exterior.

${ }^{2} \mathrm{O}$ sistema heterogêneo é aquele constituído de dois ou mais subsistemas homogêneos, limitados entre si por superfícies bem definidas (interfaces) nos quais se verificam variações bruscas de propriedades.
} 


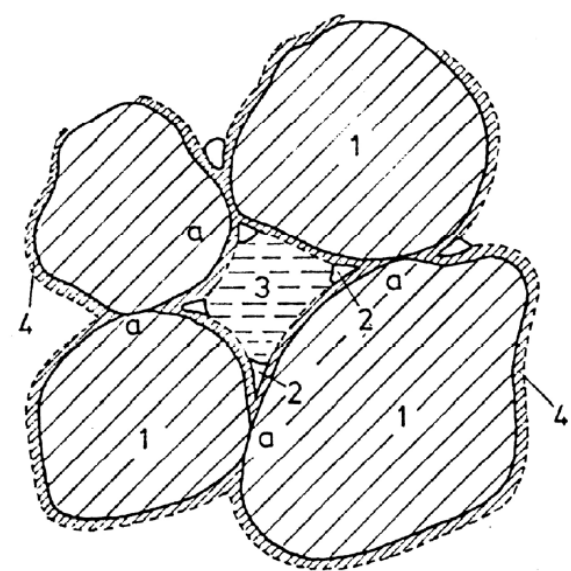

1 - grão de solo

2 - vazios de ar

3 - água intergranular

4 - filme betuminoso

a - contato entre os grãos

Figura 2.4 Distribuição do filme betuminoso na massa de solo (Kézdi, 1979 apud Miceli Jr., 2006).

$\mathrm{Na}$ interface solo-solução aquosa tem-se um subsistema composto pelo solo e pela solução aquosa, sendo esta constituída por solvente e um soluto tensio-ativo (emulsificante). Neste caso, o solo caracteriza-se por ser uma substância adsorvente e a substância tensio-ativa, com características de adsorvato. Essas condições vão promover o fenômeno de adsorção, ou seja, uma variação da concentração de adsorvato na interface solo-solução aquosa. Existe, portanto, aumento de massa na fase solo, uma vez que há um aumento de concentração do adsorvato na superfície dos grãos de solo, com consequente diminuição da concentração do adsorvato na solução aquosa. Em vista disto, os subsistemas são abertos ${ }^{3}$.

Quando os grãos de solo entram em contato com a solução aquosa adsorverão parte do soluto tensio-ativo da fase líquida da emulsão, provocando uma queda na concentração deste soluto na solução aquosa. Essa diminuição da concentração do soluto produzirá um desequilíbrio na emulsão devido ao aumento da tensão superficial da fase líquida, o que dará origem a ruptura da emulsão e consequente formação de aglomerado de partículas betuminosas. A quantidade de soluto adsorvido é função de sua concentração na solução, e isto explica porque é mais fácil se misturar solo com emulsão quando se tem solução aquosa bem diluída, o que é conseguido pela diluição da emulsão e/ou pela adição prévia de água no solo.

Ainda de acordo com Guarçoni et al. (1988) e Mattos (1991), o sistema soloemulsão-água quando confinado e compactado dará origem a outro formado por uma estrutura de grãos de solo com adsorção superficial do soluto tensio-ativo, e

\footnotetext{
${ }^{3}$ No sistema aberto há troca de matéria com a vizinhança; sua massa é variável. No entanto, o sistema principal é fechado como foi considerado o sistema solo-betume-água e apenas aberto nos subsistemas.
} 
ainda com grumos formados pelo ligante betuminoso, funcionando como rótulas, as quais diminuem o número de pontos de contato grão-grão, acarretando uma diminuição na resistência do conjunto aos esforços cisalhantes. Esses grumos funcionam também como elementos obturadores da rede de capilares criada pela estrutura dos grãos de solo formado após a compactação.

Caso o sistema obtido por mistura e compactação for submetido ao processo de perda de umidade a níveis bem baixos e levado novamente o sistema a reabsorver água até a saturação, verifica-se que a quantidade de água absorvida será realmente menor que a água absorvida pelo mesmo solo compactado sem emulsão. Assim, a ação hidrófuga, que foi criada pela adsorção de soluto tensio-ativo no solo e pela obturação da rede de capilares, causada pelas partículas de betume, irá aumentar a resistência do sistema, dado o menor teor de umidade. Enquanto o sistema multirotulado tenderá a diminuir a resistência (Mattos 1991).

Kézdi (1979), citado por Miceli Jr. (2006), com base no estabilômetro de Hveem, confirmou um teor de emulsão em que a resistência ao cisalhamento é ótima e máxima e varia com o tipo de solo. Um acréscimo nesse teor ótimo, o filme de emulsão envolvente da partícula de solo se torna espesso demais, fazendo o papel de rótula e, consequentemente, diminuindo o atrito entre os grãos. Assim, com teores altos de emulsão pode-se até encontrar valores de resistência menores que os do solo puro.

O processo de estabilização de solo com emulsão é influenciado pelos elementos componentes da mistura tais como: tipo de solo, teor de água, tipo de emulsão e pelos métodos utilizados na preparação da estabilização. Sant'Ana (2009) realizou extenso estudo com quatro solo do Estado do Maranhão e emulsão de ruptura lenta com fins de aplicação em pavimentos de vias de baixo volume de tráfego. Gondim (2008) avaliou a viabilidade da estabilização betuminosa de três solos do Estado de Ceará com emulsão de ruptura lenta, tendo a emulsão efeitos distintos para os vários tipos de solo.

Lima (2016), verificando as diferentes energias Proctor normal, intermediária e pela metodologia Marshall (75 golpes/face do corpo de prova) para estabilização de um solo (SP-SM) com emulsão asfáltica (RL-1C), concluiu que esta última promoveu aumento da massa específica aparente da mistura solo-emulsão, diminuição da porcentagem do volume de vazios na estrutura compactada da mistura e redução da percentagem de volume de vazios em relação aos grãos 
minerais. Além de que, a metodologia Marshall associada ao aquecimento da mistura a $100^{\circ} \mathrm{C}$, apresentou melhores resultados finais de compactação das misturas confeccionados com elevados teores de emulsão asfáltica.

Santos (2009) analisou a viabilidade da estabilização solo-emulsão do tipo RL-1C com três solos (arenoso, argiloso e intermediário) comuns do estado de Sergipe. Os resultados dos ensaios (ISC, resistência à compressão simples, resistência à tração por compressão diamentral e módulo de resiliência) indicaram que a emulsão para estabilizar um solo depende do tipo de solo e das condições de cura da mistura. $\mathrm{O}$ autor concluiu que a quantidade de emulsão satisfatória para estabilizar o solo arenoso situou-se entre 4 e $6 \%$, maior do que os percentuais que promoveram a estabilização dos solos argilosos, neste caso, entre 2 e $4 \%$.

Jacintho et al. (2005) verificaram, a partir de análises micro-estruturais, uma maior integração da fração fina com a emulsão asfáltica, formando uma massa que se distribui ao redor das partículas de areia. Essa massa de argila mais asfalto deve, em princípio, promover um aumento da coesão e a redução da permeabilidade. Em síntese, os autores ainda concluem que tanto os resultados da compactação quanto os de resistência à compressão simples mostraram que a influência da emulsão no comportamento da mistura depende do tipo do solo, podendo aumentar ou reduzir o peso específico aparente seco, manter ou reduzir a umidade ótima, melhorar ou piorar a resistência à compressão simples.

(c) Estabilização com cinzas de carvão mineral

A queima do carvão mineral pulverizado na câmara de combustão de centrais termelétricas gera resíduos podendo ser denominado de cinza volante (Fly Ash), quando o resíduo é finamente dividido e arrastado pelos gases de exaustão, ou cinza de fundo (Bottom Ash), quando o resíduo se aglomera no fundo da câmara. A cinza volante possui propriedades pozolânicas que, de acordo com a ASTM C-51/2011, pozolana é um material silicoso ou sílico-aluminoso que por si só possui pouco ou nenhum valor cimentício, mas que finamente dividido e na presença de umidade reagirá quimicamente com os hidróxidos alcalinos e alcalinos-ferrosos, a temperatura ambiente, de modo a formar ou ajudar na formação de compostos com propriedades cimentantes.

A cinza volante tem pouca propriedade cimentante comparada com a cal e o cimento, não podendo, em sua maior parte, produzir o efeito desejado por si só. No 
entanto, na presença de uma pequena quantidade de ativador pode reagir quimicamente para formar um composto cimentício o qual contribui para melhorar a resistência do solo (Makusa, 2012).

Segundo Nardi (1975), os processos clássicos de estabilização de solos são, em geral, de difícil aplicação a solos mal graduados desprovidos de finos, como numa areia pura e uniforme. Isso porque a uniformidade das partículas do solo dificulta a cimentação devido ao maior volume de vazios e o menor número de contatos entre os grãos do solo. Solos arenosos com escassez de argilas coloidais, de acordo com Rosa (2009), não reagem satisfatoriamente com a cal, e a adição de cinza volante pode torná-lo reativo ao aditivo. Neste caso, a função da cinza volante é substituir a fração fina do solo, uma vez que pode reagir com a cal, embora o tamanho da cinza seja diferente do da argila, complementa o autor.

No mesmo raciocínio, Pinto (1971) descreve que a cinza volante é um agente efetivo na estabilização química de solos, pois um solo natural que não reage com a cal poder-se-á adicionar material pozolânico e a cimentação com a cal será garantida, verificando-se rapidamente a reação. Cal e cinza volante, em combinações, podem muitas vezes ser usadas com sucesso na estabilização de materiais granulares, desde que a cinza proporcione um agente com a qual a cal possa reagir (Departments of the Army, the Navy, and the Air Force, 1994).

Segundo Rohde et al. (2006) os elementos responsáveis pela atividade pozolânica nas cinzas volantes são $\mathrm{SiO}_{2}, \mathrm{Al}_{2} \mathrm{O}_{3}, \mathrm{Fe}_{2} \mathrm{O}_{3}, \mathrm{CaO}, \mathrm{MgO}, \mathrm{SO}_{3}, \mathrm{Na}_{2} \mathrm{O}$ e $\mathrm{K}_{2} \mathrm{O}$. Entretanto, o grau de reação é ainda dependente de outras variáveis como a distribuição do tamanho das partículas e mineralogia dos solos.

As propriedades físico-químicas da cinza de fundo também variam com a composição do carvão, o grau de moagem do beneficiamento na pré-queima e o sistema de extração e transporte da cinza após a queima (Gothe, 1990). A composição química desse tipo de cinza pode varia de 40 a $70 \%$ de sílica, de 15 a $30 \%$ de alumina e 2,0 a $14 \%$ de óxido de ferro, o que corresponde a aproximadamente $95 \%$ do total da composição. O restante é formado por outros óxidos, traços de outros metais (Farias, 2005). Em investigações dos constituintes de mais de 600 amostras de cinza nos EUA foi encontrado principalmente $\mathrm{SiO}_{2}$, $\mathrm{Fe}_{2} \mathrm{O}_{3}, \mathrm{Al}_{2} \mathrm{O}_{3}$ com pequenas quantidades de $\mathrm{CaO}, \mathrm{K}_{2} \mathrm{O}, \mathrm{Na}_{2} \mathrm{O}, \mathrm{MgO}, \mathrm{TiO}_{2}, \mathrm{P}_{2} \mathrm{O}_{5}$ e $\mathrm{SO}_{3}$. Em carvão betuminoso, os três maiores componentes $\left(\mathrm{SiO}_{2}, \mathrm{Fe}_{2} \mathrm{O}_{3}\right.$ e $\left.\mathrm{Al}_{2} \mathrm{O}_{3}\right)$ 
correspondem a $90 \%$ do total, enquanto as cinzas de linhito e sub-betuminoso tinham relativamente elevadas porcentagens de $\mathrm{CaO}, \mathrm{MgO}_{\text {e }} \mathrm{SO}_{3}$ (Kim et al., 2005).

ACAA (2003) lista algumas aplicações da cinza volante: com o cimento Portland para melhorar muitas propriedades do concreto, uma vez que o cimento possui muita cal livre que pode reagir quimicamente com a cinza; em base de pavimentos quando a cinza é combinada com a cal ou cimento Portland; como preenchimento fluido numa mistura de cinza volante, água e cimento Portland; como material de aterro; estabilização química e mecânica de solos; como material fino em camada de asfalto, aumentando a rigidez, melhorando a resistência e durabilidade; como rejuntes em que a cinza, água e outros materiais preenchem vazios no pavimento de concreto.

Quando são misturados solo ou agregado, cal, cinza volante e água ocorrem, em geral, dois tipos diferentes de reações. O primeiro tipo é aquela em que a cal age independentemente da cinza volante através da troca catiônica, floculação e a carbonatação. O segundo tipo ocorre entre a cal e a cinza volante (reações pozolânicas), num mecanismo que estabiliza o material através da formação de silicatos e aluminatos hidratados de cálcio (Marcon, 1977).

Esta reação pozolânica depende da solubilização da sílica, sendo sua ativação, pelos íons hidroxilas, apresentando um papel importante na formação dos silicatos hidratados. Algumas das reações possíveis que podem ocorrer numa mistura cal cinza volante - água, onde " $\mathrm{R}$ " representa $\mathrm{Ca}^{2+}$ ou $\mathrm{Mg}^{2+}$ ou combinação desses dois íons (Marcon, 1977):

$$
\begin{aligned}
& \mathrm{RO}+\mathrm{H}_{2} \mathrm{O} \rightarrow \mathrm{R}(\mathrm{OH})_{2} \\
& \mathrm{RO}+\mathrm{H}_{2} \mathrm{O}+\mathrm{CO}_{2} \rightarrow \mathrm{RCO}_{2}+\mathrm{H}_{2} \mathrm{O} \\
& \mathrm{R}(\mathrm{OH})_{2}+\mathrm{CO}_{2} \rightarrow \mathrm{RCO}_{2}+\mathrm{H}_{2} \mathrm{O} \\
& \mathrm{R}(\mathrm{OH})_{2}+\mathrm{SiO}_{2}+\mathrm{H}_{2} \mathrm{O} \rightarrow \mathrm{xRO} \cdot \mathrm{ySiO}_{2} \cdot \mathrm{zH}_{2} \mathrm{O} \\
& \mathrm{R}(\mathrm{OH})_{2}+\mathrm{Al}_{2} \mathrm{O} 3+\mathrm{H}_{2} \mathrm{O} \rightarrow \text { xRO.y } \mathrm{Al}_{2} \mathrm{O}_{3} \cdot \mathrm{zH}_{2} \mathrm{O} \\
& \mathrm{R}(\mathrm{OH})_{2}+\mathrm{Al}_{2} \mathrm{O} 3+\mathrm{SiO}_{2}+\mathrm{H}_{2} \mathrm{O} \rightarrow \mathrm{xRO} \cdot \mathrm{yAl}_{2} \mathrm{O}_{3} \cdot \mathrm{zSiO}_{2} \cdot \mathrm{wH}_{2} \mathrm{O} \\
& \mathrm{R}(\mathrm{OH})_{2}+\mathrm{SO}_{3}{ }^{2-}+\mathrm{Al}_{2} \mathrm{O}_{3}+\mathrm{H}_{2} \mathrm{O} \rightarrow \mathrm{xRO} \cdot \mathrm{yAl}_{2} \mathrm{O}_{3} \cdot \mathrm{zSO}_{4} \cdot \mathrm{wH}_{2} \mathrm{O}
\end{aligned}
$$

O material pozolânico presente na cinza volante pode reagir com a cal, pois esse material é constituído por sílica e alumina, com consequente cimentação das partículas. Segundo Herrin e Mitchell (1961) citado por Rosa (2009), quando a quantidade desejada de pozolana não estiver presente no solo, a adição de materiais 
pozolânicos, tais como a cinza volante, auxiliarão muitas vezes a produzir os níveis de reação desejados com a cal.

As propriedades dos materiais estabilizados pozolanicamente são influenciadas por diversos fatores seja de natureza do material empregado, suas proporções e processo de execução até a cura (Nardi, 1975). Pinto (1971) cita os fatores que, segundo Mateos (1961), afetam a estabilização dos solos representativos do estado de Iowa (EUA) com cinzas volantes obtidas de centrais elétricas da região, segundo Mateos (1961): tipo de cal, tipo de cinza, tipo de solo, efeito de diferentes proporções de cal e cinza, relações entre umidade, densidade e resistência, efeito da energia de compactação, efeito da temperatura de cura, a influência da adição de aditivos químicos, influência da demora de compactação depois da mistura umedecida, teste de congelamento e degelo, etc..

Nos estudos com misturas de cinza volante e cinza de fundo para aterros de estradas Kim et al. (2005) concluíram que o peso específico aparente seco máximo foi menor para as cinzas em comparação ao solo; a resistência ao cisalhamento da mistura com cinzas mostrou-se igual ou superior à resistência das areias compactadas na mesma energia; em ensaios triaxiais, as misturas de cinza, com 95\% de grau de compactação, exibiram comportamento similar aos solos arenosos em estado denso (i.e., comportamento dilatante), enquanto as cinzas compactadas a $90 \%$, o comportamento se assemelhava à areia em estado solto.

Yoon et al. (2002) consideram aceitável, após um ano de monitoramento instrumentado, um aterro construído com uma mistura de cinza volante e cinza de fundo, numa proporção 60:40, respectivamente. Consoli et al. (2001) observaram que a adição de cal de carbureto melhorou as propriedades de rigidez e resistência de uma areia siltosa. Entretanto, a presença de cinza volante foi fundamental para melhorar o comportamento do material, devido essencialmente à maior quantidade de reações pozolânicas.

Mallmann (1996) observou que o aumento da energia de moldagem dos corpos de prova de misturas solo-cinza-cal desenvolveu um acréscimo de resistência à compressão simples, provavelmente devido a um maior número de reações pozolânicas que se desenvolveram com a aproximação das partículas devido ao aumento da energia. Em média os acréscimos de resistência foram de 20 a 40\%, com cura em autoclaves, e de 5 a $25 \%$, com cura em câmara à temperatura constante. 
Ainda de acordo com Mallmann (1996), o fator temperatura de cura tem a finalidade acelerar as reações pozolânicas. Quando corpos de prova curados em autoclaves, com temperaturas variando de $149^{\circ} \mathrm{C}$ a $188^{\circ} \mathrm{C}$, obtiveram em média um acréscimo de resistência que variou de 30 a 60\%, em comparação às amostras curadas pelos processos de câmara à temperatura constante ao 7,14, 18 e 60 dias.

Lopes (2011) comprovou que misturas com solo A-2-4, cal e cinza de fundo e volante é benéfico não somente para o meio ambiente, como para a engenharia de pavimentos. Ensaios de módulo de resiliência indicaram que o tempo de cura tem influência para as misturas com a presença da cal, isto é, para maiores tempos de cura há possibilidade de obter melhores resultados. Em relação ao tipo e teor de cinzas, as cinzas volantes possuem maior capacidade de desenvolver, em conjunto com a cal, a estabilização química do solo e as cinzas de fundo favorecem a ocorrência da estabilização granulométrica. Quanto a deformação permanente, a autora concluiu que o tempo de cura influi de forma positiva, diminuindo os valores para as misturas analisadas, sendo a cinza volante apresentando maiores diminuições relativas do que a cinza de fundo.

Comparando os melhores resultados obtidos de Barros (2015) que trabalhou com solo A-2-4, 50\% e 100\% de cinza volante e 5\% de cal, ficou constatado que o CBR aumentou com o aumento do teor de cinza, o módulo de resiliência aumentou com a cura e a inserção da cal fez o comportamento da mistura depender mais da tensão desviadora do que a tensão de confinamento. A autora também verificou que o efeito do tempo de cura tem influência na resistência à compressão simples e na resistência à tração, sendo a mistura com $100 \%$ de cinza e 5\% de cal aquela de melhores resistências e esse aumento Barros (2015) atribuiu à ação cimentante da cal.

(d) Estabilização com cinzas de resíduos sólidos urbanos

A cinza de resíduos sólidos urbanos (RSU) também pode ser utilizada na estabilização de solo. No entanto, segundo Lopes (2011), as pesquisas sobre este tipo de resíduo com solo são recentes quando comparadas aos demais resíduos utilizados como agentes cimentantes e, pode-se dizer, que foram motivadas pelos mesmos princípios: reaproveitamento de resíduos, busca por materiais de construção não-convencionais e preservação de materiais naturais. 
Vizcarra (2010) descreve que as cinzas do RSU têm sido menos utilizadas e estudadas que as cinzas de carvão visto que a quantidade de usinas de resíduos urbanos é menor que aquelas que usam o carvão mineral. Em relação ao comportamento sobre os efeitos e mecanismos de estabilização, as cinzas do RSU são comparáveis aos da cinza de carvão, desde que aquelas contenham matéria orgânica (VIZCARRA, 2010).

Ferreira et al. (2003) identifica algumas possíveis aplicações das cinzas volantes de RSU: cimento, concreto, cerâmica, pavimentação, aterros, agricultura, etc. No caso de estradas, uma possibilidade é aplicação como um substituto da areia e/ou cimento em bases e sub-base estabilizadas com cimento. No entanto, questões ambientais relacionadas a este uso é a contaminação do solo abaixo e do lençol freático por substâncias lixiviadas da cinza. Os autores citam que, na Holanda, estudos com cinza volante de RSU após pré-lavagem seguida da cimentação satisfazem padrões ambientais daquele país para ser utilizado como material de construção, além de que o custo desta operação de lavagem é mais barato do que eliminar o resíduo como produto perigoso.

Goh e Tay (1993) relatam que esse tipo de cinza apresenta pré-requisitos para aplicação em aterros com alta resistência, permeabilidade típica de material granular e densidade quando compactada menor que os aterros convencionais. Essas cinzas poderiam ser usadas para estabilizar solos argilosos com um aumento de duas a três vezes a resistência do solo natural, além de, em combinação com o cimento e cal, requererem maiores ganhos de resistência, sugerem os autores. Ainda segundo esses autores, a lixiviação das amostras com cinza volante de RSU indicaram, inicialmente, traços de cádmio e cromo acima dos limites aceitáveis, mas após 28 dias de lixiviação, as concentrações caíram abaixo desses limites. As concentrações de metais pesados em lixiviados da cinza estabilizada com cimento e cal não foram detectadas.

Em estudos com cinzas de RSU da cidade do Rio de Janeiro com um solo A7-6, Vizcarra (2010) concluiu que é viável a utilização de cinzas como aditivo do solo para utilização em base de pavimentos de baixo volume de tráfego. $\mathrm{O}$ autor verificou que o comportamento resiliente tem influência do teor de cinza, teor de umidade, tempo para a compactação após a mistura dos materiais, tempo de cura e a adição de cinza aumentou a capacidade de suporte do solo e a adição de $40 \%$ de 
cinza volante reduziu a expansibilidade do solo até menos de $5 \%$, viabilizando o seu uso com base de pavimento.

\section{3}

\section{Estabilização de solo com cimento Portland}

\subsection{1}

\section{Considerações iniciais}

O cimento Portland pode ser usado quer para modificar e melhorar a qualidade do solo quer para transformar o solo numa massa cimentada com maior resistência e durabilidade. A quantidade desse estabilizante utilizado dependerá do fato de o solo ser modificado ou estabilizado (Departments of the Army, the Navy, and the Air Force, 1994).

$\mathrm{Na}$ literatura podem ser encontradas diferentes denominações da mistura de solo e cimento: solo estabilizado, solo melhorado, solo modificado, solo tratado. O critério para adoção de uma ou outra denominação é o grau de alteração das propriedades do solo natural em função da quantidade de cimento adicionado. Vale destacar que os processos são os mesmos, isto é, introdução e mistura de cimento Portland ao solo com o objetivo de obter propriedades adequadas a determinado uso na engenharia (Foppa, 2005).

Perante essas denominações far-se-á uma distinção segundo o DNIT (2006):

- solo-cimento: é uma mistura devidamente compactada de solo, cimento Portland e água que deve satisfazer a certos requisitos de densidade, durabilidade e resistência, dando como resultado um material duro, cimentado, de acentuada rigidez à flexão. O teor de cimento adotado usualmente é da ordem de 6 a 10\%;

- solo melhorado com cimento: é obtido com adição de pequenos teores de cimento, cerca de 2 a 4\%, visando primordialmente à modificação de solo no que se refere à sua plasticidade e sensibilidade à água.

O conceito de solo-cimento, segundo a PCA (2001), é uma mistura de solo e quantidades de cimento Portland e água, compactada a alta densidade.

Segundo a NBR-12253/1992, o solo-cimento é um produto endurecido resultante da cura de uma mistura íntima compactada de solo, cimento e água, em 
proporções estabelecidas através de dosagem, conforme este projeto, e executada de acordo com a NBR-12254.

Rodrigues (1992) descreve o solo-cimento como uma combinação, compactação e cura de uma mistura de solo e agregado, cimento Portland e água. O objetivo é formar um material endurecido com propriedades específicas de engenharia. Na mistura de solo-cimento, as partículas do solo e agregado são unidas pela pasta de cimento diferentemente da ligação da massa de concreto, uma vez que a partícula individual não é completamente revestida por essa pasta, cita o autor.

Para Concha (1986) na estabilização com cimento se desenvolvem reações químicas do cimento hidratado, no qual são desenvolvidos vínculos químicos entre a superfície dos grãos de cimento hidratado e a parte da partícula de solo em contato com o grão de cimento.

O uso da técnica da engenharia geotécnica, como a substituição de solos impróprios é muitas vezes problemática, não só por seus altos custos, mas ainda por razões ambientais, seja a inviabilidade de extrair solos distantes do local da obra ou de construir em solos de baixa capacidade de carga. A alternativa de melhorar o solo local com adição de cimento Portland pode ser uma excelente solução (Fonseca et al., 2009).

A estabilização de solo com cimento é uma maneira eficiente de reconstrução de pavimentos, uma vez que $90 \%$ do material já estão no local, reduzindo os custos com transporte, manuseio e conservando os materiais de alta qualidade para outros fins (PCA, 2014). Não é só em camadas de pavimento, mas o solo-cimento tem sido utilizado em camadas de base de fundação superficial, fundações profundas, reforço em aterros, proteção de encosta, contenção em escavações, barreiras para controle do fluxo em barragens, encapsulamento de solos contaminados, prevenção da liquefação de areia entre outros.

Meyersohn (2007) apresenta os testes do uso de estacas de solo-cimento como apoio da estrutura para alargamento de ponte, revelando que a alta resistência lateral em areias densas é causada principalmente por irregularidades na superfície da estaca de solo-cimento. Em construção de estruturas hidráulicas, como barragens e vertedouros, tem sido utilizado o solo-cimento que apresenta vantagens: tempo de obra mais curto, equipamentos típicos de alta taxa de produtividade, durabilidade da estrutura em climas severos e durante inundações (Bass, 2000). 
Devido ao aumento nos custos dos materiais de construção tradicionais e a pouca ou a ausência de materiais de qualidade, surge a preocupação para que se criem alternativas a serem utilizadas na construção civil. Oliveira (2004) realizou experimentos moldando-se tijolos maciços com uma mistura de solo-cimento, obtendo-se suas respectivas resistências à compressão e absorção. Alexandre et al. (2006) estudaram a adição do melhor traço para a produção de tijolos de solocimento.

Estudos realizados por Thomé et al. (2005), em fundações apoiadas em uma camada melhorada com agente cimentante, mostram que a técnica de melhorar artificialmente o solo pode ser uma alternativa de baixo custo para fundações de moderado carregamento.

\subsection{2 \\ Componentes da estabilização do solo-cimento}

Os componentes da estabilização com solo-cimente são: solo, cimento Portland, água e aditivos.

(a) Solo

O solo é o componente de maior quantidade e o mais heterogêneo na mistura solo-cimento e é natural que as características da estabilização estejam muito relacionadas com o seu comportamento e qualidade. É fundamental conhecer quais os solos mais adequados à estabilização com cimento, uma vez que podem não responder satisfatoriamente a resistência e a durabilidade, podendo exigir teores maiores de cimento e implicar em dificuldades de operações de campo. A NBR 12253/1992 enquadra as classes de solo A-1, A-2, A-3 e A-4 para dosagens de solocimento como camada de pavimento e devem conter $100 \%$ de material passante na peneira $76 \mathrm{~mm}$ e no máximo $45 \%$ de material retido na peneira $4,8 \mathrm{~mm}$.

A escolha do solo não se refere diretamente a uma característica específica desse solo, uma vez que qualquer solo endurece satisfatoriamente quando misturado com cimento e devidamente compactado (Pessoa et al., 2009). No entanto, apesar de que qualquer solo pode ser melhorado com cimento, a exceção daqueles ricos em húmus e mica, pode-se afirmar que solos arenosos de boa graduação e com plasticidade média a baixa são os mais suscetíveis a serem estabilizados com cimento, por requerem baixos teores do aditivo. Por outro lado, os solos com 
elevada plasticidade são problemáticos, já que requerem além de maiores teores de cimento, energéticos equipamentos misturadores (Ceratti, 1991).

Segundo Pereira (1970) citado por Dias (2012), a influência do solo processa-se através de várias formas: granulometria, plasticidade, composição química das partes orgânicas e mineralógicas, atividade química da superfície das partículas finas, etc.

Segundo Croft (1967) a composição mineralógica e química do solo influencia muito o sucesso do processo de estabilização com cimento. Solos cauliníticos e ilíticos são inertes e desenvolvem satisfatórias resistências com quantidades econômicas de cimento, não inibindo a hidratação e o endurecimento do cimento. Por outro lado, a presença de argilominerais montmoriloníticos retarda a hidratação do cimento, sendo mais adequada uma estabilização com cal. A afinidade da cal com a montmorilonita reduz o $\mathrm{pH}$ da fase aquosa, consequentemente, retarda o endurecimento do gel de cimento e cristalização de novos minerais.

A adequabilidade de um solo depende da presença de substâncias nocivas, tais como as orgânicas e sais. Enamorado (1990) e Marangon (1992) citam autores que concluem que o efeito prejudicial da matéria orgânica depende do seu tipo, ou seja, celulose, linhita, gelatina e compostos orgânicos com elevada massa molecular pouco afetam o solo-cimento. No entanto, açucares, glicose, ácidos húmicos e compostos orgânicos de baixa massa molecular são prejudiciais à mistura. Essa ação se manifesta no retardo do endurecimento do cimento, fato este explicado pela absorção de íons de cálcio liberado durante a hidratação do cimento.

De acordo com Pessoa et al. (2009), quando a matéria orgânica é constituída apenas de celulose, o solo poderá ser empregado com êxito na mistura solocimento. Porém, na presença de húmus, mesmo em baixas porcentagens, este reagirá com a $\mathrm{CaO}$ do cimento, o que resultará na necessidade de maiores teores de cimento para se terem resultados idênticos aos obtidos na ausência destes elementos, uma vez que o excesso de cimento terá por função neutralizar o efeito negativo do húmus.

Nas considerações de Tremblay et al. (2002), em relação aos estudos de diferentes compostos orgânicos em dois tipos de solo, pôde-se constatar que fibras celulósicas não causam algum problema no processo de cimentação; ácidos orgânicos com $\mathrm{pH}<9$ impedem o desenvolvimento dos produtos da hidratação, 
uma vez que o pH é baixo para permitir a formação de minerais secundários; e óleos e hidrocarbonetos são prejudiciais ao atraso na hidratação do cimento porque eles envolvem as partículas do cimento, porém não afetam a resistência final quando comparado ao mesmo solo sem a presença desses compostos.

A presença de sais é prejudicial às misturas de solo-cimento, segundo Enamorado (1990), os sulfatos de cálcio ou de magnésio reagem com o alumínio tricálcico do cimento hidratado provocando aumento de volume e consequente desintegração do solo-cimento. A partir da hidratação do cimento, em presença da umidade, o sulfato no meio ambiente e no próprio cimento reagem formando a etringita, que devido à quantidade de água de cristalização presente nela, resulta num aumento de volume e consequentes fissurações.

(b) Cimento Portland

O conceito de cimento Portland, de acordo com Petrucci (2005) é de ser um material pulverulento, constituído de silicatos e aluminatos de cálcio, praticamente sem cal livre, que ao serem misturados com água, hidratam-se e produzem o endurecimento da massa, podendo então oferecer elevada resistência mecânica.

A Tabela 2.1 apresenta a composição em óxidos dos cimentos nacionais. Os quatro primeiros óxidos são os principais e deles derivam os compostos fundamentais, que irão governar as propriedades do produto, e cada um deles contribui de maneira diferente nessas propriedades. Esses compostos são anidros estáveis que em presença da água transformam-se em compostos hidratados menos estáveis.

Tabela 2.1 Composição em óxidos dos cimentos nacionais (Petrucci, 2005).

\begin{tabular}{ll|lc}
\hline $\mathrm{CaO}$ & 61 a $67 \%$ & $\mathrm{MgO}$ & 0,8 a $6 \%$ \\
$\mathrm{SiO}_{2}$ & 20 a $23 \%$ & $\mathrm{SO}_{3}$ & 1 a $2,3 \%$ \\
$\mathrm{Fe}_{2} \mathrm{O}_{3}$ & $2 \mathrm{a} 3,5 \%$ & Alcalis & 0,3 a $1,5 \%$ \\
$\mathrm{Al}_{2} \mathrm{O}_{3}$ & 4,5 a $7 \%$ & & \\
\hline
\end{tabular}

Segundo a Associação Brasileira de Cimento Portland - ABCP (2014), o mercado brasileiro dispõe de 8 opções de cimento:

1. Cimento Portland Comum (CP I)

a. CP I - Cimento Portland Comum

b. CP I-S - Cimento Portland Comum com Adição 
2. Cimento Portland Composto (CP II)

a. CP II-E - Cimento Portland com Escória

b. CP II-Z - Cimento Portland com Pozolana

c. CP II-F - Cimento Portland com Fíler

3. Cimento Portland de Alto-Forno (CP III)

4. Cimento Portland Pozolânico (CP IV)

5. Cimento Portland de Alta Resistência Inicial (CP V-ARI)

6. Cimento Portland Resistente a Sulfatos (RS)

7. Cimento Portland de Baixo Calor de Hidratação (BC)

8. Cimento Portland Branco (CPB)

O Quadro 2.1 apresenta os tipos de cimento Portland e as normas brasileiras referentes a cada tipo, segundo a ABCP (2014):

Quadro 2.1 Tipo de cimento Portland, segundo ABCP (2014).

\begin{tabular}{|l|c|}
\hline \multicolumn{1}{|c|}{ Tipo } & Norma NBR \\
\hline Comum & 5732 \\
Composto & 11578 \\
Alto-forno & 5735 \\
Pozolânico & 5736 \\
Alta Resistência Inicial & 5733 \\
Resistente a Sulfatos & 5737 \\
Baixo Calor de Hidratação & 13116 \\
Branco & 12989 \\
\hline
\end{tabular}

Para esclarecer o mecanismo de hidratação do cimento, uma vez que será importante no processo de mistura do solo com o aditivo, Castro (1981) o divide em quatro etapas:

I - essa etapa inicial é bastante exotérmica (40 cal/g/h) com duração aproximada de 5 a 10 minutos e somente cerca de $1 \%$ do cimento se hidrata. Os componentes do cimento começam a reagir liberando hidróxido de cálcio que se dissolve parcialmente na fase aquosa, elevando o $\mathrm{pH}$ para 13. A solução torna-se super-saturada, precipitando $\mathrm{Ca}(\mathrm{OH})_{2}$ como cristais hexagonais mais ou menos cristalinos; 
II - na segunda etapa, a energia liberada pela reação cai para $1 \mathrm{cal} / \mathrm{g} / \mathrm{h}$, permanecendo nesse valor por cerca de $1 \mathrm{~h}$. Durante esse período, denominado de indução, as superfícies dos grãos ficam cobertos com géis neo-formados;

III - a terceira etapa é a mais importante de todo o processo. Nesta, é onde ocorre o período de pega e o calor liberado aumenta para $5 \mathrm{cal} / \mathrm{g} / \mathrm{h}$ e dura em média de $6 h$;

IV - na quarta etapa há o endurecimento, quando o calor da reação volta a ser de $1 \mathrm{cal} / \mathrm{g} / \mathrm{h}$ e sua duração varia de semanas a anos.

Ao misturar cimento com água tem-se início as etapas descritas acima e se evidencia pelo aumento brusco da viscosidade da pasta e elevação da temperatura. Com o tempo, a pasta formada cessa de ser deformada para pequenas cargas e se torna um bloco rígido. Este é o período de pega. Em seguida, a pasta continua a aumentar em coesão e resistência, denominando-se esta fase de endurecimento. A pega do cimento é importante, pois através dele se tem ideia do período disponível para as operações de trabalho em campo com o cimento (Petrucci, 2005).

Não existem restrições ao tipo de cimento a ser usado na estabilização de solos. No entanto, Jung et al. (2012) concluíram que a escolha do agente cimentante irá influenciar a resistência mecânica. Para uma mistura com areia de Osório e cimento Portland composto (CP II-E) a resistência à compressão média foi $16 \%$ superior à observada para o cimento pozolânico (CP IV). A resistência da mistura com cimento Portland de alta resistência inicial (CP V-ARI) foi 36\% superior ao do CP II-E e 58\% superior ao do CP IV.

Enamorado (1990) cita que a utilização do cimento de alta resistência inicial neutraliza o efeito da matéria orgânica presente no solo, devido a maior quantidade de íons de cálcio que liberam esses cimentos durante a hidratação.

Joel e Agbede (2011), trabalhando com um solo laterítico residual da Nigéria classificado como A-2-7 pela AASHTO e GP pela USCS, concluíram que os limites de Atterberg, LL, LP e IP, reduziram de 41,1; 24,0 e 17,1\% no solo natural para 12,$6 ; 10,1$ e $2,5 \%$, respectivamente, com adição de $60 \%$ de areia e $6 \%$ de cimento. Ainda segundo os autores, a resistência à compressão não confinada após 7 dias apresentou bem maior que o mínimo exigido e o CBR atingiu valores de $420 \%$, considerando uma mistura desse solo laterítico com $45 \%$ de areia e $6 \%$ de cimento. 
(c) Água

Para um adequado uso na mistura de solo-cimento, a água não deve conter impurezas, que venham prejudicar as reações envolvidas, tais como sais, álcalis, ácidos e matéria orgânica (Marangon, 1992).

Os mesmos cuidados com a qualidade da água para o concreto podem ser os mesmos naquela que é adicionada na mistura solo-cimento. Petrucci (2005) relaciona algumas substâncias impuras mais comuns: carbonatos e bicarbonatos alcalinos, cloretos e sulfatos de sódio, sais de cálcio e magnésio, sais de ferro, manganês, titânio, zinco e cobre. Os efeitos são adversos podendo acelerar ou retardar a pega e até afetar a resistência.

A água do mar tem sido usada e o seu emprego é recomendável quando houver no solo material orgânico prejudicial (Enamorado, 1990).

\section{(d) Aditivos}

A presença de aditivos pode melhorar o comportamento da mistura ou reduzir o teor de cimento, sendo os mais usados a cal, cloreto de cálcio e certos sais de sódio como o cloreto e o hidróxido de sódio (Cruz, 2004).

O tratamento do solo com álcalis fortes favorece as reações do quartzo com os estabilizadores alcalinos, como o cimento e a cal, podendo elevar a resistência inicial em 15 a 400\%, segundo Ferreira e Freire (2004). De acordo com os autores, os silicatos de sódio reagem com os sais solúveis de cálcio em soluções aquosas para formar silicatos de cálcio gelatinosos insolúveis; os silicatos de cálcio hidratados são agentes cimentantes e melhoram a estabilidade do solo, preenchendo seus vazios e expulsando a água do solo.

Segundo Pereira (1970) citado por Cruz (2004), o cloreto de cálcio, em quantidades de $1 \%$, acelera a pega do cimento, sendo utilizado como acelerador de resistência, essencialmente a baixas temperaturas. Esse aditivo ainda libera iões de cálcio que serão absorvidos pela matéria orgânica ou compensarão a perda desses iões que a matéria orgânica provoca no cimento. Já o cloreto de sódio reduz a retração das misturas. 


\subsection{3 \\ Mecanismos de estabilização do solo-cimento}

Belincanta et al. (2006) descrevem que no concreto a pasta de cimento envolve completamente os sólidos inertes, solidarizando-os através de ligações fortes e resistentes e nos solos, mesmo naqueles granulares, o cimento geralmente não envolve totalmente os sólidos, sendo os mesmo somente solidarizados em seus pontos de contato.

Concha (1986) descreve que em solos coesivos, o cimento a hidratar-se desenvolve fortes pontes entre partículas do solo formando uma matriz que o encaixa dentro dele. Essa matriz é muito efetiva na fixação das partículas, tal que elas não podem deslizar uma em relação às outras. Assim, o cimento não só destrói a plasticidade, como ainda prevê um incremento na resistência ao cisalhamento.

As reações químicas desenvolvidas pelo cimento, ou seja, as reações de hidratação são a origem do endurecimento da mistura solo-cimento. Dependendo o teor do agente estabilizante, a ação estabilizadora do cimento pode ocorrer segundo dois mecanismos distintos como descreve Pereira (1970) citado por Cruz (2004):

- ação aglutinante que cimenta as partículas de solo permitindo o aumento da resistência mecânica. Para essa ação, o teor de cimento é mais elevado e forma núcleos interligados distribuídos pela massa se solo (Figura 2.5a);

- ação modificadora da fração argilosa que diminui a plasticidade do solo, podendo ser ou não acompanhada do aumento de resistência mecânica, uma vez que o cimento, nestes casos, forma núcleos independentes na massa de solo (Figura 2.5b).

(a)

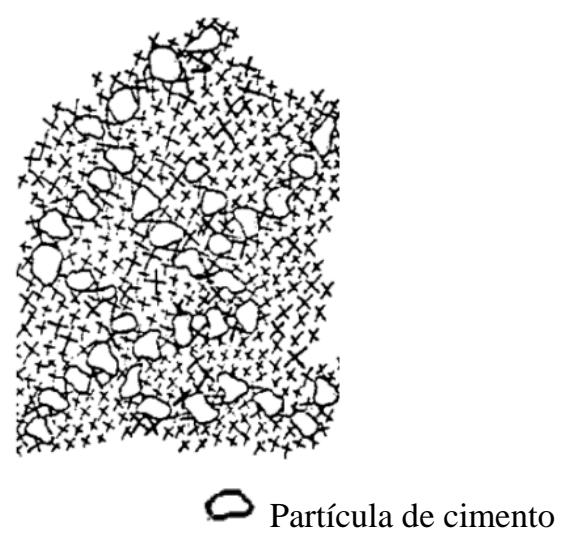

(b)

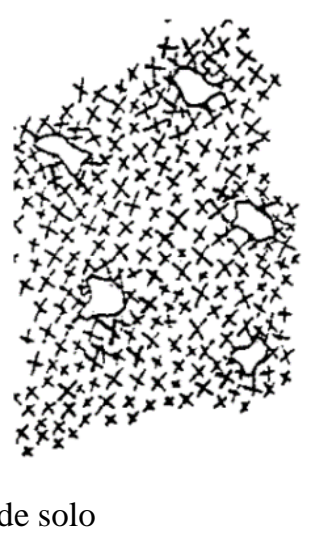

Figura 2.5 Esquema de solo com a) alto teor de cimento e b) baixo teor de cimento (Catton, 1962 apud Cruz, 2004). 
De um modo geral, algumas características de estabilização de solo com cimento encontram-se reunidas no Quadro 2.2.

Quadro 2.2Características da estabilização de solos com cimento (Pereira, 1970 apud Cruz, 2004).

\begin{tabular}{|c|c|c|c|c|c|c|c|c|c|c|c|}
\hline \multirow[b]{2}{*}{$\begin{array}{c}\text { Tipo de ação } \\
\text { do cimento }\end{array}$} & \multirow{2}{*}{$\begin{array}{c}\text { Efeito } \\
\text { principal do } \\
\text { cimento }\end{array}$} & \multirow{2}{*}{$\begin{array}{l}\text { Mecanismo } \\
\text { básico de } \\
\text { estabilização }\end{array}$} & \multirow{2}{*}{$\begin{array}{l}\text { Aplicações } \\
\text { mais } \\
\text { adequadas }\end{array}$} & \multirow{2}{*}{$\begin{array}{c}\text { Teor em } \\
\text { cimento } \\
\text { (peso) }\end{array}$} & \multirow{2}{*}{$\begin{array}{l}\text { Métodos de } \\
\text { avaliação da } \\
\text { influência do } \\
\text { cimento }\end{array}$} & \multicolumn{4}{|c|}{$\begin{array}{c}\text { Variações das propriedades do } \\
\text { solo }\end{array}$} & \multirow[b]{2}{*}{$\begin{array}{l}\text { Técnica } \\
\text { construtiva }\end{array}$} & \multirow[b]{2}{*}{ Limitações } \\
\hline & & & & & & 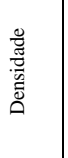 & 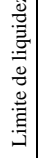 & 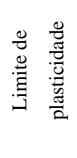 & 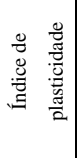 & & \\
\hline
\end{tabular}

Rodriguez (1992) descreve um modelo de estrutura, proposto por Herzog (1967), para solo-cimento denominado matriz-esqueleto: numa argila, cuja estrutura é feita de domínios de tamanhos diferentes, existem vazios interconectados numa certa extensão - esses domínios consistem em placas de argila orientada paralelamente em pacotes fechados, comportando-se como unidades estruturais em argilas. A hidratação do cimento e a ocorrência de reações secundárias formam um corpo no qual o centro endurecido de cimento é rodeado por uma zona desses domínios argilosos que se unem por cimentação “interdomínio". Externamente a esta zona formam-se canais pelos macroporos interconectados dentro da massa argilosa que podem ficar revestidos de cimento e se apresentam como ramificações relativamente fortes e reforçadas, estendendo-se do corpo à matriz inalterada (Figura 2.6).

Rodrigues (1992) ainda descreve que se o conteúdo de cimento for muito baixo, tais unidades de esqueleto se comportam como partículas bem granulares e separadas, flutuando na matriz argilosa. Aumentando-se um pouco a quantidade de cimento, as unidades do esqueleto ficam menos espaçadas, porém não interconectadas. Já com conteúdo maior, o espaço entre elas é menor e as ramificações tornam-se interligadas, aumentando a resistência e a estabilidade da matriz argilosa. Para quantidades de cimento ainda maiores não há produção de 
matriz, sugerindo a formação de um esqueleto rígido, completamente interconectada, tornando-se maior fonte de resistência do sistema.

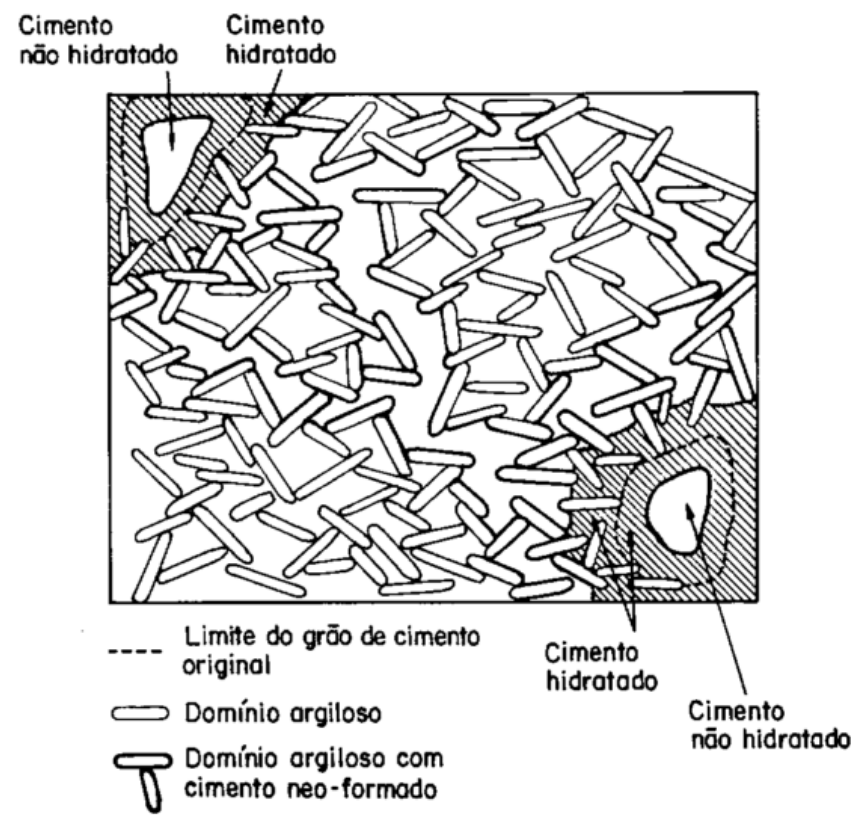

Figura 2.6 Modelo da estrutura matriz-esqueleto do solo-cimento (Herzog, 1967 apud Rodrigues, 1992).

Segundo Concha (1986) e Rodrigues (1992), nos solos granulares a ação do cimento aproxima-se do que acontece no concreto (desenvolvimento de vínculos de coesão nos pontos de contato entre os grãos), excetuando-se o fato de que aqui o cimento não preenche todos os vazios do agregado.

Chang e Woods (1992) estudaram a microestrutura de areias cimentadas e as análises indicaram que, para níveis baixos de cimentação, há uma união inicial entre as partículas do solo com o material cimentante, sendo este recobrindo parcialmente a superfície das partículas do solo. Para solos com níveis intermediários de cimentação, desenvolvem-se maiores pontos de contato entre as partículas. Quando os níveis de cimentação são altos, o agente cimentante preenche os espaços vazios entre as partículas e o efeito desse agente é mais nítido, dificultando a distinção das partículas de solo e dos produtos cimentantes.

Uma micrografia óptica de uma mistura de $8 \%$ de cimento a um solo arenoso bem graduado é apresentada na Figura 2.7a. Nela pode observar uma ponte de cimentação entre os grãos, bem como numerosos espaços intergranulares vazios. Em contraste, pode-se observar a Figura $2.7 \mathrm{~b}$ a micrografia óptica de um concreto simples, onde é visível a compacidade da microestrutura. 
Uma micrografia óptica de uma mistura de $8 \%$ de cimento em uma areia monogranular é mostrada na Figura 2.8. Pode-se observar o aumento do volume de vazios intergranulares.

(a)

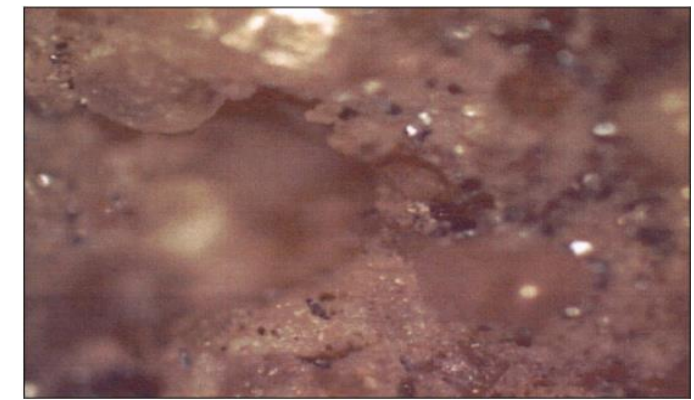

(b)

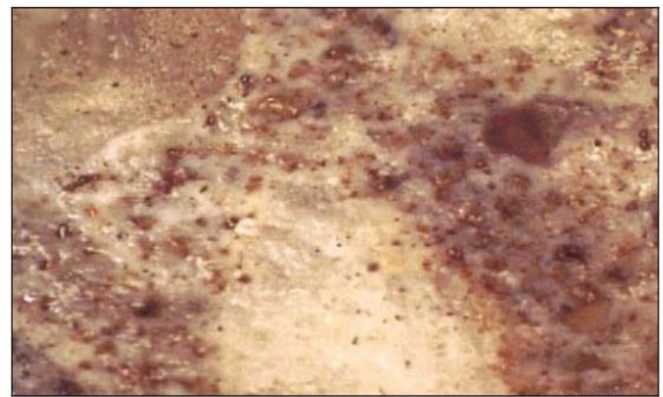

Figura 2.7 Micrografia óptica (200x) de uma mistura solo-cimento (a) e de concreto (b) (Santos, 2008).

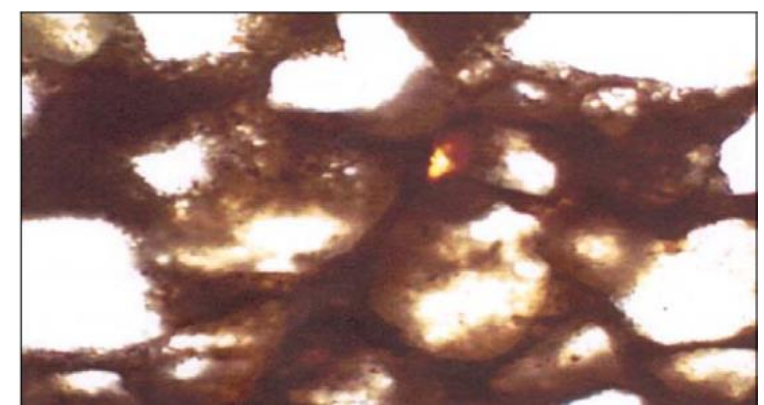

Figura 2.8 Micrografia óptica (200x) de uma mistura de areia monogranular e $8 \%$ de cimento (Santos, 2008).

Nos solos finos, as partículas coloidais de dimensões máximas iguais à menor dimensão das partículas de cimento são absorvidas pela superfície do grão de cimento, formando uma película que não permite a difusão dos íons, interferindo o desenvolvimento da hidratação do cimento e impedindo o crescimento dos cristais. Apesar da mistura desse tipo de solo em suficientes dosagens de cimento, verificase que parte do ligante não contribuirá para a consolidação da microestrutura, permanecendo por hidratar, tal como um fíler de baixa hidraulicidade, podendo inviabilizar econômica e tecnicamente a estabilização (Santos, 2008). 


\subsection{4 Fatores que influenciam a estabilização de solo com cimento Portland}

A qualidade da mistura final de solo e cimento depende de muitos fatores, pois podem influenciar diretamente na sua resistência. Segundo Marangon (1992), a bibliografia especializada tem considerado como sendo relevantes alguns fatores: granulometria do solo, grau de compactação, tipo e tempo de cura associado à temperatura, tempo entre a mistura e sua compactação, quantidade de água na hidratação do cimento e a homogeneização da mistura, quantidade de cimento (e.g. Enamorado, 1990; Cruz, 2004; Macêdo, 2004; Foppa, 2005; Portelinha, et al., 2012; Jung et al., 2012, Makusa, 2012).

\section{(a) Granulometria}

Marangon (1992) descreve que solos de granulometria mais fina, como a argila, são menos indicados para a estabilização com cimento, enquanto que solos de granulometria mais grossa são mais indicados, sendo que os bem graduados requerem um teor de cimento ainda menor, pois as numerosas áreas de contato entre as partículas produzirão uma ação cimentante mais forte. Para areias de graduação uniforme, que têm um menor número de áreas de contato entre os grãos, necessitam um maior teor de cimento (Figura 2.9).

Lasisi e Ogunjide (1984) mostraram através de estudos realizados com solos lateríticos em várias proporções de cimento, que a resistência à compressão é inversamente proporcional ao tamanho dos grãos. Esse efeito pode ser atribuído ao aumento nas forças de coesão que ligam as partículas. Os resultados apresentados indicam uma queda gradual na resistência com o aumento na relação solo/cimento; aumento na resistência com a diminuição do tamanho dos grãos e com o aumento na relação solo/cimento. Isto porque a quantidade de cimento na estabilização diminui com o aumento da relação solo/cimento (Figura 2.10). 


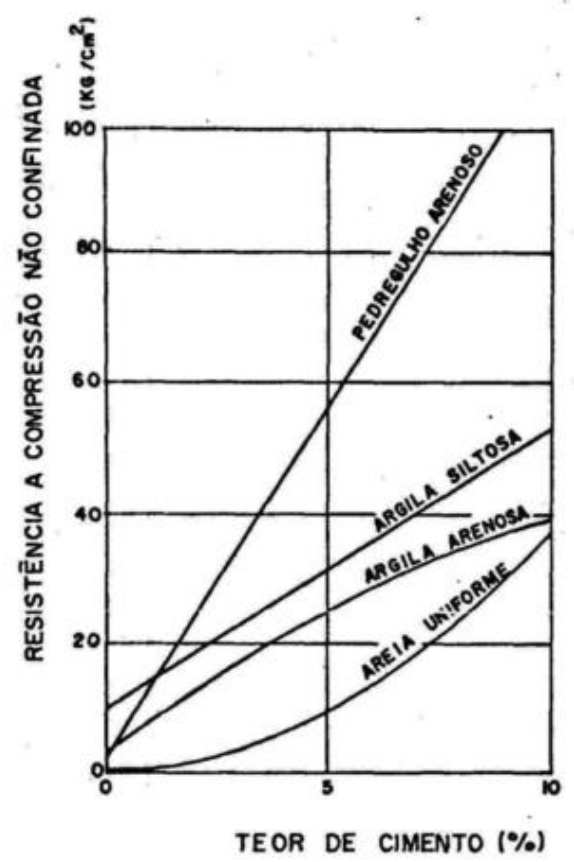

Figura 2.9 Efeito do teor de cimento na resistência para vários tipos de solo (METCALF, 1969 apud MARANGON, 1992).
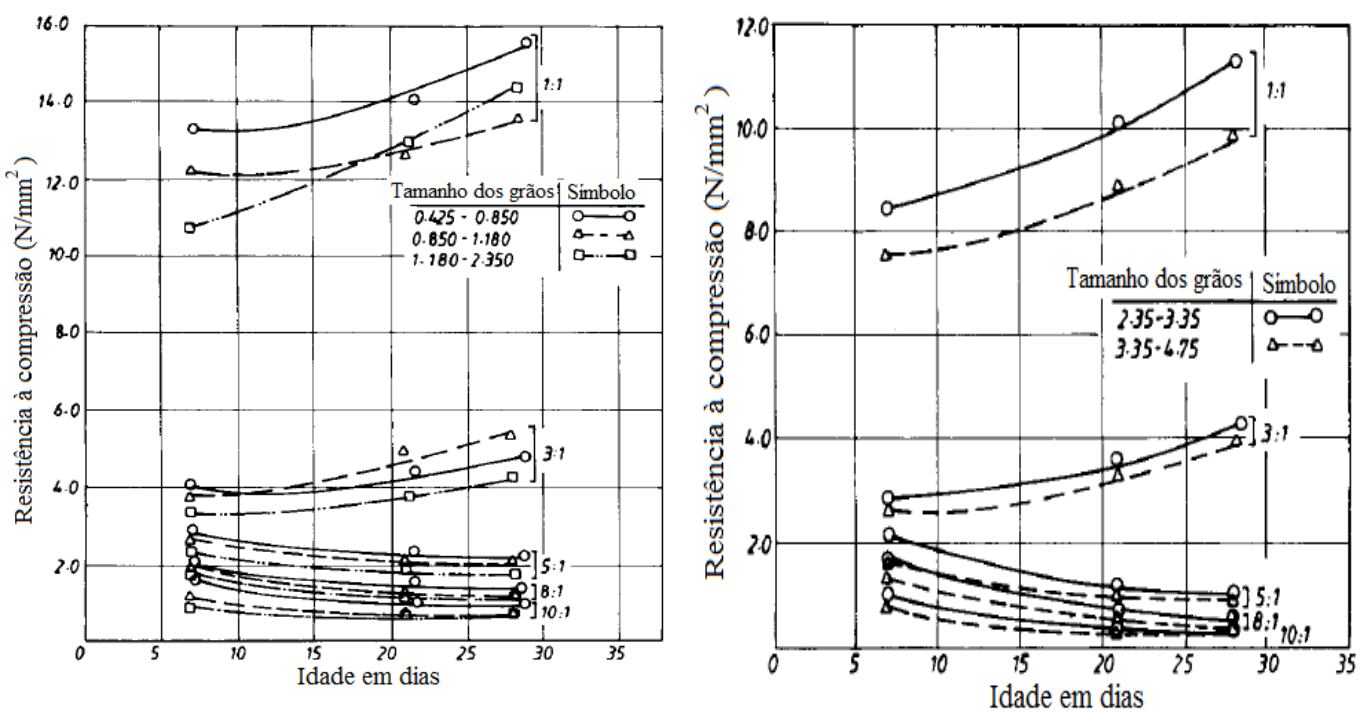

Figura 2.10 Resistência à compressão versus idade (em dias) para diferentes misturas solo/cimento (adaptada de Lasisi e Ogunjide, 1984).

(b) Teor de cimento

Como constitui um dos componentes principais na estabilização de solos, o cimento deve ser adicionado em quantidades determinadas. Já foi referido que a quantidade desse estabilizante pode variar o que leva a duas denominações: solo melhorando com cimento e solo-cimento.

A estabilização com cimento apresenta melhorias nas propriedades do solo (Makusa, 2012): 
- redução na coesão (plasticidade);

- diminuição na expansão ou compressibilidade;

- aumento na resistência

Para Sherwood (1993) citado por Cruz (2004) as retrações em solos granulares são menores do que em solos mais finos, provavelmente devido a associações deste efeito por parte do solo e por parte do cimento. De acordo com Bernucci et al. (2010) é comum a presença de fissuras e/ou trincas que formam inicialmente em bases do tipo solo-cimento, devido à retração ocasionada pela hidratação do cimento (cura), bem como pela contração consequente à perda de umidade.

Em geral, a resistência cresce com o aumento do teor de cimento, dependendo do tipo de solo empregado. Villar Filho et al. (1982) e Belincanta et al. (2006) mostram que a resistência à compressão simples de solos lateríticos aumenta com os vários teores de cimento.

A norma NBR 12253/92 fixa as condições exigíveis para a determinação da quantidade de cimento sob uma resistência mínima de 2,1 $\mathrm{MPa}$ aos sete dias de cura, seguindo os seguintes passos:

I - de acordo com a classificação granulométrica (A1, A2, A3 ou A4) são sugeridos teores em massa (\%) que variam de 5 a $10 \%$ para execução de compactação do solo-cimento;

II - determinar os parâmetros de compactação, segundo a NBR 12023, com o teor sugerido de cimento;

III - moldar corpos de prova para ensaios de compressão simples com um ou mais teores de cimento, de forma que atinja resistência mínima de 2,1 MPa. Como orientação na escolha do teor de cimento, podem ser empregadas as Figura $2.11 \mathrm{e}$ Figura 2.12, respectivamente, para solos com $100 \%$ de material passando na 4,8 $\mathrm{mm}$ e para solos com algum material retida nela;

IV - cada teor de cimento devem ser moldados três corpos de prova, nas condições da NBR 12024; 


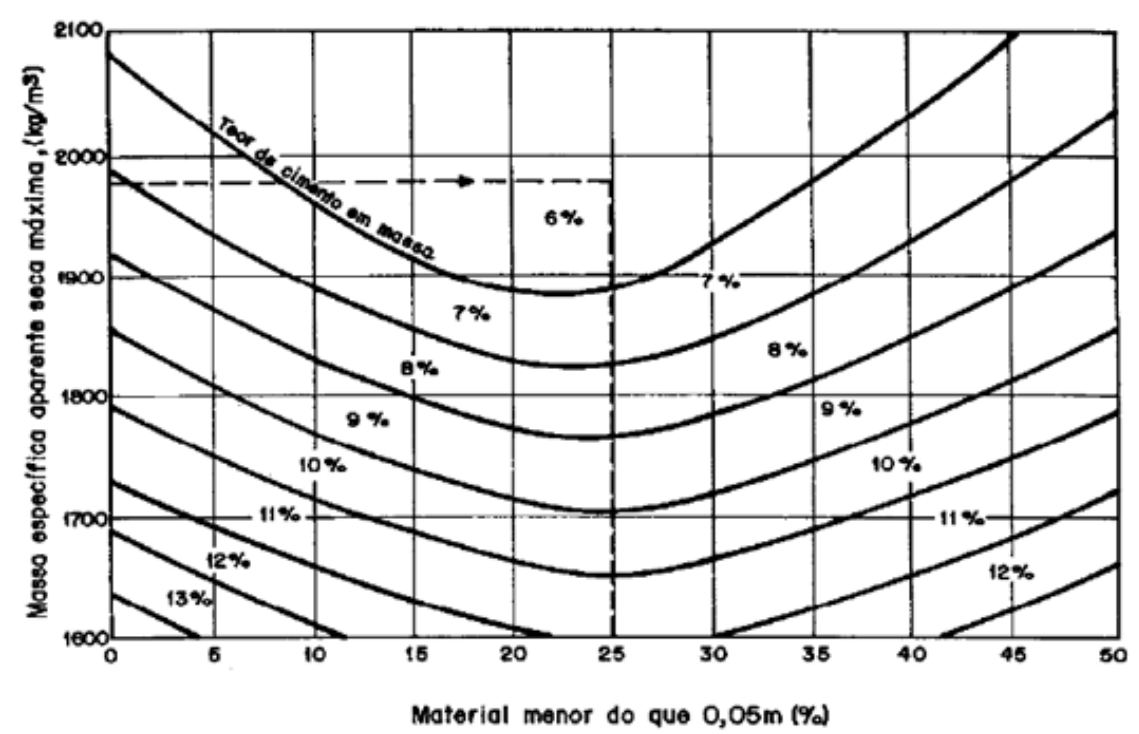

Figura 2.11 Teor de cimento em massa, para o ensaio de compressão simples, em função da porcentagem de material menor do que $0,05 \mathrm{~mm}$ e da massa específica aparente seca máxima (NBR 12253/92).

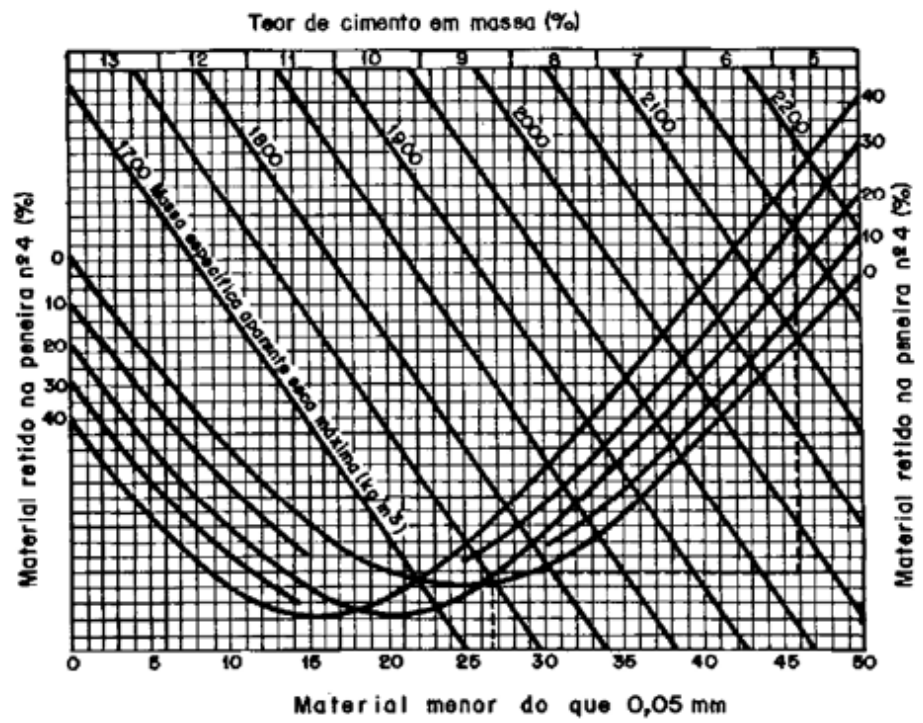

Figura 2.12 Teor de cimento em massa, para o ensaio de compressão simples, em função da porcentagem de material menor do que $0,05 \mathrm{~mm}$ e de material retido na peneira $\mathrm{n}^{\circ} 4 \mathrm{e}$ da massa específica aparente seca máxima (NBR 12253/920.

V - após cura de sete dias, os corpos de prova devem ser imersos por 4 horas em água e submetidos ao ensaio de compressão simples, conforme as condições da NBR 12025;

VI - calcular as médias aritméticas das resistências que cumprirem as tolerâncias de moldagem, contidas na NBR 12024. Devem ser excluídos da composição da média valores individuais de resistência que se afastem mais de $10 \%$ da média; 
VII - deve ser adotado como teor de cimento, o menor dos teores para o qual a resistência média à compressão for igual ou superior a 2,1 $\mathrm{MPa}$, aos sete dias de cura;

VIII - Admite-se a interpolação gráfica dos dados para a determinação do teor de cimento que corresponda ao valor mínimo da resistência à compressão média especificada, sendo proibida a extrapolação de dados.

IX - O teor mínimo de cimento recomendado pela NBR 12253 é de 5\%, podendo ser empregados teores de até $3,5 \%$, em massa, desde que satisfeita a resistência mínima, que a mistura se processe em usina e que o solo matéria-prima seja A1-a, A1-b ou A2-4.

Um outro método de dosagem é o físico-químico, originalmente proposto na Índia e em estudo na COPPE desde 1985 com argilominerais, oxi-hidróxidos de ferro e alumínio puros, bem com solos de todo o território brasileiro abrangendo diversas categorias pedológicas, amplas faixas de composição química, mineralógica, grau de intemperismo, granulometria e microagregação (Casanova, 1992).

Segundo Rodrigues (1992) o princípio da dosagem é a seguinte: a interação elétrica do cimento com as partículas argilosas contribui para as mudanças físicoquímicas complexas na mistura solo-cimento. As partículas de cimento se comportam na mistura como carregadas eletricamente e sua presença no solo aumenta a condutividade elétrica da massa solo-cimento compactada. A interação com coloides negativamente carregados juntamente com a hidratação do cimento produz mudanças físico-químicas rápidas no sistema. Consequentemente há produção de variações volumétricas substanciais quando a mistura é suspensa em água. E são essas variações volumétricas durante o processo de interação do solo com o cimento, que proporcionam a determinação do teor de cimento que produz a mistura estável. A metodologia dessa dosagem será detalhada no capítulo 3 Materiais e Métodos.

(c) Teor de umidade e compactação

Segundo Concha (1986) para qualquer tipo de solo o máximo desenvolvimento do processo cimentante obtém-se quando a mistura de solocimento-água está altamente compactada com um teor de umidade que facilite essa 
compactação e a hidratação do cimento. $\mathrm{O}$ aumento da resistência varia linearmente com o logaritmo da densidade, como apresentado na Figura 2.13.

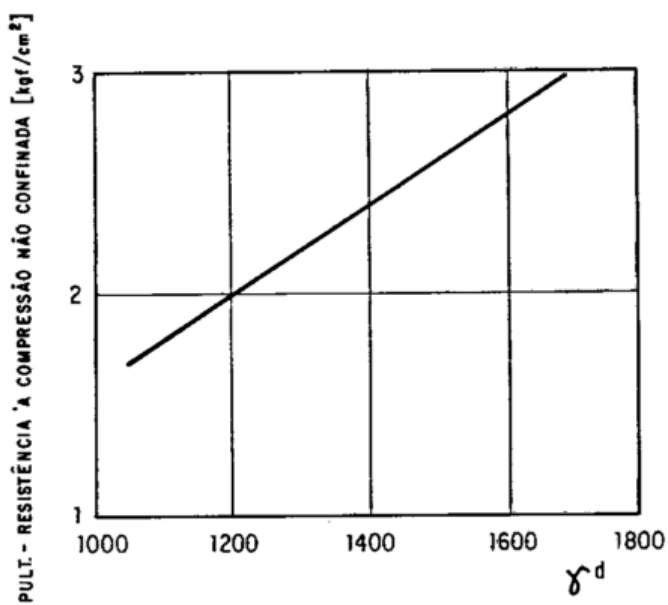

Figura 2.13 Efeito da densidade na resistência de uma argila estabilizada com $10 \%$ de cimento (Ingles e Metcalf, 1972 apud Concha, 1986).

Para Marangon (1992) é de se esperar que o máximo desenvolvimento do processo cimentante seja obtido quando em uma mistura de solo-cimento se associar uma determinada umidade capaz de levá-la a uma máxima densificação, além de hidratar todo o cimento nela contido. De fato, a quantidade de água adicionada ao solo-cimento pelo requisito da compactação geralmente ultrapassa em muito à requerida para a quase completa hidrólise do cimento, que necessita apenas de $1 / 4$ do peso do cimento. A sua presença afeta o peso específico aparente seco, o índice de vazios e o grau de saturação, além do comportamento mecânico do solo depois de compactado (Sanbonsuge, 2013).

De acordo com Pereira (1970) citado por Cruz (2004) a água nas misturas de solo-cimento permite obter a máxima densidade através da lubrificação dos grãos de solo e permite a hidratação do cimento que endurece o solo numa massa sólida. Nesse sentido, o teor em água dessa mistura deve ser compreendido entre 0,95 a 1,10 vezes o teor em água ótimo.

Hamzah (1983) citado pelo mesmo autor refere-se que o tipo de solo parece influenciar a quantidade de água da mistura: cimento misturado com areias o teor de água ideal é ligeiramente menor do que o obtido no ensaio Proctor; para solos argilosos a quantidade de água deve situar-se 1 ou $2 \%$ acima da ótima. Isto porque estes solos são constituídos por partículas de grande superfície específica e 
absorvem parte da água adicionada e aquela que ficaria disponível seria insuficiente para a hidratação do cimento.

Para essa hidratação é necessário que exista água livre no solo disponível para a reação, uma vez que deficientes teores de umidade não permitem a completa hidratação do ligante, por outro lado, um aumento destes pode arrastar as partículas de cimento e originar dosagens deficitárias em alguns pontos (Santos, 2008).

É sabido que o processo de hidratação ocorre imediatamente após o cimento entrar em contato com a água e, para uma estabilização de solo-cimento, é importante compactar a mistura o mais rápido possível, dado que qualquer atraso nessa compactação pode resultar no endurecimento da massa de solo estabilizado e, por conseguinte, um maior esforço adicional de compactação seja necessário para fazer o mesmo efeito (Makusa, 2012).

A eficiência na homogeneização e compactação é fundamental para a garantia da qualidade final da estabilização. No entanto, ao prolongar o tempo dessa homogeneização formam-se livremente ligações, ou seja, formam-se as primeiras redes cristalinas por cimentação que serão destruídas e em parte não mais reconstruídas com a posterior compactação o que faz reduzir a resistência. Em misturas de solo-cimento, a fração argilosa tende a flocular, o que provoca diminuição da densidade da mistura e consequente queda de resistência, como observado na Figura 2.14.

Esse prolongamento implica reduções na resistência, ao fim de duas horas, na ordem de 20 a 40\%. No entanto, essas perdas podem ser inferiores (até 50\%) se for feito um remeximento antes da compactação. Considera-se aceitável um tempo de duas horas, para temperaturas em torno de $25^{\circ} \mathrm{C}$, entre o início da preparação da mistura e a sua compactação, sendo aconselhado remeximentos intermitentes (Cristelo, 2001). 


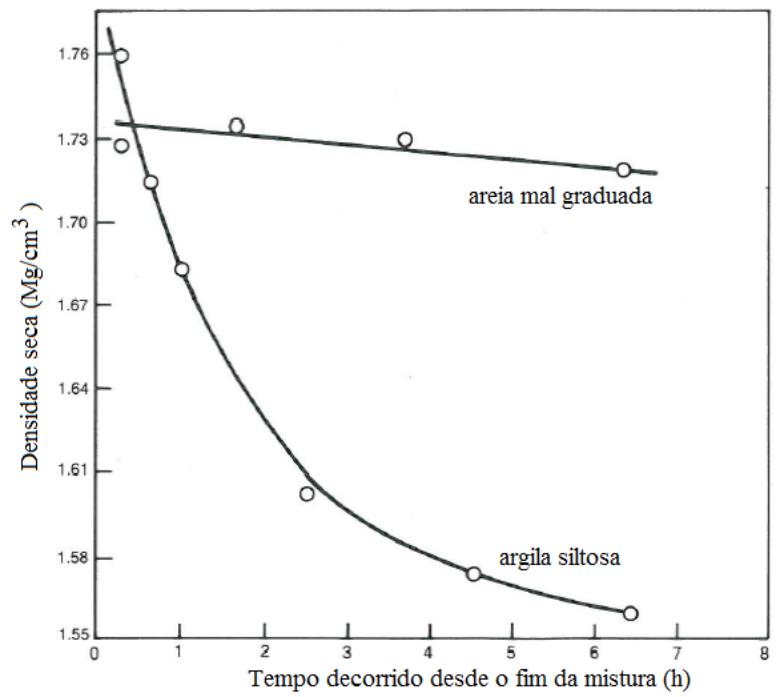

Figura 2.14 Densidade seca versus tempo decorrido desde o fim da mistura de dois materiais estabilizado com 10\% de cimento (adaptado de Sherwood, 1993 apud Makusa, 2012).

(d) Tempo e temperatura de cura

Segundo Marangon (1992), a cura é o cuidado fundamental para se garantir a qualidade prevista na dosagem e consiste na proteção do material até que ele alcance suas características. É de conhecimento que a resistência aumenta gradualmente com esse período de cura como pode ser constatado na literatura.

A Figura 2.15 apresenta o ganho de resistência com o período de cura para quatro tipos de solo.

Cruz e Jalali (2010) constataram que o aumento na resistência ocorre nos 28 dias de cura, sendo os acréscimos pouco significativos após esta idade. Foi observado também que as resistências aos 7 dias são $50 \%$ superiores dos valores atingidos aos 56 dias. Tanto Souza, Carvalho e Barroso (1998) quanto Belincanta et al. (2006) estudaram os ganhos de resistência com o tempo de cura de solos lateríticos com vários teores de cimento. Segundo os últimos autores, o crescimento dessa resistência tem sido em média $23 \%$ para os três solos analisados num período de cura de 28 a 112 dias. 


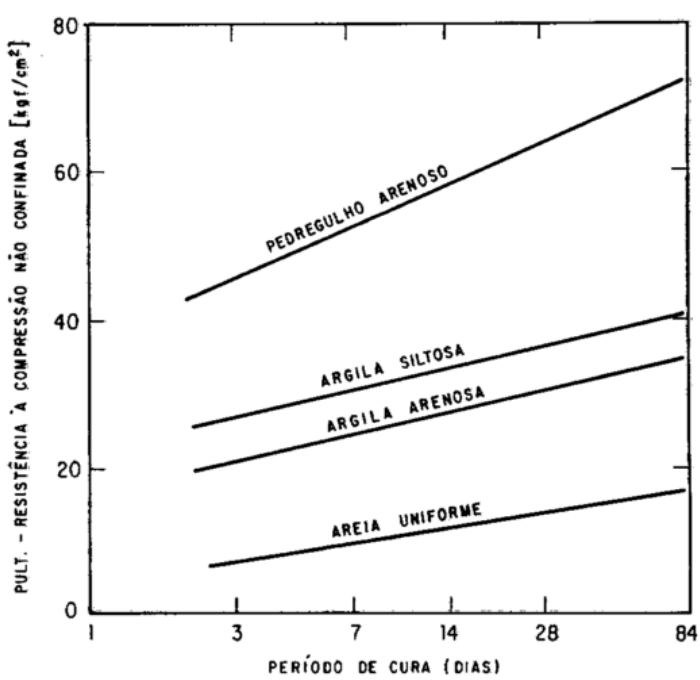

Figura 2.15 Efeito do tempo de cura para os solos estabilizados com 5\% de cimento (METCALF, 1969 apud MARANGON, 1992).

Em relação ao efeito da temperatura de cura, Ingles e Metcalf (1973) citados por Marangon (1992) concluem que em temperaturas mais elevadas são obtidos maiores ganhos de resistência, e chamam atenção para o fato de uma condição de ressecamento excessivo pode provocar fissuramento no material.

\section{4}

\section{Escória de cobre}

\subsection{1}

Breve histórico e produção mundial de cobre

Segundo historiadores, a primeira idade do cobre teve seu maior desenvolvimento no Egito, na península do Sinai, por volta de 3.800 A.C. e, inclusive, a descoberta de cadinhos nas minas dessa península indicou que a extração do metal incluía certa refinação. O emprego do cobre se espalhou por regiões onde os romanos percorriam, civilizações esta que se atribui uma era de uso mais intenso do metal. A maior parte do cobre romano veio da Ilha de Chipre (Cyprium) que deu origem à palavra Cuprum e à sigla $\mathrm{Cu}$ como símbolo químico do metal cobre. Sua utilização alcançou real dimensão de metal imprescindível em 1831 quando se descobriu o gerador elétrico e desde então a demanda pelo cobre cresceu de forma notável (Procobre, 2014).

Com o desenvolvimento das atividades humanas foram descobertos novos e importantes usos para o cobre e o avanço na metalurgia permitiu a produção de 
novas ligas de cobre ampliando o seu campo de aplicações (Procobre, 2014). Os principais países produtores de cobre são Estados Unidos, ex-União Soviética, Zâmbia, Chile, Canadá, Zaire, Peru, África do Sul, Austrália, Japão, Filipinas, China, Iugoslávia, Finlândia e Espanha (Procobre, 2014).

De acordo com o Sumário Mineral - ano 2015 do Departamento Nacional de Produção Mineral (DNPM), a produção mundial de concentrado de cobre, em metal contido, alcançou no ano de 2014 uma quantidade de 18,71 milhões de toneladas (2,5\% a mais em relação a 2013). Quanto ao metal, em 2014, a produção mundial de cobre refinado (primário e secundário) atingiu 22,48 milhões de toneladas (6,8\% a mais em relação a 2013). Os países China (32,5\%), Chile (13\%), Japão $(6,8 \%)$ e os Estados Unidos (5\%) foram os principais produtores de cobre (DNPM, 2015).

No Brasil, o concentrado de cobre provinha exclusivamente da mina Caraíba, localizada no município de Jaguarari, Estado da Bahia, pertencente à Mineradora Caraíba S/A, uma vez que no ano de 1998 ocorreu o fechamento da Mina Camaquã, no estado do Rio Grande do Sul, a mais antiga mina de cobre do país. Por conta da exausta exploração há um declínio na produção da mina Caraíba, sendo compensada, a partir de 2004, com a produção e comercialização do concentrado de cobre da mina Sossego, pertencente à Companhia Vale do Rio Doce, localizada no município de Canaã dos Carajás, no Estado do Pará. Com isso, a mineração brasileira mais que triplicou a sua produção de cobre passando de um patamar de 30 mil toneladas anuais (1998 - 2003) para mais de 100 mil toneladas em 2004, vindo a atingir 216 mil toneladas em 2008. Além da mina Sossego, acrescenta-se também a operação comercial em 2007 da mina de ouro e cobre da Chapada, município de Alto Horizonte, Estado de Goiás, pertencente à Mineradora Maracá S/A (MME, 2009).

Segundo o Sumário Mineral - ano 2015, a produção brasileira de concentrado de cobre em metal contido, alcançou em 2014 um total de 301.197 toneladas (11,2\% a mais em relação a 2013) distribuídas nos Estados do Pará (69,3\%), Goiás (22,2\%) e Bahia (8,5\%). A produção nacional de cobre refinado (primária mais secundária), sob a forma de catodo, atingiu em 2014 um total de 236.685 toneladas, significando um decréscimo de 9,6\% frente ao ano anterior. A produção brasileira de semimanufaturados (laminados e extrudados/trefilados) atingiu em 2014 uma quantidade de 130 mil toneladas em produtos de cobre (DNPM, 2015). 
A Tabela 2.2 apresenta a reserva e a produção mundial de cobre para alguns países, inclusive o Brasil.

Diante desses dados, infere-se que a atividade de produção do cobre gera volumes significativos de escória durante o processo de transformação das matérias-primas em produtos acabados. Em nível mundial, 13 milhões de toneladas de escória de cobre são geradas, sendo no Brasil a média de 230 mil toneladas anuais (Moura, 2000).

Tabela 2.2 Reserva e produção mundial de cobre (DNPM, 2015).

\begin{tabular}{l|c|c|c|c}
\hline \multicolumn{1}{c|}{ Discriminação } & Reservas $^{(1)}\left(10^{3} \mathrm{t}\right)$ & \multicolumn{3}{|c}{ Produção $^{(2)}\left(10^{3} \mathrm{t}\right)$} \\
\hline Brasil & 2014 & $2013^{(\mathrm{r})}$ & $2014^{(\mathrm{p})}$ & $\%$ \\
\hline Chile & $\mathbf{1 0 . 8 4 4}$ & $\mathbf{2 7 0 , 9}$ & $\mathbf{3 0 1 , 2}$ & $\mathbf{1 , 6}$ \\
\hline Peru & 209.000 & $5.780,0$ & $5.800,0$ & 31,0 \\
\hline Estados Unidos & 68.000 & $1.380,0$ & $1.400,0$ & 7,5 \\
\hline China & 35.000 & $1.250,0$ & $1.370,0$ & 7,3 \\
\hline Austrália & 30.000 & $1.600,0$ & $1.620,0$ & 8,7 \\
\hline Outros Países & 93.000 & 990,0 & $1.000,0$ & 5,3 \\
\hline Total & 257.156 & $6,994,1$ & $7.222,8$ & 38,6 \\
\hline
\end{tabular}

Fonte: DNPM; ICSG; USGS; Vale; Salobo Metais S/A; Mineração Caraíba; Mineração Maracá; Votorantim Metais Níquel; Caraíba Metais e Sindicel-ABC. Dados em metal contido. (1) Brasil: reserva lavrável (DNPM). Para outros países: reserva econômica (USGS), (2) concentrado; (r) revisado; (p) preliminar.

De acordo com Gorai et al. (2003) estima-se, para cada tonelada de cobre produzida, cerca de 2,2 toneladas de escória geradas e, por ano, aproximadamente 24,6 milhões de toneladas de escória são geradas mundialmente. A Tabela 2.3 apresenta as quantidades das principais regiões produtoras de escória no mundo.

Tabela 2.3 Geração da escória de cobre em várias regiões do mundo (Gorai et al., 2003).

\begin{tabular}{l|c}
\hline \multicolumn{1}{c|}{ Região } & Geração de escória de cobre/ milhões de toneladas anuais \\
\hline Ásia & 7.26 \\
\hline América do Norte & 5.90 \\
\hline Europa & 5.56 \\
\hline América do Sul & 4.18 \\
\hline África & 1.23 \\
\hline Oceania & 0.45 \\
\hline
\end{tabular}




\subsection{2 \\ Caracterização geral da escória de cobre}

No minério os óxidos e sulfatos combinam covalentemente para formar as fases $\mathrm{Cu}-\mathrm{Fe}-\mathrm{O}-\mathrm{S}$ na ausência da sílica. Durante a fusão, quando a sílica é adicionada, combina com os óxidos para formar silicatos que se agrupam para formar a escória. Certa quantidade de alumina e cal é adicionada para estabilizar a estrutura da escória (Gorai et al. 2003).

A escória fundida quando descarregada do forno está a uma temperatura variando de 1000 a $1300{ }^{\circ} \mathrm{C}$, sendo então resfriada lentamente ao ar formando um produto denso, duro e cristalino (Figura 2.16a) ou resfriada bruscamente em contato com água formando um produto granular amorfo (Figura 2.16b) (Gorai et al., 2003).

(a)

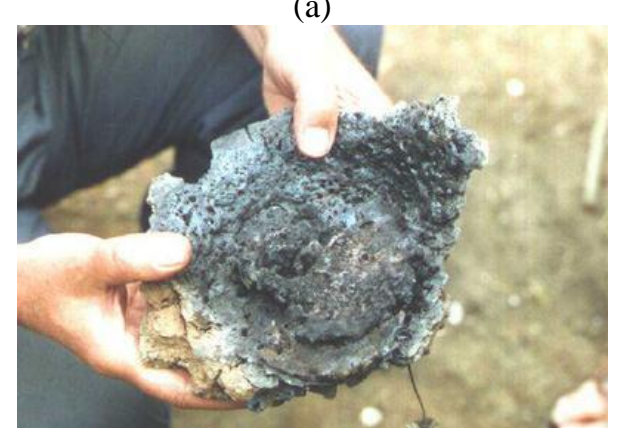

(b)

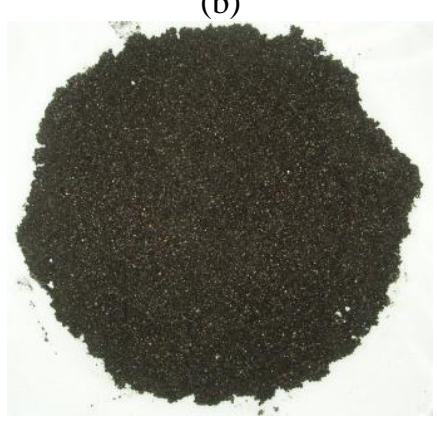

Figura 2.16 Escória de cobre: a) resfriada ao ar (Resende, 2009) e b) granulada.

Normalmente a escória de cobre encontrada é um silicato de ferro vítreo impuro com pequenas proporções de cobre e sulfetos de cobre e apresenta uma composição química variada (Gorai et al., 2003).

(a) Caracterização química

O conhecimento da composição química da escória é de fundamental importância para um melhor conhecimento das reações que ocorrerão consoantes a sua utilização (Moura, 2000). Segundo Shi et al. (2008) a composição química da escória varia de acordo com a origem do minério, processo metalúrgico empregado e o tipo de forno, apesar de atualmente, conforme cita Resende (2009), com a tecnologia dos modernos altos-fornos, produz variabilidades muito pequenas nas composições para minérios de mesma origem. De acordo com Gorai et al. (2003) a 
composição típica da escória de cobre é a seguinte: Fe: 30-40\%, $\mathrm{SiO}_{2}: 35-40 \%$, $\mathrm{Al}_{2} \mathrm{O}_{3}: \leq 10 \%, \mathrm{CaO}: \leq 10 \%, \mathrm{Cu}: 0.5-2.1 \%$.

A Tabela 2.4 apresenta a composição química de algumas escórias de cobre. Como observado, a escória contém em sua composição porcentagens maiores que óxidos de silício, ferro, alumínio, cálcio e magnésio. Como os metais são mais estáveis nas formas de óxidos e silicatos, a construção com materiais produzidos a partir de escória de cobre tem menor possibilidade de corrosão (Gorai et al., 2003).

Tabela 2.4 Composição química de algumas escórias de cobre (SHI et al., 2008).

\begin{tabular}{c|c|c|c|c|c|c|l}
\hline $\mathrm{Fe}_{2} \mathrm{O}_{3}$ & $\mathrm{SiO}_{2}$ & $\mathrm{CaO}$ & $\mathrm{MgO}$ & $\mathrm{Al}_{2} \mathrm{O}_{3}$ & $\mathrm{SO}_{3}$ & $\mathrm{CuO}$ & Referência \\
\hline 44.78 & 40.97 & 5.24 & 1.16 & 3.78 & 1.06 & - & Iran \\
\hline 44.8 & 24.7 & 10.9 & 1.7 & 15.6 & 0.28 & 2.1 & USA \\
\hline 49.5 & 34.51 & 2.2 & 1.48 & 6.55 & 1.2 & 0.43 & Canadá \\
\hline 45.3 & 36.0 & 9.3 & 3.24 & 3.45 & 0.49 & 0.33 & Austrália \\
\hline 62.0 & 26.0 & 2.5 & 3.7 & - & - & 1.4 & Brasil \\
\hline 52.0 & 35.5 & 2.11 & 1.06 & 5.9 & 0.14 & 0.88 & Japão \\
\hline 60.0 & 30.07 & 0.6 & 0.75 & 3.97 & 0.32 & 0.79 & Espanha \\
\hline 53.72 & 34.3 & 7.91 & 0.94 & 3.83 & 3.02 & - & Taiwan \\
\hline 36.0 & 31.0 & 4.0 & - & 6.0 & - & $0.33-0.8$ & Malásia \\
\hline 41.53 & 37.13 & - & - & - & 0.11 & 0.79 & Chile \\
\hline 39.65 & 31.94 & 3.95 & 2.82 & 2.4 & - & 1.01 & Turquia \\
\hline
\end{tabular}

A partir da composição química e de normas específicas, Moura (2000) determinou a atividade pozolânica da escória de cobre da Caraíbas Metais. O total dos óxidos $\left(\mathrm{SiO}_{2}, \mathrm{Al}_{2} \mathrm{O}_{3}, \mathrm{Fe}_{2} \mathrm{O}_{3}\right)$ obtido do ensaio foi $84.3 \%$, sendo no mínimo de $70 \%$ para ser considerado material pozolânico. Portanto, essa escória atende às especificações de uma pozolana classe E, de acordo com a NBR 12653/19924.

\section{(b) Caracterização física}

Algumas das propriedades físicas e mecânicas são apresentadas por vários autores (Geiseler, 1996; Moura, 2000; Gorai et al., 2003; Zain et al., 2004; Al-Jabri et al., 2006; Shi et al., 2008; Prasad e Ramana, 2016).

Gorai et al. (2003) descrevem que as escórias de cobre resfriadas ao ar têm uma cor escura e aparência vítrea; densidade varia com o conteúdo de ferro entre

\footnotetext{
${ }^{4}$ ASSOCIAÇÃO BRASILEIRA DE NORMAS TÉCNIAS (ABNT). NBR 12653 - Materiais pozolânicos: especificações. Rio de Janeiro, 1992.
} 
2,8 a 3,8; pode apresentar uma massa específica maior que o agregado convencional; baixa capacidade de absorção, cerca de $0,13 \%$. Por outro lado, a escória granulada é mais porosa, com menor densidade, maior capacidade de absorção, tem uma forma regular, partículas angulares e com dimensões variando de 4,75 mm (\#3/4) e 0,075 mm (\#200).

A Figura 2.17 mostra um grão da escória de cobre que, segundo Zain et al. (2004), fisicamente é angular, escura, vítrea, brilhante e com bordas afiadas.

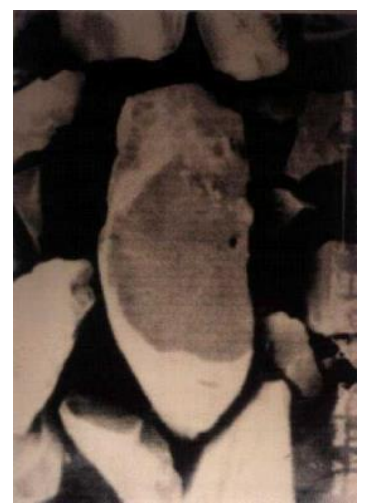

Figura 2.17 Grão da escória de cobre (ampliação 50x) (ZAIN et al., 2004).

Os resultados da caracterização física da escória de cobre apresentadas por Moura (2000) revelam uma dimensão máxima de 4,8 mm, módulo de finura 3,4, material pulverulento 0,51 , massa unitária de $2,25 \mathrm{~g} / \mathrm{cm}^{3}$ e massa específica de $3,870 \mathrm{~g} / \mathrm{cm}^{3}$. A distribuição granulométrica dessa escória é apresentada na Tabela 2.5.

Tabela 2.5 Composição granulométrica da escória de cobre da Caraíbas Metais, segundo Moura (2000).

\begin{tabular}{c|c}
\hline Peneira $(\mathrm{mm})$ & \% retida acumulada \\
\hline 9,5 & - \\
\hline 6,3 & 1 \\
\hline 4,8 & 3 \\
\hline 2,4 & 18 \\
\hline 1,2 & 51 \\
\hline 0,6 & 84 \\
\hline 0,3 & 92 \\
\hline 0,15 & 96 \\
\hline$<0,15$ & 100 \\
\hline
\end{tabular}

A escória de cobre apresenta favoráveis propriedades mecânicas para ser utilizadas como agregados, incluindo excelente característica de resistência e estabilidade, com elevado ângulo de atrito devido a sua forma angular, conforme 
observado na Figura 2.15. Gorai et al., (2003) descrevem que a escória tende a ser vítrea ou "vidradas", o que afeta negativamente as suas propriedades de atrito (resistência à derrapagem), um problema potencial se utilizadas em superfícies de pavimentos.

(c) Caracterização mineralógica

Observações microscópicas indicam que a maioria das escórias de cobre é predominantemente cristalina, apresentando uma grande incidência de picos, com a presença de cristais de faialita $\left(\mathrm{Fe}_{2} \mathrm{SiO}_{4}\right)$, faialita magnesiana $\left((\mathrm{FeMg})_{2} \mathrm{SiO}_{4}\right)$, ambos do grupo das olivinas, e magnetita $\left(\mathrm{Fe}_{3} \mathrm{O}_{4}\right)$ como mostrado pelo difratograma de raios X (Figura 2.18) citado por Moura (2000). Esse difratograma apresenta uma conformação típica com outros referenciados pelos autores Gorai et al., (2003), Resende (2009) e Murari et al. (2015), indicando uma semelhança da constituição mineralógica das escórias de cobre.

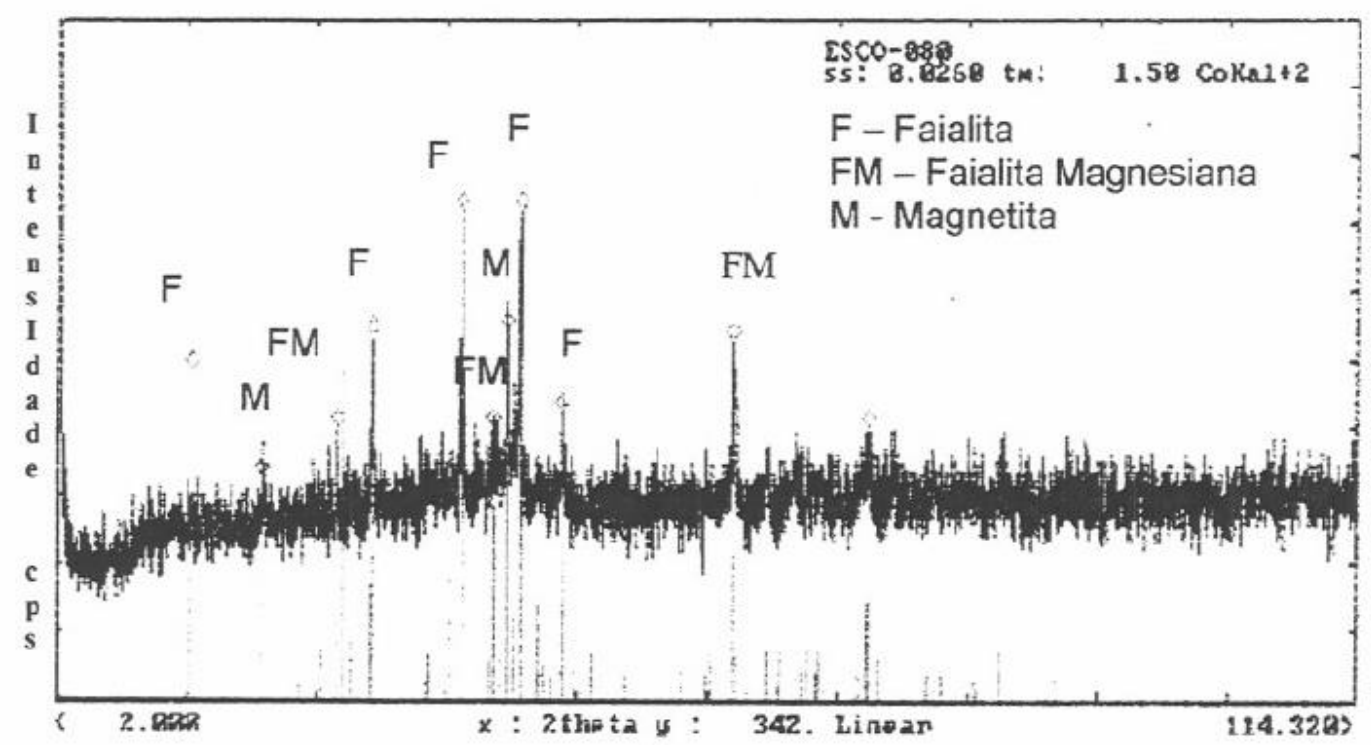

Figura 2.18 Difratograma da escória de cobre (Moura, 2000).

\subsection{3}

\section{Aplicações da escória de cobre}

Várias são as aplicações da escória de cobre destacadas por Moura (2000), Gorai et al. (2003), Al-Jabri et al. (2006), Resende (2009), Al-Jabri et al., (2011) Murari et al., (2015) Prasad e Ramana (2016). Dentre as possíveis aplicações citase: ferramenta de corte, produtos cerâmicos, vidro, abrasivos, camadas de 
pavimento, substituição parcial do cimento, agregado em mistura de cimento e outras aplicações.

\section{- Ferramentas de corte, produtos cerâmicos e vidros}

Gorai et al., (2003) cita as investigações realizadas por Szyrle et al. (1988) com o uso da escória de cobre em substituição ao convencional fíler de lithophone em ferramentas de corte. Um fíler de escória de cobre (partículas menores que 150 $\mu \mathrm{m})$ foi adicionado a uma mistura de pó abrasivo, pó de resina novolak, resina líquida fenol formaldeído e um pigmento vermelho de ferro e, então, compactada e endurecida por 16 horas numa temperatura inferior a $180{ }^{\circ} \mathrm{C}$. O disco resultante foi usado para o corte de haste de aço de $60 \mathrm{~mm}$ de diâmetro a uma rotação de 3.800 rpm. A propriedade de corte do disco composta de escória foi superior ao disco convencional de fíler de lithophone.

Nos estudos de Marghussian e Maghsoodipoor (1998) com ladrilhos nãovidrados contendo escória de cobre iraniana, a mistura de $40 \%$ de escória, em peso, argila e areia, queimada a $1025^{\circ} \mathrm{C}$ por 1 hora apresentou o melhor resultado revelando uma resistência à flexão de $57 \mathrm{MPa}$, absorção de $2 \%$ de água, dureza e boa resistência a ácidos.

Dongping et al. (1997), citado por Gorai et al., (2003), estudaram a adição de escória na fabricação de vidro colorido. Os autores realizaram uma mistura de 1243\% de escória, 35-52\% de sílica 5-18\% de cal e 15-25\% de sódio fundindo a 1300 ${ }^{\circ} \mathrm{C}$ para obter um vidro colorido. A cor do vidro muda sequencialmente desde o verde, amarelo esverdeado, marrom esverdeado até preto esverdeado com o aumento do óxido de ferro $\left(\mathrm{Fe}_{2} \mathrm{O}_{3}\right)$ na composição do vidro.

\section{- Abrasivos}

Investigações sobre a escória de cobre granulada mostrou melhoras nas propriedades mecânicas, podendo ser aplicadas em ferramentas abrasivas para a usinagem em metais não-ferrosos, madeiras e plásticos (Gorai et al., 2003). Resende (2009) descreve que a escória de cobre é muito adequada à decapagem de superfícies metálicas devido ao seu baixo custo, dureza e granulometria, sendo essas características comparáveis às dos materiais abrasivos tradicionais. Quando a escória de cobre é utilizada com a finalidade abrasiva denomina-se granalha de cobre e após o seu uso, já não apresenta a mesma granulometria nem a mesma 
constituição química. Essa alteração decorre de sucessivos impactos das partículas sobre a superfície que carreia o material incrustado nela.

Estaleiros, refinarias, indústria automobilística usam o jateamento a seco, e, como abrasivo, a escória de cobre para remoção de ferrugem, revestimento antigos e outras impurezas, uma vez que essa escória apresenta propriedades de dureza, alta densidade e baixo conteúdo de sílica livre, proporcionando um excelente acabamento na superfície (Kambham et al. 2007).

Segundo Resende (2009), apesar de Portugal não ter produção de escória de cobre, existem depósitos desse material após a sua utilização como abrasivo no tratamento de revestimentos metálicos. A granalha utilizada por esse autor provém dos Estaleiros Navais de Viana do Castelo que consomem cerca de 4.700 toneladas do abrasivo e desde 2004 que a granalha de cobre usada por esses estaleiros é crivada, transportadas para cimenteiras e reutilizada como matéria-prima no cimento. Os grãos dessa granalha são menores sofrendo reduções de 2,5 mm para $1 \mathrm{~mm}$ e quimicamente está incorporado uma quantidade significativa de partículas muito finas de óxido de ferro e partículas de tinta. Porém, o autor procedeu a lavagem da granalha batida para eliminar, dentro do possível, a sujeira incorporada após o processo de decapagem, ou seja, as partículas de óxido de ferro, resíduo de tinta, entre outros.

\section{- Camadas do pavimento}

Al-Sayed e Madany (1992) demostraram que a escória de cobre pós-jateada pode ser utilizada como agregado fino em concreto asfalto. Nos estudos os autores concluíram que a estabilidade das misturas foram acima de $8 \mathrm{KN}$ e o teor ótimo de asfalto diminuiu com o aumento da relação escória/areia e variou, em peso, de 4,4\% a $5,7 \%$.

Nos trabalhos de Moura (2000) foi detectado, através do ensaio de compactação, que a escória de cobre bruta não apresentava adesão e que a água exsudava facilmente. No entanto, em misturas contento $65 \%$ de escória e $35 \%$ de solo areno-argiloso, a mistura apresentava um excelente material para base de pavimento, com um ISC 74\% superior ao estabelecido pela norma DNER - ME 
50/19795 , a qual admite um suporte mínimo de 40\%. Para uma mistura de brita, escória de cobre e solo areno-argiloso, o ISC foi de $77 \%$.

Para a utilização da escória de cobre como agregado miúdo em asfalto prémisturado a frio, Moura (2000) descreve que a escória apresentava segregação, devido a sua elevada massa específica e para minimizar esse efeito foram elaboradas misturas com escória de ferro-cromo como agregado graúdo e emulsão de ruptura lenta (RL-1C) e ruptura média (RM-1C). Os melhores resultados foram apresentados com a mistura de ruptura lenta, não havendo segregação em ambas as misturas.

Moura (2000) ainda verificou a utilização da escória de cobre em mistura com emulsão em diversas proporções. Apesar de apresentar uma ótima adesividade, não foi possível realizar ensaios Marshall (DNER - ME 107/1979) ${ }^{6}$ nas misturas, uma vez que os corpos-de-prova desagregaram a $60^{\circ} \mathrm{C}$.

Como camada drenante em pavimentos, Moura (2000) cita que a escória acusou um coeficiente de permeabilidade médio de $0,038 \mathrm{~cm} / \mathrm{s}$ e associado à sua massa específica, aponta um bom desempenho como colchão drenante e camada estabilizadora em pavimentos de paralelepípedo.

Rapouseiras et.al (2016) em estudos com misturas de agregado, asfalto recuperado e escória de cobre, concluíram entre outras que a adição de $35 \%$ de escória e $20 \%$ de asfalto melhora o desempenho da mistura; adição de $35 \%$ de escória gera efeitos favoráveis sobre a fluência da mistura; acréscimo acima de $25 \%$ de escória reduz a estabilidade Marshall, no entanto a resistência à tração aumenta em média 8\%; para adições superiores a 25\% de escória, o quociente Marshall é reduzido a valores muito próximos aos gerados pelas misturas tradicionais.

\section{- Concreto}

Moura et al. (2009) apresentaram um estudo sobre a utilização de escória de cobre como agregado miúdo para concreto. Na avaliação do comportamento mecânico foram produzidas misturas de referência (sem escória) e com escória

\footnotetext{
${ }^{5}$ DEPARTAMENTO NACIONAL DE ESTRADAS DE RODAGEM. DNER-ME 50: determinação do índice de suporte Califórnia. Rio de Janeiro , 1979. ${ }^{6}$ DEPARTAMENTO NACIONAL DE ESTRADAS DE RODAGENS. DNER-ME 107: ensaio marshall. Rio de Janeiro, 1979.
} 
numa proporção de 30, 40 e 50\% em substituição (em volume) à areia natural. Segundo as análises dos autores:

$\checkmark \quad$ houve um aumento na resistência à compressão axial aos 7 e 28 dias. Entretanto, nas amostras com teores acima de $40 \%$ apresentaram uma redução nessa resistência possivelmente por conta da escória de cobre apresentar diâmetro máximo característico e granulometria mais grossa que a areia natural, altos teores de escória podem ter provocado a formação de uma quantidade maior de zonas de interfaces pasta-agregado, contribuindo para essa redução da resistência à compressão cos concretos;

$\checkmark \quad$ houve um aumento na resistência à tração por compressão diametral e por flexão à medida que há um aumento do teor de substituição de escória por areia até 40\%. Há um aumento da resistência à tração quanto menor for a relação água/cimento;

$\checkmark \quad$ os concretos com teor de substituição acima de $40 \%$ e relação água/cimento acima de 0,5 apresentaram uma redução da resistência à tração.

Shi et al. (2008) relatam que o tamanho das partículas da escória de cobre interfere no tempo de pega do concreto: quanto menor o tamanho do grão maior o atraso no tempo de pega. Interessantes trabalhos foram comentados pelos autores sobre a exsudação no concreto (bleeding). Ainda segundo os autores é recomendado usar menos de $40 \%$ de escória de cobre como substituição parcial do agregado para controlar a saída da água do concreto a menos de $51 / \mathrm{m}^{2}$. Em argamassa, a exsudação é comparativamente menor que usando areia natural. No entanto, o elevado peso específico e a superfície lisa das formas irregulares dos grãos da escória de cobre são eficazes na saída da água.

Nas pesquisas com escória de cobre pós-jateada em substituição ao agregado miúdo, Anjos (2015) conclui, entre outras, que o resíduo apresentou baixo índice de atividade pozolânica $(57,5 \%)$, melhoria na trabalhabilidade, menores absorção e índice de vazios para misturas com $80 \%$ de escória, queda na resistência à compressão axial e na resistência à tração por compressão diametral com incrementos do teor do resíduo, e, independente do teor, o concreto produzido foi mais deformável em relação ao concreto sem adição de escória.

Al-Jabri et al. (2016) avaliaram o efeito da escória de cobre como agregado fino nas propriedades do concreto e argamassa de cimento e concluíram que a escória proporciona uma melhor trabalhabilidade, o volume de vazios permeáveis 
diminui com a substituição de até $50 \%$ de escória, a resistência à compressão, à tração e a flexão diminuíam com teores acima de $50 \%$ de escória.

\section{- Outras aplicações}

Bharati e Chen (2016) trabalhando com argila mole, cimento e escória de cobre mostraram que, para uma trabalhabilidade constante, a resistência das misturas diminui ligeiramente com o acréscimo de escória para um menor tempo de cura e menor teor de cimento. Por outro lado, com maior tempo de cura e maior conteúdo de cimento, a resistência aumenta com o acréscimo de escória. Ainda, as alterações na resistência com o aumento da quantidade de escória dependem da combinação dos efeitos físicos, químicos e da redução do teor de cimento. Os autores acrescentam que a escória de cobre pode ser utilizada na substituição parcial no tratamento de argilas moles sem alterações nas propriedades de compressibilidade.

Estudos de Prasad e Ramana (2016) mostraram que a escória de cobre pode ser efetivamente utilizada como preenchimento estrutural de solo reforçado. Chun et al. (2005) realizaram estudos com aplicação da escória de cobre como uma areia substituindo a areia de estacas compactadas e concluíram que a escória se mostrou adequada como material de drenagem, apresenta ângulo de atrito maior do que a da areia e capacidade de suporte das estacas de escória foi superior à da areia.

\subsection{4 Impactos ambientais do uso da escória de cobre}

As principais análises químicas e mineralógicas não são suficientes para uma avaliação dos impactos ambientais, uma vez que é desconhecido se os componentes químicos vão ser lançados ao meio ambiente. Em se tratando dos efeitos sobre os recursos hídricos e do solo é de amplo interesse o conhecimento das concentrações dos compostos que podem ser lixiviados (Geiseler, 1996).

De acordo com Hartlén (1996), o principal impacto ambiental para o re-uso de materiais secundários é a lixiviação de substâncias perigosas para a água e o solo, tais como sais, metais e substâncias orgânicas. O fator dominante é o estado do produto, o qual define os fenômenos da lixiviação. Isso significa que os diferentes procedimentos de lixiviação têm de ser utilizados para diferentes tipos 
de resíduos e também para diferentes aplicações. Ainda de acordo com Hartlén (1996), as propriedades podem mudar ao longo do tempo por conta de fatores ambientais externos que podem alterar a lixiviação de um resíduo.

A NBR 10.004/2004 classifica os resíduos sólidos quanto aos seus riscos potencias ao meio ambiente e à saúde pública:

a) resíduos classe $\mathrm{I}$ - perigosos

b) resíduos classe II - não-perigosos

- resíduos classe II A - não-inertes

- resíduos classe II B - inertes

Para a classificação da escória de cobre proveniente da Caraíba Metais, no Estado da Bahia, Moura (2000) realizou ensaios de lixiviação (NBR 10.005/1987) ${ }^{7}$ e solubilização (NBR 10.006/1987) ${ }^{8}$, de acordo com as prescrições da NBR $10.004 / 1987^{9}$. Os resultados de tais ensaios estão apresentados na Tabela 2.6 e Tabela 2.7, respectivamente.

Tabela 2.6 Resultados dos ensaios de lixiviação (Moura, 2000).

\begin{tabular}{l|c|c}
\multicolumn{1}{c|}{ Elemento } & Quantidade & Limite (NBR 10.004/1987) \\
\hline Fenóis (mg/l)* & 0,05 & - \\
Fluoreto (mg/l)* & 0,16 & 150,0 \\
Arsênio $(\mathrm{mg} / \mathrm{l}) *$ & $<0,002$ & 5,0 \\
Cádmio (mg/l)* & $<0,01$ & 0,5 \\
Chumbo (mg/l)* & $<0,01$ & 5,0 \\
Cobre (mg/l)* & 0,69 & - \\
Cromo total (mg/l)* & $<0,05$ & 5,0 \\
Mercúrio (mg/l)* & $<0,0001$ & 0,1 \\
Prata (mg/l) & $<0,05$ & 5,0 \\
Vanádio (mg/l) & 0,04 & - \\
pH inicial & 5,6 & - \\
pH final & 5,0 & - \\
\hline
\end{tabular}

\footnotetext{
${ }^{7}$ ASSOCIAÇÃO BRASILEIRA DE NORMAS TÉCNICAS. NBR-10.005: lixiviação de resíduos. Rio de Janeiro, 1987.

8 _ NBR-10.006: Solubilidade de resíduo. Rio de Janeiro, 1987.

${ }^{9}$ Vale destacar que as normas referenciadas por Moura (2000) foram atualizadas a partir de 2004, conforme consta na NBR 10.004/2004.
} 
Tabela 2.7 Resultado dos ensaios de solubilização (Moura, 2000).

\begin{tabular}{|c|c|c|}
\hline Elemento & Quantidade & Limite (NBR 10.004/1987) \\
\hline Cloreto $(\mathrm{mg} / \mathrm{l}) *$ & $<1$ & 250 \\
\hline Nitrogênio nitrato (mg/l) & 0,05 & 10 \\
\hline Cianeto $(\mathrm{mg} / \mathrm{l}) *$ & $<0,01$ & 0,1 \\
\hline Dureza (mgCaCC3/l) & 16 & 500 \\
\hline Fenóis $(\mathrm{mg} / \mathrm{l}) *$ & $<0,001$ & 0,001 \\
\hline Fluoreto $(\mathrm{mg} / \mathrm{l}) *$ & 0,22 & 1,5 \\
\hline Sulfato (mg/l) & 11 & 400 \\
\hline Alumínio (mg/l) & $<1$ & 0,2 \\
\hline Arsênio $(\mathrm{mg} / \mathrm{l}) *$ & $<0,002$ & 0,05 \\
\hline Bário (mg/l) & $<1$ & 1,0 \\
\hline Cádmio (mg/l) * & $<0,001$ & 0,005 \\
\hline Chumbo $(\mathrm{mg} / \mathrm{l}) *$ & $<0,01$ & 0,05 \\
\hline Cobre (mg/l) & 0,5 & 1,0 \\
\hline Cromo total $(\mathrm{mg} / \mathrm{l}) *$ & $<0,05$ & 0,05 \\
\hline Ferro (mg/l) & 0,75 & 0,3 \\
\hline Mercúrio $(\mathrm{mg} / \mathrm{l})$ * & $<0,0001$ & 0,001 \\
\hline Manganês & $<0,05$ & 0,1 \\
\hline Zinco (mg/l) & 0,62 & 5 \\
\hline Prata * & $<0,05$ & 0,05 \\
\hline
\end{tabular}

Segundo Moura (2000), pode-se observar em ambas as tabelas que não foi nem lixiviado nem solubilizado nenhuma substância considerada tóxica acima dos limites da norma, verificando-se que a escória de cobre ensaiada pode ser classificada como Classe II - não-inerte, não apresentando riscos à saúde humana e ao meio ambiente.

Alter (2005) realizou uma avaliação, sob o ponto de vista ambiental, de 28 escórias de cobre proveniente dos EUA, Canadá e Chile, revelando que a quantidade de lixiviado está abaixo dos níveis regulamentares da agência de proteção ambiental dos EUA. Segundo uma análise estatística, o autor prevê com grande habilidade que a composição das escórias e seus lixiviados permaneceram como não perigosos o que faz incentivas a reutilização e a reciclagem das escórias de cobre.

Como uma das alternativas de aplicação da escória é a abrasiva para o preparo de superfícies de aço para pintura, por exemplo, a escória de cobre pós-jateada (granalha de cobre) é carregada de chumbo e metais pesados, classificando-a como um resíduo perigoso e, sem dúvida, a lixiviação dessas substâncias tóxicas em água 
subterrânea e solo é preocupante dada às centenas de toneladas de escória produzidas pelas fábricas anualmente (Zain et al., 2004).

Para Zain et al. (2004) a solubilização/estabilização é uma alternativa atraente para a remediação de materiais perigosos descartados inadequadamente e é eficaz quando esses compostos são unidos numa forma imune a lixiviação. Por essa alternativa, explicam os autores, o resíduo perigoso é envolvido por uma matriz sólida utilizando diferentes materiais de ligação, tais como cimento, pozolanas, argilas e polímeros que forma um sólido monolítico ou uma massa de solo com potencial para reduzir a lixiviação de constituintes perigosos do descarte de resíduos.

A partir dos estudos com a granalha, Zain et al. (2004) concluíram que a escória de cobre pode ser solidificada/estabilizada com segurança num sistema a base de cimento. A lixiviação dos íons de cobre, níquel, chumbo, zinco foi abaixo dos limites regulamentados pelos órgãos de qualidade ambiental da Malásia. A argamassa que incorpora escória de cobre até $10 \%$ de substituição é, portanto, segura no que diz respeito à lixiviação desses íons metálicos.

É importante destacar do trabalho desses autores que a resistência à compressão caiu com a substituição do cimento pela escória. Essa baixa resistência pode ser atribuída ao retardo na hidratação do cimento devido à presença dos metais pesados na escória de cobre. Além disso, as partículas finas da escória fornecem maiores superfícies específicas para serem envolvidas pelo cimento.

\section{5}

\section{Considerações Finais}

A revisão bibliográfica apresentada neste capítulo possibilitou o conhecimento de conceitos sobre os métodos de estabilização de solo, com mais detalhes na estabilização química com cimento, tendo como função principal melhorar a capacidade de suporte do solo. O capítulo também apresentou um breve histórico, características e aplicações do resíduo objeto da pesquisa.

No capítulo seguinte são apresentados os materiais e a metodologia utilizada na presente pesquisa. 


\section{3 \\ Materiais e Métodos}

\section{1} Solo

Nesta pesquisa foi utilizado o solo de uma jazida localizada no Município de São Cristóvão, Estado de Sergipe, próximo à capital Aracaju. Para a escolha dessa jazida foi levado em consideração o volume de material e a qualidade do solo, uma vez que um dos objetivos desta pesquisa é analisar a estabilização do solo com adição de cimento Portland e comparar com a adição de escória de cobre pósjateada. Além disso, como a jazida situa-se próxima à cidade de Aracaju (30km) e, portanto, a pouca distância de transporte, ainda se torna viável economicamente a extração de solo para obras de pavimentação na capital.

Nas obras de pavimentação realizadas em Aracaju, as base e sub-base foram executadas com cascalho branco, assim denominado um material rico em pedregulho com pouco material fino, em algumas ruas foi utilizada a brita corrida e, ainda, misturas de solos com granulometrias diferentes. A espessura para tais camadas é de $20 \mathrm{~cm}$, sobre um subleito regularizado. Quanto ao revestimento, o concreto usinado a quente é utilizado com espessura média de $4 \mathrm{~cm}$.

O solo foi identificado de acordo com o nome da jazida, assim denominado jazida Aningas - amostra aningas. Por uma análise tátil-visual, o solo predomina uma mistura de areia e argila com presença de pedregulho.

A coleta foi realizada no próprio horizonte superficial, sem necessidade de escavações, pois em toda a jazida a exploração do material havia sido recente. Com auxílio de picareta e pá, uma primeira coleta de aproximadamente $400 \mathrm{~kg}$ foi acondicionada em sacos de nylon para o transporte até o Laboratório de Geotecnia e Pavimentação (GeoPav) da Universidade Federal de Sergipe (UFS). No decorrer dos ensaios, diante do número de repetições de ensaios, foi necessário realizar uma nova coleta, sendo acondicionado cerca de $250 \mathrm{~kg}$ de solo a mais.

Segundo o levantamento de reconhecimento de solos da Embrapa (1999), o solo estudado pertence à Formação Barreiras, apresentando-se sob a classe PV22, 
conforme o mapa de Classificação dos Solos da Secretaria de Estado do Meio Ambiente e dos Recursos Hídricos do Governo do Estado de Sergipe:

- PV22 - associação de Podzólico Vermelho Amarelo plíntico raso ou não raso, textura média cascalhanta/argilosa, seixosa e concrecionária, relevo suave ondulado, ondulado e forte ondulado + Podzólico Vermelho Amarelo de textura média/argilosa, relevo suave ondulado e ondulado. Ambos com argila de baixa atividade $(\mathrm{Tb}$ ) com um horizonte (A moderado) mineral de carbono $\geq 5.8 \mathrm{~g} / \mathrm{kg}$, mas com demais características morfológicas, de alguma forma, discrepantes das requeridas pelos demais horizontes minerais superficiais. Ambos também apresentam fase campo cerrado, pois trata-se de áreas com grandes domínios de um substrato rasteiro graminóide, compreendendo moitas esparsas ou pequenas "ilhas" com a vegetação de cerrado (EMBRAPA, 1999).

A jazida Aningas localiza-se no povoado de mesmo nome, situado no município de São Cristóvão, cerca de $30 \mathrm{~km}$ da entrada oeste do município de Aracaju. Essa jazida está às margens da BR-101, próxima ao posto da Polícia Rodoviária Federal, sendo o seu acesso praticamente feito por estrada pavimentada (Figura 3.1).

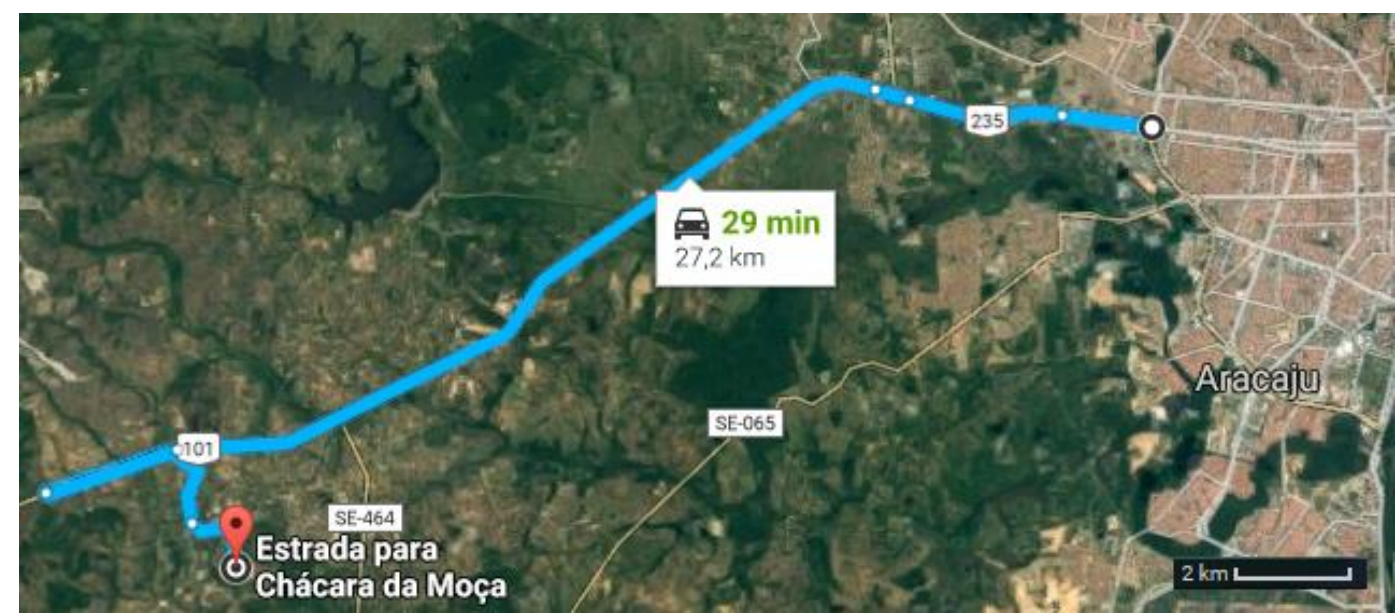

Figura 3.1 Localização da jazida Aningas.

As coordenadas geográficas e UTM do ponto de coleta da amostra são apresentadas na Tabela 3.1. A Figura 3.2 mostra uma visão parcial da jazida aningas, bem como o ponto de coleta. Observa-se no material a presença de pedregulho e sua coloração amarelada e predominantemente avermelhada. 
Tabela 3.1 Coordenadas do ponto de coleta na jazida Aningas.

\begin{tabular}{c|c}
\hline Coordenadas geográficas & Coordenadas UTM (datum Sirgas 2000** \\
\hline W $37^{\circ} 14^{\prime} 16,3^{\prime}$, & X: $692508.343269(\mathrm{~m})$ \\
S $10^{\circ} 58^{\prime} 36^{\prime}$, & Y: $8785988.89172(\mathrm{~m})$
\end{tabular}

*A transformação para estas coordenadas UTM foi realizada através do site www.dpi.inpe.br

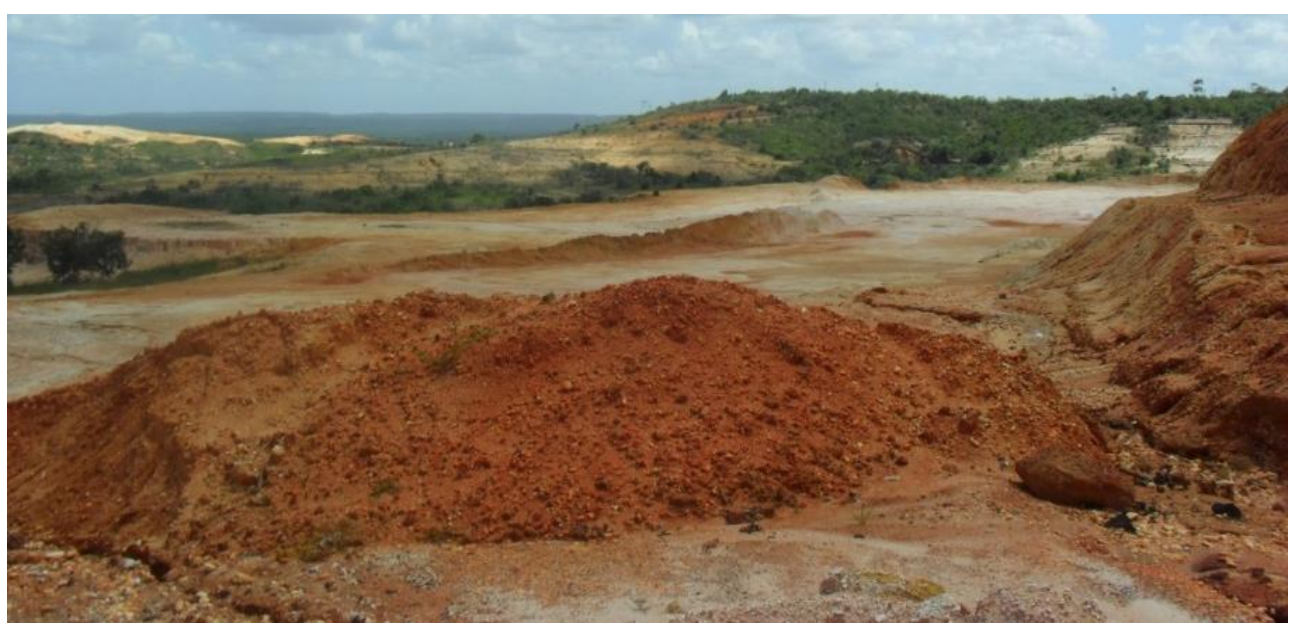

Figura 3.2 Visão parcial da jazida Aningas.

\section{2}

\section{Escória de cobre pós-jateada}

A escória de cobre utilizada nesse estudo foi obtida após o processo de jateamento a seco de tanque de armazenamento de petróleo, como ilustrado na Figura 3.3. Após três ciclos de jateamento, a escória foi armazenada provisoriamente no canteiro de obras de manutenção geral do tanque, de onde foi coletada e levada para o laboratório.
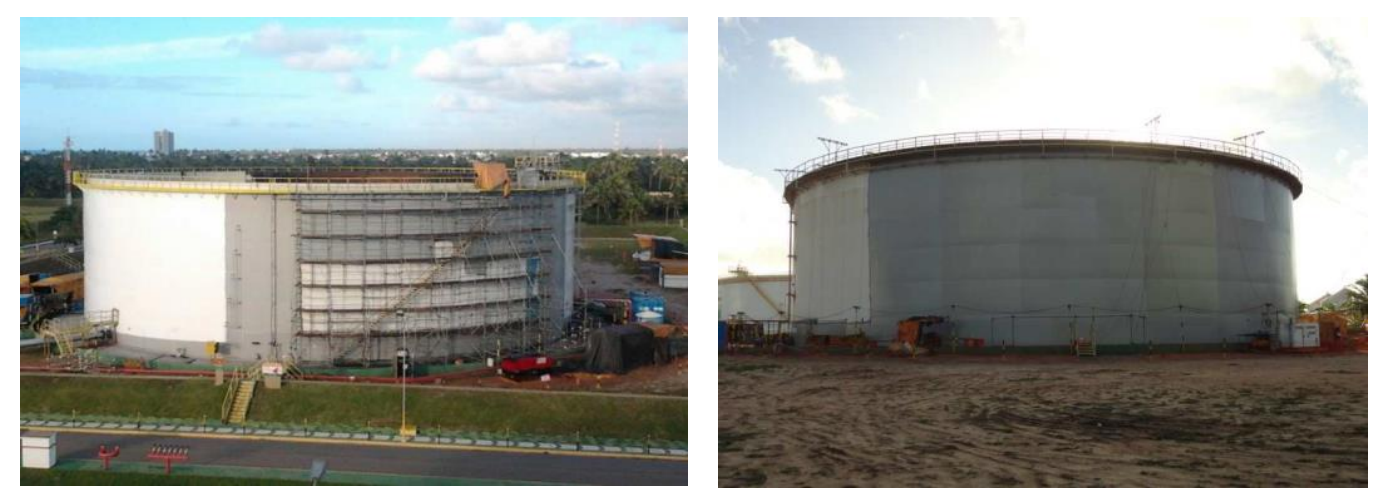

Figura 3.3 Tanque em manutenção - face externa (ANJOS, 2015). 
A Figura 3.4 mostra a escória de cobre antes do processo de jateamento (granalha de cobre) e a escória após o jateamento (granalha batida de cobre). Ao total, estima-se que, em toda a manutenção dos tanques de armazenamento, foram produzidas cerca de 31,6 t de granalha batida de cobre.

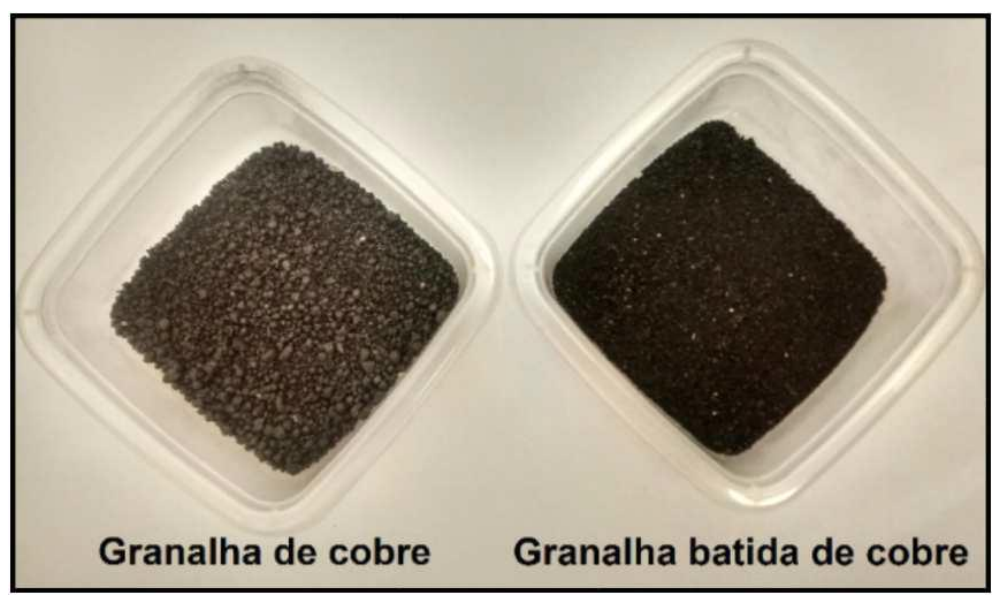

Figura 3.4 Escória de cobre antes e após o processo de jateamento (ANJOS, 2015).

Como uma forma mais didática, será denominado nesse estudo o termo escória para a granalha batida de cobre, isto é, a escória de cobre aqui referida e usada nas pesquisas é a escória pós-jateada. A Figura 3.5 mostra a escória usada nas misturas com solo e cimento Portland. Os teores adicionados às misturas sempre se referem à massa de solo seco.

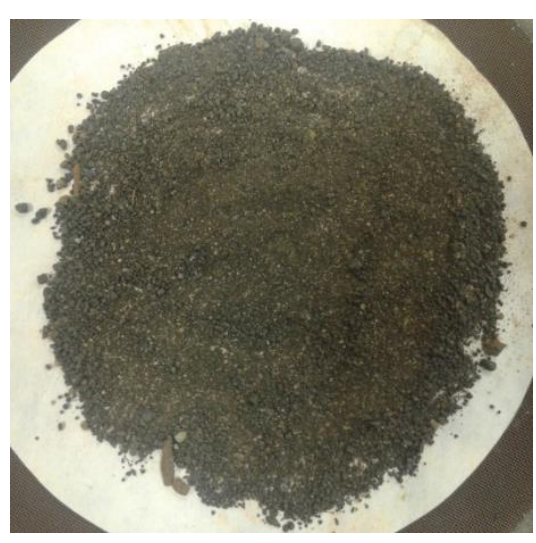

Figura 3.5 Amostra de escória de cobre utilizada na pesquisa. 


\section{3 \\ Cimento Portland}

O cimento Portland utilizado nessa pesquisa é do tipo CP V - ARI - Cimento Portland de alta resistência inicial, de fabricação da Mizu Cimentos. A opção por esse tipo de cimento está baseada na sua composição química que apresenta menores adições na mistura durante a sua fabricação, além de garantir uma alta resistência inicial da mistura. De acordo com a NBR 5733/1991 ${ }^{10}$, a composição para o CP V-ARI varia de 100-95\% de clínquer e sulfatos de cálcio e 0-5\% de material carbonático. Em termos comparativos, o cimento $\mathrm{CP}$ II comumente utilizado na construção civil apresenta, além do clínquer e sulfatos de cálcio, diferentes porcentagens de escória granulada de alto-forno, material pozolânico e material carbonático (NBR 11578/1991 ${ }^{11}$ ).

Os teores de cimento adicionados às misturas foram sempre referentes à massa de solo seco e à massa de solo e escória de cobre secos. O período de cura de 7 dias foi realizado em câmara úmida.

\section{4 \\ Ensaios}

A amostra de solo coletada foi levada ao GeoPav e preparada para os respectivos ensaios de caracterização (umidade higroscópica, granulometria, densidade real, limite de liquidez e limite de plasticidade), compactação, índice de suporte califórnia - ISC, resistência à compressão simples - RCS, ensaio triaxial de carga repetida (determinação do módulo de resiliência - MR), resistência à tração, durabilidade, permeabilidade, caracterização mineralógica (difração de raios X e fluorescência de raios X) e lixiviação e solubilização. O Quadro 3.1 apresenta um resumo dos ensaios realizados no programa experimental para o desenvolvimento da pesquisa.

A princípio foi seguida a norma DNER - ME 041/94 Solos - preparação de amostras para ensaios de caracterização, com as operações de secagem ao ar,

\footnotetext{
${ }^{10}$ ASSOCIAÇÃO BRASILEIRA DE NORMAS TÉCNICAS. NBR 5733: cimento Portland de alta resistência inicial. Rio de Janeiro, 1991.

${ }^{11}$ ASSOCIAÇÃO BRASILEIRA DE NORMAS TÉCNICAS. NBR 11578: cimento Portland composto. Rio de Janeiro, 1991.
} 
destorroamento e o quarteamento das amostras, conforme a sequência da Figura 3.6 .

Quadro 3.1 Ensaios realizados no programa experimental.

\begin{tabular}{|c|c|c|c|c|c|}
\hline Ensaio & Solo & Escória & $\begin{array}{l}\text { Solo - } \\
\text { Cimento }\end{array}$ & $\begin{array}{l}\text { Solo - } \\
\text { Escória }\end{array}$ & $\begin{array}{c}\text { Solo - } \\
\text { Escória - } \\
\text { Cimento }\end{array}$ \\
\hline Caracterização geotécnica & $*$ & $*$ & & $*$ & \\
\hline Compactação & $*$ & & $*$ & $*$ & $*$ \\
\hline Índice de Suporte Califórnia & $*$ & & & & \\
\hline Resistência à Compressão Simples & $*$ & & $*$ & $*$ & $*$ \\
\hline Módulo de Resiliência & $*$ & & $*$ & & $*$ \\
\hline Resistência à tração & $*$ & & $*$ & $*$ & $*$ \\
\hline Durabilidade & & & $*$ & & $*$ \\
\hline Permeabilidade & $*$ & & & $*$ & $*$ \\
\hline Microscopia eletrônica de varredura & & $*$ & & $*$ & $*$ \\
\hline Difração de raios X & $*$ & $*$ & & & \\
\hline Fluorescência de raios $\mathrm{X}$ & $*$ & $*$ & & & \\
\hline Lixiviação e solubilização & & $*$ & & & $*$ \\
\hline
\end{tabular}

(a)

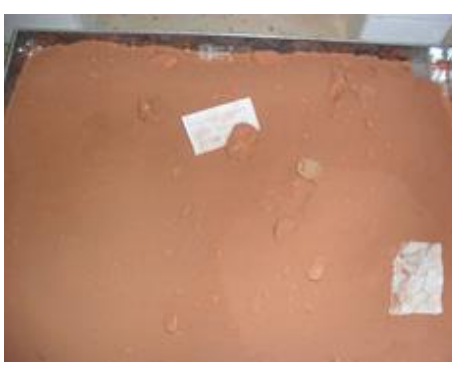

(b)

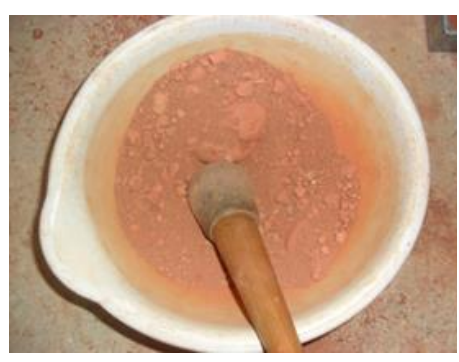

(c)

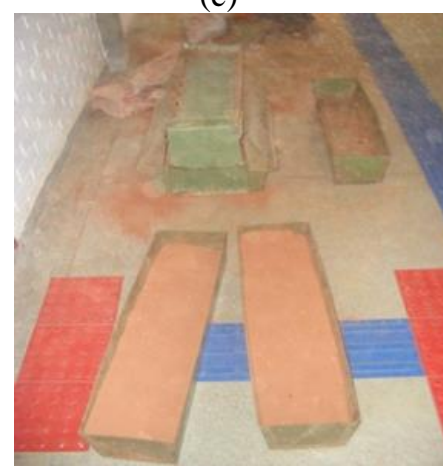

Figura 3.6 Secagem (a), destorroamento (b) e quarteamento (c).

\subsection{1}

\section{Caracterização}

Para o conhecimento, identificação, diferenciação e classificação os seguintes ensaios foram realizados, segundo as normas DNER:

ME 093/94 - Solos - determinação da densidade real

ME 051/94 - Solos - análise granulométrica

ME 082/94 - Solos - determinação do limite de liquidez

ME 122/94 - Solos - determinação do limite de plasticidade 
Na classificação seguiu os procedimentos da TRB (Transportation Research Board) e a USCS (Unified Soil Classification System).

\subsection{2}

\section{Compactação}

O ensaio de compactação seguiu a norma DNER:

ME 129/94 - Solos - compactação utilizando amostras não trabalhadas

Destaca-se que a energia de compactação utilizada em todos os ensaios é a intermediária (Método B da referida norma) com 26 golpes por camada.

Apesar de a norma DNER-ME 216/94 (solo-cimento - determinação da relação entre o teor de umidade e a massa específica aparente) descrever a energia normal para solo-cimento, foi utilizada a energia intermediária, uma vez que a adição de escória de cobre pós-jateada modifica a granulometria do solo, por meio da estabilização granulométrica, e, segundo a norma DNIT 139/2010-ES (pavimentação - sub-base estabilizada granulometricamente), a energia mínima requerida é a intermediária.

\subsection{3}

\section{Índice de Suporte Califórnia - ISC}

A partir dos parâmetros obtidos do ensaio de compactação, massa específica aparente seca máxima e umidade ótima, corpos de prova são moldados para determinação do valor de suporte do solo estudado. Para este ensaio foi seguida a norma DNER:

ME 049/94 - Solos - determinação do índice de suporte Califórnia utilizando amostras não trabalhadas

A prensa utilizada foi o modelo I-2001-A Prensa Marshall Elétrica com anel dinamométrico com capacidade de $5.000 \mathrm{Kgf}$ e extensômetro de resolução 0,001 mm de fabricação da CONTENCO Ind. e Com. LTDA.

\subsection{4}

Resistência à compressão simples - RCS

O ensaio de resistência à compressão simples seguiu as normas DNER:

$\checkmark$ ME 202/94 - Solo-cimento - moldagem e cura de corpos-de-prova cilíndricos 
ME 201/94 - Solo-cimento - compressão axial de corpos-de-prova cilíndricos

A princípio foram utilizadas essas normas para o solo puro com o objetivo de comparar os valores de resistência quando misturado ao cimento Portland e a escória de cobre. Portanto, os valores obtidos nesse ensaio com solo puro serviram de referência para mostrar a evolução do ganho de resistência ao se adicionar percentagens do aditivo e da escória em relação ao peso seco de solo.

Vale destacar que, segundo o item 3.3 da norma DNER ME-201/94, os corpos de prova destinados à dosagem do solo-cimento ou ao controle de obra, após o período de cura especificado, são submetidos à imersão em água por 4 horas. No entanto, para o solo puro essa imersão não foi realizada, uma vez após o período de cura de 7 dias, os corpos de prova perderam umidade e ao imergir em água, os mesmos se desfaziam. Os corpos de prova das misturas sem cimento foram curados por 7 dias em câmara úmida e, em seguida, submetidos ao ensaio de resistência. Já os corpos de prova com cimento, além dessa mesma cura, foram imersos em água por 4 horas antes do ensaio de resistência.

A prensa utilizada no início dos ensaios foi produzida pela EMIC Equipamentos e Sistemas de Ensaio modelo Máquina Universal de Ensaios, eletrodinâmica e micropocessada DL 20000, acompanhada da licença de uso do software TESC programa para automação de ensaios, conforme mostrada na Figura 3.7a, pertencente ao Laboratório de Materiais de Construção e Estrutura do Departamento de Engenharia Civil da UFS. Durante a execução dos ensaios, essa prensa apresentou problemas técnicos ficando inoperante. A continuação dos ensaios foi realizada na prensa INSTRON modelo $3385 \mathrm{H}$ acompanhada do software Bluehill 3, como mostrada na Figura 3.7b, pertencente ao Laboratório de Ensaios Mecânicos do Departamento de Engenharia de Materiais da UFS. 
(a)

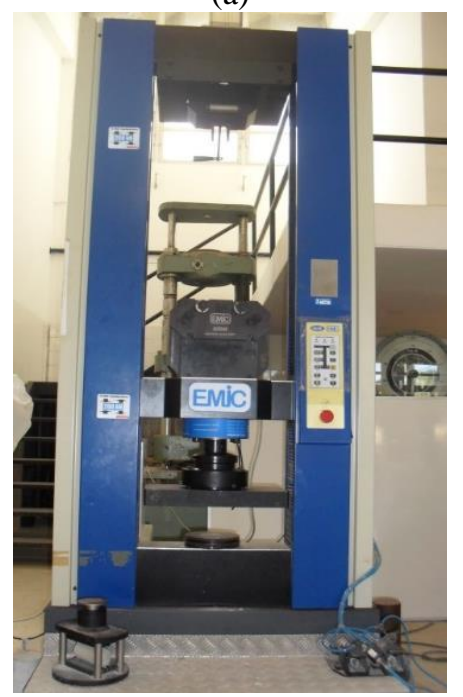

(b)

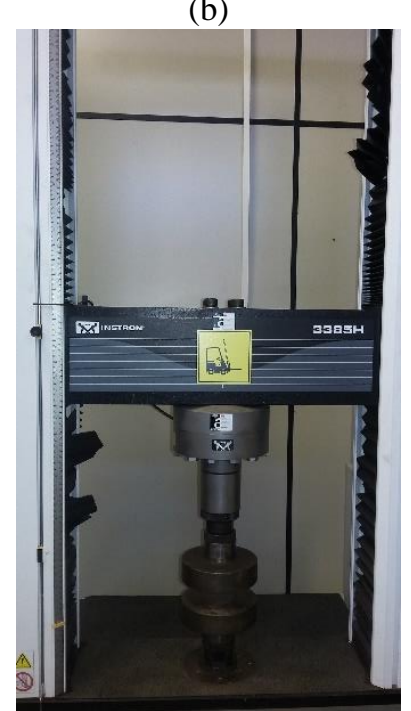

Figura 3.7 Prensa de resistência à compressão simples EMIC DL 20000 (a) e INSTRON 3385H (b).

\section{4 .5}

\section{Módulo de resiliência - MR}

O ensaio triaxial de carga repetida para determinação do módulo de resiliência seguiu a norma DNER:

ME 134/2010 - Pavimentação - Solos - Determinação do módulo de resiliência

O equipamento utilizado pertencente ao laboratório GeoPav, foi o SIEMBS Sistema Integrado de Ensaios para Misturas Betuminosas e Solos, versão 1.1 fabricado pela empresa ARMTEC - Tecnologia em Robótica (Figura 3.8). O sistema de carregamento é pneumático com a força vertical transmitida alternada e rapidamente ao corpo de prova pelo topo por meio de um pistão. Nesse sistema, o ar comprimido ao passar por um regulador de pressão atua diretamente sobre a válvula ligada a um cilindro de pressão que, sendo aberta, a pressão do ar é transmitida ao corpo de prova e ao ser fechada a válvula, a pressão deixa de atuar. O tempo de aplicação de carga e a frequência do carregamento são controlados por um temporizador eletrônico. Esse tipo de carregamento procura simular o efeito sobre a tensão vertical nas camadas do pavimento, devido à passagem de uma roda de veículo. 
(a)

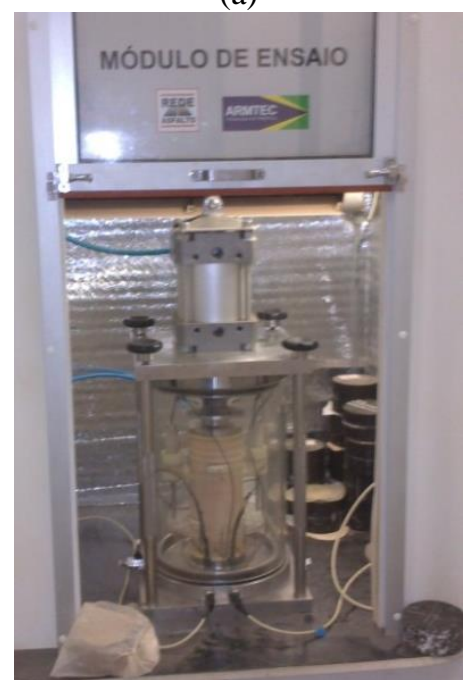

(b)

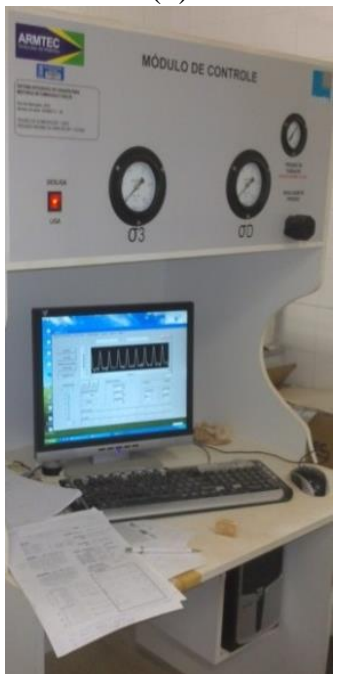

Figura 3.8 Equipamento para determinação do módulo de resiliência do GeoPav: (a) módulo de ensaio e (b) módulo de controle.

- Preparação e moldagem dos corpos-de-prova

Depois da secagem ao ar, destorroamento e quarteamento, toma-se uma amostra de $4000 \mathrm{~g}$, suficiente para preencher o molde cilíndrico. Acrescenta-se a água necessária para atingir a umidade ótima, segundo os resultados prévios do ensaio de compactação. Essa massa de solo após homogeneização com água foi embalada em sacos plásticos e levada à câmara úmida até a constância de massa, para determinar a umidade higroscópica.

Após determinação da umidade, procede-se a compactação do solo num molde cilíndrico bipartido de dimensões 100 x 200 mm e untado com vaselina. A compactação foi realizada com soquete de $4.536 \mathrm{~g}$, em cinco camadas com vinte golpes cada uma das camadas, representando a energia Proctor intermediária. Quando compactados, os corpos de prova foram levados à câmara úmida para a cura por um período de 7 dias (Figura 3.9).

Essa preparação e a moldagem foram as mesmas em todas as etapas do trabalho para o solo puro e as misturas com solo e escória e com solo, escória e cimento. 
(a)

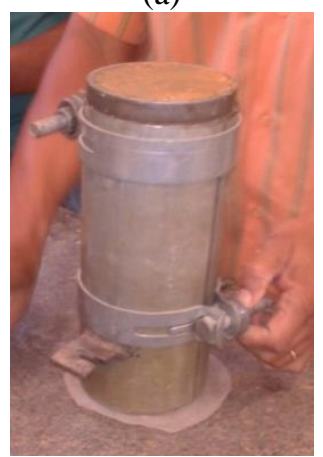

(b)

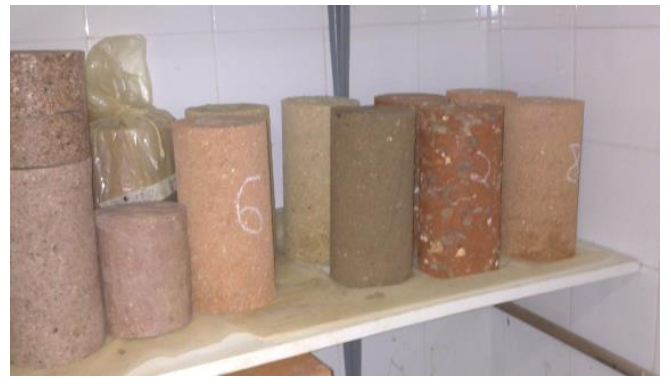

Figura 3.9 Corpos de prova para ensaio de MR: (a) moldagem em cilindro bipartido e (b) cura em câmara úmida.

- Montagem para o ensaio

Após o período de cura, os corpos de prova foram envolvidos por duas membranas de borracha lisas e sem furos, seguida da fixação de dois anéis que servem de suporte para o par de LVDTs, como mostrado na Figura 3.10.

(a)

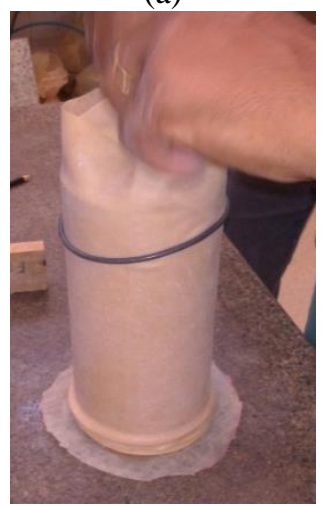

(b)

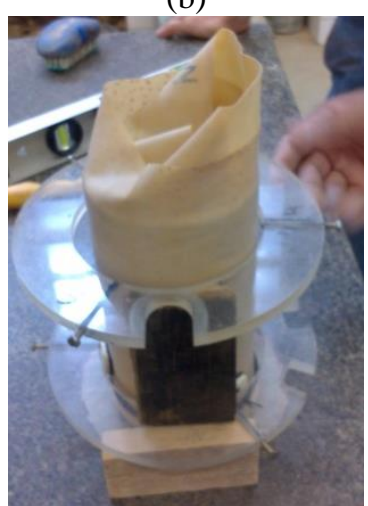

Figura 3.10 Montagem do corpo de prova para o ensaio: (a) colocação das membranas e (b) anéis de suporte para o par de LVDTs.

O conjunto é assentado na base da célula triaxial e posiciona-se o cabeçote no topo do corpo de prova. O par de LVDTs é fixado nos anéis de suporte sendo ambos ajustados aproximadamente à mesma altura para as leituras das deformações. Realizados todos os ajustes e fixação dos LVDTs, coloca-se o invólucro cilíndrico e a placa superior de vedação lacra totalmente a célula triaxial. A sequência da Figura 3.11 apresenta os procedimentos de montagem do corpo de prova na célula triaxial para realização do ensaio. 
(a)

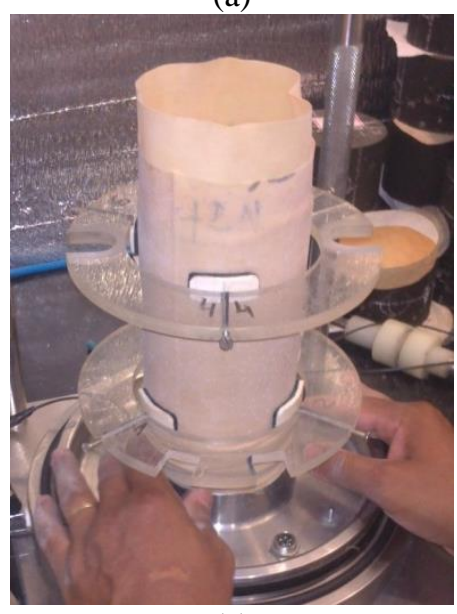

(c)

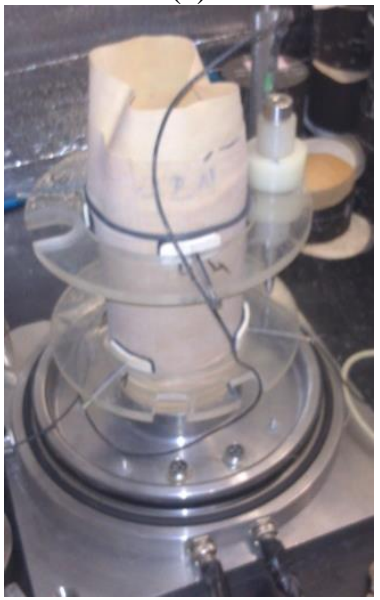

(b)

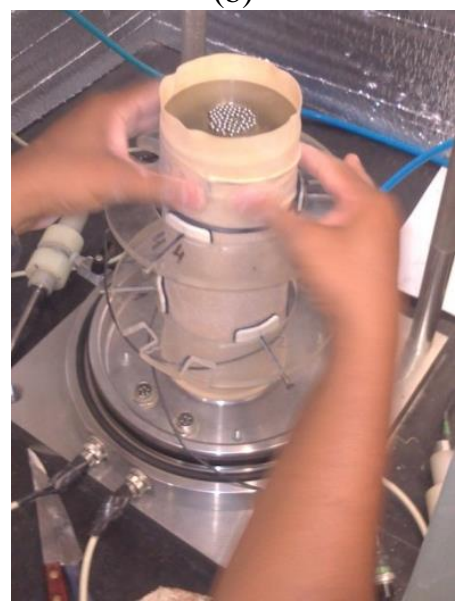

(d)

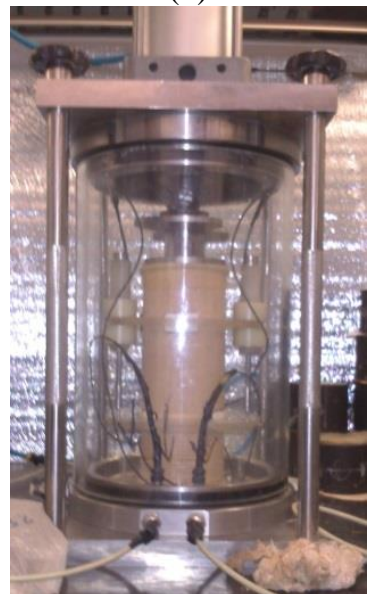

Figura 3.11 Corpo de prova na célula triaxial para realização do ensaio: (a) assentamento na base, (b) posicionamento do cabeçote, (c) fixação dos LVDTs nos anéis de suporte e (d) vedação da célula triaxial.

- Aplicação das cargas

Inicialmente executa-se a fase de condicionamento que visa eliminar as grandes deformações plásticas (permanentes) que ocorrem nas primeiras aplicações da tensão desvio e de reduzir o efeito da história de tensões no valor do módulo de resiliência. A frequência das cargas repetidas é de $1 \mathrm{~Hz}$ (60 ciclos por minuto) e duração de 1,0 segundo, sendo 0,10 segundos para aplicação da carga e 0,9 segundo de repouso para aplicação da carga seguinte. São aplicadas 200 repetições para cada tensão desvio, segundo a Tabela 3.2.

Finalizada a fase de condicionamento, inicia-se o procedimento para determinação do módulo de resiliência com aplicação da sequência de 18 pares de tensões, conforme apresentado na Tabela 3.3. 
Tabela 3.2 Sequência de tensões para fase de condicionamento (DNER - ME - 134/2010).

\begin{tabular}{c|c|c}
\hline Tensão confinante $\sigma_{3}(\mathrm{KPa})$ & Tensão desvio $\sigma_{\mathrm{d}}(\mathrm{KPa})$ & Razão de tensões $\sigma_{1} / \sigma_{3}$ \\
\hline 68,9 & 68,9 & 2 \\
68,9 & 206,8 & 4 \\
102.9 & 309,0 & 4 \\
\hline
\end{tabular}

Tabela 3.3 Sequência de tensões para determinação do módulo de resiliência (DNER - ME 134/2010).

\begin{tabular}{c|c|c}
\hline$\sigma_{3}(\mathrm{KPa})$ & $\sigma_{\mathrm{d}}(\mathrm{KPa})$ & $\sigma_{1} / \sigma_{3}$ \\
\hline \multirow{3}{*}{20,7} & 20,7 & 2 \\
& 41,4 & 3 \\
& 62,1 & 4 \\
\hline \multirow{3}{*}{34,5} & 34,5 & 2 \\
& 68,9 & 3 \\
& 102,9 & 4 \\
\hline \multirow{3}{*}{50,4} & 50,4 & 2 \\
& 102,9 & 3 \\
& 155,2 & 4 \\
\hline
\end{tabular}

\begin{tabular}{c|c|c}
\hline$\sigma_{3}(\mathrm{KPa})$ & $\sigma_{\mathrm{d}}(\mathrm{KPa})$ & $\sigma_{1} / \sigma_{3}$ \\
\hline \multirow{3}{*}{68,9} & 68,9 & 2 \\
& 137,9 & 3 \\
& 206,8 & 4 \\
\hline \multirow{3}{*}{102,9} & 102,9 & 2 \\
& 206,8 & 3 \\
& 309,0 & 4 \\
\hline \multirow{3}{*}{137,9} & 137,9 & 2 \\
& 274,7 & 3 \\
& 412,0 & 4 \\
\hline
\end{tabular}

- Modelo para análise do módulo de resiliência

Para a modelagem do MR com o estado de tensão foram aplicados três modelos de análise, cada um relaciona-se com as tensões confinantes e desvio de forma isolada, como esquematizada na Equação 3.1 e na Equação 3.2, ou simultânea com $\sigma_{3}$ e $\sigma_{d}$ apresentada pela Equação 3.3.

$$
\begin{gathered}
\mathrm{MR}=\mathrm{k}_{1} \cdot \sigma_{3}{ }^{\mathrm{k}}{ }_{2} \\
\mathrm{MR}=\mathrm{k}_{1} \cdot \sigma_{\mathrm{d}}{ }^{\mathrm{k}} \\
\mathrm{MR}=\mathrm{k}_{1} \cdot \sigma_{3}{ }_{2}{ }_{2} \cdot \sigma_{\mathrm{d}}{ }_{3}
\end{gathered}
$$

onde:

$$
\begin{array}{ll}
\text { MR }- \text { módulo de resiliência } & \sigma_{\mathrm{d}}-\text { tensão desvio } \\
\sigma_{3}-\text { tensão confinante } & \mathrm{k}_{\mathrm{i}}-\text { constante de regressão do modelo }
\end{array}
$$

Para o tratamento dos dados matemáticos foi utilizado o programa Excel para os parâmetros das Equações 3.1 e 3.2 e no modelo representado pela Equação 3.3, o programa utilizado foi o LabFit Ajuste de Curvas, desenvolvido por pesquisadores da UFCG (SILVA, W. e SILVA, C. 2003). 


\subsection{6 Resistência à tração por compressão diametral}

Como há uma simplicidade, o procedimento do ensaio é similar ao realizado em corpos de prova de misturas asfálticas e como não há uma norma específica para solo, a realização do ensaio de tração seguiu a norma DNER:

$\checkmark$ ME 138/94 Misturas betuminosas - determinação da resistência à tração por compressão diametral

Os corpos de prova foram moldados de forma cilíndrica com altura média de $5,5 \mathrm{~cm}$ e diâmetro médio de $10 \mathrm{~cm}$, numa energia intermediária, seguindo o mesmo padrão dos ensaios mecânicos e alguns procedimentos foram seguidos:

- fixação da altura do corpo de prova $(5,5 \mathrm{~cm})$;

- cálculo da quantidade de solo através da massa específica aparente seca máxima e das dimensões do molde;

- série de golpes até chegar na altura fixada.

Após a moldagem, os corpos de prova foram submetidos à cura por 7 dias (Figura 3.12) em câmara úmida.

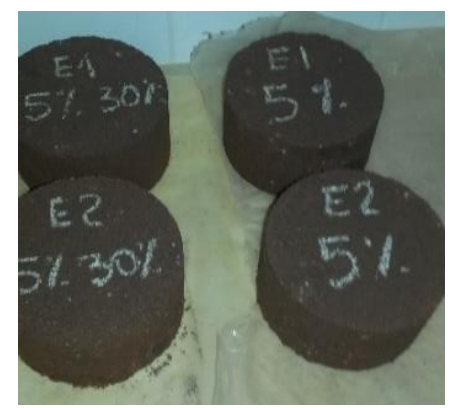

Figura 3.12 Corpos de prova submetidos à cura em câmara úmida por 7 dias.

A prensa utilizada para romper os corpos de prova foi o modelo I-2001-A Prensa Marshall Elétrica com anel dinamométrico com capacidade de $5.000 \mathrm{Kgf} \mathrm{e}$ extensômetro de resolução 0,001 mm de fabricação da CONTENCO Ind. e Com. LTDA, conforme apresentada na Figura 3.13. 


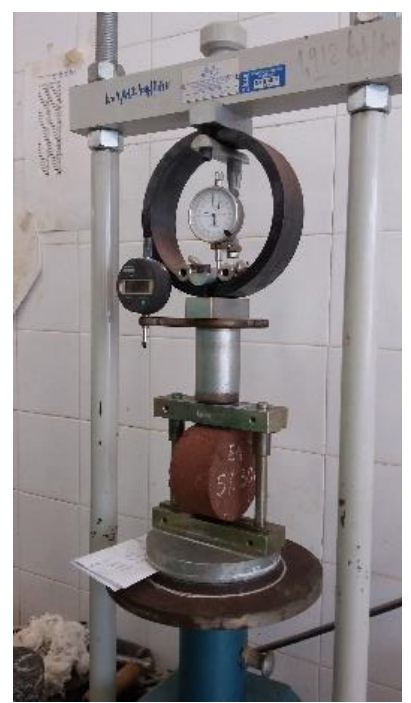

Figura 3.13 Prensa de rompimento à tração dos corpos de prova.

\subsection{7 Durabilidade}

Para avaliar a durabilidade de solo-cimento, através da determinação da perda de massa de corpos de prova cilíndricos, quando submetidos a determinados ciclos de molhagem e secagem, foi utilizada a norma DNER:

ME 203/94 - Solo-cimento - determinação da durabilidade através da perda de massa por molhagem e secagem.

A mesma norma foi utilizada para realizar o ensaio em corpos de provas com a mistura de solo, escória de cobre e cimento Portland. Em todos eles, os corpos de provas foram moldados segundo os parâmetros obtidos do ensaio de compactação, deixados em cura por sete dias e, em seguida, iniciado os 12 ciclos de molhagem, por imersão em água por $5 \mathrm{~h}$, e secagem em estufa elétrica a $70 \pm 2{ }^{\circ} \mathrm{C}$ por $42 \mathrm{~h}$.

\subsection{8}

\section{Ensaio de permeabilidade}

A determinação do coeficiente de permeabilidade foi realizada pelo ensaio de carga variável. O método consiste em conectar um tubo de pequeno diâmetro ao permeâmetro onde está instalada a amostra de solo. Esse tubo é preenchido com água e o ensaio inicia quando o nível d'água atinge um determinado referencial. Os tempos necessários para atingir outras posições mais baixas são anotados. A Equação 3.4 foi utilizada para determinação do coeficiente de permeabilidade. 


$$
k=2,303 \cdot \frac{a \cdot L}{A \cdot \Delta t} \cdot \log \frac{h_{1}}{h_{2}}
$$

onde:
a - área da bureta
$\Delta \mathrm{t}$ - variação de tempo entre as leituras
$\mathrm{L}$ - comprimento da amostra de solo
$\mathrm{h}_{1}$ - carga no instante 1
A - área da amostra de solo
$\mathrm{h}_{2}$ - carga no instante 2

Para referir o coeficiente de permeabilidade calculado à temperatura de $20{ }^{\circ} \mathrm{C}$ a Equação 3.5 foi utilizada. A relação $\left(\mathrm{R}_{\mathrm{T}}\right)$ entre a viscosidade da água na temperatura de ensaio e a viscosidade da água a $20{ }^{\circ} \mathrm{C}$, foi obtida da norma NBR $14545 / 2000$.

$$
k_{20}=R_{T} \cdot k
$$

onde:

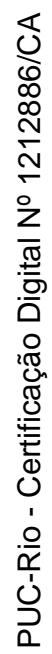
k20 - coeficiente de permeabilidade referido à temperatura de $20^{\circ} \mathrm{C}$
$\mathrm{R}_{\mathrm{T}}$ - relação entre a viscosidade da água na temperatura de ensaio e a viscosidade da água a $20{ }^{\circ} \mathrm{C}$
$\mathrm{k}$ - coeficiente de permeabilidade calculado

A Figura 3.14 mostra o ensaio de permeabilidade em andamento.

Figura 3.14 Ensaio de permeabilidade de carga variável. 


\section{4 .9 \\ Dosagem físico-química}

O procedimento para dosagem seguiu a descrição de Casanova et al. (1992). A metodologia dessa dosagem serviu também para a dosagem com a escória de cobre pós-jateada.

\section{Materiais necessários}

$\checkmark$ balança com capacidade máxima para $2 \mathrm{~kg}$ e precisão de leitura igual a 0,1 $\mathrm{g}$;

$\checkmark$ provetas de vidro com $250 \mathrm{~cm}^{3}$ de volume, graduadas de $2 \mathrm{em} 2 \mathrm{~cm}^{3}$;

$\checkmark$ bastão de plástico rígido;

$\checkmark$ frasco lavador

\section{Procedimento}

1. utilizar em média sete provetas de $250 \mathrm{ml}$ marcando-as com as porcentagens de cimento $(0 \%, 3 \%, 5 \%$...);

2. pesar 20,0 g de solo, seco ao ar, destorroado e passado na peneira $\mathrm{n}^{\circ} 10$, e colocar em cada proveta;

3. adicionar as quantidades crescentes de cimento, em porcentagens por peso de solo, nas respectivas provetas;

4. misturar o solo e o cimento ainda secos, agitando a proveta ${ }^{12}$,

5. colocar aproximadamente $50 \mathrm{ml}$ de água destilada e agitar a proveta até conseguir a homogeneização completa da mistura;

6. completar o volume para $100 \mathrm{ml}$, lavando as paredes da proveta e colocar em repouso até o dia seguinte;

\section{Observação:}

- Em havendo dispersão do solo na água (proveta 0\%), adicionar algumas gotas de $\mathrm{HCl}$ (ácido clorídrico ou muriático) antes de completar o volume, a fim de flocular a argila dispersa, permitindo assim, uma melhor definição da leitura.

- É necessário que o lugar de apoio das provetas não sofra qualquer tipo de vibração.

\footnotetext{
${ }^{12}$ Para uma perfeita homogeneização da mistura solo-cimento-escória, optou-se por realizar a mistura a seco num recipiente plástico e depois introduzido a mistura nas respectivas provetas.
} 
7. no dia seguinte agitar a mistura com auxilio do bastão até ficar bem homogênea. Após no mínimo 2 horas fazer a leitura do volume ocupado pelo sedimento. Agite a suspensão com o bastão fazendo movimentos circulares firmes e rápidos mantendo sempre a mesma cadência, durante 30 $\mathrm{s}$

8. no terceiro dia agitar novamente e ler os volumes no mínimo 2 horas após (repetição do procedimento $\mathrm{n}^{\circ} 7$ );

9. repetir esta operação todos os dias até obter leituras constantes ou decrescentes;

10. montar uma tabela com as porcentagens de cimento e as leituras de cada dia:

- calcular a variação volumétrica percentual $(\% \Delta \mathrm{V})$ do sedimento solocimento em relação àquela do solo puro $(0 \%)$, para os diversos teores de cimento, escolhendo para o cálculo, o maior volume obtido para cada teor.

- fazer um gráfico de $\Delta \mathrm{V}(\%)$ versus $\% \mathrm{Ci}$. O ponto máximo de verificação volumétrica corresponde ao teor mínimo de cimento requerido para "satisfação" físico-química do solo.

A Figura 3.15 mostra as provetas com as respectivas porcentagens de cimento $(0,3,5,7,9$ e $11 \%)$ com $20,0 \mathrm{~g}$ de solo puro. O teor de cimento Portland utilizado nas misturas com solo-cimento foi relacionado com a massa de solo seco e nas misturas com solo-escória-cimento foi relacionado com a massa de solo e escória secos.

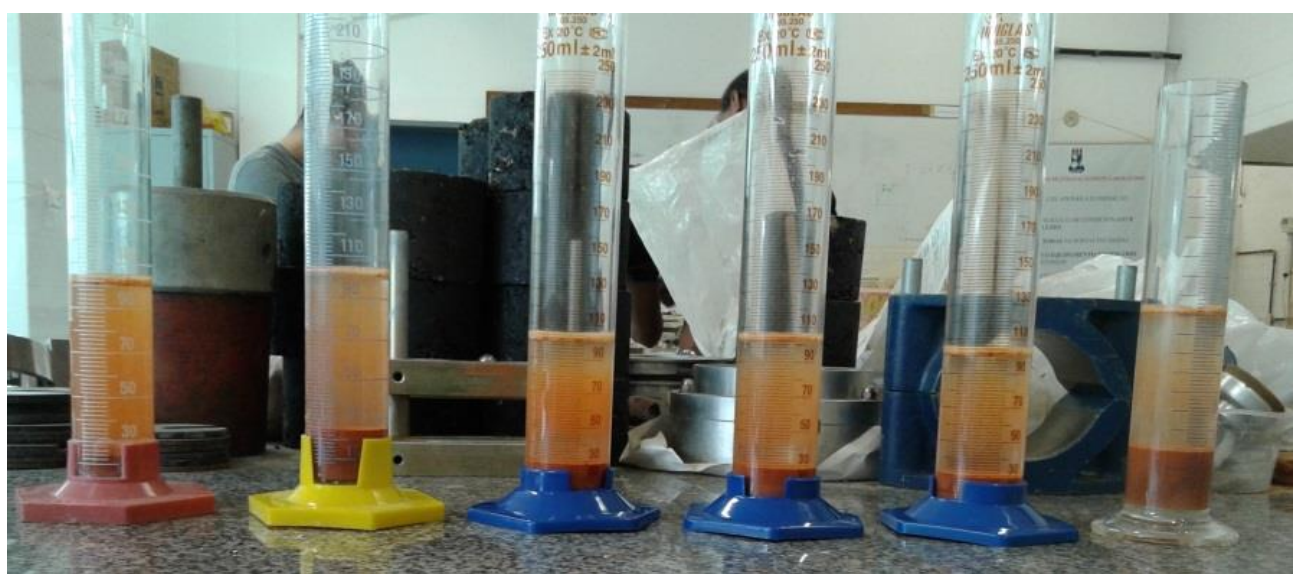

Figura 3.15 Dosagem físico-química do solo e cimento Portland. 


\subsubsection{0 \\ Caracterização mineralógica}

Para determinação mineralógica do solo e da escória foi realizado o ensaio de difração de raios $\mathrm{X}$ e para identificação quantitativa dos elementos presentes no solo, o ensaio de espectrometria de fluorescência de raios X.

(a) Difração de raios $X$

Para realização deste ensaio foram confeccionadas lâminas próprias para o difratômetro de raios X preparadas conforme o Manual de Métodos de Análise de Solo da Embrapa (1997). Uma massa de $50 \mathrm{~g}$ de solo passante na peneira 0,42mm (\#40) foi misturada ao hexametafosfato de sódio com concentração de 45,7 g do sal por $1000 \mathrm{~mL}$ de solução e deixada em repouso por um período de 12 horas. Após esse tempo, o material foi submetido à dispersão mecânica por 5 minutos e vertido na proveta de $1000 \mathrm{~mL}$, sendo completado o volume com água destilada.

Transcorrido um repouso de 24 horas, uma coluna líquida dos primeiros 20 $\mathrm{cm}$ da mistura foi retirada da proveta e armazenada em recipientes para evaporação do liquido restante. Gotejos da mistura foram pingados, com auxílio de uma pipeta, em lâminas e postas para secagem em temperatura ambiente, confeccionando-se assim as lâminas naturais, conforme ilustra a Figura 3.16.

Para preparação das lâminas com escória de cobre, o procedimento realizado foi passar uma determinada quantidade de escória pela peneira $0,075 \mathrm{~mm}$ e então pulverizá-la sobre a lâmina.

(a)

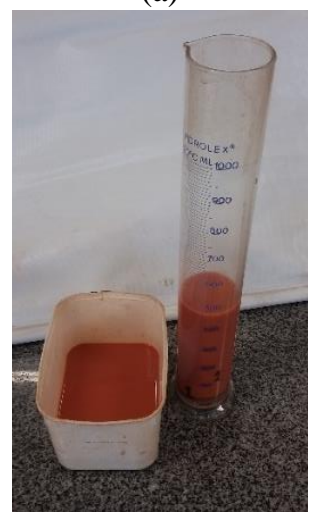

(b)

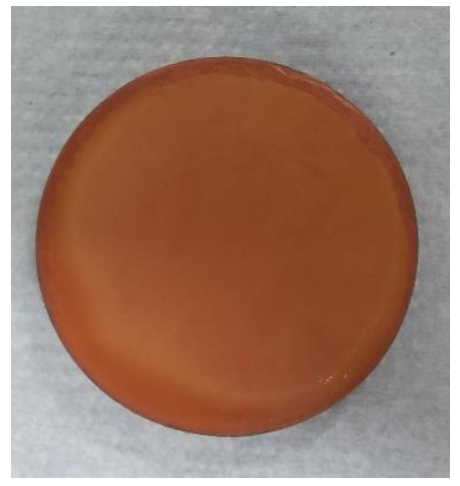

Figura 3.16 Preparação da amostra para ensaio de difração de raios X (a) e lâmina para ensaio (b). 
O ensaio no difratômetro foi realizado no Laboratório de Difratometria de Raios X pertencente ao Departamento de Física da UFS. O equipamento é o modelo D8 ADVANCE da empresa Bruker. As leituras do difratogramas foram realizadas em ângulos $2 \theta$ que variaram de 0 a $70^{\circ}$, numa velocidade de $0,02^{\circ} /$ segundo.

(b) Espectrometria de fluorescência de raios X

$\mathrm{O}$ ensaio de espectrometria fluorescência de raios $\mathrm{X}$ foi realizado a partir de amostras de solo passantes na peneira 0,42mm (\#40) que foram homogeneizadas e em seguida adicionadas em quantidades suficientes dentro de uma cubeta até cobrir todo o mylar (filme plástico). A cubeta deve ser lacrada com um anel para total vedação.

O ensaio no espectrofotômetro foi realizado no Laboratório de Ensaios Inorgânicos do Instituto Tecnológico e de Pesquisas do Estado de Sergipe (ITPS). $\mathrm{O}$ equipamento usado foi um espectrofotômetro de fluorescência de raios $\mathrm{X}$ de energia dispersiva, marca Schimadzu modelo EDX-720.

\subsubsection{1 \\ Microscopia eletrônica de varredura}

O ensaio de microscopia eletrônica de varredura (MEV) foi realizado no Laboratório FRX e MEV do Departamento de Geologia da UFS

As amostras foram submetidas ao recobrimento com uma finíssima camada de ouro, isto é, as amostras foram metalizadas no equipamento Kurt. J. Lesker Company 108 e em seguida foram ensaiadas no microscópio Tescan, modelo Veja 3, acoplado um detector de elétrons secundários, retroespalhado, cátodo de luminescência e EDS da Oxford Instruments modelo X-act.

\subsubsection{2}

\section{Lixiviação e solubilização}

A fim de classificar a escória de cobre pós-jateada quanto aos riscos potenciais ao meio ambiente e à saúde pública, isto é, classe I ou classe II, o material foi submetido aos procedimentos descritos nas seguintes normas ABNT:

NBR 10004/2004 - resíduos sólidos - classificação 
NBR 10005/2004 - procedimento para obtenção de extrato lixiviado de resíduos sólidos

$\checkmark$ NBR 10006/2004 - procedimento para obtenção de extrato solubilizado de resíduos sólidos

De acordo com a NBR 10005/2004, a lixiviação é um processo para determinação da capacidade de transferência de substâncias orgânicas e inorgânicas presentes no resíduo sólido, por meio de dissolução no meio extrator. O objetivo dessa norma é obter um extrato lixiviado de resíduos sólidos, visando diferenciar os resíduos classificados pela NBR 10004/2004 como classe I - perigosos - e classe II - não perigosos. A solução de extração foi obtida segundo o item 4.2 da referida norma e posto para agitação, como ilustrado na Figura 3.17. Após o período de 18 h, o extrato lixiviado foi encaminhado ao Laboratório de Química de Água do Instituto Tecnológico de Pesquisas do Estado de Sergipe (ITPS) e ao Laboratório de Estudos Ambientais da Universidade Tiradentes (UNIT) para as análises dos elementos presentes conforme o Anexo F da NBR 10004/2004.

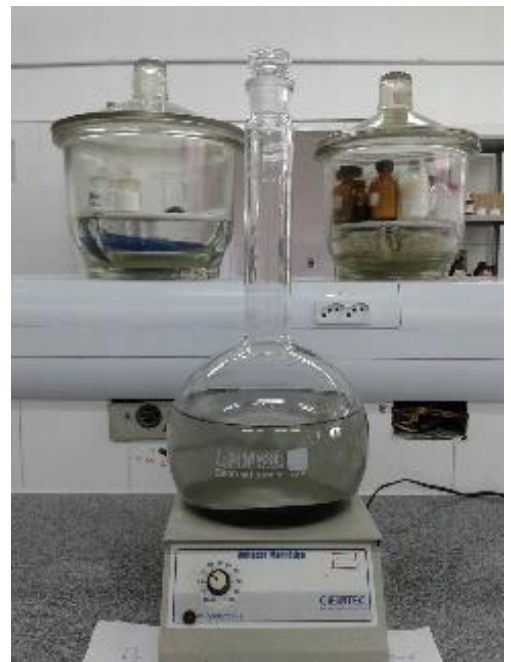

Figura 3.17 Procedimento para obtenção do extrato lixiviado da escória de cobre pós-jateada.

O procedimento para obtenção do extrato solubilizado, segundo a NBR 10006/2004 que tem o objetivo de obter esse extrato visando diferenciar os resíduos classificados na NBR 10004/2004 como classe II A - não inertes - e classe II B inertes. A Figura 3.18 apresenta parte a obtenção do extrato solubilizado. Após o repouso de 7 dias a solução foi filtrada e encaminhada aos Laboratórios do ITPS e de Estudos Ambientais para análises dos elementos presentes conforme o Anexo G da NBR 10004/2004. 

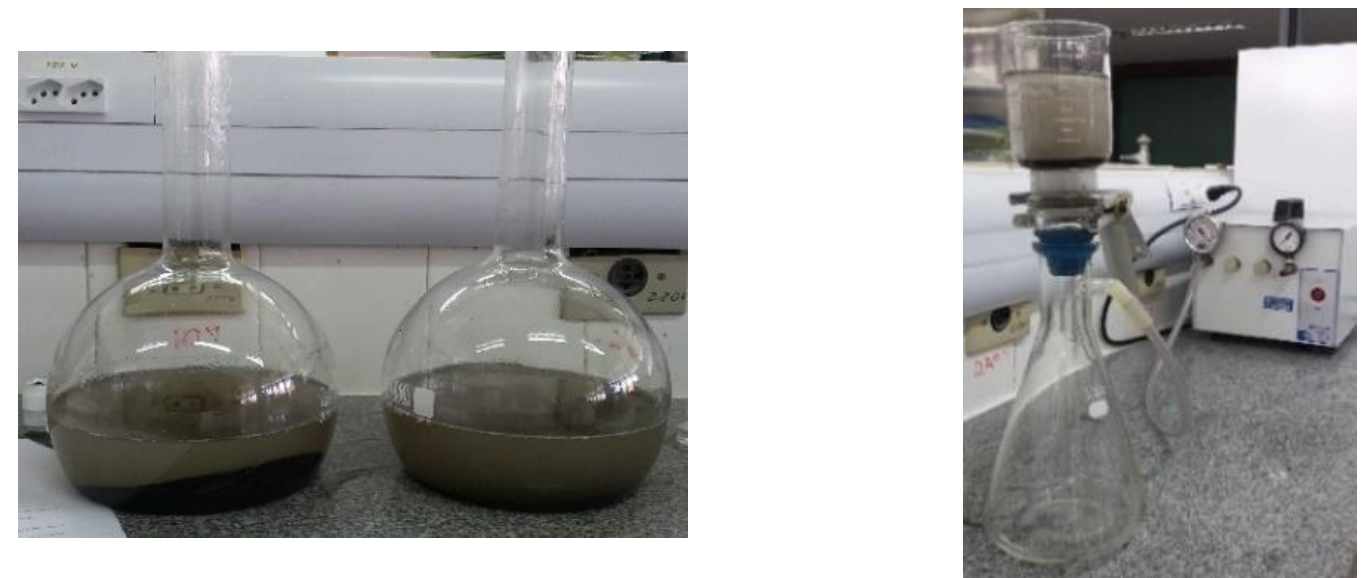

Figura 3.18 Procedimento para obtenção do extrato solubilizado da escória de cobre pós-jateada.

\section{5 \\ Dimensionamento do pavimento típico}

Visando uma análise mecanístico-empírica da viabilidade de aplicação do material estudado em bases de pavimentos utilizou-se o Programa Computacional SisPav versão v.2.0.8.2 (Franco, 2007), que emprega a Análise de Múltiplas Camadas, para obter tensões e deformações devido aos carregamentos. De acordo com Franco (2007), a abordagem da análise elástica não linear, feita pelo programa, é realizada de forma simplificada, com a divisão das camadas com este comportamento em três subcamadas.

Na Figura 3.19 é ilustrado o fluxograma básico no qual foi baseado o desenvolvimento do SisPav, com os detalhamentos para análise da influência do clima, da combinação dos diversos tipos de eixos e da variação lateral do tráfego.

Adotou-se uma estrutura de pavimento típico, no qual a espessura e as propriedades mecânicas do revestimento asfáltico e do subleito ficassem constantes, de maneira que as alterações fossem na espessura da base, de acordo com os parâmetros de resiliência para cada material. É importante ressaltar que os dados de clima utilizados na análise do programa, foram característicos para a cidade de Aracaju, já inseridos na base de dados do SisPav, e que, ainda para fins de cálculo, os dados de tráfego inseridos são correspondentes a rodovia de baixo volume de tráfego. 


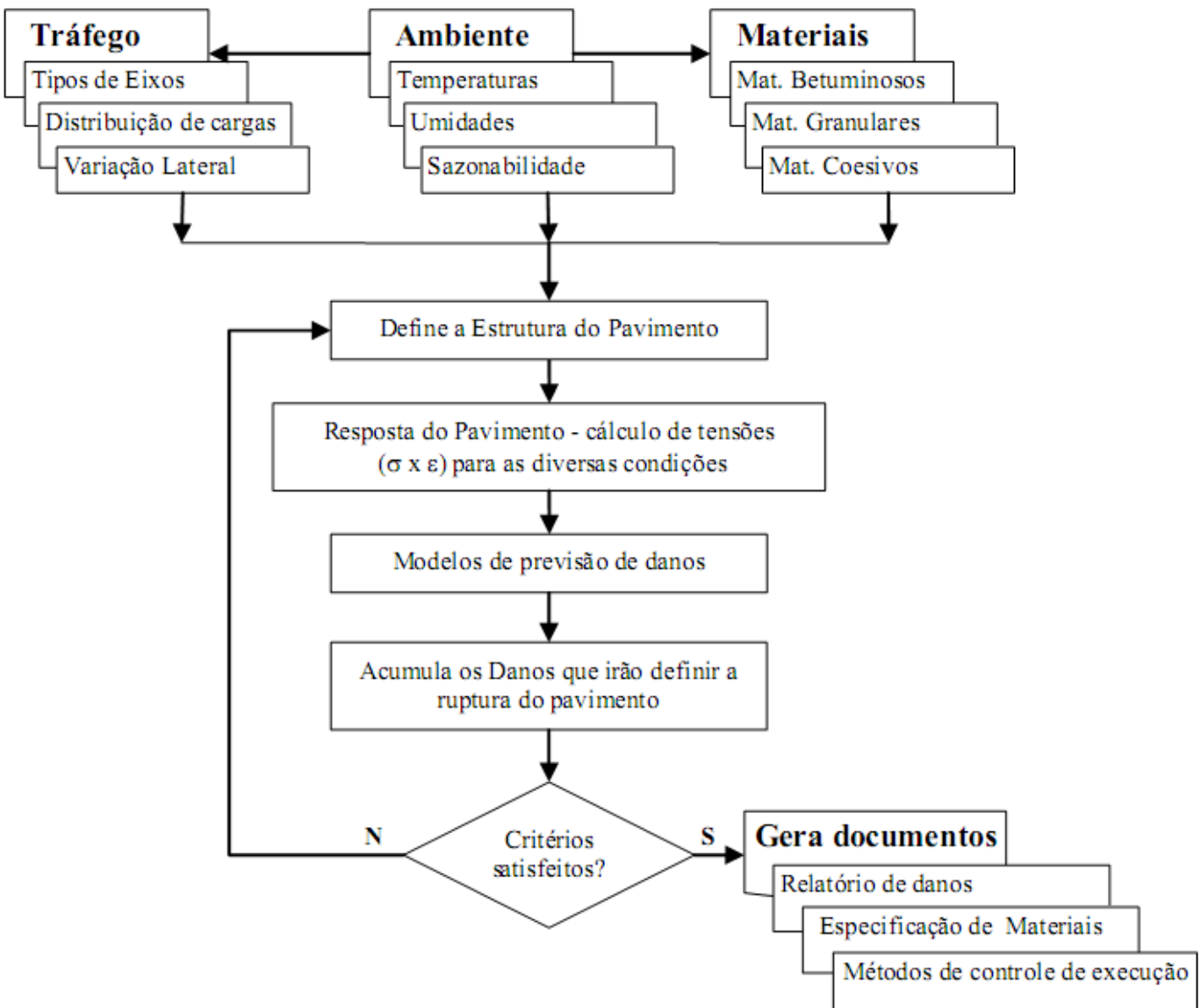

Figura 3.19 Fluxograma do SisPav (Franco, 2007).

\section{6}

\section{Considerações finais}

Neste capítulo foram apresentados os processos desde a coleta do solo, a escória e o cimento utilizados, além de descrever todo o programa experimental, incluindo a caracterização dos materiais empregados, os métodos de ensaios e equipamentos. Todo o programa foi desenvolvido com o intuito de alcançar o cumprimento que foi proposto nos objetivos desta pesquisa.

No capítulo a seguir são apresentados os resultados obtidos bem como a discussão destes. 


\section{Resultados e Análises}

\section{1}

\section{Caracterização do solo}

A Figura 4.1 mostra as curvas granulométricas dos ensaios realizados com as amostras de solo E.1 e E.2 da jazida Aningas utilizada nessa pesquisa, enquanto que a Tabela 4.1 apresenta as porcentagens de solo que passam nas respectivas peneiras para os dois ensaios. A granulometria média, segundo a AASHTO (1973), revelou que o solo está constituído das seguintes frações: $28,37 \%$ de pedregulho, 49,85\% de areia, $7,12 \%$ de silte e $14,66 \%$ de argila, o que permite caracterizá-lo como um solo areno-argiloso.

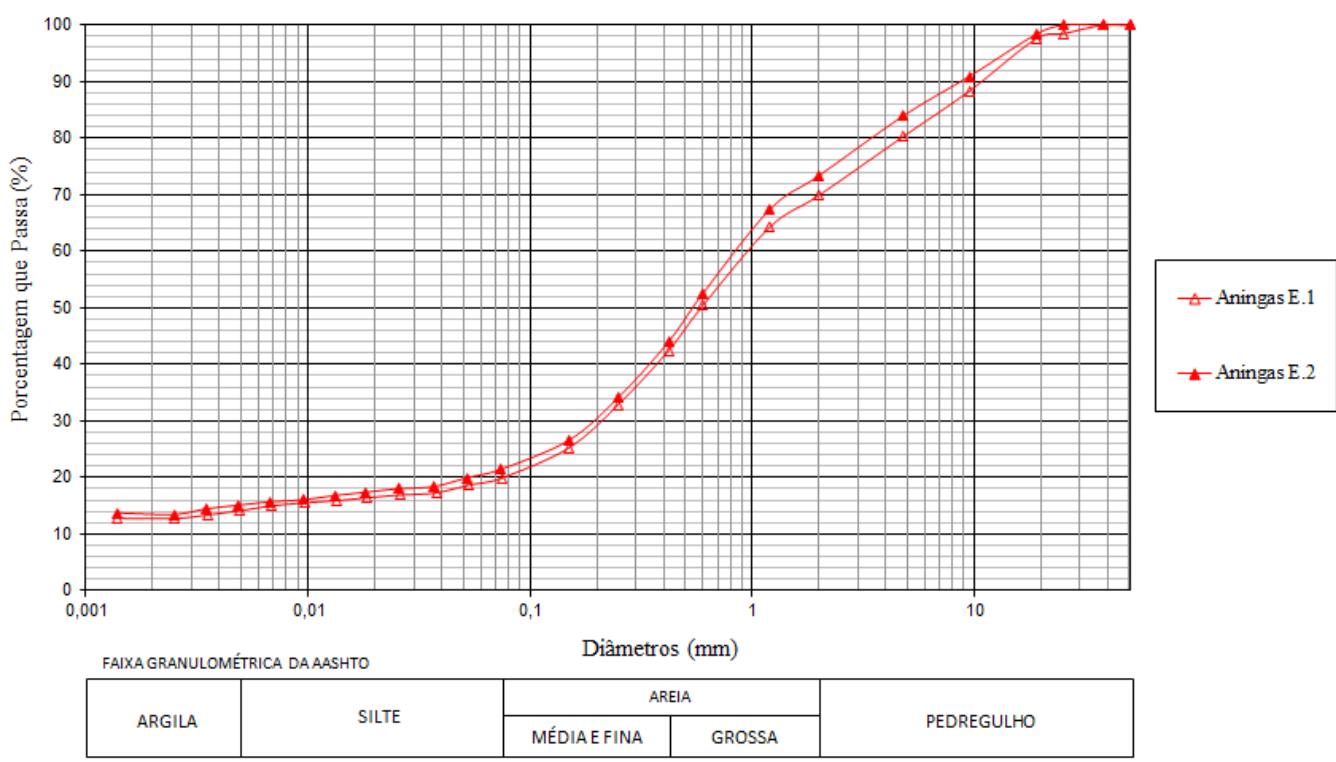

Figura 4.1 Curvas granulométricas das amostras de solo puro.

A densidade real dos grãos do solo foi de 2,69. Observa-se que esse parâmetro é uma característica associada à natureza mineralógica das partículas dos solos, pois depende dos minerais componentes e seus percentuais de ocorrência na amostra.

Os limites de Atterberg do solo estão apresentados na Tabela 4.2. O valor médio obtido para o IP, 16\%, revela um solo de plasticidade média, enquanto que o valor do índice de atividade da fração argila foi igual 1,1, que não é um valor tipicamente encontrado para os argilominerais expansivos. Porém, a fração fina 
desse solo reflete bem mais no comportamento plástico do solo. Segundo a relação apresentada por Mitchell (1976) e Das (2007), os argilominerais presentes nesse solo se aproximariam da caulinita e ilita, os quais poderão ser confirmados no ensaio de difração de raios $\mathrm{X}$.

Tabela 4.1 Resultados da análise granulométrica das amostras de solo puro.

\begin{tabular}{|c|c|c|c|c|}
\hline \multicolumn{2}{|c|}{ Peneira } & E. 1 & E. 2 & Média \\
\hline \multirow{13}{*}{ 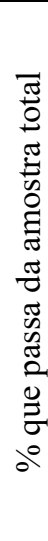 } & 2" & 100 & 100 & 100 \\
\hline & $11 / 2 "$ & 100 & 100 & 100 \\
\hline & $1 "$ & 98,49 & 100 & 99,25 \\
\hline & $3 / 4 "$ & 97,64 & 98,40 & 98,02 \\
\hline & $3 / 8 "$ & 88,31 & 90,91 & 89,61 \\
\hline & $n^{\circ} 4$ & 80,29 & 83,94 & 82,12 \\
\hline & $\mathrm{n}^{\circ} 10$ & 69,88 & 73,36 & 71,62 \\
\hline & $\mathrm{n}^{\circ} 16$ & 64,23 & 67,38 & 65,81 \\
\hline & $\mathrm{n}^{\circ} 30$ & 50,38 & 52,49 & 51,43 \\
\hline & $\mathrm{n}^{\circ} 40$ & 42.42 & 43,98 & 43,20 \\
\hline & $\mathrm{n}^{\circ} 60$ & 32,91 & 34,17 & 33,54 \\
\hline & $\mathrm{n}^{\circ} 100$ & 25,28 & 26,62 & 25,95 \\
\hline & $\mathrm{n}^{\circ} 200$ & 21,20 & 22,35 & 21,78 \\
\hline
\end{tabular}

Tabela 4.2 Limites de Atterberg das amostras de solo puro.

\begin{tabular}{l|c|c|c}
\hline Limites de Atterberg & E.1 & E.2 & Média \\
\hline Limite de Liquidez (\%) & 34 & 35 & 34 \\
Limite de Plasticidade (\%) & 18 & 18 & 18 \\
Índice de Plasticidade (\%) & 16 & 17 & 16 \\
\hline
\end{tabular}

A classificação do solo em estudo, segundo a metodologia dos sistemas AASHTO/TRB e USCS foi A-2-6 com índice de grupo 0 e SC, respectivamente.

As características dos solos do grupo A-2-6 são possuírem porcentagens entre 15 e $35 \%$ de material passando na peneira $n^{\circ} 200$, fração de finos contendo argila plástica e IG variando de 0 a 4. Para o grupo SC, os solos são caracterizados como arenosos com finos argilosos cuja plasticidade pode ser baixa ou alta, influenciando mais no comportamento do solo do que na composição granulométrica. De acordo com as inter-relações entre as classificações TRB e a Unificada, dentro da classe A-2-6, podem ser mais prováveis solos SC (DNIT, 2006).

Vale destacar uma informação sobre a classificação do solo Aningas após estudos de Santana (2014), empregando amostra dessa mesma jazida: os resultados obtidos classificaram como A-2-7(1), densidade real de 2,64, LL de 61\%, IP igual a $37 \%$ e CBR de $39 \%$. Isso mostra a variabilidade dos solos coletados numa mesma área de coleta da jazida. 
O ensaio de compactação do solo apresentou o valor de $21,07 \mathrm{kN} / \mathrm{m}^{3}$ para o peso específico aparente seco máximo e 8,9\% para o teor de umidade ótima. Os resultados obtidos são referentes ao Proctor intermediário e esses valores podem ser afetados tanto pelo tipo do solo, ou seja, distribuição granulométrica, forma dos grãos, densidade dos grãos, quantidade e tipo de argilominerais, quanto pelo efeito da energia de compactação. Como será visto mais adiante, tanto o peso específico quanto a umidade serão alterados com a adição gradativa da escória de cobre pósjateada, visto que houve uma modificação original do solo ao ser misturada a escória.

O índice de suporte califórnia obtido para o solo obtido foi de $46 \%$, com expansão igual a $0,1 \%$ como resultado médio dos dois ensaios executados, com as amostras moldadas sob energia de compactação do Proctor intermediário.

A Tabela 4.3 apresenta as características do solo, as quais auxiliaram na interpretação dos materiais à luz das normas relacionadas à estabilização de solo com cimento (DNIT 143/2010 - ES) e estabilizada granulometricamente (DNIT 141/2010 - ES e DNIT 139/2010 - ES). De acordo com a norma DNIT 143, o solo escolhido para esta pesquisa apresenta as características apropriadas para estabilização com cimento, tendo como finalidade a aplicação como material de base de pavimentos. No entanto, para uma estabilização granulométrica, segundo a norma DNIT 141, o solo se enquadra na Faixa D, mas não apresenta um $L L \leq 25 \%$, nem IP $\leq 6 \%$ e o ISC $\geq 80 \%$ com expansão $\leq 0,5 \%$ para energia Proctor modificada. Com relação à norma DNIT 139, o solo apresenta as características desejadas de IG $=0$ e ISC $\geq 20 \%$ com expansão $\leq 1 \%$.

O solo utilizado nesta pesquisa não seria indicado para estabilização granulométrica com a finalidade de uso com base de pavimentos, visto que apresenta limites superiores aos indicados na norma e quanto ao ISC não se pode garantir o valor mínimo de $80 \%$, com moldagem sob a energia do Proctor intermediária.

No entanto, para a estabilização granulométrica de sub-base, esse solo estaria enquadrado nas especificações da norma. Em relação à estabilização química com cimento Portland, a pergunta que se faz é: qual seria o teor mais adequado para estabilizar esse solo? A princípio, pode-se induzir, de acordo com a bibliografia, que esse solo não estaria descartado, mas provavelmente seria necessária uma 
porcentagem de aditivo para corrigir, principalmente, a plasticidade, conforme resultados das misturas que serão discutidos adiante.

Tabela 4.3 Dados de parte da granulometria, limites de Atterberg e ISC das amostras de solo puro.

\begin{tabular}{lc|c}
\hline \multicolumn{2}{c|}{ Peneiras } & \multirow{2}{*}{$\begin{array}{c}\text { Média do material } \\
\text { passante }(\%)\end{array}$} \\
\cline { 1 - 2 } \multicolumn{1}{c|}{ pol } & $\mathrm{mm}$ & 100 \\
1 & 50,8 & 99,25 \\
$3 / 8$ & 25,4 & 89,61 \\
$\mathrm{~N}^{\circ} 4$ & 9,5 & 82,12 \\
$\mathrm{~N}^{\circ} 10$ & 4,8 & 71,62 \\
$\mathrm{~N}^{\circ} 40$ & 2,0 & 43,20 \\
$\mathrm{~N}^{\circ} 200$ & 0,42 & 21,78 \\
\cline { 1 - 2 } \multicolumn{2}{c}{ Limite de liquidez } & $34 \%$ \\
Índice de plasticidade & $16 \%$ \\
\hline \multicolumn{2}{c|}{ ISC } & $46 \%$ \\
\multicolumn{2}{c|}{ Expansão } & $0,1 \%$ \\
\hline
\end{tabular}

Os resultados do ensaio de resistência à compressão simples e da umidade de moldagem dos corpos de prova do solo estão apresentados na Tabela 4.4. Vale observar que o ensaio com o solo puro foi realizado para servir de parâmetro de comparação, pois não existe normatização para a resistência de solo puro.

Tabela 4.4 Resistência à compressão simples e da umidade de moldagem dos corpos de prova do solo puro.

\begin{tabular}{l|cccc}
\hline \multicolumn{1}{c|}{ Parâmetro } & E.1 & E.2 & E.3 & Média \\
\hline Resistência à compressão simples $(\mathrm{MPa})$ & 0,70 & 0,90 & 0,90 & 0,83 \\
Umidade de moldagem $(\%)$ & 9,0 & 8,2 & 8,6 & 8,6 \\
\hline
\end{tabular}

A partir desses resultados, pode-se observar uma diferença considerável entre os valores obtidos para a RCS entre ensaio E.1 e os outros dois de cerca de 30\%, que pode ser atribuída as várias frações do solo, mesmo os dois ensaios apresentando os mesmos resultados, mas isso ocorreu ao acaso. No momento da moldagem, uma quantidade maior de pedregulho pode ter acumulado em uma região do corpo de prova implicando essa diferença de resistência.

Outra observação é com relação à umidade de moldagem, que quando comparada à umidade ótima $(8,9 \%)$, o valor da moldagem foi levemente menor. 
Isso ocorreu devido às dificuldades encontradas no momento da moldagem, na operação de se adicionar a água necessária para se atingir o teor de umidade ótimo, mesmo tomando-se todos os cuidados nos cálculos para essa adição. A mesma dificuldade ocorreu para as misturas com escória e cimento, conforme será visto mais adiante. Essa diferença de umidades de moldagem entre os ensaios pode ser atribuída as frações mais finas do solo que absorvem água, visto que a fração mais grossa (até \# n॰10) não têm essa tendência de absorver.

Na Tabela 4.5 estão apresentados os resultados das constantes de regressão dos modelos para os ensaios triaxiais de carga repetida. Esses modelos matemáticos para a obtenção dos valores do MR em função das tensões e deformações aplicadas aos corpos de prova foram descritos por vários autores (e.g. Macêdo, 1996; Ferreira, 2002; Bernucci et al. 2006; Viana, 2007).

Tabela 4.5 Parâmetros de resistência e coeficiente de determinação obtidos a partir dos modelos para os ensaios de MR das amostras de solo puro.

\begin{tabular}{l|cccc}
\hline \multicolumn{1}{c|}{ Modelo } & \multicolumn{5}{c}{ Parâmetros } \\
& $\mathrm{K}_{1}$ & $\mathrm{~K}_{2}$ & $\mathrm{~K}_{3}$ & $\mathrm{R}^{2}$ \\
\hline $\mathrm{MR}=\mathrm{k}_{1 .} \sigma_{3}{ }^{\mathrm{k}}{ }$ & 3768,7 & 0,5625 & - & 0,7511 \\
$\mathrm{MR}=\mathrm{k}_{1} . \sigma^{\mathrm{k}}{ }_{2}$ & 2235,9 & 0,4807 & - & 0,8248 \\
$\mathrm{MR}=\mathrm{k}_{1} . \sigma_{3}{ }^{\mathrm{k}}{ }_{2} \cdot \sigma_{\mathrm{d} 3} \mathrm{k}_{3}$ & 4160 & 0,5383 & 0,0831 & 0,8717 \\
\hline
\end{tabular}

A equação dependente da tensão confinante descreve o comportamento de solos arenosos, sem coesão e a equação dependente da tensão desvio é mais indicada para solos coesivos (Ferreira, 2002). Porém, o modelo composto dependente da tensão confinante e desvio é indicado para qualquer tipo de material (Macêdo, 1996). Analisando os coeficientes, verifica-se que o modelo composto se aplicou melhor ao comportamento do solo puro, condizendo com estudos realizados por Macêdo (1996). Observa-se pelos outros dois modelos uma dependência das tensões, principalmente da tensão desvio $\left(\sigma_{\mathrm{d}}\right)$. Na Figura 4.2 é mostrada a superfície no espaço tridimensional $\left(\sigma_{3}, \sigma_{\mathrm{d}} \mathrm{x} \mathrm{MR}\right)$ para as tensões aplicadas que foram geradas por ajustes, baseadas no modelo composto. 


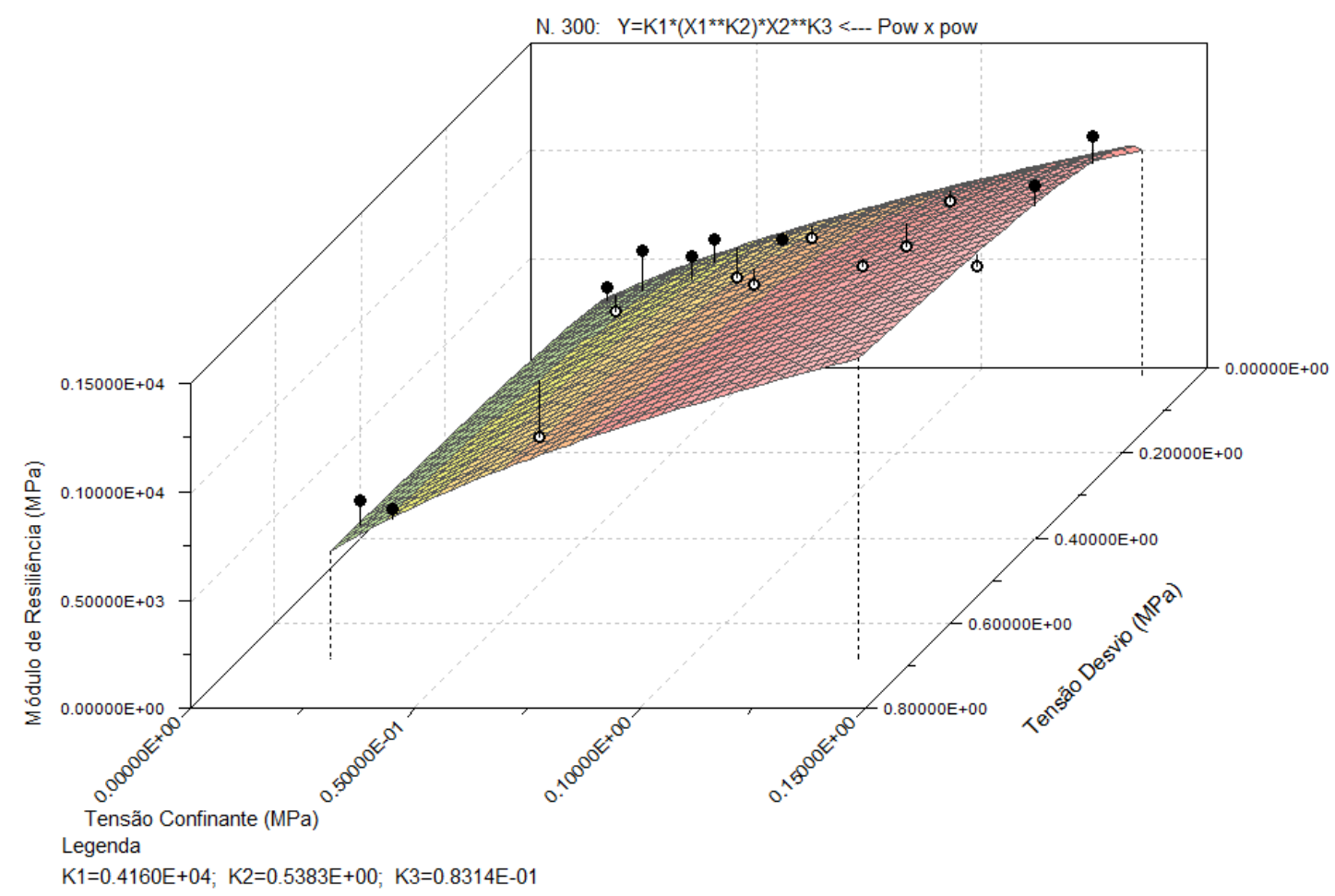

Figura 4.2 Gráfico 3D do modelo composto do módulo de resiliência do solo puro.

A análise química do solo por meio da fluorescência de raios $\mathrm{X}$ foi realizada para determinação dos componentes químicos e os resultados estão apresentados na Tabela 4.6. Os resultados evidenciam que as argilas são compostas por silicatos hidratados de alumínio e ferro, dada suas altas porcentagens, contendo ainda certo teor de elementos alcalinos e alcalinos terrosos (Santos, 1979). De acordo com Costa (2004), a cor avermelhada do solo pode ser atribuída ao óxido de ferro presente, o que se confirma para o solo estudado. Ainda segundo o autor, a presença de ferro combinado em teores acima de $2 \%$ indica a existência do argilomineral do grupo 2:1.

Com base na análise dos resultados dos ensaios de difração de raios $\mathrm{X}$ do solo, apresentado na Figura 4.3, foi possível identificar os argilominerais: caulinita e ilita. A detecção desses argilominerais contribui muito para otimizar o processo de estabilização química do solo, conforme apontado por Croft (1967), uma vez que solos cauliníticos e ilíticos são inertes e desenvolvem resistências satisfatórias com quantidades econômicas de cimento, não inibindo a hidratação e o endurecimento do aditivo. 
Tabela 4.6 Constituição química das amostras do solo puro.

\begin{tabular}{l|c|c||c|c|c}
\hline Elemento & Resultado & Unidade & Elemento & Resultado & Unidade \\
\hline Silício & 14,64 & $\%$ & Sódio & 00,7 & $\%$ \\
Ferro & 10,94 & $\%$ & Enxofre & 0,002 & $\%$ \\
Alumínio & 10,43 & $\%$ & Cromo & 170,59 & $\mathrm{ppm}$ \\
Titânio & 0,60 & $\%$ & Manganês & 104,83 & $\mathrm{ppm}$ \\
Potássio & 0,37 & $\%$ & Chumbo & 86,46 & $\mathrm{ppm}$ \\
Cálcio & 0,30 & $\%$ & Cobalto & 32,33 & $\mathrm{ppm}$ \\
Magnésio & 0,08 & $\%$ & Estrôncio & 21,02 & $\mathrm{ppm}$ \\
Fósforo & 0,07 & $\%$ & Zinco & 10,61 & $\mathrm{ppm}$ \\
\hline
\end{tabular}

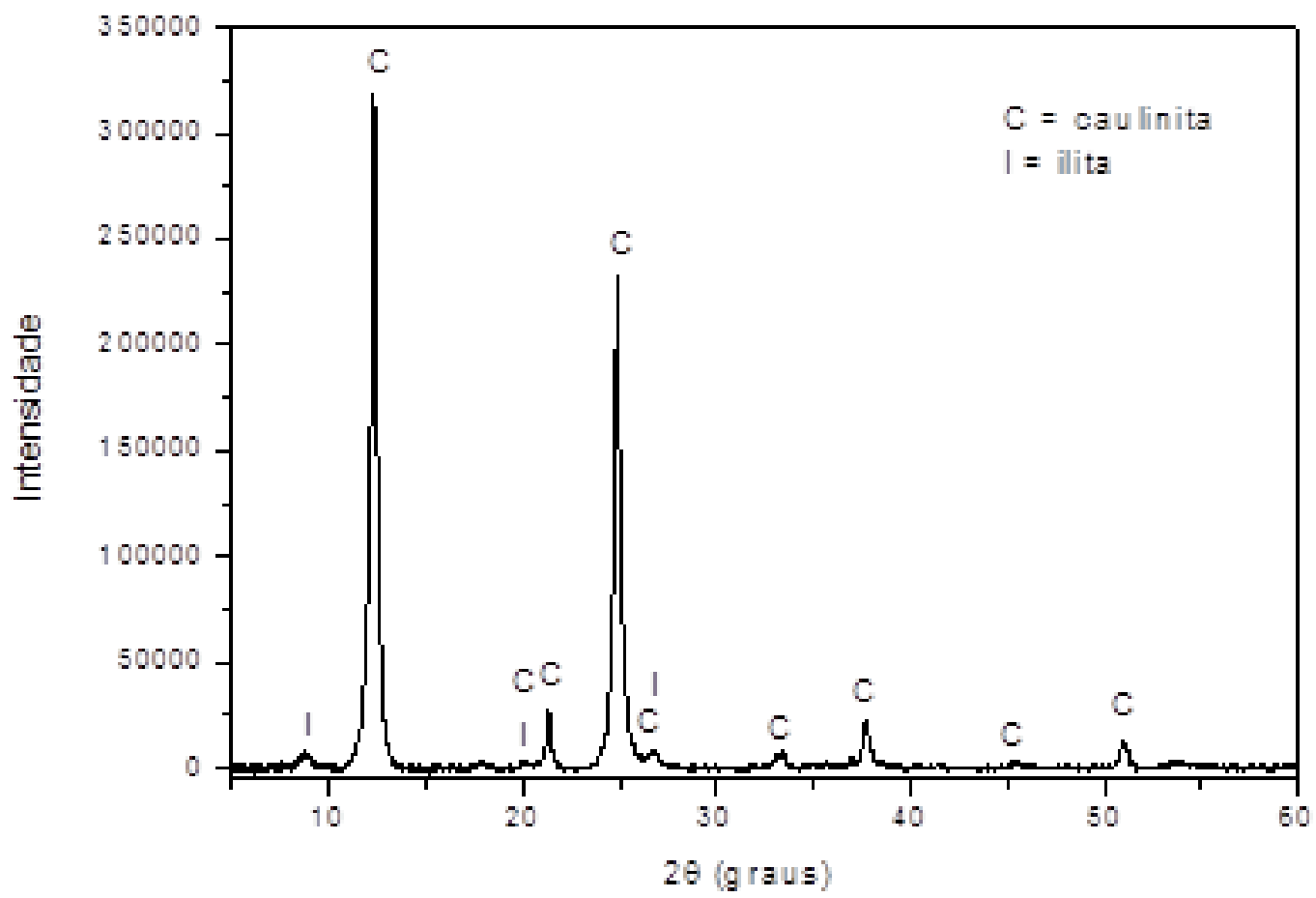

Figura 4.3 Difratograma de raios $\mathrm{X}$ das amostras de solo puro.

Os ensaios de permeabilidade do solo acusaram um valor de $1,4 \times 10^{-4} \mathrm{~cm} / \mathrm{s}$, indicando um resultado variando entre as areias e silte, cuja ordem de grandeza pode varia de $10^{0}$ a $10^{-5} \mathrm{~cm} / \mathrm{s}$ (e.g. Vargas, 1977; Pinto, 2006; Das, 2007, Fernandes, 2011) e um grau de permeabilidade de médio a baixo. Os fatores que podem influenciar a permeabilidade no meio poroso são: tamanho e arranjo dos grãos, índice de vazios, composição química, densidade e viscosidade da água. 
Quanto ao tamanho e o arranjo dos grãos tem influência dado o diâmetro das partículas como também a forma dos canalículos de fluxo e sua tortuosidade. Já o índice de vazios tem influência na permeabilidade por duas razões: um aumento na porcentagem da área da seção transversal disponível para o fluxo e um acréscimo na dimensão dos poros, que aumenta a velocidade média do fluxo no poro. Solos com o mesmo índice de vazios, mas diferentes estruturas, a maior permeabilidade ocorre na argila de estrutura floculada devido à existência de poros maiores, que oferecem menor resistência à passagem da água do que na estrutura dispersa.

Para a composição química, a influência maior é para as argilas, em que, dependendo do argilomineral presente em sua microestrutura, a permeabilidade pode ser muito baixa. No caso do solo estudado nesta pesquisa, não foi detectada a presença de argilominerais expansivos, sendo pouco a influência da composição no resultado da permeabilidade. Para o fator densidade e viscosidade da água, quanto mais viscosa maior será a dificuldade de atravessar os poros e como essa propriedade é influenciada pela temperatura, a permeabilidade também o será. Como o ensaio foi realizado em laboratório sem variações de temperatura, esse último fator tem pouca influência no resultado do coeficiente de permeabilidade.

\section{2 \\ Caracterização físico-química da escória}

A Figura 4.4 mostra as curvas granulométricas dos ensaios realizados com as amostras E.1 e E.2 da escória de cobre pós-jateada utilizada nessa pesquisa, enquanto a Tabela 4.7 apresenta as porcentagens da escória que passam nas respectivas peneiras para os dois ensaios. A granulometria média, segundo a AASHTO (1973), revelou que a escória está constituída das seguintes frações: $0,06 \%$ de pedregulho; $92,32 \%$ de areia; $7,13 \%$ de silte e $0,49 \%$ de argila, o que permite caracterizá-la como uma areia.

A densidade real da escória utilizada foi 3,73. Esse valor elevado deve-se provavelmente à quantidade de óxido de ferro presente na escória, além daquela quantidade que desprende da superfície metálica durante o processo de jateamento. Para a escória pós-jateada usada no trabalho de Anjos (2015) foi obtido um valor de densidade ainda superior ao obtido nesta pesquisa, ou seja, 3,85. 


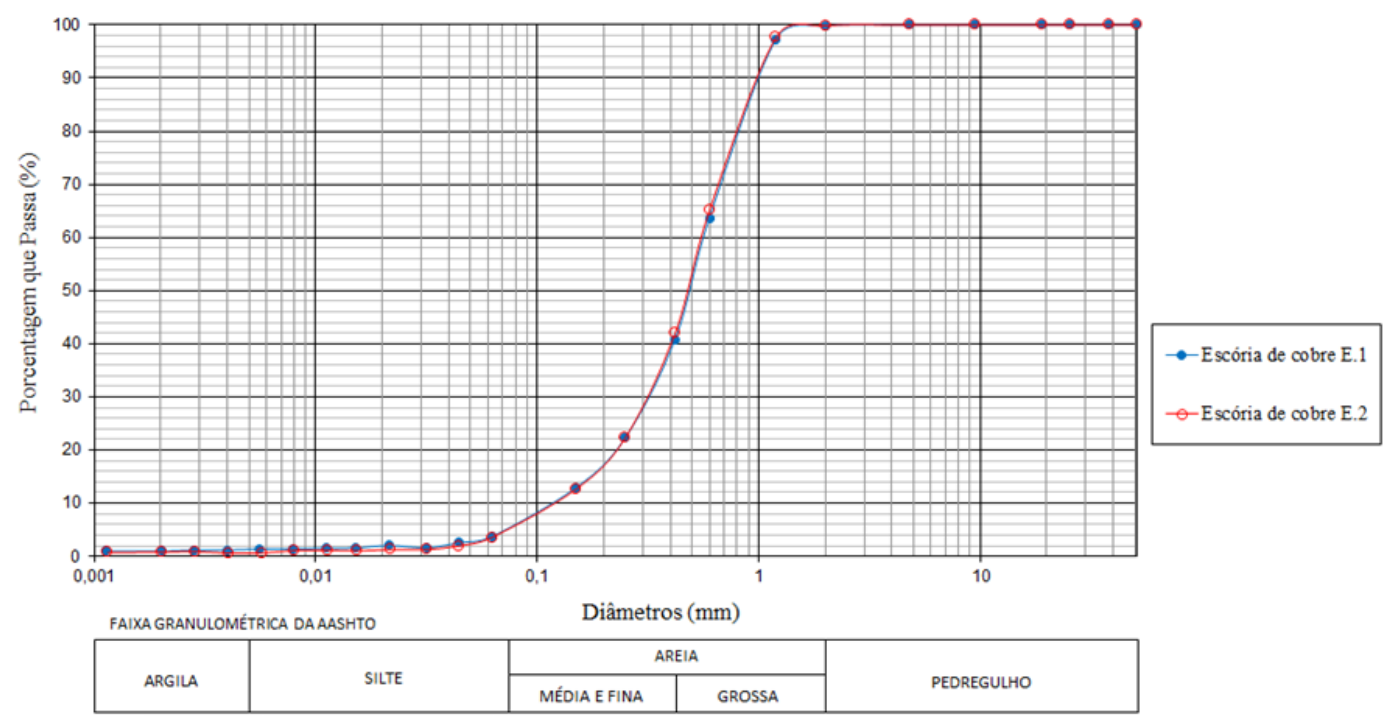

Figura 4.4 Curvas granulométricas das amostras de escória de cobre pós-jateada.

Tabela 4.7 Resultados da análise granulométrica das amostras de escória de cobre pós-jateada.

\begin{tabular}{|c|c|c|c|c|}
\hline \multicolumn{2}{|c|}{ Peneira } & E. 1 & E. 2 & Média \\
\hline \multirow{13}{*}{ 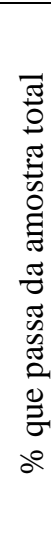 } & $2 "$ & 100 & 100 & 100 \\
\hline & $11 / 2 "$ & 100 & 100 & 100 \\
\hline & $1 "$ & 100 & 100 & 100 \\
\hline & $3 / 4 "$ & 100 & 100 & 100 \\
\hline & $3 / 8 "$ & 100 & 100 & 100 \\
\hline & $n^{\circ} 4$ & 100 & 100 & 100 \\
\hline & $\mathrm{n}^{\circ} 10$ & 99,93 & 99,95 & 99,94 \\
\hline & $\mathrm{n}^{\circ} 16$ & 99,40 & 99,50 & 99,45 \\
\hline & $\mathrm{n}^{\circ} 30$ & 82,34 & 85,76 & 84,05 \\
\hline & $\mathrm{n}^{\circ} 40$ & 62,66 & 66,47 & 64,57 \\
\hline & $\mathrm{n}^{\circ} 60$ & 41,45 & 44,49 & 42,97 \\
\hline & $\mathrm{n}^{\circ} 100$ & 19,86 & 21,36 & 20,61 \\
\hline & $\mathrm{n}^{\circ} 200$ & 8,02 & 7,21 & 7,62 \\
\hline
\end{tabular}

Os limites de Atterberg não foram possíveis de obter devido a própria característica da escória, com cerca de $93 \%$ na fração areia, sendo um material nãoplástico. De acordo com a ASTM D-3282-09, se o solo é não-plástico e quando o limite de liquidez não pode ser determinado, refere-se o índice de grupo como zero (0). Levando-se em consideração essa informação da referida norma, adotou-se, portanto, o IG para a escória de cobre pós-jateada como sendo zero (0) por não ter sido possível determinar o limite de liquidez.

A classificação da escória em estudo, segundo a metodologia dos sistemas AASHTO/TRB e USCS foi A-3 com índice de grupo 0 e SP, respectivamente. Quanto a essa classificação, o material típico do grupo das areias finas de praia ou de deserto, sem silte ou argila, ou possuindo pequena quantidade de silte não plástico, que é o presente caso. Para o grupo SP, os materiais podem ser classificados como cascalhos uniformes (também chamados de macadames), areias 
uniformes, ou misturas não-uniformes de material muito grosso, e areia muito fina, faltando partículas com tamanhos intermediárias (DNIT, 2006). De fato, a escória de cobre pós-jateada, utilizada nesta pesquisa, tem um aspecto de areia média a fina e ao contato tátil sente-se a aspereza dada pela sua granulometria.

A granulometria revela que a escória se apresenta praticamente como uma areia $(92,32 \%)$, sendo o total dessa fração, em média, 0,06\% corresponde a granulometria de areia grossa e 92,26\% granulometria de areia média e fina. A essa grande quantidade de material na fração areia média e fina, além da pouca porcentagem de material passante na \#200 (7,62\%), contribuem para a não plasticidade da escória.

Seguindo os procedimentos das normas de classificação dos resíduos e os procedimentos para obtenção do extrato lixiviado e solubilizado, a escória de cobre pós-jateada apresentou os resultados mostrados nas Tabelas 4.8 e 4.9, respectivamente. De acordo com as características de toxicidade, apesar de o resíduo apresentar componentes do Anexo F da norma NBR 10004, os resultados encontram-se abaixo dos limites máximos descritos nesse Anexo. Dessa forma, classifica a escória de cobre pós-jateada como resíduo classe II - não perigoso.

Ainda de acordo com a classificação da referida norma, o resíduo pode ser classe II -A ou classe II - B. Como os resultados apresentaram teores de mercúrio e fenóis totais acima dos limites descritos no Anexo G da norma 10004, a escória utilizada nessa pesquisa enquadra-se na classe de resíduos classe II - A - não perigoso - não inerte.

A escória de cobre original, isto é, antes de passar pelo processo de jateamento foi submetida à análise de fluorescência de raios X para determinação da sua composição química e os resultados estão apresentados na Tabela 4.10. Observa-se que as maiores quantidades são óxido de ferro e de silício. Esses resultados são comparados a outros citados na literatura, com maiores variações para as composições de ferro e silício (Shi et al., 2008; Zain et. al., 2004; Gorai et al., 2003; Moura, 2000). 
Tabela 4.8 Resultados do ensaio de lixiviação das amostras de escória de cobre pós-jateada comparação com a listagem apresentada no anexo F da NBR 10004/2004.

\begin{tabular}{l|c|c|c}
\hline Parâmetro & $\begin{array}{c}\text { Limite de quantificação } \\
(\mathrm{mg} / \mathrm{L})\end{array}$ & $\begin{array}{c}\text { Resultado } \\
(\mathrm{mg} / \mathrm{L})\end{array}$ & $\begin{array}{c}\text { Limite máximo no lixiviado } \\
(\mathrm{mg} / \mathrm{L})-\text { Anexo F }\end{array}$ \\
\hline Arsênio & 0,011 & $<0,011$ & 1,0 \\
Cádmio total & 0,005 & $<0,005$ & 0,5 \\
Chumbo total & 0,010 & 0,40 & 1,0 \\
Cromo total & 0,028 & $<0,028$ & 5,0 \\
Fluoretos total & 0,050 & 0,01 & 150 \\
Mercúrio & 0,001 & $<0,001$ & 0,1 \\
Prata total & 0,030 & $<0,030$ & 5,0 \\
Selênio & 0,005 & $<0,005$ & 1,0 \\
Fenóis totais & 0,002 & $<0,002$ & - \\
Cloretos & 2,42 & 3,16 & - \\
\hline
\end{tabular}

Tabela 4.9 Resultados do ensaio de solubilização das amostras de escória de cobre pós-jateada comparação com a listagem apresentada no anexo G da NBR 10004/2004.

\begin{tabular}{l|c|c|c}
\hline Parâmetro & $\begin{array}{c}\text { Limite de quantificação } \\
(\mathrm{mg} / \mathrm{L})\end{array}$ & $\begin{array}{c}\text { Resultado } \\
(\mathrm{mg} / \mathrm{L})\end{array}$ & $\begin{array}{c}\text { Limite máximo no extrato } \\
(\mathrm{mg} / \mathrm{L})-\text { Anexo G }\end{array}$ \\
\hline Arsênio & 0,011 & $<0,011$ & 0,01 \\
Cádmio total & 0,005 & $<0,0014$ & 0,005 \\
Chumbo total & 0,010 & $<0,007$ & 0,01 \\
Cromo total & 0,028 & $<0,028$ & 0,05 \\
Fluoreto total & 0,050 & 0,09 & 1,5 \\
Mercúrio & 0,001 & 0,002 & 0,001 \\
Prata total & 0,030 & $<0,0072$ & 0,05 \\
Selênio total & - & $\mathrm{ND}$ & 0,01 \\
Fenóis totais & 0,002 & 0,040 & 0,01 \\
Cloretos & 0,050 & 2,11 & 250 \\
\hline
\end{tabular}

Tabela 4.10 Composição química das amostras de escória de cobre original.

\begin{tabular}{l|c}
\multicolumn{1}{c}{ Componente } & Porcentagem (\%) \\
\hline $\mathrm{Fe}_{2} \mathrm{O}_{3}$ (óxido de ferro) & 20,84 \\
$\mathrm{SiO}_{2}$ (óxido de silício) & 60,32 \\
$\mathrm{ZnO}$ (óxido de zinco) & 1,51 \\
$\mathrm{CuO}$ (óxido de cobre) & 4,65 \\
$\mathrm{Al}_{2} \mathrm{O}_{3}$ (óxido de alumínio) & 5,78 \\
$\mathrm{CaO}$ (óxido de cálcio) & 4,83 \\
$\mathrm{MgO}$ (óxido de magnésio) & 2,07 \\
\hline
\end{tabular}

A composição química da escória de cobre pós-jateada está apresentada na Tabela 4.11. Observa-se uma mudança na composição química: aumento de $281 \%$ no teor de óxido de ferro; redução de $81 \%$ no óxido de silício e a detecção de outros componentes, indicando que no processo abrasivo sobre a superfície metálica partículas de ferro são arrancadas dessa superfície, além dos componentes 
provenientes da pintura. Esse aumento no teor de ferro favorece a elevada densidade da escória como descrito anteriormente.

Tabela 4.11 Composição química das amostras de escória de cobre pós-jateada.

\begin{tabular}{l|c}
\multicolumn{1}{c}{ Componente } & Porcentagem (\%) \\
\hline $\mathrm{Fe}_{2} \mathrm{O}_{3}$ (óxido de ferro) & 79,50 \\
$\mathrm{SiO}_{2}$ (óxido de silício) & 11,20 \\
$\mathrm{ZnO}$ (óxido de zinco) & 2,06 \\
$\mathrm{CuO}$ (óxido de cobre) & 2,00 \\
$\mathrm{MoO}_{3}$ (óxido de molibdênio) & 1,23 \\
$\mathrm{Al}_{2} \mathrm{O}_{3}$ (óxido de alumínio) & 1,08 \\
$\mathrm{CaO}$ (óxido de cálcio) & 0,67 \\
$\mathrm{SO}_{3}$ (trióxido de enxofre) & 0,67 \\
$\mathrm{PbO}$ (óxido de chumbo) & 0,46 \\
$\mathrm{MgO}^{\prime}$ (óxido de magnésio) & 0,41 \\
$\mathrm{~K}_{2} \mathrm{O}$ (óxido de potássio) & 0,31 \\
$\mathrm{TiO}_{2}$ (óxido de titânio) & 0,31 \\
$\mathrm{Cr}_{2} \mathrm{O}_{3}$ (óxido de cromo III) & 0,10 \\
\hline
\end{tabular}

Nos resultados de Anjos (2015), utilizando a mesma escória dessa pesquisa, foi detectado que o resíduo não apresenta atividade pozolânica para uma substituição de $40 \%$ em massa de escória, isto é, a escória não poderia substituir o aglomerante em misturas cimentícias. Bharati e Chen (2016) trabalhando com misturas de argila mole, cimento e escória detectaram, através de difração de raios $\mathrm{X}$, que o teor de $30 \%$ de escória contribuiu para a atividade pozolânica da mistura.

Imagens obtidas da microscopia eletrônica de varredura (MEV) para a escória de cobre após o processo de jateamento estão mostradas na Figura 4.5. A partir delas é possível observar a morfologia irregular dos grãos em sua maioria angulosos, com lados afiados (Figura 4.5a) e ainda alguns arredondados (Figura 4.5b). Essas mesmas características da escória foram reportadas na literatura (e.g. Prasad e Ramana, 2016; Shi et al., 2008; Zain et al. 2004; Gorai et al., 2003). A princípio essa forma irregular pode ser favorável ao aumento da resistência, pois poderá existir um entrosamento entre as partículas do solo e da escória.

Nota-se da Figura 4.5 uma superfície lisa e isenta de poros, como também observado por Moura (2000). Nos ensaios realizados por Anjos (2015) com a 
mesma escória utilizada nesta pesquisa foi obtida uma absorção de $0,33 \%$, o que confirma a baixa absorção dos grãos pela falta de poros.

(a)

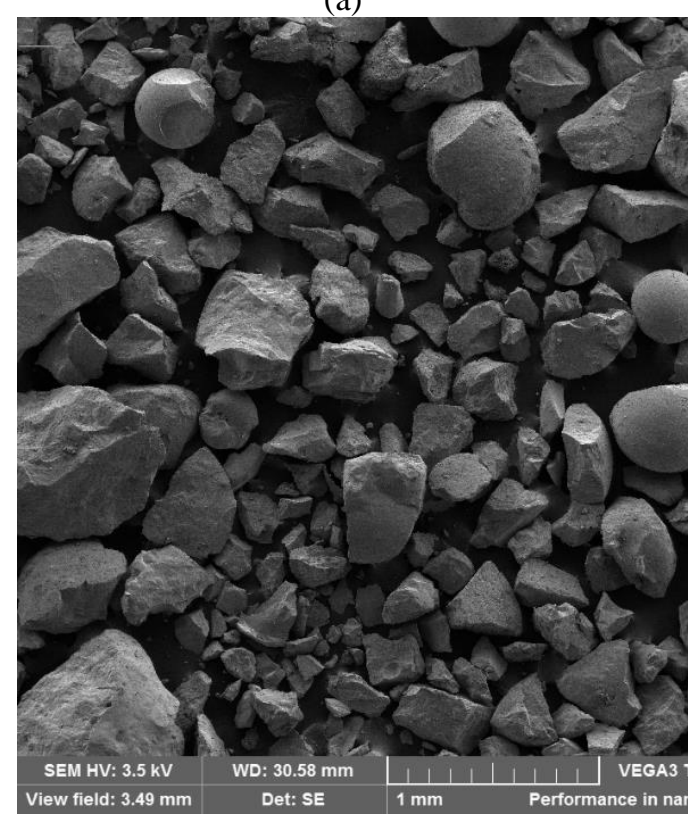

(b)

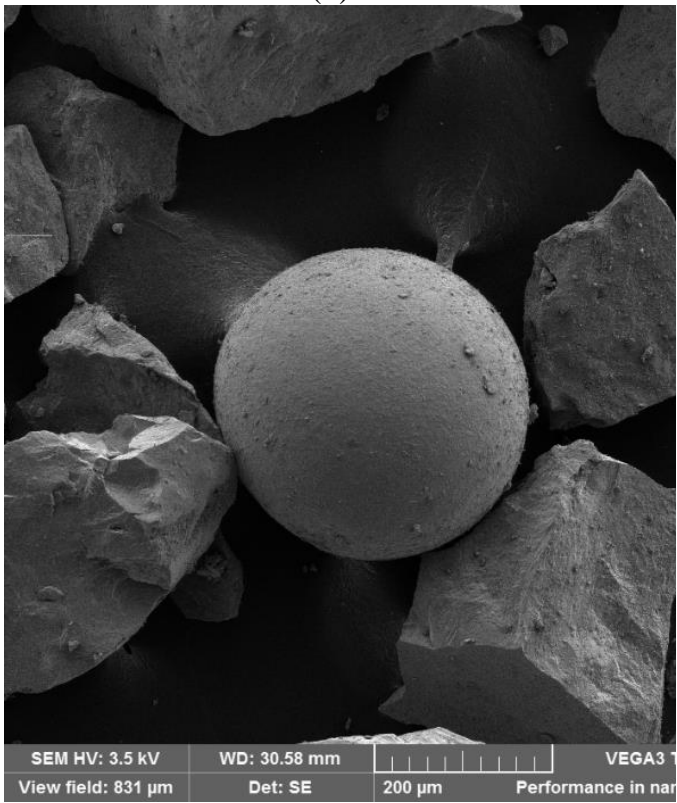

Figura 4.5 Microscopia eletrônica de varredura das amostras de escória de cobre pós-jateada.

O resultado da difração de raios X para a escória de cobre utilizada nessa pesquisa está apresentado na Figura 4.6. Da análise desse difratograma, observa-se a mesma conformação típica apresentada por Resende (2009), Gorai et al., (2003) e Moura (2000), indicando uma fração cristalina dos minerais faialita, magnetita e hematita.

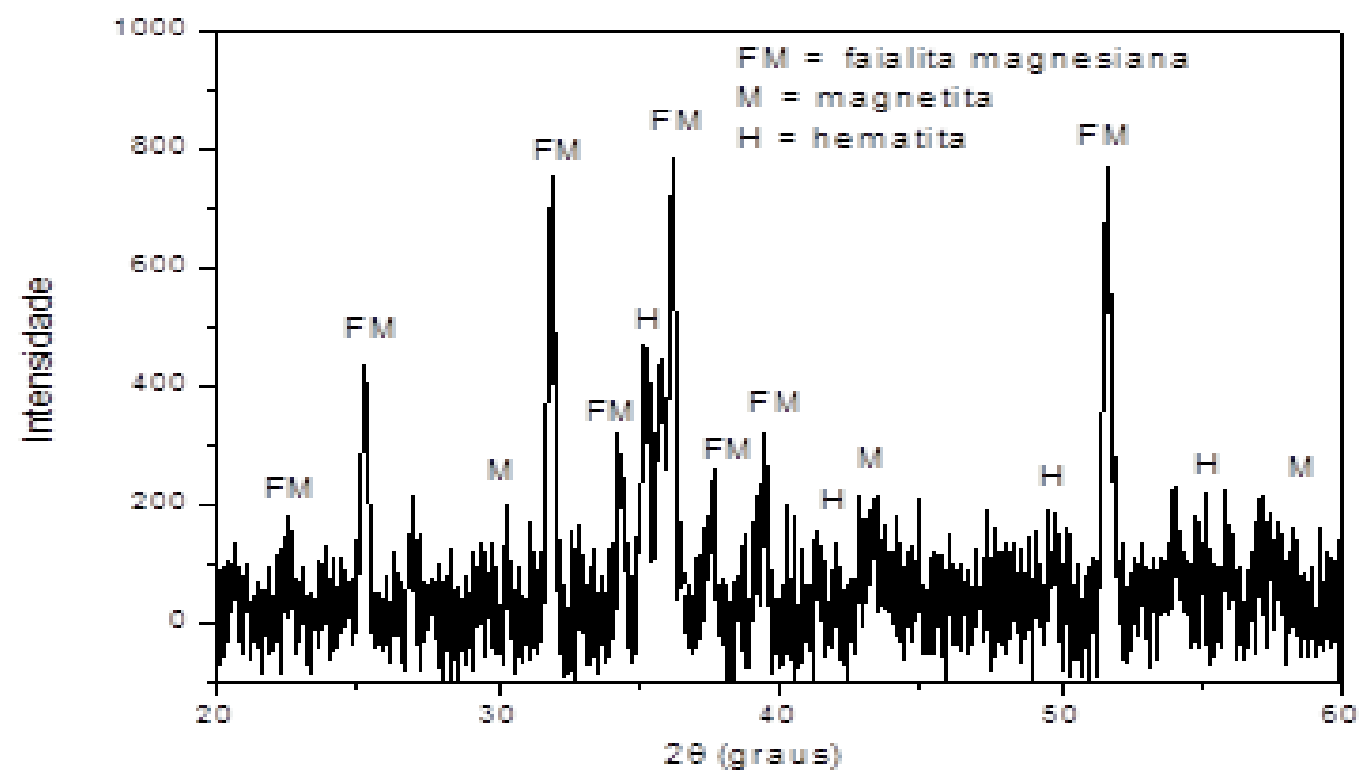

Figura 4.6 Difratograma de raios X da escória de cobre pós-jateada. 


\section{3}

\section{Caracterização das misturas de solo e escória de cobre}

A Figura 4.7 mostra as curvas granulométricas dos ensaios realizados com as amostras E.1 e E.2 de cada mistura de solo e as porcentagens de 10, 20, 30 e 40\% de escória de cobre pós-jateada utilizada nessa pesquisa, enquanto a Tabela 4.12 apresenta as porcentagens dessas misturas que passam nas respectivas peneiras para os dois ensaios. Um resumo da granulometria média, segundo a AASHTO (1973), está apresentado no histograma da Figura 4.8. Cada porcentagem de escória referese à massa de solo seco.

A densidade real das misturas está apresentada na Tabela 4.13. Observa-se que a densidade cresce com o aumento do teor de escória, devido a sua elevada densidade, porém, esse aumento não é constante.

Os limites de Atterberg estão apresentados na Tabela 4.14. Observa-se que ao se adicionar a escória de cobre pós-jateada, os valores dos limites de liquidez e plasticidade vão reduzindo o que pode ser atribuído às maiores porcentagens da fração areia presente na escória com baixa absorção $(0,33 \%)$.

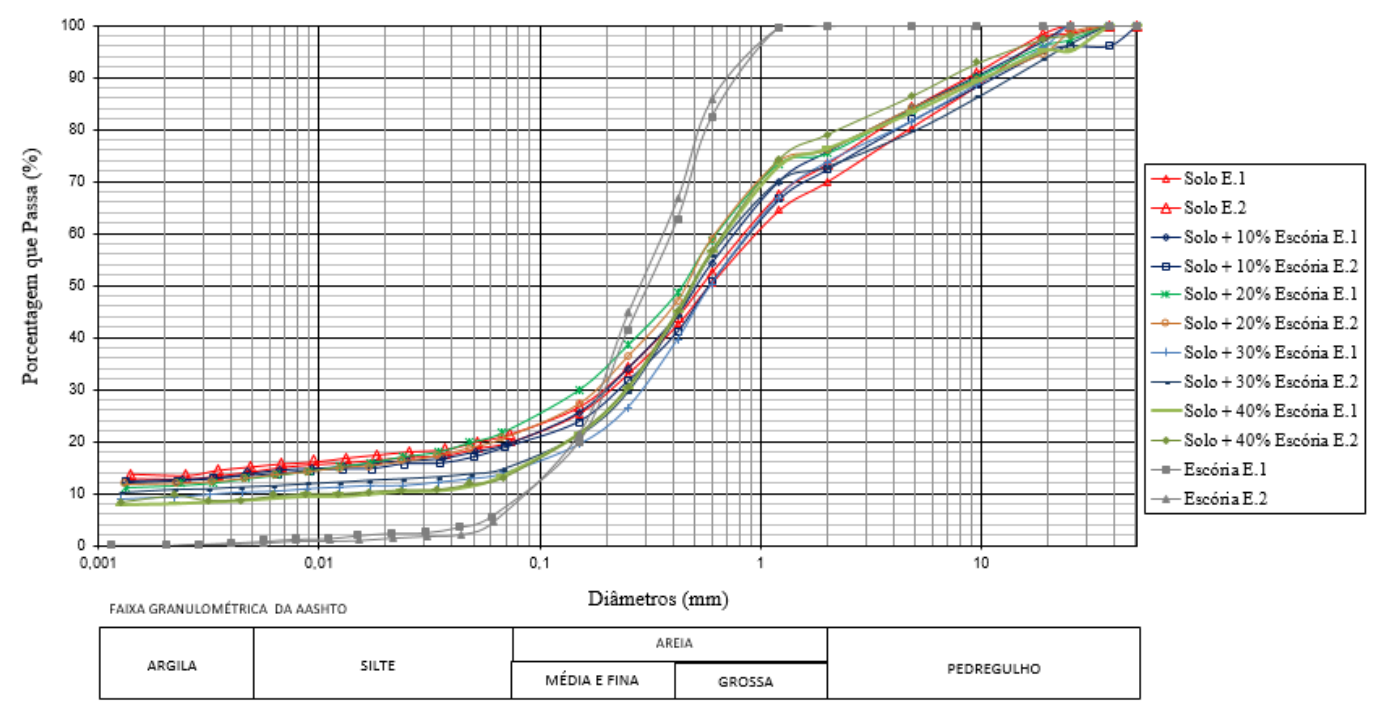

Figura 4.7 Curvas granulométricas das amostras de solo, de misturas e de escória de cobre pósjateada. 
Tabela 4.12 Resultado da análise granulométrica de misturas solo-escória de cobre pós-jateada.

\begin{tabular}{|c|c|c|c|c|}
\hline \multicolumn{2}{|c|}{ Peneira } & E. 1 & E. 2 & Média \\
\hline \multirow{13}{*}{ 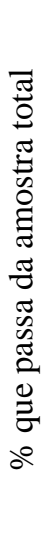 } & $2 "$ & 100 & 100 & 100 \\
\hline & $11 / 2 "$ & 100 & 96,15 & 98,08 \\
\hline & $1 "$ & 100 & 96,15 & 98,08 \\
\hline & $3 / 4 "$ & 96,95 & 94,90 & 95,93 \\
\hline & $3 / 8 "$ & 90,19 & 88,17 & 89,18 \\
\hline & $n^{\circ} 4$ & 84,00 & 81,60 & 82,80 \\
\hline & $n^{\circ} 10$ & 75,70 & 72,29 & 74,00 \\
\hline & $n^{\circ} 16$ & 69,86 & 66,31 & 68,09 \\
\hline & $n^{\circ} 30$ & 54,27 & 50,65 & 52,46 \\
\hline & $n^{\circ} 40$ & 44,31 & 41,09 & 42,70 \\
\hline & $n^{\circ} 60$ & 34,04 & 31,57 & 32,81 \\
\hline & $\mathrm{n}^{\circ} 100$ & 25,61 & 23,75 & 24,68 \\
\hline & $\mathrm{n}^{\circ} 200$ & 20,92 & 19,48 & 20,20 \\
\hline
\end{tabular}

\begin{tabular}{|c|c|c|c|c|}
\hline \multicolumn{2}{|c|}{ Peneira } & E. 1 & E. 2 & Média \\
\hline \multirow{13}{*}{ 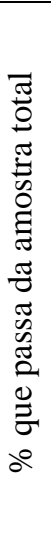 } & $2 "$ & 100 & 100 & 100 \\
\hline & $11 / 2 "$ & 100 & 100 & 100 \\
\hline & $1 "$ & 97,17 & 98,70 & 97,94 \\
\hline & $3 / 4 "$ & 95,97 & 94,61 & 95,29 \\
\hline & $3 / 8 "$ & 89,81 & 89,46 & 89,64 \\
\hline & $n^{\circ} 4$ & 83,64 & 84,01 & 83,83 \\
\hline & $\mathrm{n}^{\circ} 10$ & 75,33 & 76,05 & 75,69 \\
\hline & $n^{\circ} 16$ & 73,25 & 73,79 & 73,52 \\
\hline & $n^{\circ} 30$ & 58,76 & 59,05 & 58,91 \\
\hline & $n^{\circ} 40$ & 48,58 & 47,03 & 47,81 \\
\hline & $n^{\circ} 60$ & 38,48 & 36,33 & 37,41 \\
\hline & $n^{\circ} 100$ & 29,88 & 27,19 & 28,54 \\
\hline & $n^{\circ} 200$ & 23,97 & 21,59 & 22,78 \\
\hline
\end{tabular}

\begin{tabular}{|c|c|c|c|c|}
\hline \multicolumn{2}{|r|}{ Peneira } & E. 1 & E. 2 & Média \\
\hline \multirow{13}{*}{ 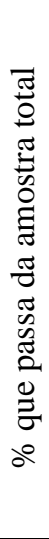 } & $2 "$ & 100 & 100 & 100 \\
\hline & $11 / 2 "$ & 100 & 100 & 100 \\
\hline & $1 "$ & 100 & 96,52 & 98,26 \\
\hline & $3 / 4 "$ & 95,67 & 93,51 & 94,59 \\
\hline & $3 / 8 "$ & 88,53 & 86,06 & 87,29 \\
\hline & $n^{\circ} 4$ & 81,44 & 79,42 & 80,43 \\
\hline & $\mathrm{n}^{\circ} 10$ & 73,61 & 72,82 & 73,22 \\
\hline & $\mathrm{n}^{\circ} 16$ & 66,87 & 69,98 & 68,43 \\
\hline & $n^{\circ} 30$ & 50,28 & 55,89 & 53,08 \\
\hline & $n^{\circ} 40$ & 39,55 & 44,09 & 41,82 \\
\hline & $n^{\circ} 60$ & 26,47 & 29,39 & 27,93 \\
\hline & $\mathrm{n}^{\circ} 100$ & 19,40 & 21,09 & 20,24 \\
\hline & $\mathrm{n}^{\circ} 200$ & 14,88 & 15,98 & 15,43 \\
\hline
\end{tabular}

\begin{tabular}{|c|c|c|c|c|}
\hline \multicolumn{2}{|c|}{ Peneira } & E. 1 & E. 2 & Média \\
\hline \multirow{13}{*}{ 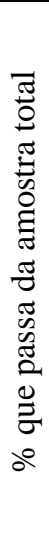 } & $2 "$ & 100 & 100 & 100 \\
\hline & $11 / 2 "$ & 100 & 100 & 100 \\
\hline & $1 "$ & 95,20 & 98,15 & 96,68 \\
\hline & $3 / 4 "$ & 95,20 & 97,39 & 96,30 \\
\hline & $3 / 8 "$ & 89,31 & 92,68 & 90,99 \\
\hline & $n^{\circ} 4$ & 83,32 & 86,34 & 84,83 \\
\hline & $\mathrm{n}^{\circ} 10$ & 76,39 & 79,06 & 77,73 \\
\hline & $\mathrm{n}^{\circ} 16$ & 72,92 & 74,16 & 73,54 \\
\hline & $\mathrm{n}^{\circ} 30$ & 56,48 & 56,68 & 56,58 \\
\hline & $\mathrm{n}^{\circ} 40$ & 44,99 & 45,13 & 45,06 \\
\hline & $\mathrm{n}^{\circ} 60$ & 30,30 & 30,49 & 30,39 \\
\hline & $\mathrm{n}^{\circ} 100$ & 21,42 & 21,57 & 21,49 \\
\hline & $\mathrm{n}^{\circ} 200$ & 14,92 & 15,12 & 15,02 \\
\hline
\end{tabular}

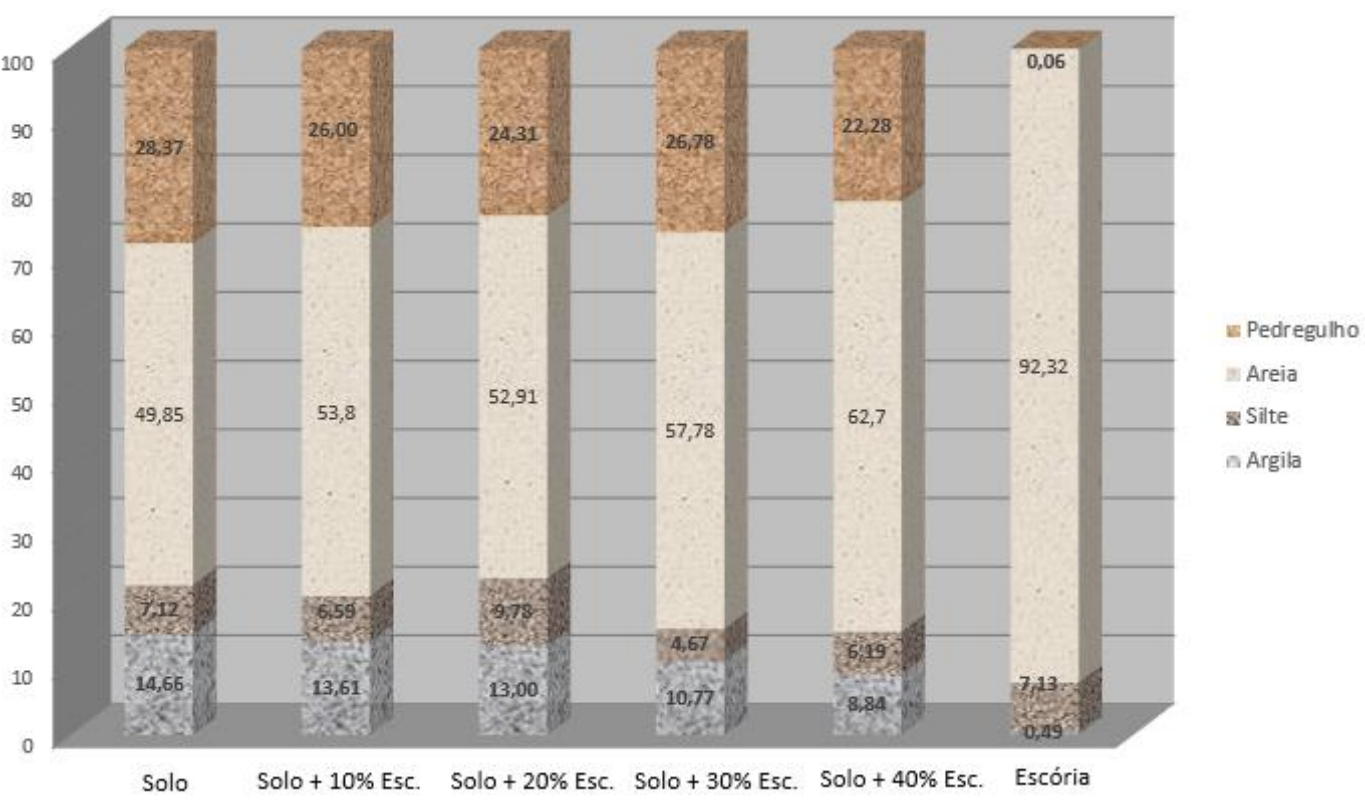

Figura 4.8 Histograma da granulometria das misturas solo-escória de cobre pós-jateada. 
Tabela 4.13 Densidade real dos grãos da mistura solo e escória de cobre pós-jateada.

\begin{tabular}{l|c}
\multicolumn{1}{c|}{ Amostra } & Densidade $\left(\mathrm{G}_{\mathrm{s}}\right)$ \\
\hline Solo & 2,69 \\
\hline Solo + 10 \% Escória & 2,80 \\
Solo + 20\% Escória & 2,85 \\
Solo + 30\% Escória & 2,98 \\
Solo + 40\% Escória & 3,05 \\
\hline Escória & 3,73 \\
\hline
\end{tabular}

Tabela 4.14 Limites de Atterberg da mistura solo e escória de cobre pós-jateada.

\begin{tabular}{c|cc|cc|cc|cc|cc|c}
\hline $\begin{array}{c}\text { Limites de } \\
\text { Atterberg }\end{array}$ & \multicolumn{2}{|c|}{ Solo } & \multicolumn{2}{|c|}{$\begin{array}{c}\text { Solo }+10 \% \\
\text { Escória }\end{array}$} & \multicolumn{2}{|c|}{$\begin{array}{c}\text { Solo }+20 \% \\
\text { Escória }\end{array}$} & \multicolumn{2}{c|}{$\begin{array}{c}\text { Solo }+30 \% \\
\text { Escória }\end{array}$} & \multicolumn{2}{c|}{$\begin{array}{c}\text { Solo + 40\% } \\
\text { Escória }\end{array}$} & Escória \\
\cline { 2 - 12 } & E.1 & E.2 & E.1 & E.2 & E.1 & E.2 & E.1 & E.2 & E.1 & E.2 & E.1 \\
\hline LL & 34 & 35 & 30 & 28 & 26 & 26 & 23 & 23 & 20 & 19 & NP \\
LP & 18 & 18 & 17 & 18 & 16 & 16 & 13 & 14 & 13 & 13 & NP \\
IP & 16 & 17 & 13 & 10 & 10 & 10 & 10 & 9 & 7 & 6 & NP \\
\hline
\end{tabular}

E.1 - ensaio 1; E.2 - ensaio 2

A Tabela 4.15 apresenta os dados referentes à média das porcentagens de material passando nas peneiras $\mathrm{N}^{\circ} 4(\# 4,8 \mathrm{~mm}), \mathrm{N}^{\circ} 10(\# 2,0 \mathrm{~mm}), \mathrm{N}^{\circ} 40(0,42 \mathrm{~mm})$ e $\mathrm{N}^{\mathrm{o}} 200(0,074 \mathrm{~mm})$. Além desses dados, a tabela também apresenta os resultados dos ensaios de limites de Atterberg, índice de grupo (IG) e a classificação dos solos segundo os sistemas AASHTO/TRB e USCS.

Comparando-se a granulometria do solo com a das misturas, observa-se que maiores variações ocorreram com as frações areia, silte e argila, que podem ser atribuídas aos teores crescentes de escória de cobre pós-jateada. Na fração arenosa, os 92,32\% de areia presente na escória dão uma maior contribuição, principalmente as porções média e fina. Em relação ao silte e argila, suas variações estão mais relacionadas à redução do teor de solo em detrimento do aumento do teor de escória, uma vez que para essa fração a escória apresenta baixa porcentagem (7,62\%). Em relação à classificação da mistura, houve uma mudança de classe quando se adicionou $20 \%$ de escória atribuída pela redução do índice de plasticidade de 16, para o solo puro, caindo para 10 , na mistura com $20 \%$ de escória. 
Tabela 4.15 Dados de parte da granulometria, limites de Atterberg, índice de grupo e classificação da mistura de solo e escória de cobre pós-jateada.

\begin{tabular}{l|c|c|c|c|c|c|c|c|c}
\hline \multicolumn{5}{c|}{ Composição granulométrica } & \multirow{2}{*}{$\begin{array}{c}\mathrm{L}_{\mathrm{L}} \\
(\%)\end{array}$} & $\begin{array}{c}\mathrm{I}_{\mathrm{P}} \\
(\%)\end{array}$ & \multirow{2}{*}{ IG } & \multicolumn{2}{c}{$\begin{array}{c}\text { Classificação da } \\
\text { amostra }\end{array}$} \\
\cline { 1 - 4 } \multicolumn{1}{c}{ Amostra } & $\# 4$ & $\# 10$ & $\# 40$ & $\# 200$ & & & & AASHTO/TRB & USCS \\
\hline Solo & 82,12 & 71,62 & 43,20 & 21,78 & 34 & 16 & 0 & A-2-6 & SC \\
\hline Solo + 10\% Escória & 82,80 & 74,00 & 42,70 & 20,20 & 29 & 12 & 0 & A-2-6 & SC \\
Solo + 20\% Escória & 83,83 & 75,69 & 47,81 & 22,78 & 26 & 10 & 0 & A-2-4 & SC \\
Solo + 30\% Escória & 80,43 & 73,22 & 41,82 & 15,43 & 23 & 9 & 0 & A-2-4 & SC \\
Solo + 40\% Escória & 84,83 & 77,73 & 45,06 & 15,02 & 19 & 7 & 0 & A-2-4 & SC \\
\hline Escória & 100 & 99,94 & 64,57 & 7,62 & NP & NP & 0 & A-3 & SP \\
\hline
\end{tabular}

A Tabela 4.16 mostra os valores da massa específica aparente seca máxima e a umidade ótima para as misturas de solo e diferentes porcentagens da escória de cobre pós-jateada.

Tabela 4.16 Peso específico aparente seca máximo e umidade ótima das misturas solo e escória de cobre pós-jateada.

\begin{tabular}{l|c|c}
\multicolumn{1}{c|}{ Amostra } & $\gamma_{\mathrm{dmáx}}\left(\mathrm{kN} / \mathrm{m}^{3}\right)$ & $\omega_{\text {ótima }}(\%)$ \\
\hline Solo & 21,07 & 8,9 \\
\hline Solo + 10\% Escória & 21,73 & 8,5 \\
Solo + 20\% Escória & 22,28 & 8,0 \\
Solo + 30\% Escória & 22,82 & 7,7 \\
Solo + 40\% Escória & 23,13 & 7,2 \\
\hline
\end{tabular}

Observa-se que há um aumento do peso específico e uma redução na umidade ótima à medida que o teor de escória cresce. Apesar da redução da quantidade de solo em favor do acréscimo de escória, a densidade dos grãos da escória é maior que a do solo, o que contribui para o aumento nos valores do peso específico. Associado a essa redução de solo, reduz também o número de partículas que absorveria água, somando-se ainda a baixa absorção por parte dos grãos da escória $(0,33 \%)$ e, como consequência, redução na umidade ótima.

Os resultados dos ensaios de resistência à compressão simples (RCS) e respectivas umidades de moldagem dos corpos de prova das misturas estão apresentados na Tabela 4.17. 
Tabela 4.17 Resistência à compressão simples das misturas solo e escória de cobre pós-jateada.

\begin{tabular}{|c|c|c|c|c|c|}
\hline Amostra & $\begin{array}{c}\mathrm{RCS} \\
(\mathrm{MPa})\end{array}$ & $\begin{array}{l}\text { Média } \\
(\mathrm{MPa})\end{array}$ & $\begin{array}{l}\text { Desvio } \\
\text { Padrão }\end{array}$ & $\begin{array}{c}\text { Umidade de } \\
\text { moldagem (\%) }\end{array}$ & $\begin{array}{l}\text { Umidade } \\
\text { ótima (\%) }\end{array}$ \\
\hline Solo & $\begin{array}{l}0,72 \\
0,90 \\
0,90\end{array}$ & 0,84 & $\pm 0,06$ & $\begin{array}{l}9,0 \\
8,2 \\
8,6\end{array}$ & 8,9 \\
\hline $\begin{array}{c}\text { Solo }+10 \% \\
\text { Escória }\end{array}$ & $\begin{array}{l}0,90 \\
0,85 \\
0,76\end{array}$ & 0,84 & $\pm 0,04$ & $\begin{array}{l}8,4 \\
8,2 \\
8,2\end{array}$ & 8,5 \\
\hline $\begin{array}{c}\text { Solo }+20 \% \\
\text { Escória }\end{array}$ & $\begin{array}{l}0,87 \\
0,78 \\
1,02\end{array}$ & 0,89 & $\pm 0,07$ & $\begin{array}{l}7,1 \\
7,9 \\
7,8\end{array}$ & 8,0 \\
\hline $\begin{array}{c}\text { Solo }+30 \% \\
\text { Escória }\end{array}$ & $\begin{array}{l}0,92 \\
0,91 \\
1,01\end{array}$ & 0,95 & $\pm 0,03$ & $\begin{array}{l}8,0 \\
7,7 \\
7,3\end{array}$ & 7,7 \\
\hline $\begin{array}{c}\text { Solo }+40 \% \\
\text { Escória }\end{array}$ & $\begin{array}{l}0,88 \\
0,97 \\
0,70\end{array}$ & 0,85 & $\pm 0,08$ & $\begin{array}{l}7,4 \\
7,1 \\
6,8\end{array}$ & 7,2 \\
\hline
\end{tabular}

Observa-se que os valores de RCS apresentaram valores próximos e as mesmas dificuldades descritas anteriormente nos ensaios para o solo puro também foram sentidas na moldagem das misturas, no que se refere ao acréscimo de água. Comparando as umidades, ora indica uma tendência de que quando o solo moldado na umidade ótima ou ligeiramente superior apresenta uma resistência maior, ora não confirma essa tendência.

A morfologia angulosa e pontiaguda dos grãos da escória, como visto na microscopia, pode contribuir com a resistência da mistura, uma vez que essa forma cria um "travamento" entre as partículas do solo e da escória impedindo de deslizarem uma sobre as outras, resultando numa maior resistência. Das misturas estudadas, o melhor teor obtido foi para a mistura com 30\% de escória, para a qual a RCS média foi de 0,95 MPa, indicando uma melhor estabilização granulométrica. Para o teor de $40 \%$ de escória houve queda na resistência, o que pode ser atribuída ao aumento da fração areia, devido a adição de escória, com consequente redução do solo, que faz diminuir a porção coesiva da mistura.

Com base nos resultados dos ensaios de resistência foi realizada uma análise de variância (ANOVA) com nível de confiabilidade de 95\%, a partir da qual ficou constatado que não há diferença significativa entre os tratamentos, isto é, não há 
evidências de que o acréscimo, até $40 \%$ de escória, produza diferenças estatísticas entre as amostras analisadas (Figura 4.9).

Considerando a melhor mistura, aquela que incorpora $30 \%$ de escória de cobre, foram realizados o ensaio de permeabilidade de carga variável, dos quais se obteve um coeficiente de permeabilidade médio igual a $7,0 \times 10^{-5} \mathrm{~cm} / \mathrm{s}$ para a mistura solo-escória, cujo valor quando comparado ao do solo puro $\left(\mathrm{k}=1,4 \times 10^{-4}\right.$ $\mathrm{cm} / \mathrm{s}$ ), conclui-se que a escória, ao contrário do que se poderia prognosticar, promoveu redução da permeabilidade. A Figura 4.10 mostra as imagens obtidas por MEV para essa mistura. Pode-se observar na Figura 4.10a a presença de canalículos por onde a água percola, com uma aproximação na Figura 4.10b. A redução na permeabilidade está condicionada ao entrosamento dos grãos da escória e do solo, em que o resíduo atua preenchendo os vazios deixados pelas partículas do solo, resultando, dessa forma, em uma melhor estabilização granulométrica, reduzindo a interconexão daqueles canalículos.

Visando avaliar alterações na plasticidade das misturas após o rompimento à compressão, os resultados dos limites de Atterberg das misturas solo e escória de cobre pós-jateada estão apresentados na Tabela 4.18. Comparando com os valores dos limites anteriormente apresentados (Tabela 4.14) e depois do ensaio de RCS, observa-se que não houve maiores variação na plasticidade das misturas, indicando que a compactação com energia Proctor intermediária para a moldagem dos corpos de prova não foi suficiente para quebrar os grãos nem do solo nem da escória de cobre para alterar os limites. 
$\%$ de Escória

Solo puro Solo c/ $10 \%$ escória Solo c/ $20 \%$ escória Solo c/ 30\% escória Solo c/ $40 \%$ escória

$\begin{array}{lllll}0,72 & 0,9 & 0,87 & 0,92 & 0,88 \\ 0,9 & 0,85 & 0,78 & 0,91 & 0,97 \\ 0,9 & 0,76 & 1,02 & 1,01 & 0,7\end{array}$

Anova: fator único

RESUMO

\begin{tabular}{llrrrr}
\hline \multicolumn{1}{c}{ Grupo } & Contagem & Soma & Média & Variância \\
\hline Solo puro & 3 & 2,52 & 0,84 & 0,0108 \\
Solo c/ 10\% escória & 3 & 2,51 & 0,84 & 0,0050 \\
Solo c/ 20\% escória & 3 & 2,67 & 0,89 & 0,0147 \\
Solo c/ 30\% escória & 3 & 2,84 & 0,95 & 0,0030 \\
Solo c/ 40\% escória & 3 & 2,55 & 0,85 & 0,0189 \\
\hline
\end{tabular}

\begin{tabular}{|c|c|c|c|c|c|c|}
\hline Fonte da variação & $S Q$ & $g l$ & $M Q$ & $F$ & valor- $P$ & F crítico \\
\hline Entre grupos & 0,02596 & 4 & 0,00649 & 0,61849 & 0,65947 & 3,47805 \\
\hline Dentrodos grupos & 0,10493 & 10 & 0,01049 & & & \\
\hline Total & 0,13089 & 14 & & & & \\
\hline
\end{tabular}

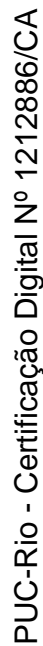

(a)

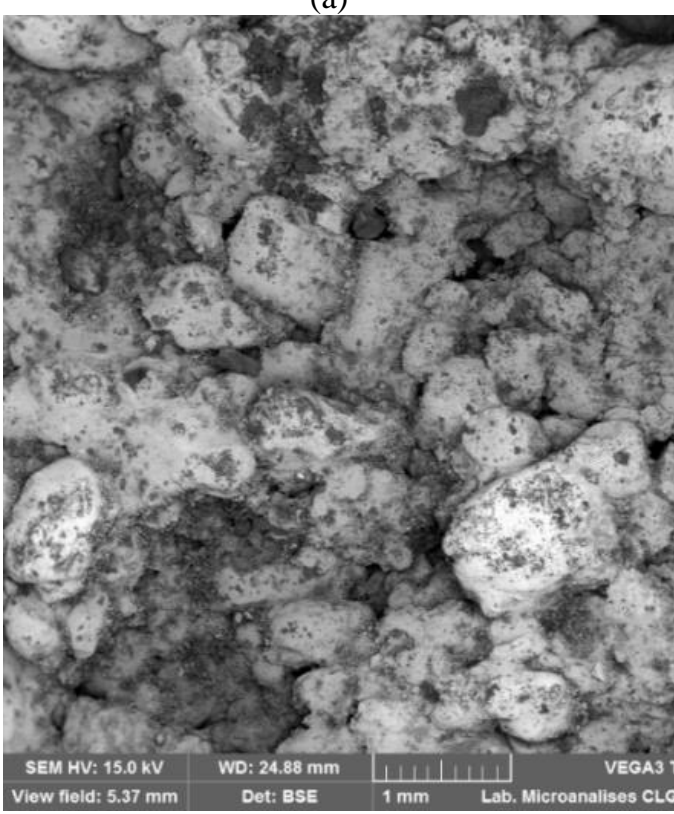

(b)

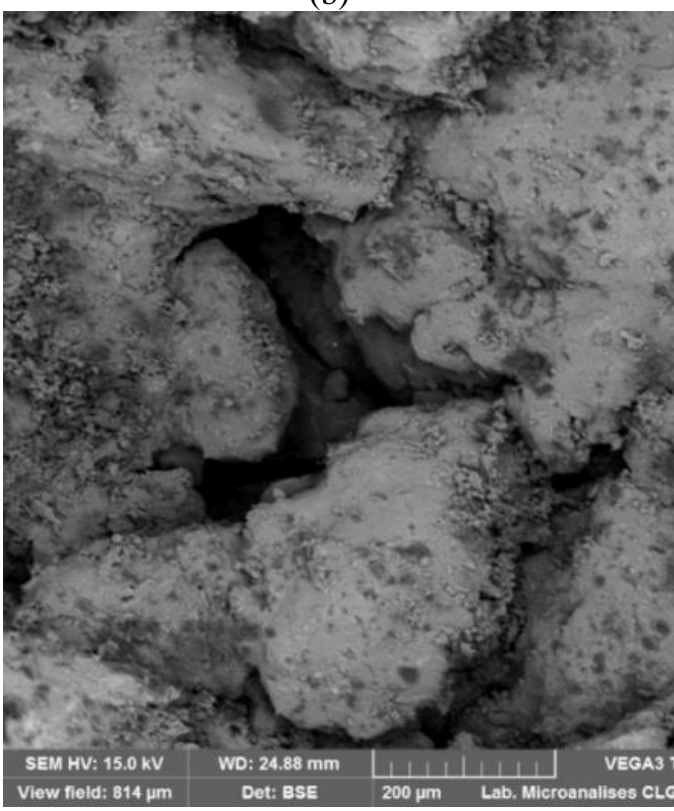

Figura 4.10 Microscopia eletrônica de varredura da mistura solo e 30\% de escória de cobre pósjateada. 
Tabela 4.18 Limites de Atterberg da mistura solo e escória de cobre pós-jateada de amostras pósRCS.

\begin{tabular}{c|cc|cc|cc|cc|cc}
\hline \multirow{2}{*}{$\begin{array}{c}\text { Limites de } \\
\text { Atterberg }\end{array}$} & \multicolumn{2}{|c|}{ Solo } & \multicolumn{2}{c|}{$\begin{array}{c}\text { Solo }+10 \% \\
\text { Escória }\end{array}$} & \multicolumn{2}{c|}{$\begin{array}{c}\text { Solo + 20\% } \\
\text { Escória }\end{array}$} & \multicolumn{2}{c|}{$\begin{array}{c}\text { Solo + 30\% } \\
\text { Escória }\end{array}$} & \multicolumn{2}{c}{$\begin{array}{c}\text { Solo + 40\% } \\
\text { Escória }\end{array}$} \\
\cline { 2 - 11 } & E.1 & E.2 & E.1 & E.2 & E.1 & E.2 & E.1 & E.2 & E.1 & E.2 \\
\hline LL & 33 & 34 & 28 & 29 & 22 & 22 & 22 & 22 & 21 & 21 \\
LP & 18 & 18 & 16 & 17 & 13 & 14 & 13 & 13 & 13 & 14 \\
IP & 15 & 16 & 12 & 12 & 9 & 8 & 9 & 9 & 8 & 7 \\
\hline
\end{tabular}

E.1 - ensaio 1; E.2 - ensaio 2

\section{4 \\ Caracterização das misturas de solo e cimento Portland e dosagem do aditivo}

A Tabela 4.19 mostra os valores do peso específico aparente seco máximo e a umidade ótima para as misturas de solo e os teores de cimento Portland. Os resultados mostram que não há maiores variações nos valores da massa específica, mas há uma tendência de reduzir a umidade ótima à medida que se aumenta o teor de cimento. Conforme consta na literatura, é importante a mistura estar a uma umidade ótima capaz de promover a máxima densificação e a completa hidratação do cimento.

Através da metodologia de dosagem apresentada no capítulo anterior foi realizada a dosagem preliminar do solo e cimento. O gráfico apresentado na Figura 4.11 indica que os teores ideais para a satisfação físico-química variam de 3 a $5 \%$ de cimento, atribuído às maiores variações volumétricas ocorridas nos dois ensaios de aproximadamente $190 \%$ e $150 \%$. Foram realizados dois ensaios, pois houve dúvidas quanto ao teor que satisfizesse físico-quimicamente o solo estudado. Macêdo (2004) obteve uma dosagem bastante semelhante para três teores de cimento em um solo A-2-4 do Estado de Pernambuco.

Tabela 4.19 Peso específico aparente seco máximo e umidade ótima das misturas solo e cimento Portland.

\begin{tabular}{l|c|c}
\hline \multicolumn{1}{c|}{ Amostra } & $\gamma_{\text {dmáx }}\left(\mathrm{kN} / \mathrm{m}^{3}\right)$ & $\omega_{\text {ótima }}(\%)$ \\
\hline Solo & 21,07 & 8,9 \\
\hline Solo + 3\% Cimento & 21,12 & 8,9 \\
Solo + 5\% Cimento & 21,46 & 8,8 \\
Solo + 7\% Cimento & 21,23 & 8,6 \\
Solo + 9\% Cimento & 21,31 & 8,5 \\
\hline
\end{tabular}




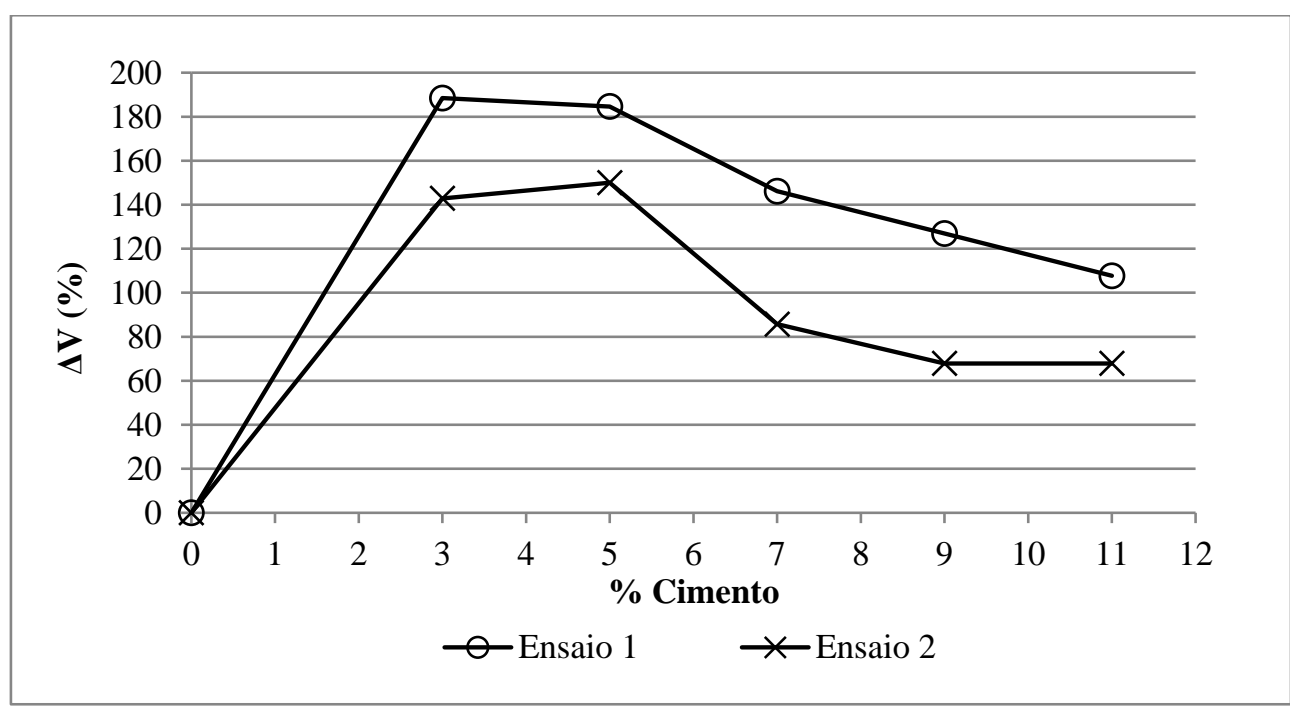

Figura 4.11 Dosagem físico-química do solo.

Uma vez que a dosagem físico-química é um método em que o teor de cimento é definido pela satisfação físico-química do solo com o cimento em uma solução aquosa (e.g. Ceratti, 1991; Casanova et al., 1992; Rodrigues, 1992, Macêdo, 2004), a dosagem solo-cimento descrita em norma leva em consideração uma resistência à compressão mínima igual a 2,1 MPa. No entanto, qualquer teor de cimento menor que o determinado pelo método físico-químico deixa de satisfazer o solo, deixando-o fora da nova situação de equilíbrio imposta pelo processo de estabilização, conforme descreve Casanova (1992). Dessa maneira, segundo o mencionado autor, é praticamente impossível se estabilizar um solo com um teor de cimento inferior ao determinado pelo método, além de que, esse teor pode ou não atingir o valor mínimo de resistência especificado em norma.

Tomando-se como teor inicial o valor obtido dessa dosagem físico-química, foi realizado o ensaio de RCS do solo para diferentes teores de cimento, e os resultados estão reunidos na Tabela 4.20.

A Figura 4.12 apresenta as curvas representativas de resistências para as amostras da mistura solo-cimento. 
Tabela 4.20 Resistência à compressão simples das misturas solo e cimento Portland.

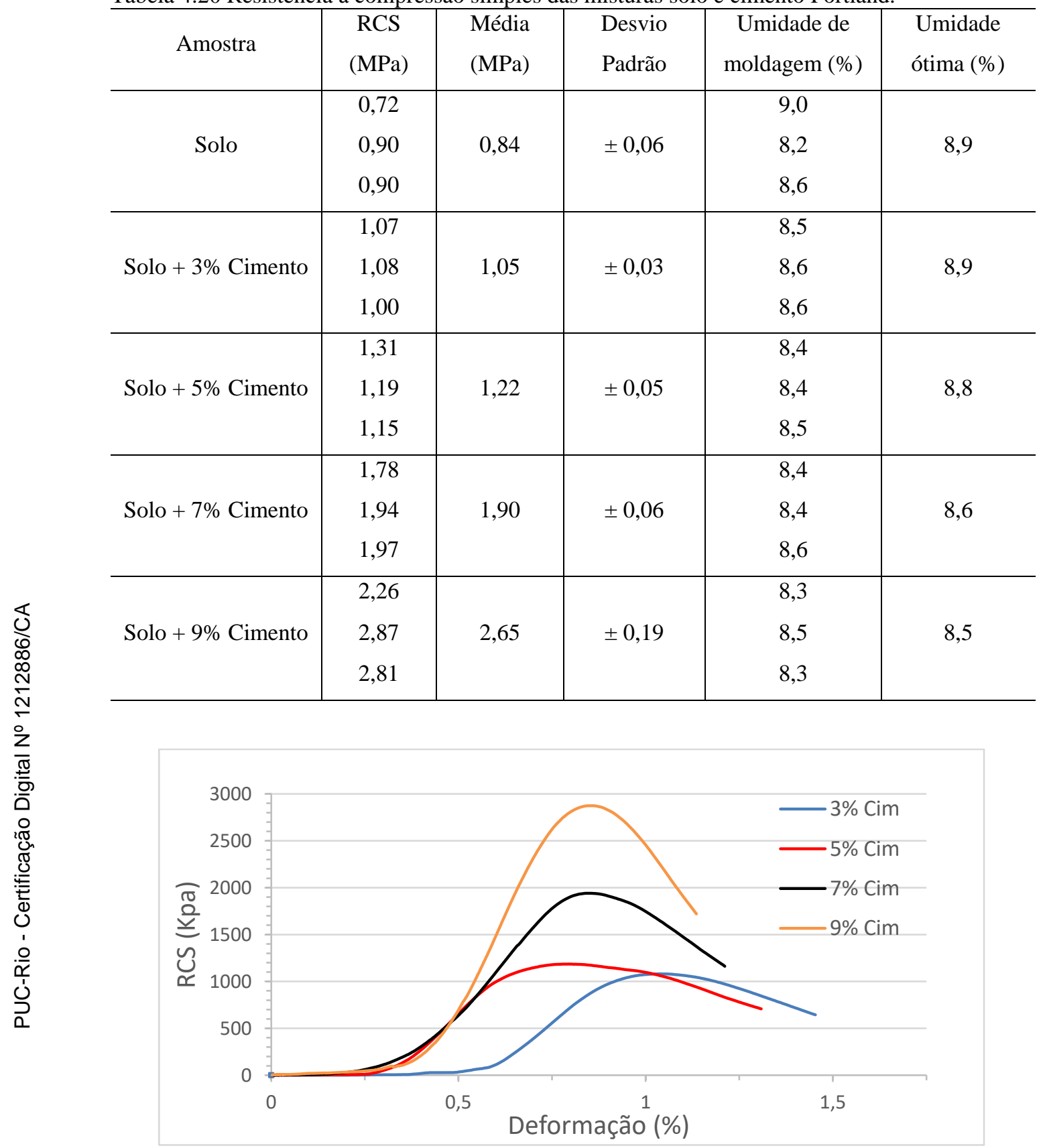

Figura 4.12 Curvas de RCS versus Deformação para misturas solo e cimento Portland.

A partir das curvas pode-se observar que, com o aumento no teor de cimento, há uma ligeira diminuição na deformação no pico de resistência, indicando uma maior rigidez do material. Nota-se que as misturas com $3 \%$ e $5 \%$ de cimento apresentaram uma maior tenacidade caracterizado pelo patamar no pico de resistência, isso indicando que houve um maior acumulo de energia para romper. Comportamento diferente para as misturas superiores, em que houve um aumento do pico de resistência tão logo o corpo de prova rompeu. A Figura 4.13 mostra o 
plano de ruptura de corpos de provas com teor de 3\% de cimento após serem rompidos.

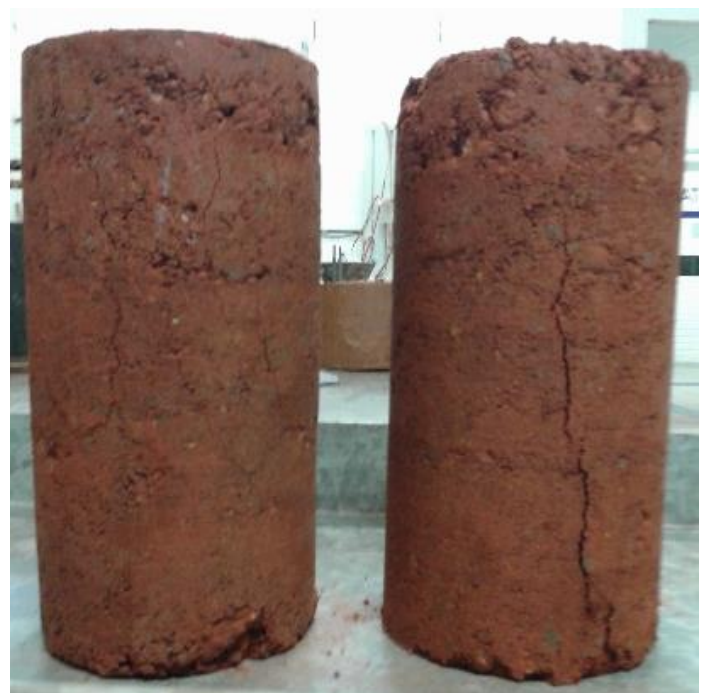

Figura 4.13 Ruptura de corpos de prova com 3\% de cimento após rompimento à compressão simples.

Dos ensaios observa-se claramente que o aumento no teor de cimento Portland causa um aumento na resistência da mistura e a variação desse aumento é maior quando o teor passa de 5\%, porém, atingindo uma resistência média de 2,65 MPa para um teor de $9 \%$. Essa resistência é cerca de $25 \%$ maior que a resistência mínima de 2,1 MPa tomada como referência segundo a norma DNIT 143/2010 ES. Diante desse resultado, o teor de cimento para esse solo fica em torno de 7 a $9 \%$ em relação à massa seca do solo. A Figura 4.14 é apresentado graficamente o crescimento da resistência com o teor de cimento.

Dos resultados apresentados, comprova-se que o teor obtido da dosagem físico-química não atingiu a resistência mínima, sendo esta atingida com teores superiores a cerca de $9 \%$ de cimento. No entanto, o método forneceu um teor mínimo do aditivo para promover uma ação modificadora do solo estudado, com alteração na plasticidade e pouco ganho de resistência. Para acréscimos de cimento fez elevar a resistência, além de que, essa dosagem serviu para uma rápida verificação da viabilidade do solo poder ou não ser estabilizado com cimento. 


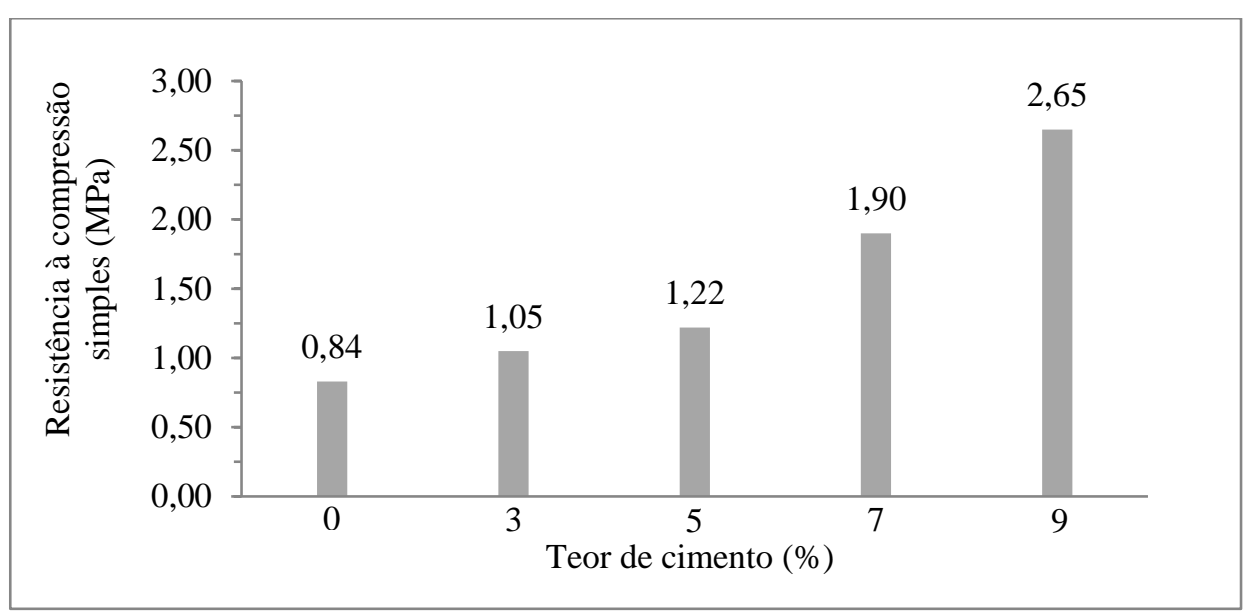

Figura 4.14 Resistência à compressão simples (MPa) versus teor de cimento (\%) do solo.

As curvas de variação volumétrica apresentadas por Casanova e Ceratti (1985) apud Ceratti (1991) mostram que o argilomineral influencia no teor de cimento da dosagem físico-química: a caulinita é o argilomineral que causa menor variação, seguida da ilita e, com maior variação, a montmorilonita. De acordo com Croft (1967), a caulinita juntamente com a ilita são mais suscetíveis a estabilização com cimento do que os argilominerais expansivos. O ensaio de difração do solo estudado, não detectou a montmorilonita, o que pode explicar uma baixa variação volumétrica.

Ao comparar a umidade de moldagem com a ótima, os corpos de prova foram moldados no ramo seco, porém, bem próximo à umidade ótima. No entanto, podese notar que para um mesmo teor de cimento e com a mesma umidade de moldagem a resistência sofreu uma variação máxima de 0,55 MPa para a amostra com 9\% de cimento e mínima de 0,08 MPa para 3\% do aditivo. Nota-se também que uma pequena variação no sentido de se aproximar à umidade ótima levou a maiores resistências. Nos estudos de Villar Filho et al. (1982) os resultados mostraram que a máxima resistência foi obtida com corpos de prova compactados no ramo seco, com umidade ligeiramente inferior à ótima. Consoli et al. (2007) mostraram que a variação no teor de umidade de moldagem afetou a resistência à compressão simples. Os autores observaram um aumento da resistência com o teor de umidade até um valor ótimo a partir do qual ocorreu um decréscimo na resistência. Essa alteração de resistência está provavelmente relacionada à estrutura criada no momento da moldagem e a quantidade de água adicionada teria um papel fundamental na formação da estrutura. 
Em relação ao ganho de resistência, há um modelo matriz-esqueleto proposto por Herzog (1967) e sumarizado de Rodrigues (1992) que explica tal ganho: numa argila, cuja estrutura é feita de domínios de tamanhos diferentes, existem vazios interconectados numa certa extensão - esses domínios consistem em placas de argila orientada paralelamente em pacotes fechados, comportando-se como unidades estruturais em argilas. A hidratação do cimento e a ocorrência de reações secundárias formam um corpo no qual o centro endurecido de cimento é rodeado por uma zona desses domínios argilosos que se unem por cimentação “interdomínio". Externamente a essa zona formam-se canais pelos macroporos interconectados dentro da massa argilosa que podem ficar revestidos de cimento e se apresentam como ramificações relativamente fortes e reforçadas, estendendo-se do corpo à matriz inalterada.

Rodrigues (1992) ainda descreve que se o conteúdo de cimento for muito baixo, tais unidades de esqueleto se comportam como partículas bem granulares e separadas, flutuando na matriz argilosa. Aumentando-se um pouco a quantidade de cimento, as unidades do esqueleto ficam menos espaçadas, porém não interconectadas. Já com teores maiores, o espaço entre elas é menor e as ramificações tornam-se interligadas, aumentando a resistência e a estabilidade da matriz argilosa. Para quantidades de cimento ainda maiores não há produção de matriz, sugerindo a formação de um esqueleto rígido, completamente interconectada, tornando-se maior fonte de resistência do sistema. A Figura 4.15 permite entender o modelo citado na mistura do solo com os teores 3, 5, 7 e $9 \%$ de cimento.

Observa-se das Figuras 4.15a e 4.15b que o cimento tem uma ação modificadora da fração argilosa que faz diminuir a plasticidade com pouca variação no ganho de resistência. No entanto, nas Figuras $4.15 \mathrm{c}$ e $4.15 \mathrm{~d}$ o cimento já apresenta uma ação aglutinante das partículas de solo permitindo um aumento da resistência mecânica. Percebe-se nos torrões a presença do cimento (pontos acinzentados em meio às partículas do solo), principalmente na amostra de $5 \%$ e na amostra de 7 e $9 \%$ o solo perde mais a tonalidade avermelhada, característica desse solo, e passa a apresentar uma coloração mais acinzentada devido à maior quantidade de cimento. 
(a)

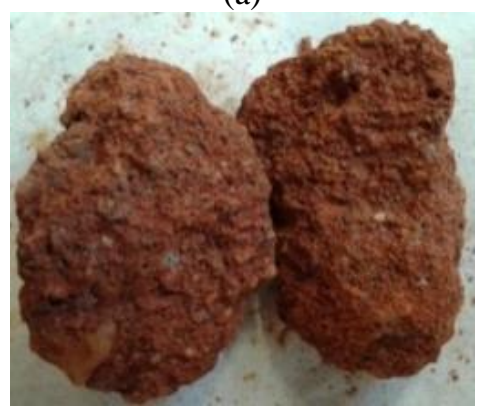

(c)

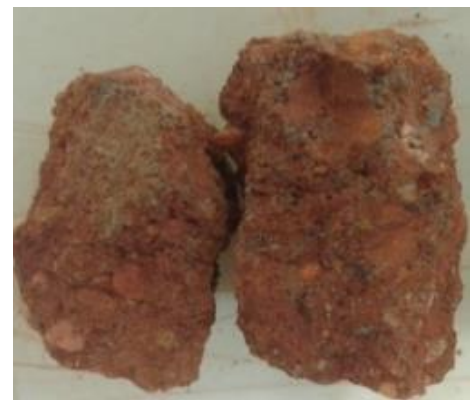

(b)

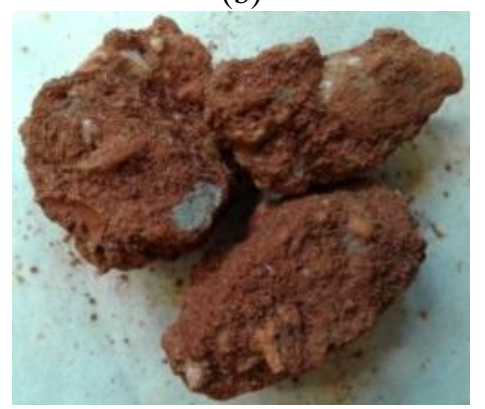

(d)

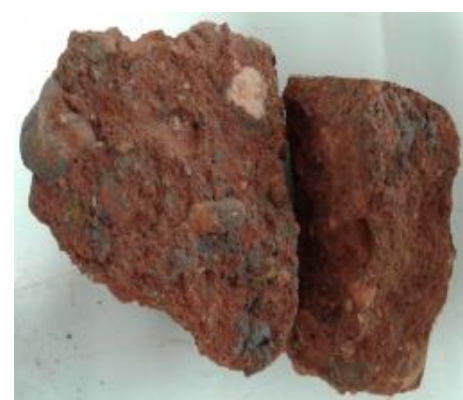

Figura 4.15 Torrões da mistura solo e 3\% (a), 5\% (b), $7 \%$ (c) e $9 \%$ (d) de cimento Portland, após o ensaio de RCS.

Considerando o teor de cimento obtido da dosagem físico-química e o teor obtido do ensaio de compressão simples, confirma-se que houve uma diferença significativa entre eles. Enquanto o teor obtido do ensaio de resistência ficou entre 7 e $9 \%$, a partir da dosagem físico-química esse teor situou-se entre 3 e $5 \%$, o que representa um aumento de pelo menos $80 \%$ na quantidade de cimento quando se emprega o método de dosagem baseado na resistência.

A análise de variância, com nível de confiabilidade de $95 \%$, mostrou que a adição de até $9 \%$ de cimento produz diferenças significativas entre os tratamentos, isto é, há diferenças estatísticas de resistência entre as misturas para os diferentes teores (Figura 4.16). Um teste Tukey mostrou que essas diferenças estão entre as seguintes misturas:

$\checkmark 7 \%$ de cimento em relação ao solo puro e às misturas com 3 e $5 \%$ do aditivo;

$\checkmark 9 \%$ de cimento em relação a todas as misturas ensaiadas. 
Solo - Cimento

$\begin{array}{ccccc}\text { Solo puro } & \text { Solo c/3\% cimento } & \text { Solo } / 5 \% \text { cimento } & \text { Solo } / 7 \% \text { cimento } & \text { Solo } / 9 \% \text { cimento } \\ 0,72 & 1,07 & 1,31 & 1,78 & 2,26 \\ 0,9 & 1,08 & 1,19 & 1,94 & 2,87 \\ 0,9 & 1 & 1,15 & 1,97 & 2,81\end{array}$

Anova: fator único

RESUMO

\begin{tabular}{llrrrr}
\hline \multicolumn{1}{c}{ Grupo } & Contagem & Soma & Média & \multicolumn{1}{c}{ Variância } \\
\hline Solo puro & 3 & 2,52 & 0,84 & 0,0108 \\
c/3\% cimento & 3 & 3,15 & 1,05 & 0,0019 \\
c/5\% cimento & 3 & 3,65 & 1,22 & 0,0069 \\
c/7\% cimento & 3 & 5,69 & 1,90 & 0,0104 \\
c/9\% cimento & 3 & 7,94 & 2,65 & 0,1130 \\
\hline
\end{tabular}

ANOVA

\begin{tabular}{|c|c|c|c|c|c|c|c|}
\hline Fonte da variação & $S Q$ & $g l$ & & $M Q$ & $F$ & valor-P & Fcritico \\
\hline Entre grupos & 6,5582 & & 4 & 1,63955 & 57,28686 & $7,4 \mathrm{E}-07$ & 3,47805 \\
\hline Dentro dos grupos & 0,2862 & & 10 & 0,02862 & & & \\
\hline
\end{tabular}

Total

6,8444

14

Figura 4.16 Análise de variância da \% de cimento Portland.

Ensaios de limites de Atterberg foram realizados para avaliar a perda de plasticidade com a adição de cimento ao solo. Nesse caso, as amostras da mistura para tais ensaios foram coletadas dos corpos de prova após serem rompidos à compressão. Os resultados estão apresentados na Tabela 4.21. Diante dos valores obtidos para esses limites, nota-se que a adição de $3 \%$ de cimento reduziu fortemente a plasticidade e a partir de $5 \%$, a mistura não apresenta mais essa característica, concordando com os conceitos básicos das misturas solo-cimento, em que o cimento Portland reduz a plasticidade do solo, sendo necessário tempo suficiente para ocorrer as reações de hidratação e endurecimento do cimento. Este fato pode ser entendido pela formação da matriz que fixa as partículas tal que elas não podem deslizar uma em relação às outras.

Ao comparar os valores dos limites das amostras pós-RCS entre as misturas solo-escória (Tabela 4.18) com solo-cimento (Tabela 4.21), foi possível realizar o ensaio para todas as porcentagens de escória, mas as misturas com percentual a partir de 3\% de cimento se apresentaram como não-plástica, indicando que a ação modificadora do cimento é mais efetiva na redução da plasticidade do que a adição de até $40 \%$ de escória. 
Tabela 4.21 Limites de Atterberg da mistura solo e cimento Portland de amostras pós-RCS

\begin{tabular}{|c|c|c|c|c|c|c|c|}
\hline \multirow{2}{*}{$\begin{array}{l}\text { Limites de } \\
\text { Atterberg }\end{array}$} & \multicolumn{2}{|c|}{ Solo } & \multicolumn{2}{|c|}{$\begin{array}{c}\text { Solo }+3 \% \\
\text { Cimento }\end{array}$} & $\begin{array}{l}\text { Solo }+5 \% \\
\text { Cimento }\end{array}$ & $\begin{array}{l}\text { Solo }+7 \% \\
\text { Cimento }\end{array}$ & $\begin{array}{c}\text { Solo }+9 \% \\
\text { Cimento }\end{array}$ \\
\hline & E. 1 & E. 2 & E.1 & E.2 & $\begin{array}{ll}\text { E. } 1 & \text { E. } 2\end{array}$ & $\begin{array}{ll}\text { E. } 1 & \text { E. } 2\end{array}$ & $\begin{array}{ll}\text { E. } 1 & \text { E. } 2\end{array}$ \\
\hline LL & 33 & 34 & 29 & 29 & \multirow{3}{*}{ NP } & \multirow{3}{*}{ NP } & \multirow{3}{*}{ NP } \\
\hline LP & 18 & 18 & 23 & 24 & & & \\
\hline IP & 15 & 16 & 6 & 5 & & & \\
\hline
\end{tabular}

E.1 - ensaio 1; E.2 - ensaio 2

\section{5}

Caracterização das misturas de solo, escória de cobre e cimento Portland

Após a caracterização dos materiais puros e em misturas, partiu-se para a incorporação da escória de cobre pós-jateada ao solo e cimento Portland para avaliar as alterações que o resíduo poderia promover para reduzir ou não o teor do aditivo, elevar, reduzir ou não a resistência da mistura e contribuir para uma destinação final do resíduo. Para a mistura com menor teor de cimento e com resistência maior que 2,1 MPa foi dada maior atenção para alguns ensaios, conforme será visto nas discussões desse tópico.

A Tabela 4.22 mostra os valores do peso específico aparente seco máximo e a umidade ótima para as misturas de solo, escória e teores de cimento Portland. Os resultados mostram que o peso específico cresce com teor de escória e com o teor de cimento, porém, esse crescimento está mais condicionado ao acréscimo da escória do que ao cimento devido a densidade elevada da escória, e, como visto no item anterior, não houve maiores variações no peso específico nas misturas de solo e cimento.

Com relação à umidade ótima, há uma tendência de reduzir ao acréscimo de escória e cimento e isso por está condicionado à redução do solo em favor das porcentagens crescentes de escória e cimento, o que reduz a parte que efetivamente absorveria maior parte da água. Além disso, a escória apresenta baixa capacidade de absorção, o que contribui para uma menor quantidade de água na mistura.

Uma observação feita durante os ensaios de compactação foi a não ocorrência do efeito "burrachudo" nas misturas acima de $20 \%$ de escória com e sem teores de cimento. Isso pode estar relacionado à maior quantidade da fração areia presente na 
escória, redução da fração argila do solo, além da elevada densidade dos grãos do resíduo.

Tabela 4.22 Peso específico aparente seco máximo e umidade ótima das misturas solo, escória de cobre pós-jateada e cimento Portland.

\begin{tabular}{c|c|c|c|c|c}
\multirow{2}{*}{$\begin{array}{c}\text { Teor de } \\
\text { cimento } \\
(\%)\end{array}$} & \multicolumn{6}{|c}{ Peso específico aparente seco máximo $\left(\mathrm{kN} / \mathrm{m}^{3}\right) / 4$} \\
\cline { 2 - 6 } & $0 \%$ Escória & $10 \%$ Escória & $20 \%$ Escória & $30 \%$ Escória & $40 \%$ Escória \\
\hline 0 & $21,07 / 8,9$ & $21,73 / 8,5$ & $22,28 / 8,0$ & $22,82 / 7,7$ & $23,13 / 7,2$ \\
\hline 3 & $21,12 / 8,9$ & $21,93 / 8,5$ & $22,50 / 7,5$ & $22,95 / 7,3$ & $23,39 / 7,5$ \\
\hline 5 & $21,46 / 8,8$ & $21,64 / 8,3$ & $22,59 / 7,8$ & $23,21 / 7,2$ & $23,30 / 7,1$ \\
\hline 7 & $21,23 / 8,6$ & $21,84 / 8,3$ & $*$ & $*$ & $*$ \\
\hline 9 & $21,31 / 8,5$ & $21,87 / 8,5$ & $*$ & $*$ & $*$ \\
\hline
\end{tabular}

A dosagem físico-química da mistura do solo e escória também foi realizada e apresentou um comportamento bastante diferente, tornando-se nítida a queda da variação volumétrica a partir de $3 \%$ de cimento Portland e com o acréscimo da escória. Para as porcentagens de 10 e $20 \%$ de escória foi obtido o mesmo teor de $3 \%$ de cimento, atribuída às maiores variações volumétricas ocorridas nos ensaios de aproximadamente $170 \%$ e $150 \%$. Dessa forma, infere-se que o menor teor de cimento para as porcentagens de $30 \%$ e $40 \%$ de escória também seja de $3 \%$ do aditivo para a satisfação físico-química. A Figura 4.17 representa graficamente a queda volumétrica com o teor de cimento.

Ao misturar porcentagens de escória de cobre pós-jateada incorporam-se ao solo puro frações granulométricas de areia e, assim, há tendência para menores teores de cimento, conforme descrito na teoria: solos mais arenosos de média a baixa plasticidade são os mais suscetíveis a serem estabilizados com cimento por requererem baixos teores do aditivo. 


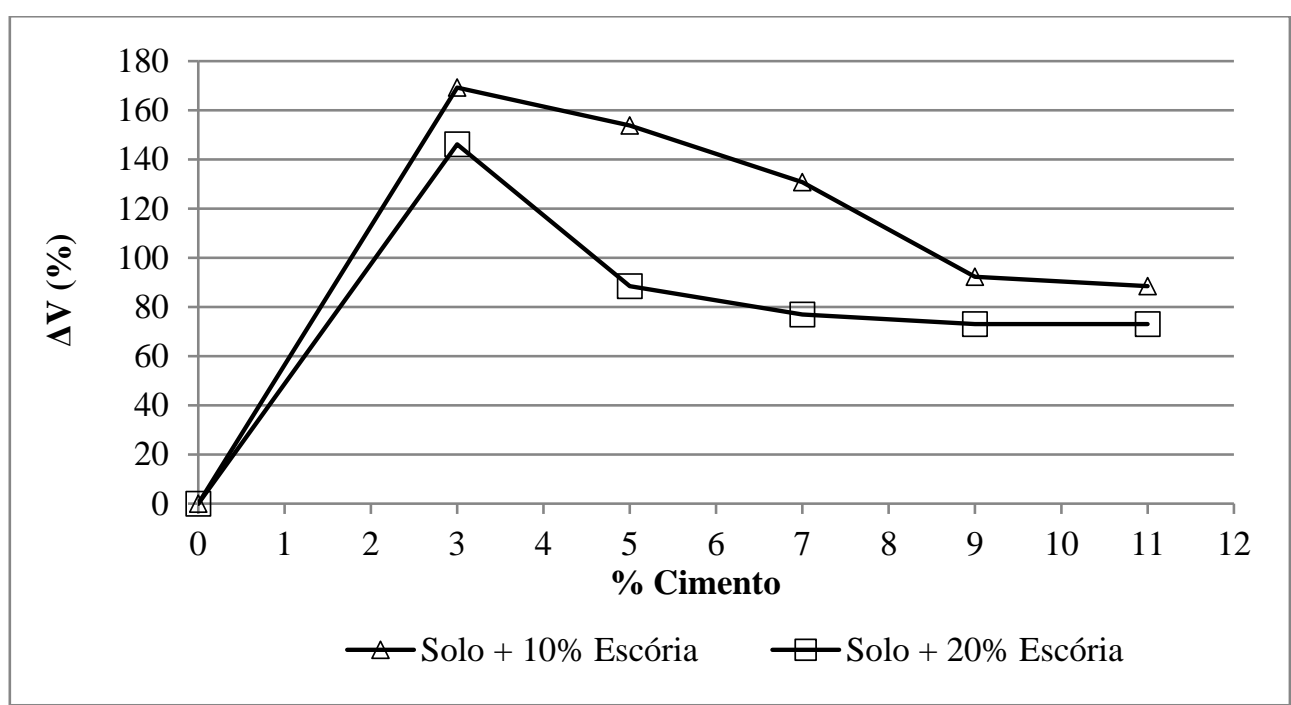

Figura 4.17 Dosagem físico-química do solo, 10 e 20\% de escória de cobre pós-jateada.

Na Figura 4.18 visualiza-se a diferença na variação volumétrica durante um momento da dosagem físico-química. A Figura 4.18a representa a proveta contendo $20,0 \mathrm{~g}$ de solo puro e $3 \%$ de cimento indicando uma leitura de $74 \mathrm{~cm}^{3}$. Já a Figura

4.18 b representa a proveta contendo a mistura de $20,0 \mathrm{~g}$ de solo mais $20 \%$ de escória de cobre e $3 \%$ de cimento indicando uma leitura de $64 \mathrm{~cm}^{3}$.

(a)

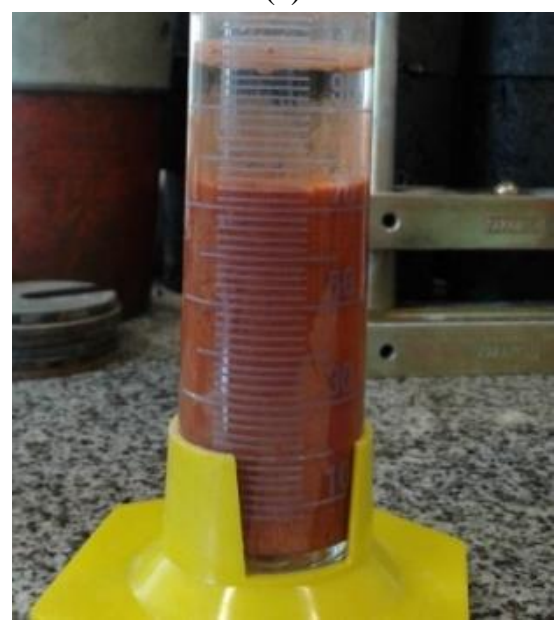

(b)

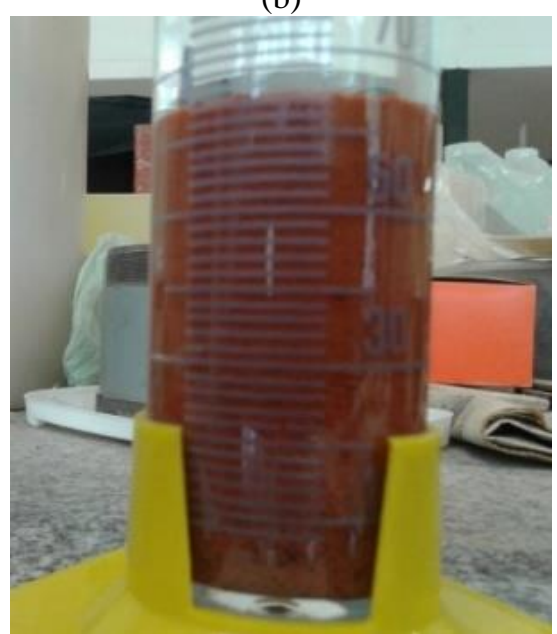

Figura 4.18 Dosagem físico-química: (a) solo puro + 3\% cimento Portland e (b) mistura de solo + $20 \%$ escória de cobre pós-jateada $+3 \%$ cimento Portland.

A suspensão aquosa, dada pela mistura de solo-cimento e água, forma um sistema polidisperso com partículas finas eletricamente carregadas tanto pelos argilominerais carregados negativamente, quanto pelos grãos do cimento Portland que apresentam como um todo cargas elétricas positivas, as quais interagem entre si e com o líquido (Ceratti, 1991; Casanova, 1992). 
A partir dessa interação uma observação feita durante o ensaio foi a formação de um sistema floculado, visível a olho nu, e uma queda do nível da interface sedimento/sobrenadante, também observado nos estudos realizados por Ceratti (1991), com a redução da coluna do sedimento e, consequentemente, redução do volume do sedimento na proveta, conforme visto na Figura 4.18. Porém, essa redução do volume variou com o teor de cimento em relação ao volume do solo puro (sem cimento) e também quando se adicionava a escória de cobre pós-jateada. Tomando-se como parâmetro a dosagem físico-química para as misturas contendo 10 e $20 \%$ de escória, foram realizados os ensaios de compressão simples do solo com diferentes teores de cimento e porcentagens de escória variando de 10 a $40 \%$. Todos os teores de cimento e de escória foram referentes à massa de solo seco. Os resultados estão mostrados na Tabela 4.23 .

Tabela 4.23 Resistência à compressão simples das misturas solo, escória de cobre pós-jateada e cimento Portland.

\begin{tabular}{|c|c|c|c|c|c|c|c|c|c|c|}
\hline $\begin{array}{c}\text { Escória } \\
\%\end{array}$ & $\begin{array}{c}\text { Cimento } \\
\%\end{array}$ & \multicolumn{3}{|c|}{$\begin{array}{l}\text { RCS } \\
(\mathrm{MPa})\end{array}$} & Média & $\begin{array}{l}\text { Desvio } \\
\text { Padrão }\end{array}$ & \multicolumn{3}{|c|}{$\begin{array}{c}\text { Umidade de } \\
\text { moldagem } \\
(\%)\end{array}$} & $\begin{array}{c}\text { Umidade } \\
\text { ótima } \\
(\%)\end{array}$ \\
\hline \multirow{5}{*}{10} & 0 & 0,90 & 0,85 & 0,76 & 0,84 & $\pm 0,04$ & 8,4 & 8,2 & 8,2 & 8,5 \\
\hline & 3 & 1,68 & 1,52 & 0,86 & 1,35 & $\pm 0,25$ & 8,5 & 8,4 & 8,1 & 8,5 \\
\hline & 5 & 2,10 & 2,25 & 1,95 & 2,10 & $\pm 0,09$ & 8,0 & 7,9 & 8,0 & 8,3 \\
\hline & 7 & 3,08 & 2,92 & 2,75 & 2,92 & $\pm 0,09$ & 8,7 & 8,6 & 8,8 & 8,3 \\
\hline & 9 & 3,75 & 4,18 & 3,82 & 3,92 & $\pm 0,13$ & 9,3 & 9,2 & 9,3 & 8,5 \\
\hline \multirow{3}{*}{20} & 0 & 0,87 & 0,78 & 1,02 & 0,89 & $\pm 0,07$ & 7,1 & 7,9 & 7,8 & 8,0 \\
\hline & 3 & 1,75 & 1,52 & 1,21 & 1,49 & $\pm 0,16$ & 7,7 & 7,7 & 7,4 & 7,5 \\
\hline & 5 & 2,52 & 2,58 & 2,23 & 2,44 & $\pm 0,11$ & 9,1 & 7,4 & 7,3 & 7,8 \\
\hline \multirow{3}{*}{30} & 0 & 0,92 & 0,91 & 1,01 & 0,95 & $\pm 0,03$ & 8,0 & 7,7 & 7,3 & 7,7 \\
\hline & 3 & 1,82 & 1,31 & 1,38 & 1,50 & $\pm 0,16$ & 7,5 & 7,0 & 7,3 & 7,3 \\
\hline & 5 & 3,34 & 2,51 & 2,93 & 2,93 & $\pm 0,24$ & 8,2 & 6,7 & 6,7 & 7,2 \\
\hline \multirow{3}{*}{40} & 0 & 0,88 & 0,97 & 0,70 & 0,85 & $\pm 0,08$ & 7,4 & 7,1 & 6,8 & 7,2 \\
\hline & 3 & 1,69 & 1,12 & 1,01 & 1,27 & $\pm 0,21$ & 7,7 & 7,4 & 7,6 & 7,5 \\
\hline & 5 & 3,16 & 2,55 & 2,17 & 2,63 & $\pm 0,29$ & 8,0 & 6,4 & 6,5 & 7,1 \\
\hline
\end{tabular}

Em geral, ao se adicionar cimento para uma mesma porcentagem de escória observa-se o aumento de resistência. Contudo, deve-se notar que com 5\% de cimento e $10 \%$ de escória já é possível obter uma resistência mínima de 2,1 MPa, sendo que para teores de 7 e $9 \%$ do aditivo, a resistência foi 39 e $87 \%$ superior à 
mínima (2,1 MPa), respectivamente. A Figura 4.19 mostra uma comparação entre a média dos valores de RCS para o solo-cimento e para a mistura com solo-cimento e $10 \%$ de escória, onde pode ser observado que, com essa adição de escória, foi possível reduzir o teor de cimento em pelos menos 3\% e ainda garantir a resistência mínima.

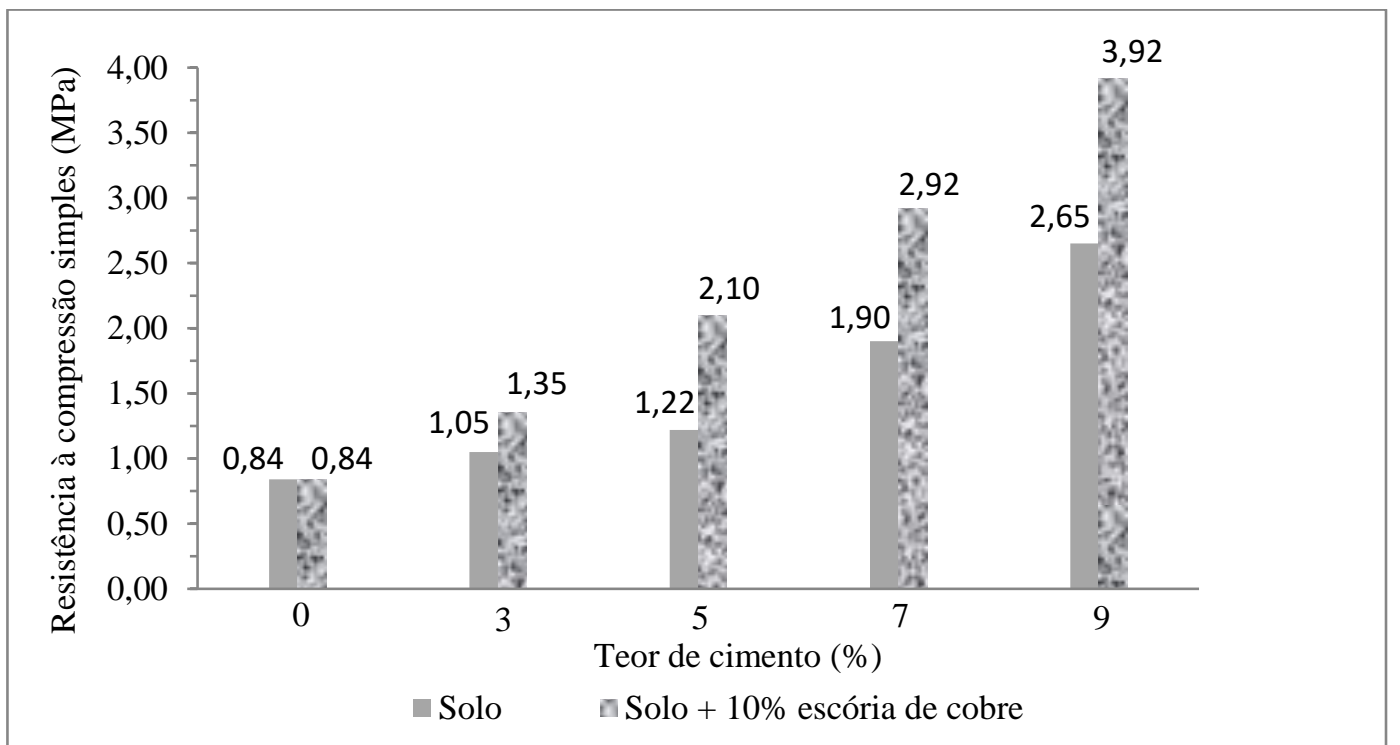

Figura 4.19 Resistência à compressão simples (MPa) versus teor de cimento Portland (\%) do solo e da mistura solo e $10 \%$ de escória de cobre pós-jateada.

Quando se adiciona a escória de cobre pode-se observar que:

$\checkmark \quad$ para $10 \%$ de escória, mantendo-se constante o teor de cimento, a resistência nem sempre é obtida para maiores umidades;

$\checkmark \quad$ para $20 \%$ de escória com $3 \%$ de cimento, as maiores resistências foram obtidas para umidades maiores que a ótima;

para 30 e $40 \%$ de escória, as maiores resistências foram alcançadas com maiores umidades.

Daí, pode-se induzir que a umidade de moldagem teve uma contribuição na resistência indicando que, assim como na mistura com solo-cimento, gerou uma estrutura diferenciada entre a floculada e a dispersa, como um dos fatores de influência. Vale destacar, como um fator influenciador da umidade sob a resistência, a superfície vítrea da escória de cobre. Se a água age como um lubrificante, as partículas de solo e escória, por intermédio da energia de compactação intermediária, tendem a deslizar umas sobre as outras, criando arranjo 
mais denso, compacto e intertravado, fazendo elevar a resistência com o aumento da porcentagem de escória de cobre.

A Figura 4.20 e 4.21 são apresentadas as curvas representativas de resistências para algumas amostras de cada mistura. Na Figura 4.20 é válido para misturas com 3\% de cimento e a Figura 4.21, para misturas com 5\% do aditivo. Observa-se que as amostras contendo escória com 3\% de cimento são pouco mais deformáveis do que as amostras com $5 \%$ de cimento, ambas com porcentagens de escória.

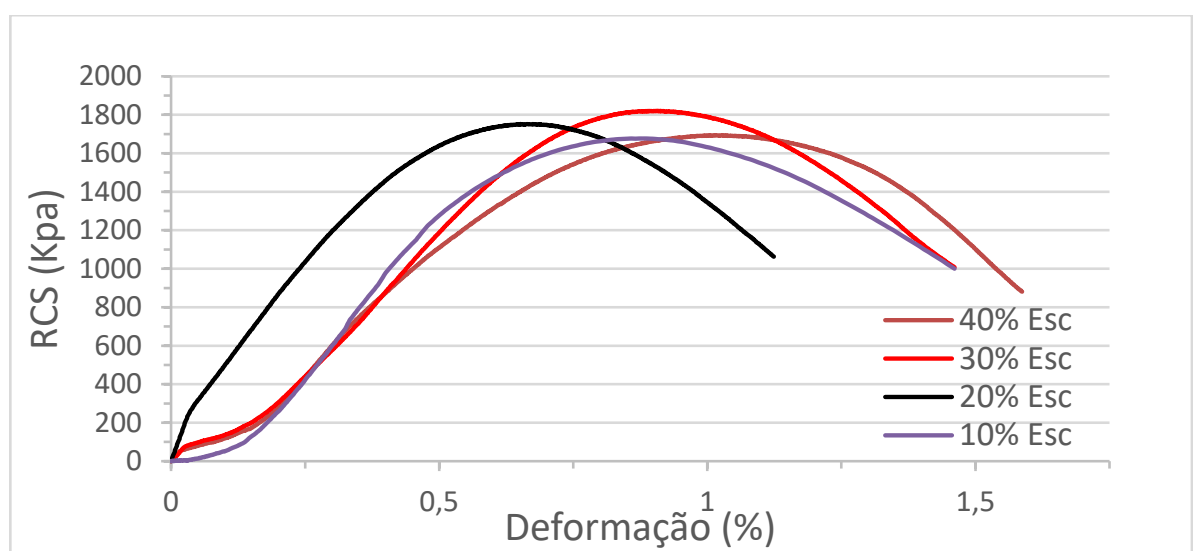

Figura 4.20 Curvas de RCS versus Deformação para misturas com 3\% de cimento Portland e porcentagens de escória de cobre pós-jateada.

Nota-se que as misturas com $3 \%$ de cimento apresentaram uma maior tenacidade caracterizado pelo pico de resistência, isso indicando que houve um maior acumulo de energia para romper. Comportamento diferente para as misturas com $5 \%$ de cimento, em que houve um aumento do pico de resistência tão logo o corpo de prova rompeu.

As curvas mostram que as deformações no pico de resistência para as misturas com 3\% de cimento foram ligeiramente maiores comparadas com as deformações para 5\% do aditivo, indicando uma maior rigidez dos corpos de prova. A Figura 4.22 mostra o plano de ruptura de corpos de provas com teor de $30 \%$ de escória e $5 \%$ de cimento após serem rompidos. 


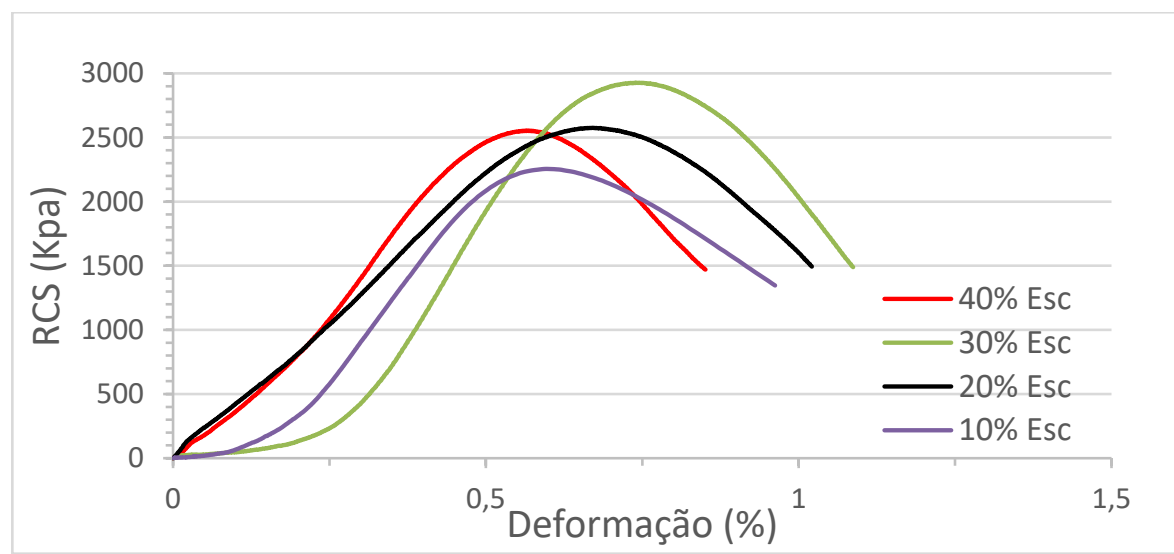

Figura 4.21 Curvas de RCS versus Deformação para as misturas com 5\% de cimento Portland e porcentagens de escória de cobre pós-jateada.

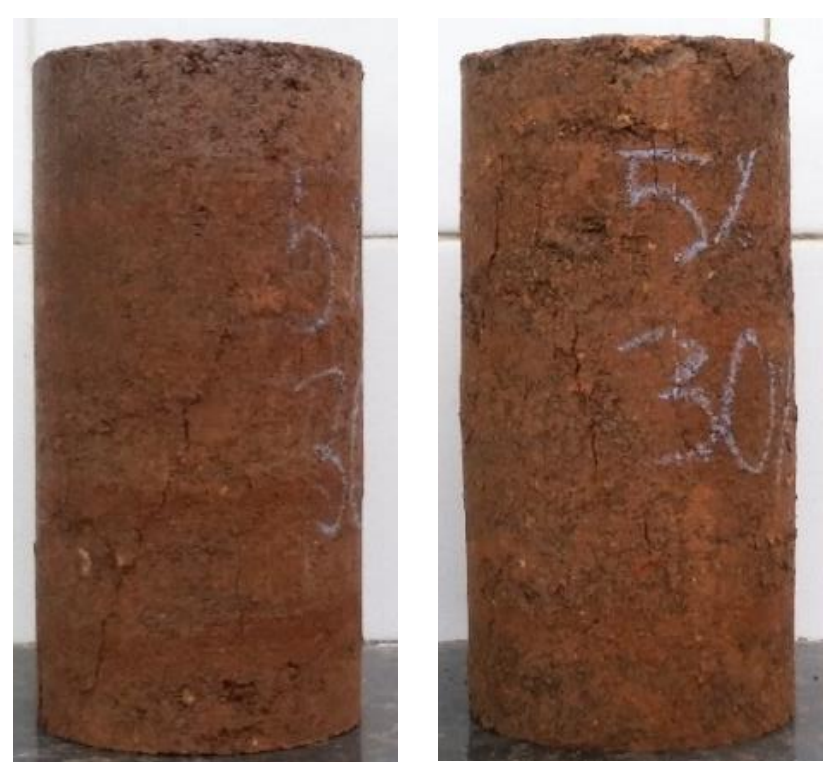

Figura 4.22 Ruptura de corpos de prova com 30\% de escória e 5\% cimento após rompimento à compressão simples.

A partir dos resultados da mistura com $10 \%$ de escória, as outras misturas se limitaram até 5\% de cimento, uma vez que ficou comprovado que esse teor do aditivo já seria suficiente para as outras porcentagens de escória. Observa-se que, ao aumentar a porcentagem de escória, para o mesmo teor de $5 \%$ de cimento, a resistência continua a aumentar até $30 \%$ de escória e começa a cair para $40 \%$ do resíduo.

O mesmo não aconteceu para 3\% de cimento, pois em nenhum dos ensaios, para esse teor de cimento, não foi possível chegar a uma resistência de 2,1 $\mathrm{MPa}$ e para $40 \%$ de escória a resistência diminui. A Figura 4.23 representa graficamente a média dos valores de resistência à compressão simples com 5\% de cimento para cada uma das porcentagens de escória. 


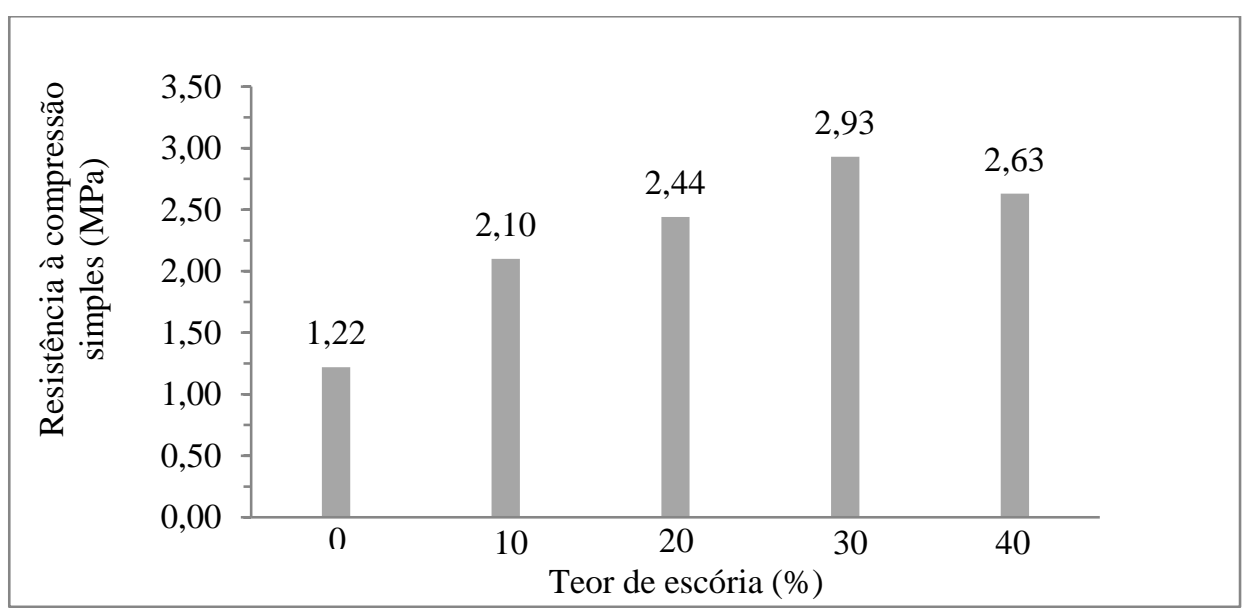

Figura 4.23 Resistência à compressão simples (MPa) versus teor de escória de cobre pós-jateada (\%) para $5 \%$ de cimento Portland.

Mas, por que houve redução da resistência para um teor de $40 \%$ de escória nos teores de 3 e $5 \%$ de cimento? Sabe-se que qualquer solo pode ser estabilizado com cimento, no entanto existem aqueles mais indicados para tal aditivo, como os solos arenosos de boa graduação e com plasticidade média a baixa. Nesse tipo de solo, as numerosas áreas de contato entre as partículas produzirão uma ação cimentante mais forte. Para as areias de graduação uniforme, que têm um número menor de áreas de contato entre os grãos, necessitam um maior de teor de cimento. Assim, pode-se entender que, para $40 \%$ de escória, as áreas de contato entre as partículas são menores, o que faz elevar o teor de cimento para elevar a resistência. Portanto, para o solo estudado, a porcentagem de escória de cobre pós-jateada e o teor de cimento Portland ideal são 30\% e 5\%, respectivamente. Esse resultado corrobora com aquele obtido ao se adicionar ao solo $30 \%$ de escória (Tabela 4.17).

Observa-se ainda da Tabela 4.23 que algumas resistências, para o mesmo teor de cimento, tiveram variações maiores de um ensaio para outro. Como visto na literatura, entre os fatores que podem afetar a resistência está a granulometria do solo. A Figura 4.24 mostra o corpo de prova do ensaio com $3 \%$ de cimento e $10 \%$ de escória, em que foi obtido uma resistência de 0,86 MPa e é possível observar o acumulo da fração mais grossa na base do corpo de prova que pode causar fragilidade, não correspondendo ao real valor de resistência. 


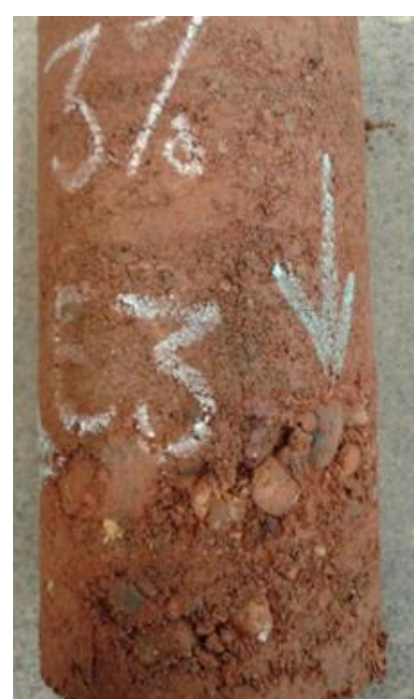

Figura 4.24 Corpo de prova do ensaio com 3\% de cimento Portland e 10\% de escória de cobre pósjateada.

Em comparação a dosagem físico-química, em que o teor de cimento seria $3 \%$, e a dosagem obtida pelos ensaios de resistência fica evidente que não foi possível chegar a uma resistência mínima para 3\% do aditivo ao se misturar com escória. No entanto, tanto para o solo, quanto para a mistura do solo com a escória, a dosagem físico-química serviu para indicar, pelo menos, um teor de cimento em que se pode iniciar o ensaio de resistência e gradativamente aumentar esse teor. Pode-se observar por essa dosagem físico-química que o teor indicado gera uma ação modificadora do solo, conforme observado na literatura: diminuição da plasticidade com aumento ou não da resistência.

Uma serie de análises de variâncias, com nível de confiabilidade de 95\%, foi realizada considerando os vários teores de cimento para o mesmo teor de escória, indicando haver diferenças significativas entre os tratamentos, isto é, a adição do cimento em diferentes porcentagens de escória produziu diferenças estatísticas de resistência à compressão. Um teste Tukey mostrou para quais misturas existem diferenças, conforme será analisada a seguir:

- ANOVA para $10 \%$ de escória variando o teor de cimento

O acréscimo de cimento até $9 \%$ ao teor de $10 \%$ de escória traz diferenças estatísticas entre as seguintes misturas (Figura 4.25):

$\checkmark 5 \%$ de cimento em relação ao solo puro e à mistura com $3 \%$ do aditivo;

$\checkmark 7 \%$ de cimento em relação ao solo puro e à mistura com 3 e $5 \%$ do aditivo;

$\checkmark 9 \%$ de cimento em relação às misturas anteriores. 
$10 \%$ Escória

Solo puro Solo c/ $3 \%$ cimento Solo c/5\% cimento Solo c $/ 7 \%$ cimento Solo $\mathrm{c} / 9 \%$ cimento

$\begin{array}{lllll}0,9 & 1,68 & 2,1 & 3,08 & 3,75 \\ 0,85 & 1,52 & 2,25 & 2,92 & 4,18 \\ 0,76 & 0,86 & 1,95 & 2,75 & 3,82\end{array}$

Anova: fator único

RESUMO

\begin{tabular}{llrrrr}
\multicolumn{1}{c}{ Grupo } & Contagem & Soma & Média & \multicolumn{1}{c}{ Variância } \\
\hline Solo puro & 3 & 2,51 & 0,84 & 0,0050 \\
Solo c/3\% cimento & 3 & 4,06 & 1,35 & 0,1889 \\
Solo c/5\% cimento & 3 & 6,30 & 2,10 & 0,0225 \\
Solo c/7\% cimento & 3 & 8,75 & 2,92 & 0,0272 \\
Solo c/9\% cimento & 3 & 11,75 & 3,92 & 0,0532 \\
\hline
\end{tabular}

ANOVA

\begin{tabular}{|c|c|c|c|c|c|c|}
\hline Fonte da variação & $S Q$ & $g l$ & $M Q$ & $F$ & valor-P & F critico \\
\hline Entre grupos & 18,12911 & 4 & 4,53228 & 76,31808 & $1,88 \mathrm{E}-07$ & 3,47805 \\
\hline Dentro dos grupos & 0,59387 & 10 & 0,05939 & & & \\
\hline
\end{tabular}

Total $18,72297 \quad 14$

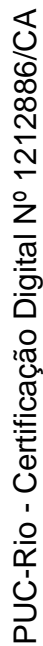

Figura 4.25 Análise de variância para 10\% de escória em relação à \% de cimento.

- ANOVA para $20 \%$ de escória variando o teor de cimento

As misturas com teores de 3 e $5 \%$ de cimento em $20 \%$ de escória produziu diferenças estatísticas entre o teor de $3 \%$ de cimento em relação ao solo puro e entre $5 \%$ de cimento em relação à mistura de $3 \%$ do aditivo e ao solo puro (Figura 4.26). 
$20 \%$ Escória

$\begin{array}{ccc}\text { Solo puro } & \text { Solo c/3\% cimento } & \text { Solo } / 5 \% \text { cimento } \\ 0,87 & 1,75 & 2,52 \\ 0,78 & 1,52 & 2,58 \\ 1,02 & 1,21 & 2,23\end{array}$

Anova: fator único

RESUMO

\begin{tabular}{|c|c|c|c|c|}
\hline Grupo & Contagem & Soma & Média & Variância \\
\hline Solo puro & 3 & 2,67 & 0,89 & 0,0147 \\
\hline Solo c/3\% cimento & 3 & 4,48 & 1,49 & 0,0734 \\
\hline Solo c/5\% cimento & 3 & 7,33 & 2,44 & 0,0350 \\
\hline
\end{tabular}

ANOVA

\begin{tabular}{|c|c|c|c|c|c|c|c|}
\hline Fonte da variação & $S Q$ & $g l$ & & $M Q$ & $F$ & valor-P & F crítico \\
\hline Entre grupos & 3,67936 & & 2 & 1,83968 & 44,80947 & 0,000247 & 5,14325 \\
\hline Dentro dos grupos & 0,24633 & & 6 & 0,04106 & & & \\
\hline Total & 3,92569 & & 8 & & & & \\
\hline
\end{tabular}

Figura 4.26 Análise de variância para $20 \%$ de escória em relação à \% de cimento.

- ANOVA para $30 \%$ de escória variando o teor de cimento

As misturas com teores de 3 e 5\% de cimento em $30 \%$ de escória produziu diferenças estatísticas entre o teor de $3 \%$ de cimento em relação ao solo puro e entre $5 \%$ de cimento em relação à mistura de $3 \%$ do aditivo e ao solo puro (Figura 4.27). 
$30 \%$ Escória

$\begin{array}{ccc}\text { Solo puro } & \text { Solo c/3\% cimento } & \text { Solo } / 5 \% \text { cimento } \\ 0,92 & 1,82 & 3,34 \\ 0,91 & 1,31 & 2,51 \\ 1,01 & 1,38 & 2,93\end{array}$

Anova: fator único

RESUMO

\begin{tabular}{|c|c|c|c|c|}
\hline Grupo & Contagem & Soma & Média & Variância \\
\hline Solo puro & 3 & 2,84 & 0,95 & 0,0030 \\
\hline Solo c/3\% cimento & 3 & 4,51 & 1,50 & 0,0764 \\
\hline Solo c/5\% cimento & 3 & 8,78 & 2,93 & 0,1722 \\
\hline
\end{tabular}

ANOVA

\begin{tabular}{|c|c|c|c|c|c|c|c|}
\hline Fonte da variação & $S Q$ & $g l$ & & $M Q$ & $F$ & valor-P & F crítico \\
\hline Entre grupos & 6,25616 & & 2 & 3,12808 & 37,28341 & 0,00041 & 5,14325 \\
\hline Dentro dos grupos & 0,50340 & & 6 & 0,08390 & & & \\
\hline Total & 6,75956 & & 8 & & & & \\
\hline
\end{tabular}

Figura 4.27 Análise de variância para $30 \%$ de escória em relação à \% de cimento.

- ANOVA para $40 \%$ de escória variando o teor de cimento

As misturas com teores de 3 e 5\% de cimento em $40 \%$ de escória produziu diferenças estatísticas entre o teor de $3 \%$ de cimento em relação ao solo puro e entre $5 \%$ de cimento em relação à mistura de $3 \%$ do aditivo e ao solo puro (Figura 4.28) 


$\begin{array}{ccc} & 40 \% \text { Escória } & \\ \text { Solo puro } & \text { Solo c/3\% cimento } & \text { Solo } / 5 \% \text { cimento } \\ 0,88 & 1,69 & 3,16 \\ 0,97 & 1,12 & 2,55 \\ 0,7 & 1,01 & 2,17\end{array}$

Anova: fator único

RESUMO

\begin{tabular}{|c|c|c|c|c|c|}
\hline Grupo & Contagem & Soma & & Média & Variância \\
\hline Solo puro & & 3 & 2,55 & 0,85 & 0,0189 \\
\hline Solo c/ $3 \%$ cimento & & 3 & 3,82 & 1,27 & 0,1332 \\
\hline Solo c/ $5 \%$ cimento & & 3 & 7,88 & 2,63 & 0,2494 \\
\hline
\end{tabular}

ANOVA

\begin{tabular}{|c|c|c|c|c|c|c|c|}
\hline Fonte da variação & $S Q$ & $g l$ & & $M Q$ & $F$ & valor- $P$ & F crítico \\
\hline Entre grupos & 5,16727 & & 2 & 2,58363 & 19,30165 & 0,00243 & 5,14325 \\
\hline Dentro dos grupos & 0,80313 & & 6 & 0,13386 & & & \\
\hline Total & 5,97040 & & 8 & & & & \\
\hline
\end{tabular}

Figura 4.28 Análise de variância para 40\% de escória em relação à \% de cimento.

Análises de variância considerando as várias porcentagens de escória para um mesmo teor de cimento, com nível de confiabilidade de 95\%, indicaram não haver diferenças significativas em todos os tratamentos, conforme análise a seguir.

- ANOVA para 3\% de cimento variando a porcentagem de escória

As misturas com 3\% de cimento e variando a porcentagem de escória até $40 \%$ não produziu diferenças estatísticas, isto é, o acréscimo de escória em $3 \%$ de cimento não traz influência significativa na resistência à compressão (Figura 4.29). 
$3 \%$ Cimento

Solo puro Solo c/10\% escória Solo c/20\% escória Solo c/30\% escória Solo c/40\% escória

$\begin{array}{lllll}1,07 & 1,68 & 1,75 & 1,82 & 1,69 \\ 1,08 & 1,52 & 1,52 & 1,31 & 1,12 \\ 1,00 & 0,86 & 1,21 & 1,38 & 1,01\end{array}$

Anova: fator único

RESUMO

\begin{tabular}{llrrrr}
\hline \multicolumn{1}{c}{ Grupo } & Contagem & Soma & Média & Variância \\
\hline Solo puro & 3 & 3,15 & 1,05 & 0,0019 \\
Solo c/10\% escória & 3 & 4,06 & 1,35 & 0,1889 \\
Solo c/20\% escória & 3 & 4,48 & 1,49 & 0,0734 \\
Solo c/30\% escória & 3 & 4,51 & 1,50 & 0,0764 \\
Solo c/40\% escória & 3 & 3,82 & 1,27 & 0,1332 \\
\hline
\end{tabular}

ANOVA

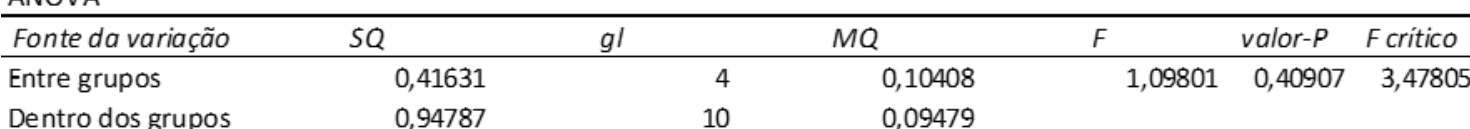

Total

1,36417

14

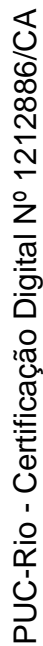

Figura 4.29 Análise de variância para 3\% de cimento em relação à \% de escória.

- ANOVA para 5\% de cimento variando a porcentagem de escória

As misturas com 5\% de cimento e variando a porcentagem de escória até $40 \%$ produziu diferenças estatísticas a partir de $10 \%$ de escória, isto é, a diferença ocorreu entre as porcentagens de escória em relação ao solo puro e não há diferenças entre as porcentagens de escória (Figura 4.30). 


$\begin{array}{ccccc}\text { 5\% Cimento } & & \\ \text { Solo Puro } & \text { Solo c/ } 10 \% \text { escória } & \text { Solo } / 20 \% \text { escória } & \text { Solo c/30\% escória } & \text { Solo c/40\% escória } \\ 1,31 & 2,1 & 2,52 & 3,34 & 3,16 \\ 1,19 & 2,25 & 2,58 & 2,51 & 2,55 \\ 1,15 & 1,95 & 2,23 & 2,93 & 2,17\end{array}$

Anova: fator único

RESUMO

\begin{tabular}{llrrrr}
\multicolumn{1}{c}{ Grupo } & Contagem & Soma & Média & \multicolumn{1}{c}{ Variância } \\
\hline Solo Puro & 3 & 3,65 & 1,22 & 0,0069 \\
Solo c/10\% escória & 3 & 6,30 & 2,10 & 0,0225 \\
Solo c/20\% escória & 3 & 7,33 & 2,44 & 0,0350 \\
Solo c/30\% escória & 3 & 8,78 & 2,93 & 0,1722 \\
Solo c/40\% escória & 3 & 7,88 & 2,63 & 0,2494 \\
\hline
\end{tabular}

ANOVA

\begin{tabular}{|c|c|c|c|c|c|c|}
\hline Fonte da variação & $S Q$ & $g l$ & $M Q$ & $F$ & valor-P & F critico \\
\hline Entre grupos & 5,17983 & 4 & 1,29496 & 13,31895 & 0,000514 & 3,47805 \\
\hline Dentro dos grupos & 0,97227 & 10 & 0,09723 & & & \\
\hline
\end{tabular}

Total

6,15209

14

Figura 4.30 Análise de variância para 5\% de cimento em relação à \% de escória.

Os limites de Atterberg das misturas após romper os corpos de prova revelaram que somente a amostra com $10 \%$ de escória de cobre pós-jateada e $3 \%$ de cimento foi possível obter o limite de liquidez de $26 \%$ e limite de plasticidade de $21 \%$ com índice de plasticidade de 5\%. Para as outras misturas, não foi possível obter os limites, sendo então não-plásticas. Ao comparar os valores dos limites entre as misturas solo-escória (Tabela 4.18), solo-cimento (Tabela 4.21) e solo-escóriacimento, pode-se inferir que a ação do cimento Portland no sentido de "quebrar" a plasticidade é maior em relação à escória, visto que para teores acima de $3 \%$ de cimento e $10 \%$ de escória a mistura passa a ser não-plástica. Dessa forma, a incorporação da escória à mistura de solo-cimento tem um efeito positivo no sentido de reduzir a plasticidade do solo.

Considerando a melhor mistura de solo com $30 \%$ de escória de cobre pósjateada e $5 \%$ de cimento Portland foi realizado o ensaio de permeabilidade acusando um valor do coeficiente de $1,8 \times 10^{-6} \mathrm{~cm} / \mathrm{s}$, que comparado ao do solo puro $(\mathrm{k}=1,4$ x $\left.10^{-4} \mathrm{~cm} / \mathrm{s}\right)$ e com a da mistura solo e $30 \%$ de escória $\left(\mathrm{k}=7,0 \times 10^{-5} \mathrm{~cm} / \mathrm{s}\right)$, houve uma redução ainda maior da permeabilidade. A Figura 4.31 mostra as imagens obtidas por microscopia eletrônica de varredura para essa mistura. Pode-se observar 
na Figura 4.31a uma superfície mais compacta com pouca presença de canalículos, com uma aproximação desses pequenos canais na Figura 4.31b.

(a)

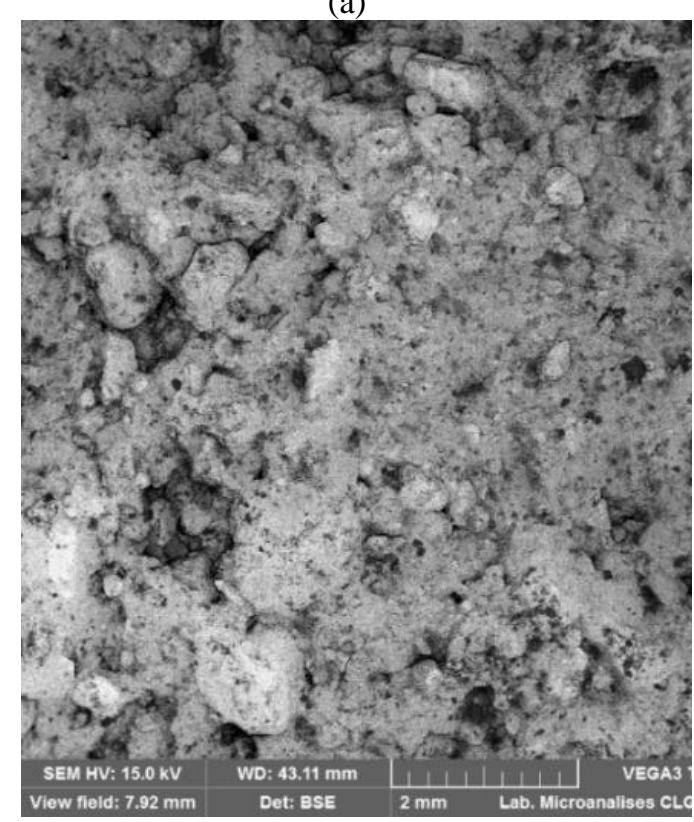

(b)

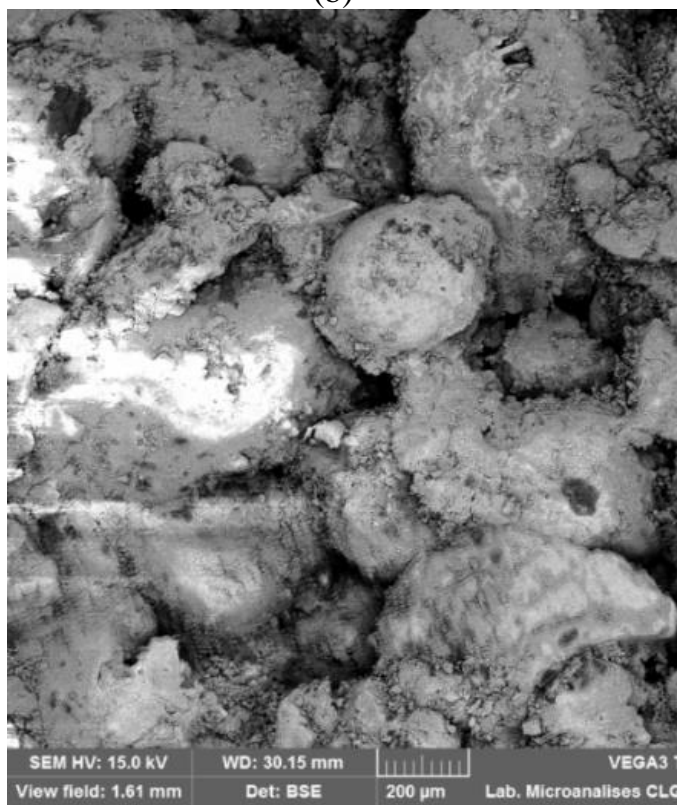

Figura 4.31 Microscopia eletrônica de varredura da mistura solo, 30\% de escória de cobre pósjateada e 5\% de cimento Portland.

Seguindo a mesma ideia matriz-esqueleto proposto por Herzog (1967), sumarizado por Rodrigues (1992), conforme apresentado no Capítulo da Revisão Bibliográfica desta tese, é possível descrever a razão para a redução da permeabilidade: com a hidratação do cimento, forma-se uma estrutura unida e interligada, fechando os poros, isto é, na estabilização com cimento se desenvolvem reações químicas do aditivo que criam vínculos entre a superfície dos grãos de cimento, as partículas de solo e os grãos da escória. Porém, a solidarização desse contato não é o mesmo que ocorre no concreto, conforme descreve Belincanta et al. (2006). A presença de $30 \%$ de escória de cobre pós-jateada contribuiu para o fechamento dos canalículos, conforme pode ser visto no resultado dos ensaios de permeabilidade com esse percentual de escória.

A Figura 4.32 mostra a microscopia realizada com a mistura de solo, $30 \%$ de escória e 3\% de cimento, a qual foi possível capturar uma imagem que complementa a descrição acima. Da Figura 4.32a pode-se observar os contornos dos grãos da escória de cobre com sua superfície esférica, mergulhados em uma matriz formada pelas partículas de solo, da própria escória e de cimento que, após as reações de 
hidratação, forma uma estrutura unida e interligada, que fecha os poros. A Figura 4.32b mostra uma ampliação dessa estrutura, que se mostra bem compacta.

(a)

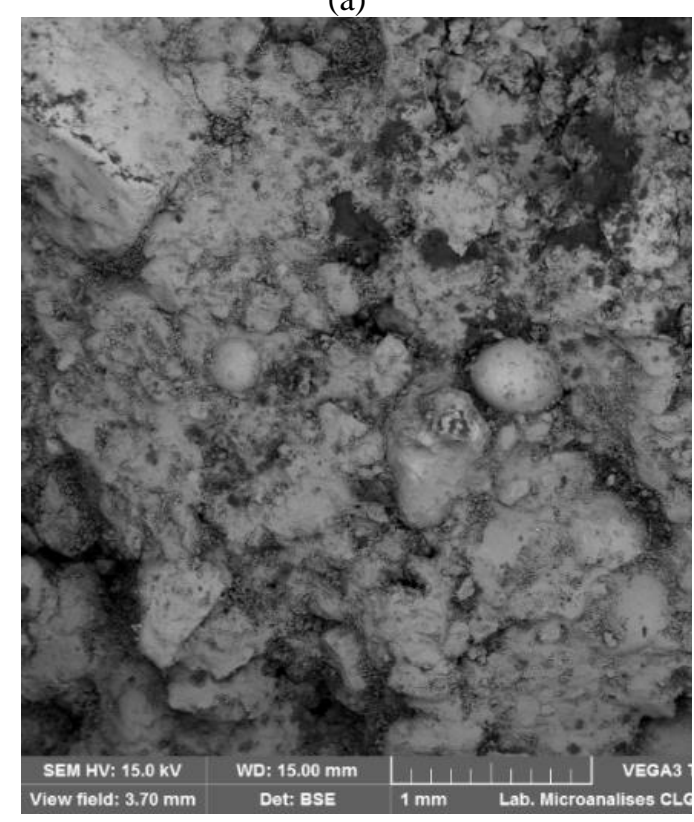

(b)

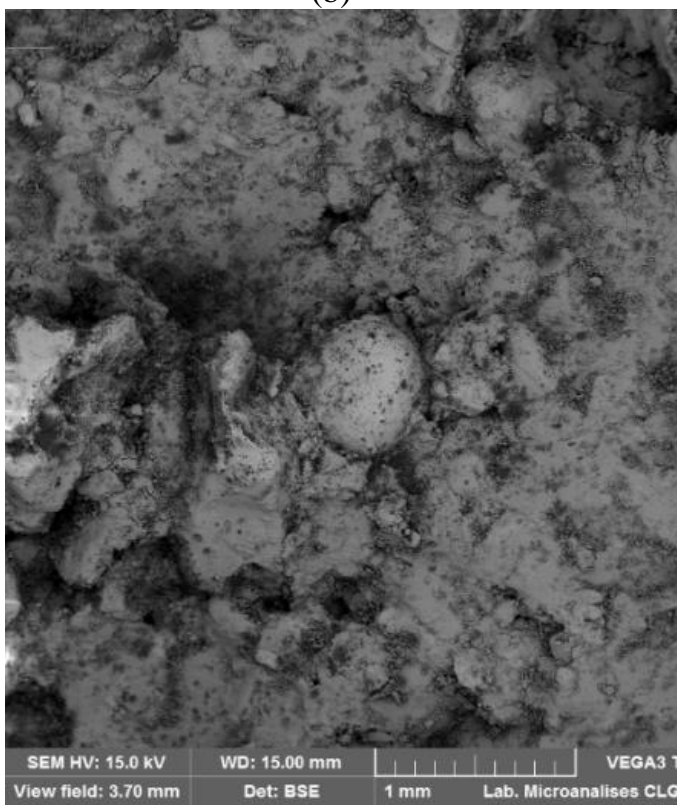

Figura 4.32 Microscopia eletrônica de varredura da mistura solo, 30\% de escória de cobre pósjateada e 3\% de cimento Portland.

Uma comparação entre as Figuras 4.31 e 4.32, observa-se que a mistura com $5 \%$ de cimento apresenta-se mais unida e interligada e isso está relacionada à maior porcentagem de cimento presente.

A perda de massa através do ensaio de durabilidade foi avaliada para as misturas com solo, $30 \%$ de escória de cobre pós-jateada e 5\% de cimento e os resultados revelaram uma perda de $1,43 \%, 1,46 \%$ e 2,00\%. No entanto, no ensaio da mistura de solo com $5 \%$ de cimento a perda de massa foi menor, obtendo-se os valores de 1,25\%, 1,33 e 1,59\%, indicando uma baixa perda de massa mesmo adicionando a escória à mistura. Apesar da pequena diferença, esperava-se que o corpo de prova contendo escória desprendessem menor quantidade de material durante as escovadelas, uma vez que a união que o cimento proporciona à matriz argilosa e os grãos da escória fosse capaz de segurar as partículas do solo e os grãos da escória. Assim, observa-se que a incorporação da escória à mistura de solocimento não causa maiores alterações na perda de massa. A Figura 4.33 mostra os corpos de prova após o ensaio para ambas as misturas. 
(a)

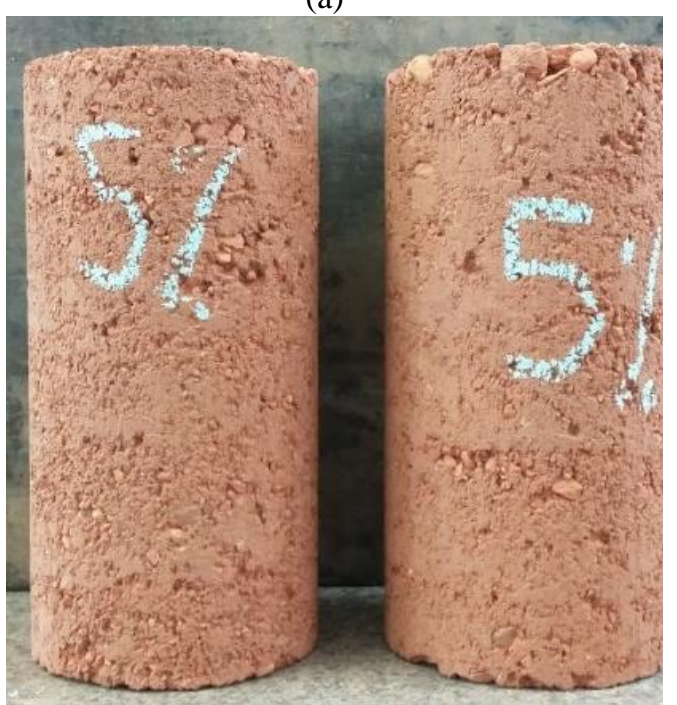

(b)

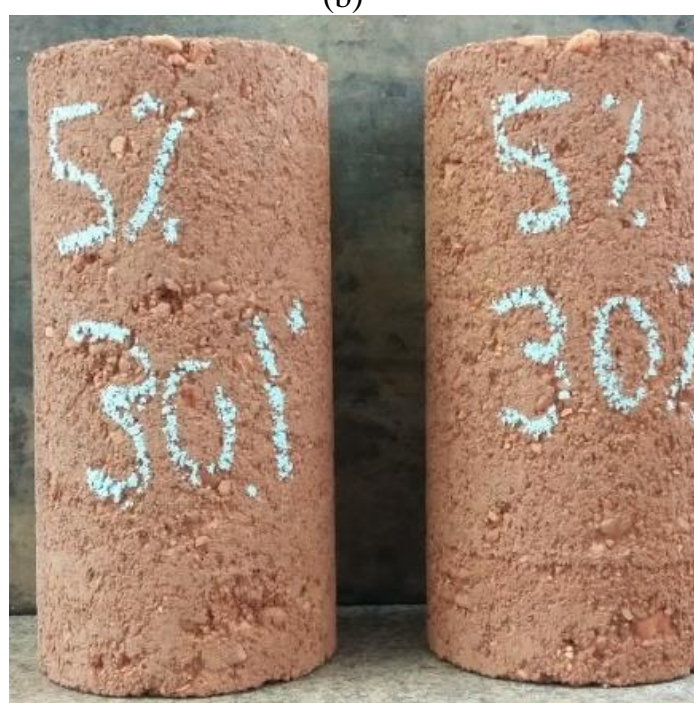

Figura 4.33 Corpos de prova após o ensaio de durabilidade: (a) solo e 5\% de cimento Portland e (b) solo, $30 \%$ escória de cobre pós-jateada e 5\% de cimento Portland.

Seguindo-se os procedimentos estabelecidos nas normas, o extrato lixiviado da mistura de solo com $30 \%$ de escória de cobre pós-jateada e 5\% de cimento Portland apresentou os resultados mostrados na Tabela 4.24, acusando estar abaixo que os limites máximos descritos no Anexo F da norma NBR 10004, não sofrendo alteração na classificação do resíduo.

Tabela 4.24 Resultado do ensaio de lixiviação da mistura solo, 30\% escória de cobre pós-jateada e 5\% cimento Portland - comparação com a listagem apresentada no anexo F da NBR 10004/2004.

\begin{tabular}{l|c|c|c}
\hline \multirow{2}{*}{ Parâmetro } & $\begin{array}{c}\text { Limite de quantificação } \\
(\mathrm{mg} / \mathrm{L})\end{array}$ & $\begin{array}{c}\text { Resultado } \\
(\mathrm{mg} / \mathrm{L})\end{array}$ & $\begin{array}{c}\text { Limite máximo no lixiviado } \\
(\mathrm{mg} / \mathrm{L})-\text { Anexo F }\end{array}$ \\
\hline Arsênio & 0,011 & 0,07 & 1,0 \\
Cádmio total & 0,001 & $<0,001$ & 0,5 \\
Chumbo total & 0,006 & 0,22 & 1,0 \\
Cromo total & 0,003 & 0,13 & 5,0 \\
Fluoretos total & 0,01 & 0,65 & 150 \\
Mercúrio & 0,001 & $<0,001$ & 0,1 \\
Prata total & 0,030 & $<0,030$ & 5,0 \\
Selênio & 0,01 & 0,04 & 1,0 \\
Cloretos & 2,42 & $<2,42$ & - \\
\hline
\end{tabular}

Os ensaios triaxiais de carga repetida foram realizados para se avaliar o comportamento da mistura solo, 30\% de escória de cobre pós-jateada e 5\% de cimento Portland com base na análise dos valores do módulo de resiliência (MR). $\mathrm{Na}$ Tabela 4.25 está apresentada os resultados das constantes de regressão do modelo. Analisando os coeficientes, verifica-se que o modelo dependente da tensão confinante $\left(\sigma_{3}\right)$ não se adequa à essa mistura. Por outro lado, os modelos 
dependentes da tensão desvio $\left(\sigma_{\mathrm{d}}\right)$ e o composto apresentaram os melhores comportamentos, condizendo com estudos realizados por Macêdo (1996), porém, o modelo composto se adequa melhor à mistura. No entanto, devido à proximidade nos valores dos coeficientes de determinação, infere-se que há uma maior dependência da parcela da tensão desvio do que a confinante.

Tabela 4.25 Parâmetros de resistência e coeficiente de determinação obtidos a partir dos modelos para os ensaios de MR, da mistura solo, $30 \%$ de escória de cobre pós-jateada e $5 \%$ de cimento Portland.

\begin{tabular}{l|cccc}
\hline \multicolumn{1}{c|}{ Modelo } & \multicolumn{5}{|c}{ Parâmetros } \\
& $\mathrm{K}_{1}$ & $\mathrm{~K}_{2}$ & $\mathrm{~K}_{3}$ & $\mathrm{R}^{2}$ \\
\hline $\mathrm{MR}=\mathrm{k}_{1 .} \sigma_{3}{ }^{\mathrm{k}}{ }_{2}$ & 30539 & 0,9387 & - & 0,6305 \\
$\mathrm{MR}=\mathrm{k}_{1} . \sigma_{\mathrm{d}^{\mathrm{k}}}{ }_{2}$ & 18335 & 0,9618 & - & 0,9954 \\
$\mathrm{MR}=\mathrm{k}_{1} \cdot \sigma_{3}{ }^{\mathrm{k}}{ }_{2} \cdot \sigma_{\mathrm{d}}{ }_{3}{ }_{3}$ & 16160 & $-0,0529$ & 0,9623 & 0,9961 \\
\hline
\end{tabular}

A média dos resultados dos parâmetros de resiliência e o coeficiente de determinação também foram obtidos a partir dos corpos de prova após o ensaio de durabilidade da mistura de solo, 30\% de escória e 5\% de cimento e está apresentada na Tabela 4.26. Observa-se dos resultados um comportamento semelhante à mesma mistura antes do ensaio de durabilidade (Tabela 4.25), ou seja, tanto o modelo dependente da tensão desvio quanto o composto se adequaram à mistura após o corpo de prova passar pelas escovadelas do ensaio de durabilidade. Porém, o primeiro modelo ficou mais bem representado à mistura, indicando a dependência da parcela da tensão desvio.

Tabela 4.26 Parâmetros de resistência e coeficiente de determinação obtidos a partir dos modelos para os ensaios de MR, da mistura solo, $30 \%$ de escória de cobre pós-jateada e $5 \%$ de cimento Portland de corpos de prova após ensaio de durabilidade.

\begin{tabular}{l|cccc}
\multicolumn{1}{c|}{ Modelo } & \multicolumn{5}{c}{ Parâmetros } \\
& $\mathrm{K}_{1}$ & $\mathrm{~K}_{2}$ & $\mathrm{~K}_{3}$ & $\mathrm{R}^{2}$ \\
\hline $\mathrm{MR}=\mathrm{k}_{1 .} \sigma_{3}{ }^{\mathrm{k}}{ }_{2}$ & 25184 & 1,0964 & - & 0,6639 \\
$\mathrm{MR}=\mathrm{k}_{1} . \sigma^{\mathrm{k}}{ }_{2}$ & 12884 & 1,0907 & - & 0,9878 \\
$\mathrm{MR}=\mathrm{k}_{1} . \sigma_{3}{ }^{\mathrm{k}}{ }_{2} \cdot \sigma_{\mathrm{d}} \mathrm{k}_{3}$ & 15150 & 0,0207 & 1,150 & 0,9825 \\
\hline
\end{tabular}

Os mesmos parâmetros de resiliência foram obtidos com uma mistura do solo e 5\% de cimento e a média dos resultados está apresentada na Tabela 4.27. Para essa mistura, os resultados mostram que há também a dependência da tensão desvio, semelhante à mistura anterior após o ensaio de durabilidade. 
Comparando-se os resultados desses parâmetros e dos coeficientes de determinação entre as misturas acima e o solo puro (Tabela 4.5), observa-se que o modelo dependente da parcela da tensão desvio tem uma maior contribuição, além de que o material cimentado tende a depender dessa tensão.

Tabela 4.27 Parâmetros de resistência e coeficiente de determinação obtidos a partir dos modelos para os ensaios de MR, da mistura solo e $5 \%$ de cimento Portland.

\begin{tabular}{|c|c|c|c|c|}
\hline \multirow{2}{*}{ Modelo } & \multicolumn{4}{|c|}{ Parâmetros } \\
\hline & $\mathrm{K}_{1}$ & $\mathrm{~K}_{2}$ & $\mathrm{~K}_{3}$ & $\mathrm{R}^{2}$ \\
\hline$\overline{\mathrm{MR}}=\mathrm{k}_{1 .} \sigma_{3} \mathrm{k}_{2}$ & 26447 & 0,9133 & - & 0,6616 \\
\hline $\mathrm{MR}=\mathrm{k}_{1 .} \sigma \mathrm{d}_{2}^{\mathrm{k}}$ & 15245 & 0,9118 & - & 0,9914 \\
\hline $\mathrm{MR}=\mathrm{k}_{1} \cdot \sigma_{3}{ }_{2}{ }_{2} \cdot \sigma_{\mathrm{d}}{ }^{\mathrm{k}}$ & 15170 & 0,0529 & 0,8323 & 0,9837 \\
\hline
\end{tabular}

As Figuras 4.34 a 4.36 estão apresentadas as superfícies no espaço tridimensional $\left(\sigma_{3}, \sigma_{\mathrm{d}} \times \mathrm{MR}\right)$ para as tensões aplicadas que foram geradas por ajustes, baseadas no modelo composto. A Figura 4.37 representa graficamente as tendências das curvas para esse modelo em função da tensão desvio para as misturas e o solo puro.

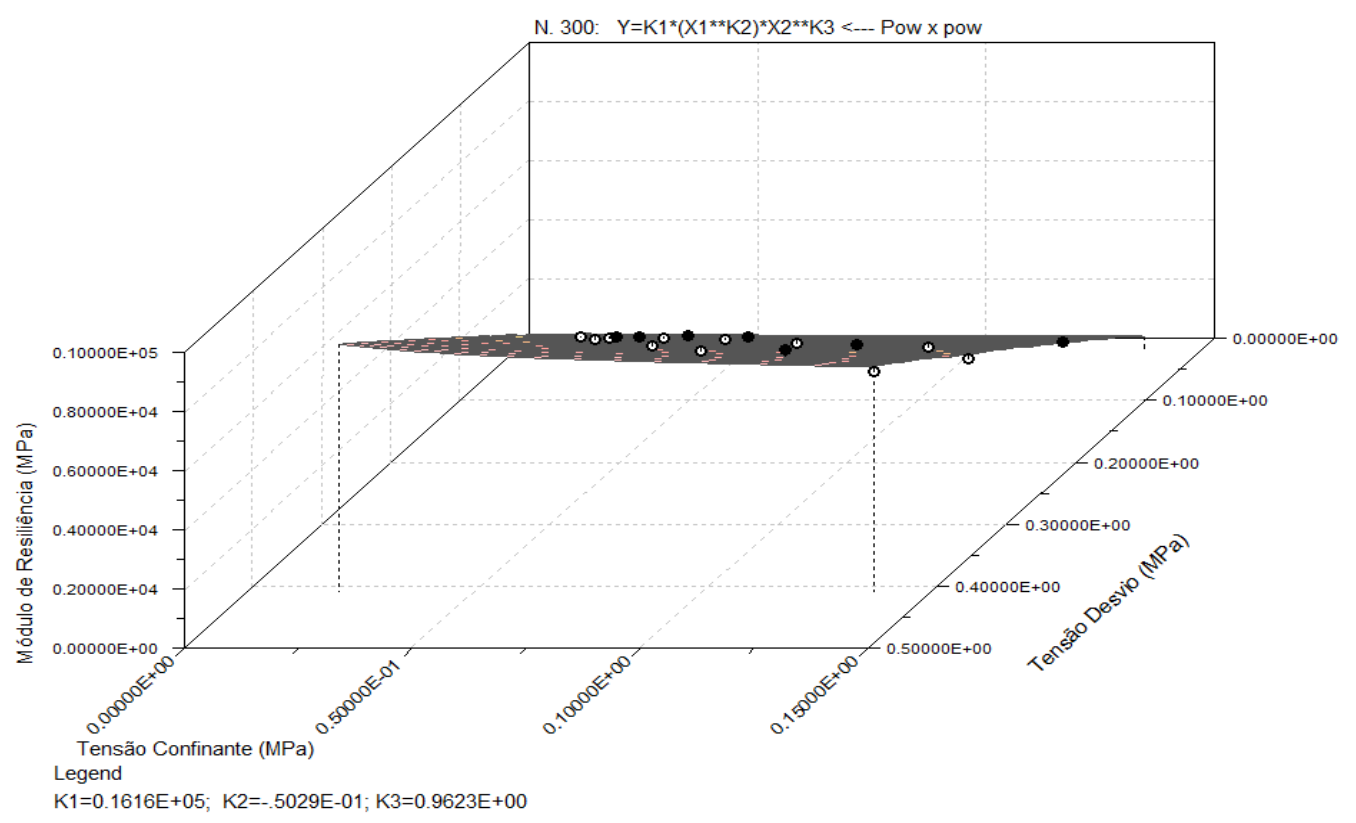

Figura 4.34 Gráfico 3D do modelo composto do módulo de resiliência da mistura solo, 30\% de escória e $5 \%$ de cimento. 


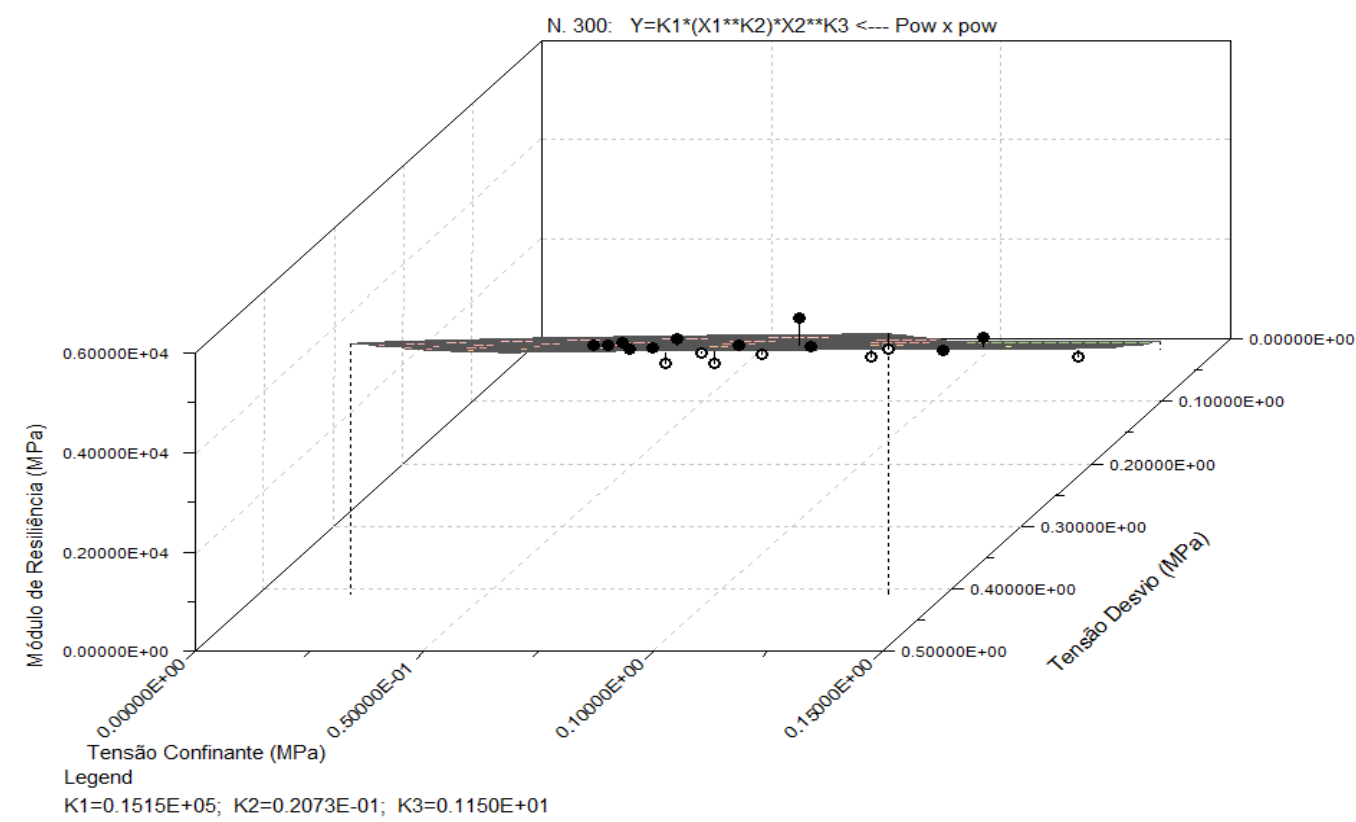

Figura 4.35 Gráfico 3D do modelo composto do módulo de resiliência da mistura solo, 30\% de escória e $5 \%$ de cimento após o ensaio de durabilidade.

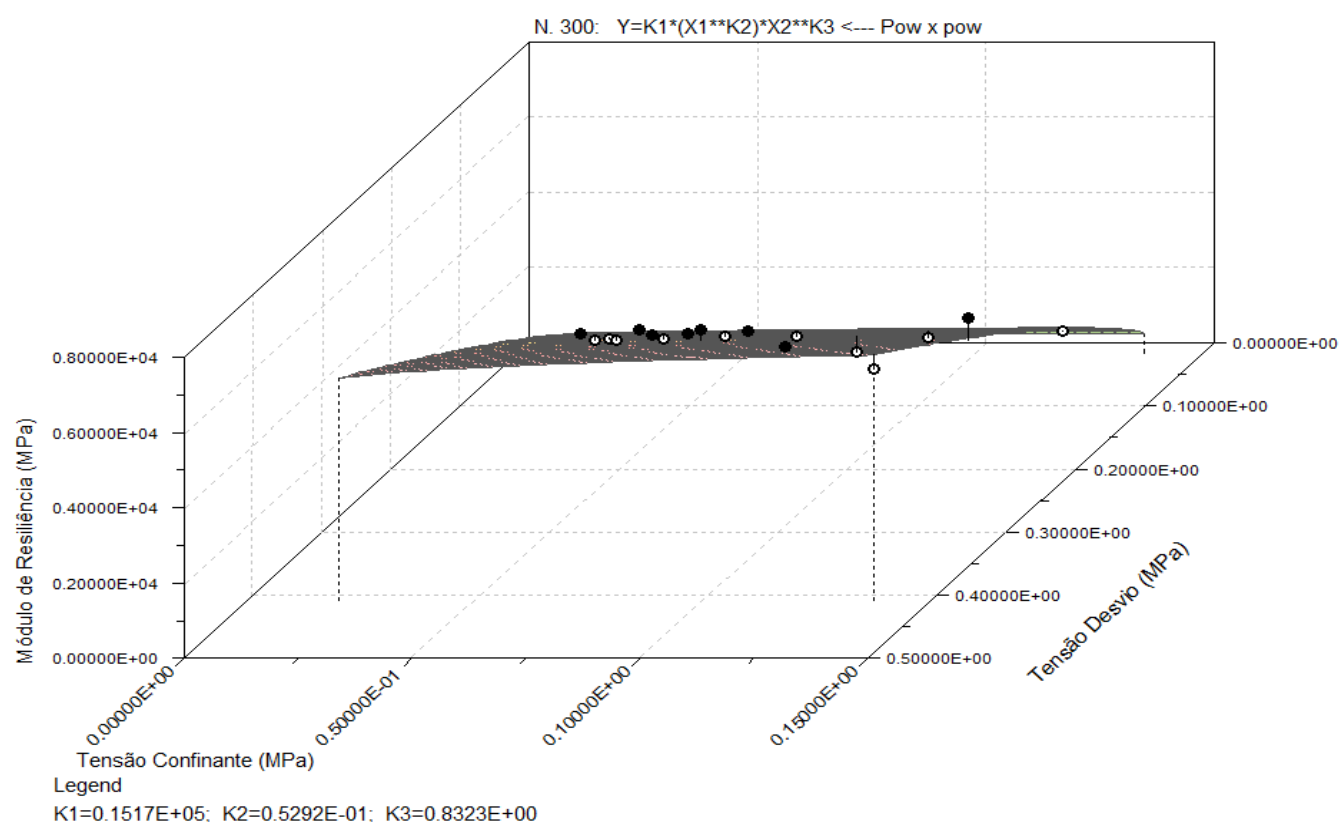

Figura 4.36 Gráfico 3D do modelo composto do módulo de resiliência da mistura solo e 5\% de cimento.

A Figura 4.38 indica em escala logarítmica os valores do módulo de resiliência em função da tensão desvio. Pode-se observar na figura que o solo puro apresenta módulos pouco acima de $1000 \mathrm{MPa}$, bem inferior à mistura com 30\% de escória e 5\% de cimento, a qual houve um aumento chegando a apresentar módulos próximos a $8000 \mathrm{MPa}$, quase coincidentes à mistura de solo e $5 \%$ de cimento. Após 
o ensaio de durabilidade, as amostras apresentaram tendência de redução do módulo, porém, ainda apresentam módulos na ordem de $5000 \mathrm{MPa}$.

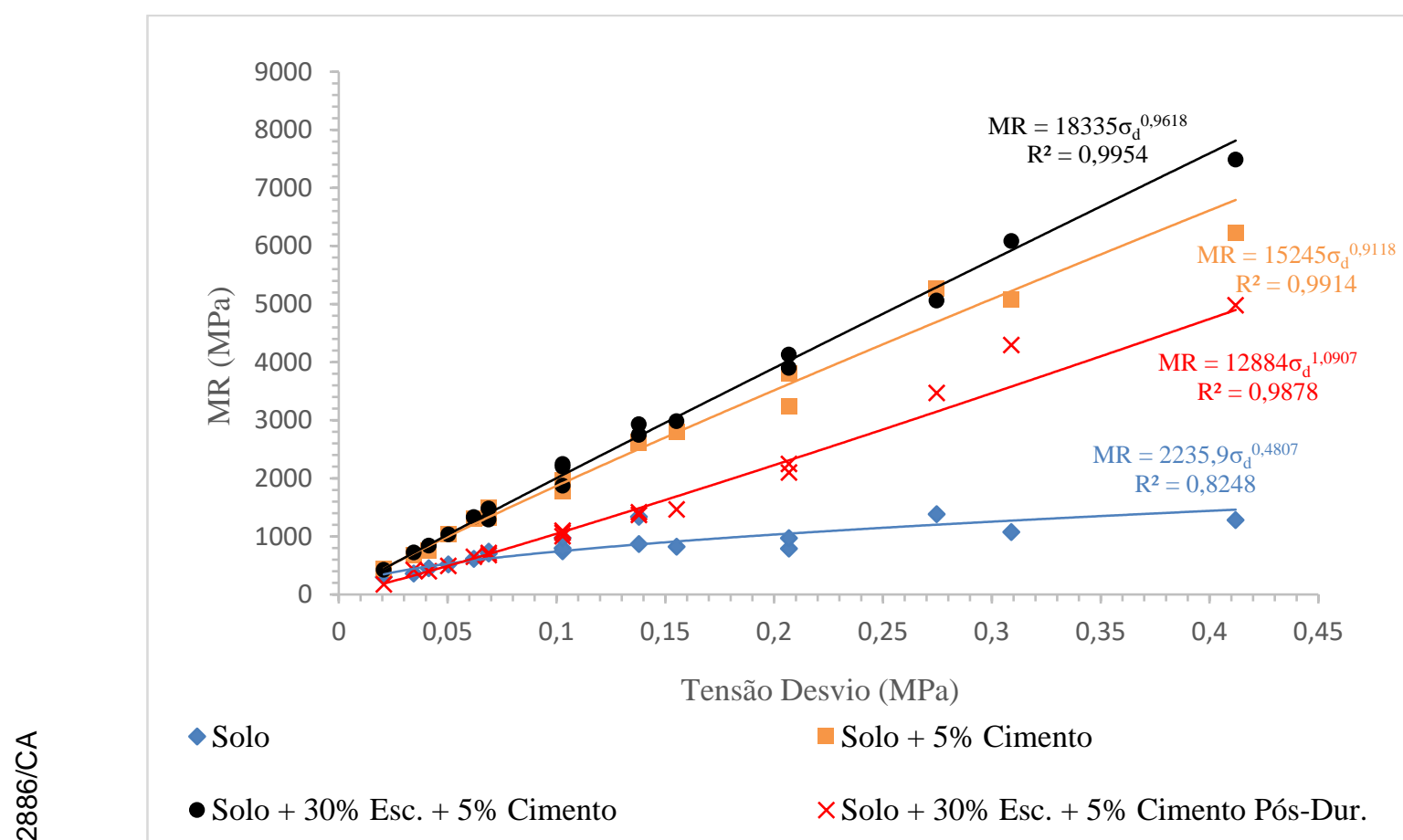

Figura 4.37 Módulo de resiliência versus tensão desvio para as misturas e o solo puro.

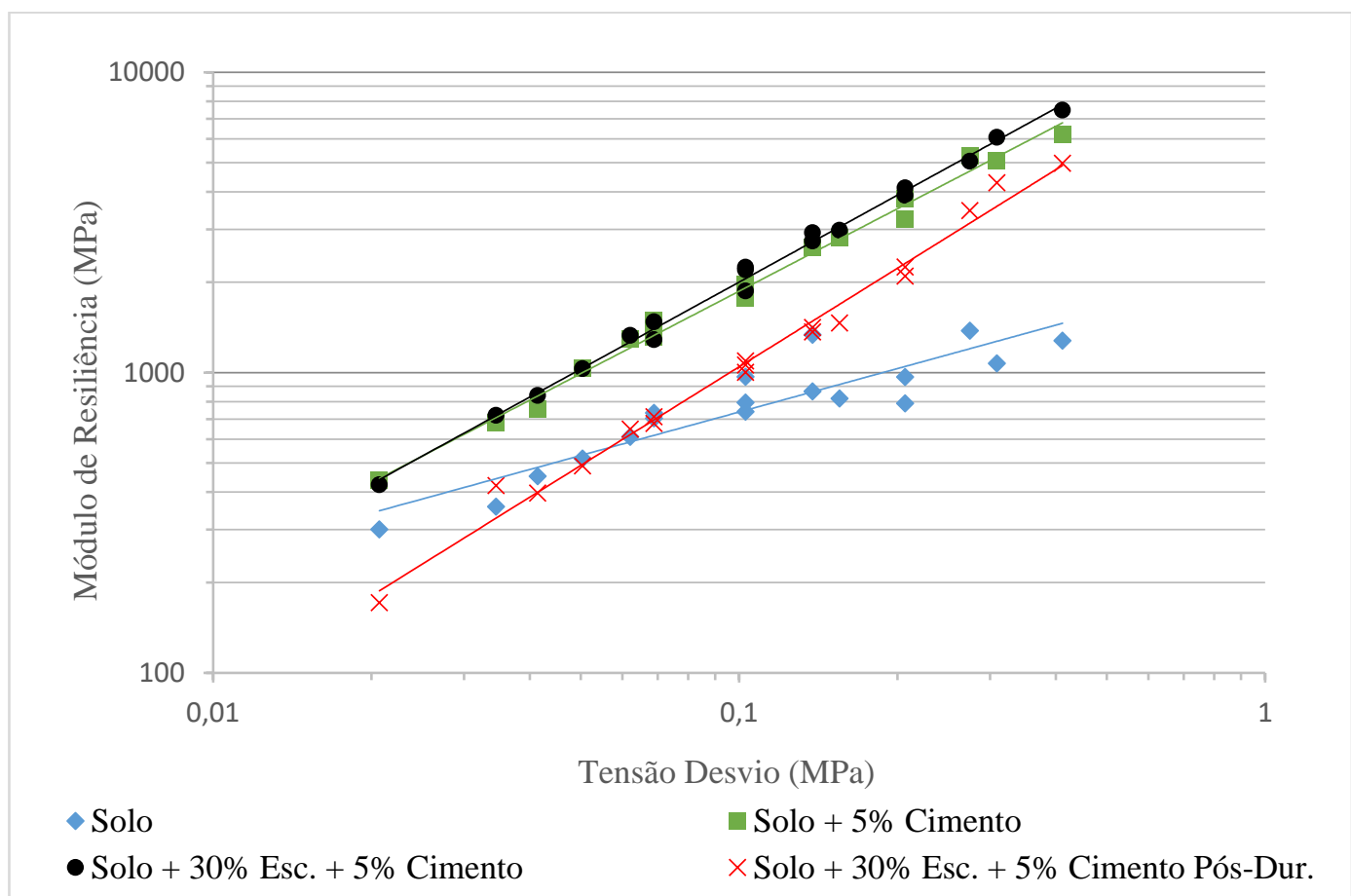

Figura 4.38 Módulo de resiliência (MPa) versus tensão desvio (MPa) para as misturas e o solo puro, em escala logarítmica.

Portanto, os resultados apresentados indicam que a adição de $30 \%$ de escória de cobre pós-jateada não altera a mistura em termos de deformabilidade, obtendo- 
se módulos variando de 400 a cerca de $8000 \mathrm{MPa}$, valores superiores aos obtidos com o solo puro e outros materiais de base granular normalmente empregados no Brasil e fora do país, conforme indica Motta e Macêdo (2006).

A Tabela 4.28 apresenta os valores da resistência à tração por compressão diametral. Para efeito de comparação e mostrar os ganhos de resistência, foi realizado o mesmo ensaio para o solo puro e para a mistura do solo com $30 \%$ de escória.

Tabela 4.28 Resistência à tração por compressão diametral do solo, escória de cobre pós-jateada e cimento Portland.

\begin{tabular}{c|c|c|c|c|c|c}
\hline \multirow{2}{*}{$\begin{array}{c}\text { Teor de } \\
\text { cimento (\%) }\end{array}$} & \multicolumn{5}{|c}{ Resistência à tração (MPa) } \\
\cline { 2 - 7 } & \multicolumn{3}{|c}{$0 \%$ Escória } & \multicolumn{3}{c}{$30 \%$ Escória } \\
\hline 0 & 0,046 & 0,042 & 0,051 & 0,055 & 0,055 & 0,050 \\
\hline 5 & 0,47 & 0,47 & 0,54 & 0,48 & 0,48 & 0,48 \\
\hline
\end{tabular}

Observa-se o ganho de resistência ao adicionar 5\% de cimento Portland com $30 \%$ de escória em relação ao solo puro e à mistura do solo com $30 \%$ de escória. No entanto, comparando-se os valores para a mistura de 5\% de cimento com e sem $30 \%$ de escória, observa-se não haver diferenças significativas entre as misturas, o que se pode concluir que a adição de escória de cobre pós-jateada não afeta a resistência à tração por compressão diametral para 5\% de cimento. Comparando as resistências, Ceratti (1991) obteve uma resistência à tração de 0,92 MPa num solo A-2-6 (0) e SC com 8\% de cimento, enquanto Specht (2000), trabalhando com solo A-4 e SM, obteve uma resistência de 0,247 MPa para 3,5\% de cimento e 0,358 $\mathrm{MPa}$ para $7 \%$ de cimento.

A Figura 4.39 mostra os corpos de prova de 5\% de cimento com e sem $30 \%$ de escória após serem rompidos à tração. Observa-se da figura que eles romperam na direção da aplicação da força, semelhante ao que ocorre no concreto, o que pode ser atribuído à elevada rigidez do material após ação cimentante. Conforme frisado por Bernucci et al. (2006), os materiais granulares não possuem coesão e não resistem à tração, porém trabalham bem aos esforços de compressão. Mas, para os materiais cimentados, afirmam os autores, o acréscimo de cimento ou outros aditivos proporcionam acréscimos significativos de rigidez ao material natural, acompanhado de significativos aumentos nas resistências à compressão e também à tração. 
(a)

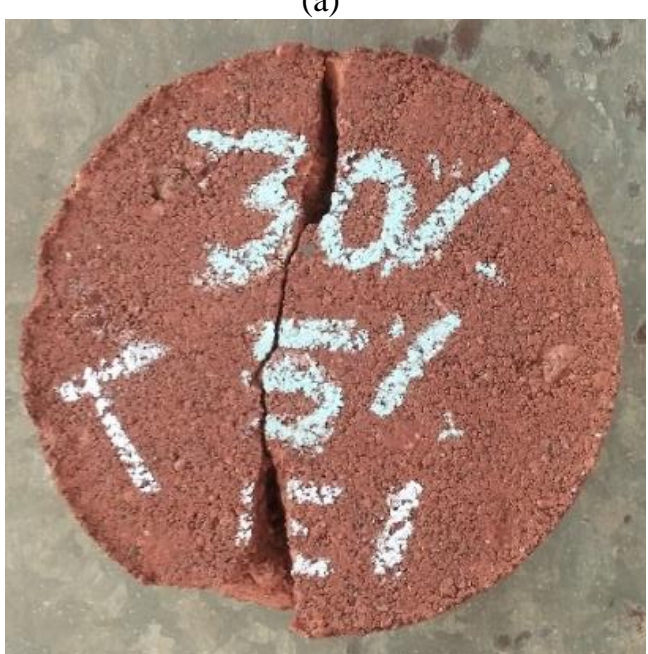

(b)

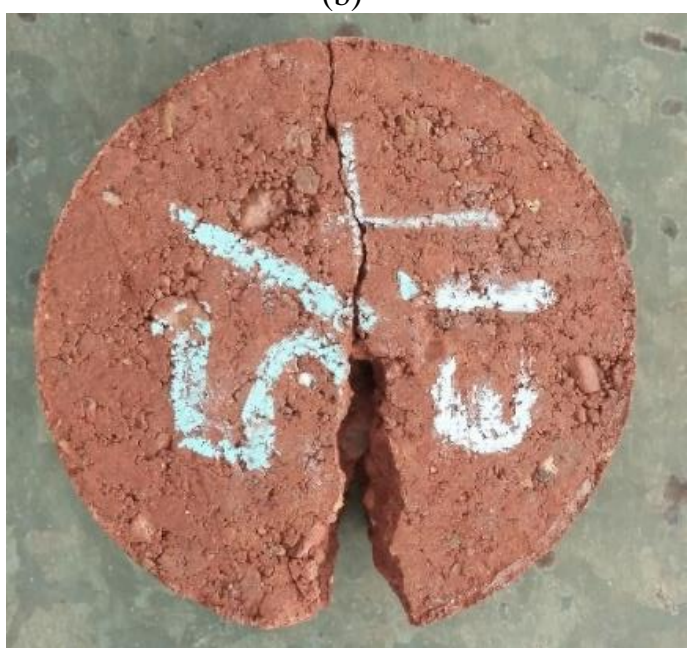

Figura 4.39 Corpos de provas do ensaio com 5\% de cimento e em (a) com 30\% de escória e em (b) $0 \%$ de escória.

\section{6}

\section{Correlações entre os parâmetros obtidos dos ensaios de resistência}

A partir dos resultados de resistência à compressão simples com os respectivos teores de cimento e de escória foram simuladas, através do programa RStudio, tentativas para obter correlações entre o teor de cimento e de escória. O intuito é possibilitar uma estimativa do valor de resistência em função dos teores de cimento e de escória.

A princípio foi simulado correlações lineares entre a resistência, teor de cimento e de escória, porém, não foram encontrados bons resultados. Ao analisar a resistência versus teor de cimento e resistência versus porcentagem de escória, observa-se que a correlação parecer ser quadrática (Figura 4.40 e 4.41) com a concavidade da parábola do teor de cimento voltada para cima e a da escória voltada para baixo. 


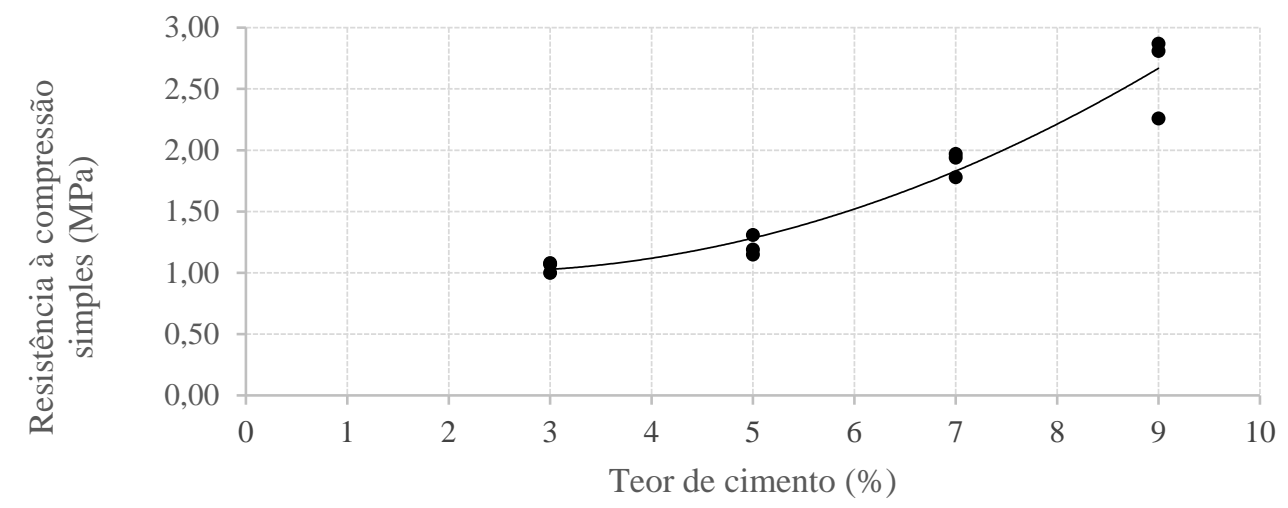

Figura 4.40 Resistência à compressão simples versus teor de cimento.

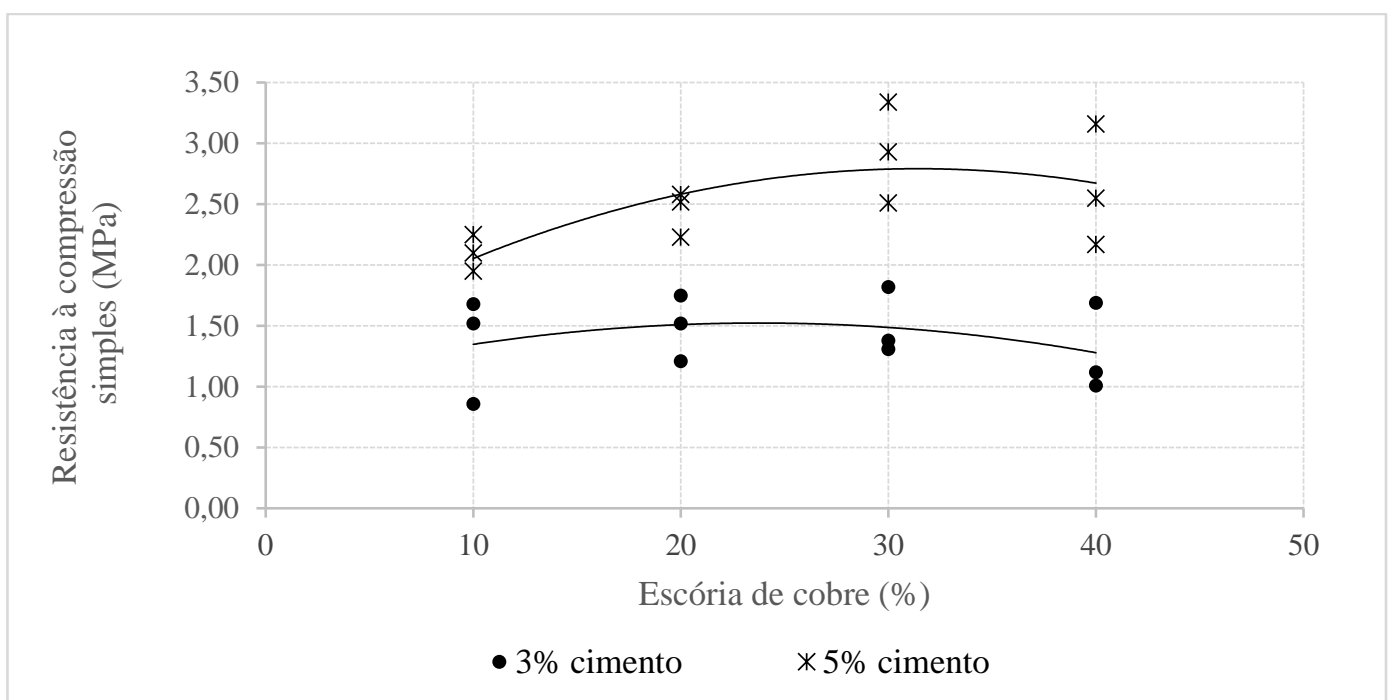

Figura 4.41 Resistência à compressão simples versus porcentagem de escória de cobre.

Esse comportamento indica que o teor de cimento cresce à medida que se aumenta o teor, mas não de forma linear. Diferentemente do comportamento quando se adiciona a escória, pois existirá um teor ótimo da mistura que, a partir dele, a resistência decresce e faz a concavidade ser voltada para baixo.

Diante dessa análise, foram realizadas novas simulações a partir de uma equação do tipo quadrática conforme apresentada na Equação 4.1:

$$
R C S=b o+b 1 \cdot E s c+b 2 \cdot E s c^{2}
$$

onde:

RCS - resistência à compressão simples

bo, b1, b2 - constantes

Esc - porcentagem de escória de cobre (em \%) 
Assim, foram obtidas as Equação 4.2 e 4.3, com confiabilidade de 90\%. A Equação 4.2 é válida para um teor de 3\% de cimento e a Equação 4.3, para 5\% de cimento. Tentativas para obter uma equação única em função também do teor de cimento foram realizadas. No entanto, não foi possível chegar a bons resultados dado apenas análises de dois teores de cimento.

$$
\begin{array}{lll}
R C S=1,044+0,0399 \cdot E s c-0,00085 \cdot E s c^{2} & \mathrm{R}^{2}=0,9933 & \text { (Eq. 4.2) } \\
R C S=1,21828+0,09964 . E s c-0,00157 . E s c^{2} & \mathrm{R}^{2}=0,9744
\end{array}
$$

Tomando como referência essas equações, estimativas de resistência foram realizadas e comparadas com as obtidas nos ensaios e o resultado é apresentado na Tabela 4.29. Verifica-se que as equações obtidas igualaram a bons resultados, com uma aproximação maior para $3 \%$ de cimento. Já para o teor de $5 \%$, houve uma maior diferença entre a equação e o resultado ensaiado, principalmente para os teores de escória de 20 e $30 \%$.

Tabela 4.29 Comparação de resistência à compressão simples entre as Equações 1 e 2 e os resultados

\begin{tabular}{|c|c|c|c|c|c|}
\hline \multicolumn{3}{|c|}{$3 \%$ Cimento } & \multicolumn{3}{|c|}{$5 \%$ Cimento } \\
\hline Escória & RCS simulado & RCS do ensaio & Escória & RCS simulado & RCS do ensaio \\
\hline 0 & 1,04 & 1,05 & 0 & 1,22 & 1,22 \\
\hline 10 & 1,36 & 1,35 & 10 & 2,06 & 2,10 \\
\hline 20 & 1,50 & 1,49 & 20 & 2,58 & 2,44 \\
\hline 30 & 1,48 & 1,50 & 30 & 2,79 & 2,93 \\
\hline 40 & 1,28 & 1,27 & 40 & 2,69 & 2,63 \\
\hline
\end{tabular}
ensaiados.

Em relação ao nível de confiabilidade dessas equações ser de $90 \%$, acreditase ser um nível aceitável em virtude de fatores que podem interferir nos resultados de resistência no momento da homogeneização da mistura, da quantidade de água adicionada à mistura, a moldagem dos corpos de prova e fração granulométrica do solo.

Parâmetros obtidos a partir da moldagem dos corpos de prova estão reunidos na Tabela 4.30 que podem justificar diferenças de resistência. 
Tabela 4.30 Dados gerais de cada amostra.

\begin{tabular}{|c|c|c|c|c|c|c|c|c|c|}
\hline Mistura & $\begin{array}{l}\text { RCS } \\
\text { (MPa) }\end{array}$ & $\begin{array}{l}\gamma / \operatorname{dmax} \\
\left(\mathrm{g} / \mathrm{cm}^{3}\right)\end{array}$ & e & $\mathrm{n}(\%)$ & $\begin{array}{c}\omega \\
\text { moldagem } \\
(\%)\end{array}$ & $\mathrm{Vv}\left(\mathrm{cm}^{3}\right)$ & $\operatorname{Vci}\left(\mathrm{cm}^{3}\right)$ & $\mathrm{a} / \mathrm{ci}$ & $\mathrm{Vv} / \mathrm{Vci}$ \\
\hline \multirow{3}{*}{$\begin{array}{c}40 \% \mathrm{ESC}+5 \% \\
\mathrm{Cim}\end{array}$} & 3,16 & 2,37 & 0,291 & 22,5 & 8,0 & 358,1 & 63,08 & 1,47 & 5,68 \\
\hline & 2,55 & 2,28 & 0,340 & 25,4 & 6,4 & 404,1 & 66,23 & 1,20 & 6,10 \\
\hline & 2,17 & 2,33 & 0,314 & 23,9 & 6,5 & 380,9 & 66,23 & 1,20 & 5,75 \\
\hline \multirow{3}{*}{$\begin{array}{c}40 \% \mathrm{ESC}+3 \% \\
\mathrm{Cim}\end{array}$} & 1,69 & 2,36 & 0,280 & 21,9 & 7,7 & 347,8 & 39,54 & 2,35 & 8,80 \\
\hline & 1,12 & 2,33 & 0,299 & 23,0 & 7,4 & 366,7 & 40,53 & 2,08 & 9,05 \\
\hline & 1,01 & 2,33 & 0,294 & 22,7 & 7,6 & 361,9 & 40,53 & 2,08 & 8,93 \\
\hline \multirow{3}{*}{$\begin{array}{c}30 \% \mathrm{ESC}+5 \% \\
\mathrm{Cim}\end{array}$} & 3,34 & 2,31 & 0,274 & 21,5 & 8,2 & 341,3 & 66,23 & 1,40 & 5,15 \\
\hline & 2,51 & 2,29 & 0,286 & 22,2 & 6,7 & 353,9 & 66,23 & 1,25 & 5,34 \\
\hline & 2,93 & 2,27 & 0,297 & 22,9 & 6,7 & 365,3 & 66,23 & 1,25 & 5,52 \\
\hline \multirow{3}{*}{$\begin{array}{c}30 \% \text { ESC }+3 \% \\
\text { Cim }\end{array}$} & 1,82 & 2,32 & 0,275 & 21,6 & 7,5 & 343,2 & 39,54 & 2,35 & 8,68 \\
\hline & 1,31 & 2,27 & 0,302 & 23,2 & 7,0 & 369,6 & 39,54 & 1,97 & 9,35 \\
\hline & 1,38 & 2,28 & 0,299 & 23,0 & 7,3 & 367,7 & 39,54 & 2,01 & 9,30 \\
\hline \multirow{3}{*}{$\begin{array}{c}20 \% \mathrm{ESC}+5 \% \\
\mathrm{Cim}\end{array}$} & 2,52 & 2,26 & 0,272 & 21,4 & 9,1 & 338,3 & 63,08 & 1,57 & 5,36 \\
\hline & 2,58 & 2,23 & 0,286 & 22,3 & 7,4 & 354,9 & 66,23 & 1,30 & 5,36 \\
\hline & 2,23 & 2,22 & 0,292 & 22,6 & 7,3 & 360,3 & 66,23 & 1,30 & 5,44 \\
\hline \multirow{3}{*}{$\begin{array}{l}20 \% \mathrm{ESC}+3 \% \\
\quad \mathrm{Cim}\end{array}$} & 1,75 & 2,27 & 0,274 & 21,5 & 7,7 & 342,8 & 38,61 & 2,40 & 8,88 \\
\hline & 1,52 & 2,21 & 0,307 & 23,5 & 7,7 & 374,5 & 39,54 & 2,09 & 9,47 \\
\hline & 1,21 & 2,22 & 0,301 & 23,1 & 7,4 & 368,9 & 39,54 & 2,01 & 9,33 \\
\hline \multirow{3}{*}{$\begin{array}{l}10 \% \mathrm{ESC}+9 \% \\
\mathrm{Cim}\end{array}$} & 3,75 & 2,19 & 0,286 & 22,2 & 9,3 & 354,3 & 109,37 & 0,97 & 3,24 \\
\hline & 4,18 & 2,20 & 0,284 & 22,1 & 9,2 & 352,3 & 109,37 & 0,94 & 3,22 \\
\hline & 3,82 & 2,24 & 0,259 & 20,6 & 9,3 & 319,2 & 109,37 & 1,01 & 2,92 \\
\hline
\end{tabular}


Tabela 4.30 Dados gerais de cada amostra (continuação).

\begin{tabular}{|c|c|c|c|c|c|c|c|c|c|}
\hline Mistura & $\begin{array}{l}\mathrm{RCS} \\
(\mathrm{MPa})\end{array}$ & $\begin{array}{c}\gamma_{\mathrm{dmax}} \\
\left(\mathrm{g} / \mathrm{cm}^{3}\right)\end{array}$ & e & $\mathrm{n}(\%)$ & $\begin{array}{c}\omega \\
\text { moldagem } \\
(\%)\end{array}$ & $\mathrm{Vv}\left(\mathrm{cm}^{3}\right)$ & $\operatorname{Vci}\left(\mathrm{cm}^{3}\right)$ & $\mathrm{a} / \mathrm{ci}$ & $\mathrm{Vv} / \mathrm{Vci}$ \\
\hline \multirow{3}{*}{$\begin{array}{c}10 \% \mathrm{ESC}+7 \% \\
\mathrm{Cim}\end{array}$} & 3,08 & 2,19 & 0,281 & 22,0 & 8,7 & 349,8 & 86,66 & 1,13 & 4,04 \\
\hline & 2,92 & 2,20 & 0,277 & 21,7 & 8,6 & 345,0 & 86,66 & 1,13 & 3,98 \\
\hline & 2,75 & 2,20 & 0,280 & 21,9 & 8,8 & 348,7 & 86,66 & 1,13 & 4,02 \\
\hline \multirow{3}{*}{$\begin{array}{c}10 \% \mathrm{ESC}+5 \% \\
\mathrm{Cim}\end{array}$} & 2,10 & 2,20 & 0,274 & 21,5 & 8,0 & 342,3 & 64,64 & 1,43 & 5,30 \\
\hline & 2,25 & 2,18 & 0,283 & 22,0 & 7,9 & 350,5 & 64,64 & 1,41 & 5,42 \\
\hline & 1,95 & 2,21 & 0,270 & 21,3 & 8,0 & 338,2 & 64,64 & 1,43 & 5,23 \\
\hline \multirow{3}{*}{$\begin{array}{c}10 \% \mathrm{ESC}+3 \% \\
\mathrm{Cim}\end{array}$} & 1,68 & 2,21 & 0,269 & 21,2 & 8,5 & 337,3 & 38,58 & 2,53 & 8,74 \\
\hline & 1,52 & 2,21 & 0,265 & 21,0 & 8,4 & 334,1 & 38,58 & 2,45 & 8,66 \\
\hline & 0,86 & 2,17 & 0,293 & 22,7 & 8,1 & 361,5 & 38,58 & 2,27 & 9,37 \\
\hline \multirow{3}{*}{$9 \%$ CIM } & 2,26 & 2,12 & 0,295 & 22,8 & 8,3 & 362,9 & 118,31 & 0,85 & 3,07 \\
\hline & 2,87 & 2,12 & 0,300 & 23,1 & 8,5 & 367,2 & 118,31 & 0,84 & 3,10 \\
\hline & 2,81 & 2,13 & 0,294 & 22,7 & 8,3 & 360,6 & 118,31 & 0,87 & 3,05 \\
\hline \multirow{3}{*}{ 7\% CIM } & 1,78 & 2,12 & 0,290 & 22,5 & 8,4 & 357,2 & 92,02 & 1,03 & 3,88 \\
\hline & 1,94 & 2,12 & 0,290 & 22,5 & 8,4 & 354,1 & 92,02 & 1,03 & 3,85 \\
\hline & 1,97 & 2,12 & 0,291 & 22,5 & 8,6 & 358,1 & 92,02 & 1,03 & 3,89 \\
\hline \multirow{3}{*}{$5 \%$ CIM } & 1,31 & 2,11 & 0,290 & 22,5 & 8,4 & 358,1 & 65,73 & 1,55 & 5,45 \\
\hline & 1,19 & 2,14 & 0,271 & 21,3 & 8,4 & 339,7 & 65,73 & 1,34 & 5,17 \\
\hline & 1,15 & 2,10 & 0,295 & 22,8 & 8,5 & 362,3 & 65,73 & 1,44 & 5,51 \\
\hline \multirow{3}{*}{$3 \%$ CIM } & 1,07 & 2,12 & 0,281 & 21,9 & 8,5 & 348,8 & 39,44 & 2,41 & 8,85 \\
\hline & 1,08 & 2,12 & 0,284 & 22,1 & 8,6 & 351,9 & 39,44 & 2,37 & 8,92 \\
\hline & 1,00 & 2,12 & 0,285 & 22,2 & 8,6 & 353,9 & 39,44 & 2,27 & 8,97 \\
\hline
\end{tabular}


O gráfico apresentado na Figura 4.42 mostra a dispersão que ocorreu nos corpos de prova em relação à água adicionada na moldagem, dada pelo fator água/cimento, versus resistência. Em várias repetições das moldagens, ao adicionar o cimento à mistura, nota-se que o solo tendia a diminuir a umidade, fazendo com que em algumas moldagens fossem adicionadas mais água do que em outras. Daí a dispersão de resultados entre a quantidade de água, cimento e a resistência obtida. Pode-se observar que a mesma relação água/cimento pode ser obtida resistências diferentes.

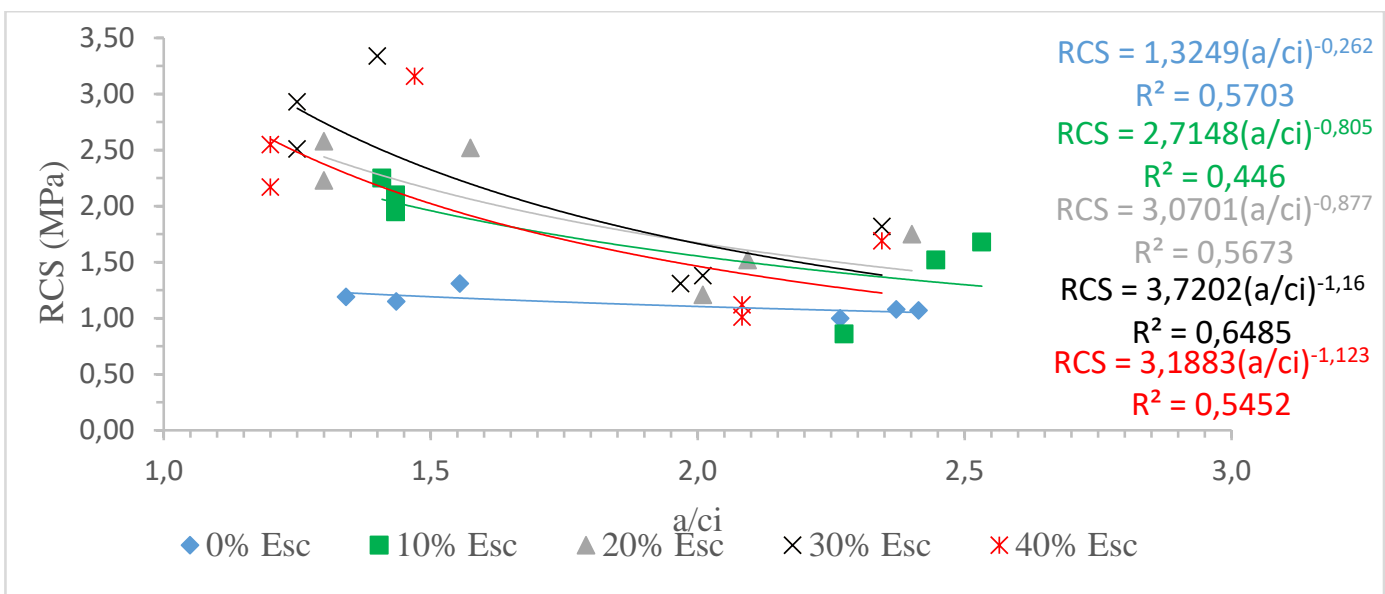

Figura 4.42 Resistência â compressão simples versus fator água/cimento.

Nos estudos com solo-cimento, Foppa (2005) e Consoli et al. (2007) verificaram uma dispersão entre o fator água/cimento e a resistência para as misturas. Vale destacar que os autores trabalharam com variações de umidade, teores de cimento e massa específica aparente seca máxima. Segundo Foppa (2005), Consoli et al. (2007) e Fonseca et al. (2009), o papel desempenhado pelos vazios e pela quantidade de água são diferentes: enquanto a água afeta diretamente a resistência por alterar sua estrutura, os vazios afetam diretamente a resistência por alterar o número de pontos de contato entre as partículas.

Os resultados apresentados na Tabela 4.30 mostram que menores porosidades levam a resultados a resultados maiores de resistência. Porém, observa-se também que houveram misturas que isso não ocorreu, principalmente para as misturas com $10 \%$ de escória.

Foppa (2005) e Consoli et al. (2007) verificaram que a resistência aumentou exponencialmente com a redução da porosidade da mistura compactada. Isso pode ser dado pelo fato de que menor quantidade de poros significa que os contatos entre 
os grãos são maiores, havendo um intertravamento entre as partículas e, consequentemente, aumento na resistência. Acrescenta-se ainda a união mais efetiva dessas partículas por conta da adição do cimento Portland. É importante frisar que a muitos dos vazios deixados pelas partículas do solo são preenchidos pelos grãos do solo, o que faz aumentar o contato entre eles para uma melhor ação modificadora e/ou aglutinadora do aditivo.

Observa-se ainda da Tabela 4.30 que as maiores resistências foram alcançadas para maiores massas específicas aparentes secas. Verifica-se também que para as mesmas massas foi possível obter resistências diferentes. Isso pode ser explicado, pois maiores densidades coexistem com maiores contatos entre as partículas cimentadas. Assim, esse contato, juntamente com o poder de união do cimento entre as partículas do solo e da escória de cobre, implica em maiores resistências.

Uma melhor correlação pode ser obtida entre os parâmetros mostrados na Tabela 4.30: resistência versus volume de vazios (Vv) / volume de cimento (Vci). Os gráficos estão apresentados na Figura 4.43. Comparando essa com o fator água/cimento e com $\mathrm{Vv} / \mathrm{Vci}$, mostra-se que esta tem melhores correlações devido às menores dispersões dos resultados, e que há uma tendência de menores relações atingem maiores resistências.

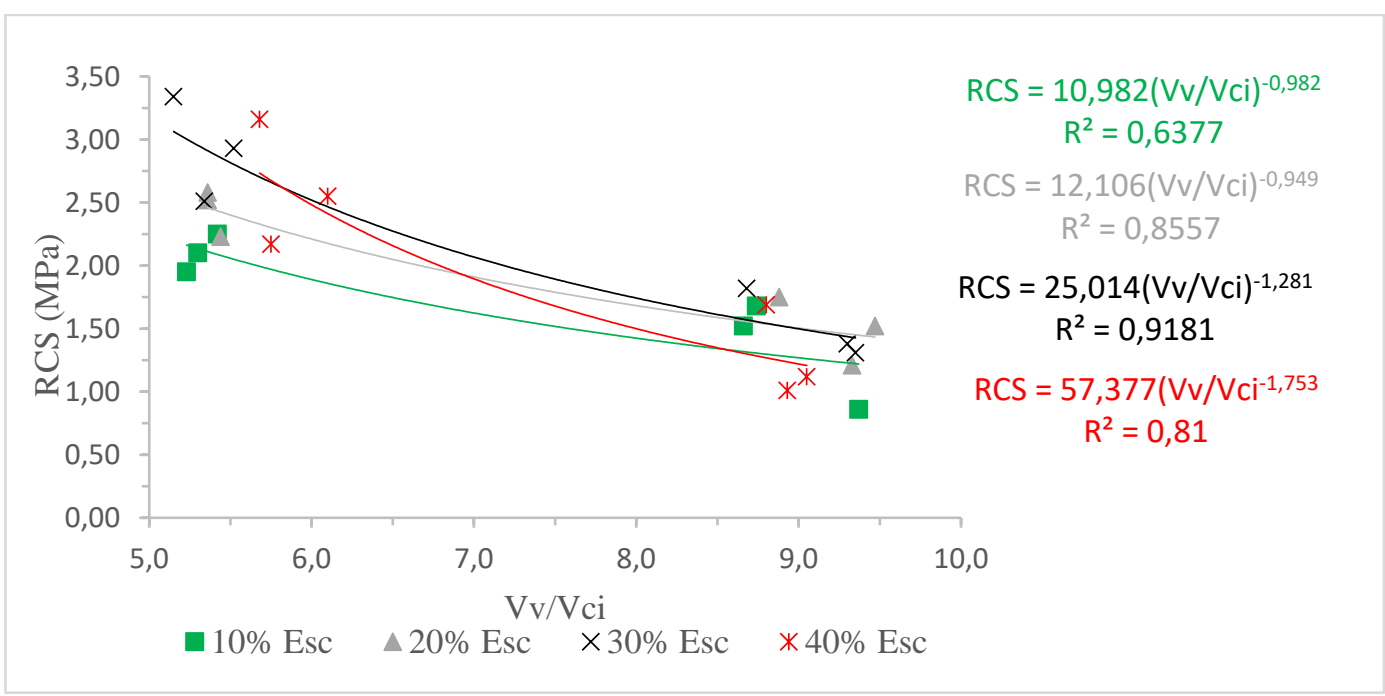

Figura 4.43 Resistência à compressão simples versus Vv/Vci.

Considerando as possibilidades dos ensaios realizados para esta tese, a mistura com $30 \%$ de escória de cobre pós-jateada foi a que apresentou a melhor relação $\mathrm{Vv} / \mathrm{V}$ ci, definido pelo coeficiente de determinação $\left(\mathrm{R}^{2}\right)$. Isso comprova, 
conforme já discutido, que nas estabilizações granulométrica e química, esse teor de escória mostrou-se ser o mais indicado, reduzindo os vazios e elevando a resistência, devido ao preenchimento dos vazios do solo pelas partículas da escória, além de proporcionar um maior contato entre as partículas envolvidas, o que faz reduzir o teor de cimento na estabilização. Além disso, há redução na permeabilidade, plasticidade, aumento da rigidez, não afetando a durabilidade nem a resistência à tração.

\section{7}

\section{Considerações finais}

Neste capítulo foram apresentados e discutidos os resultados obtidos na pesquisa que permitiram alcançar os objetivos a partir dos ensaios de caracterização do solo, da escória, das misturas solo-cimento, solo-escória e solo-escória-cimento, ensaios mecânicos, ambientais, mineralógicos e permeabilidade. Foi possível determinar a melhor mistura entre os materiais para aplicação na estrutura do pavimento. Além disso, chegou-se a boas correlações entre a resistência e a porcentagem de cimento.

No capítulo a seguir será apresentado algumas de simulações da estrutura do pavimento utilizando o programa SisPav e como dados de entrada os resultados dos materiais estudados. 


\section{5 \\ Dimensionamento de um pavimento com o material de estudo}

O programa utilizado para simular o dimensionamento do pavimento foi o SisPav, desenvolvido por Franco (2007), sob a orientação da Profa. Laura Motta, da COPPE/UFRJ com o objetivo de realizar análises e dimensionamentos de estruturas de pavimentos segundo os conceitos relativos ao estado da arte da mecânica dos pavimentos (FRANCO, 2007).

O SisPav realiza o dimensionamento por processo de análise e dimensionamento mecanístico-empírico, utilizando a teoria da elasticidade, por meio do programa AEMC (Análise Elástica de Múltiplas Camadas) com uma abordagem da análise elástica não linear realizada de forma simplificada, com a divisão das camadas com este comportamento em três subcamadas (FRANCO, 2007).

O programa permite duas opções de análise: a primeira é o dimensionamento da estrutura, em que é analisada os dados de entrada e, através de um algoritmo similar ao de busca binária em tabela ordenada, encontra a espessura da camada que atenda aos requisitos de projeto. Já a segunda análise, realiza uma verificação dos dados e requisitos definidos pelo projetista e informa a vida de projeto que a estrutura pode suportar (FRANCO, 2007).

Por essas duas análises, o SisPav verifica os danos acumulados por fadiga no revestimento asfálticos ou, se for o caso, na base das camadas cimentadas. Com opção, o projetista pode solicitar as estimativas de afundamento de trilha de roda e dos danos relativos à deflexão máxima na superfície do pavimento e à tensão limite no topo do subleito (FRANCO, 2007).

Os detalhes de informações sobre os dados de entrada no programa estão descritos a seguir:

\section{- TRÁFEGO}

Admitiu-se um valor de $\mathrm{N}$ de 1 x $10^{5}$, para eixo padrão rodoviário. A Figura 5.1 mostra a tela do SisPav com as informações da aba $<$ carregamento $>$. A ideia 
é que o material aqui estudado sirva como base de pavimentos para baixo volume de tráfego.

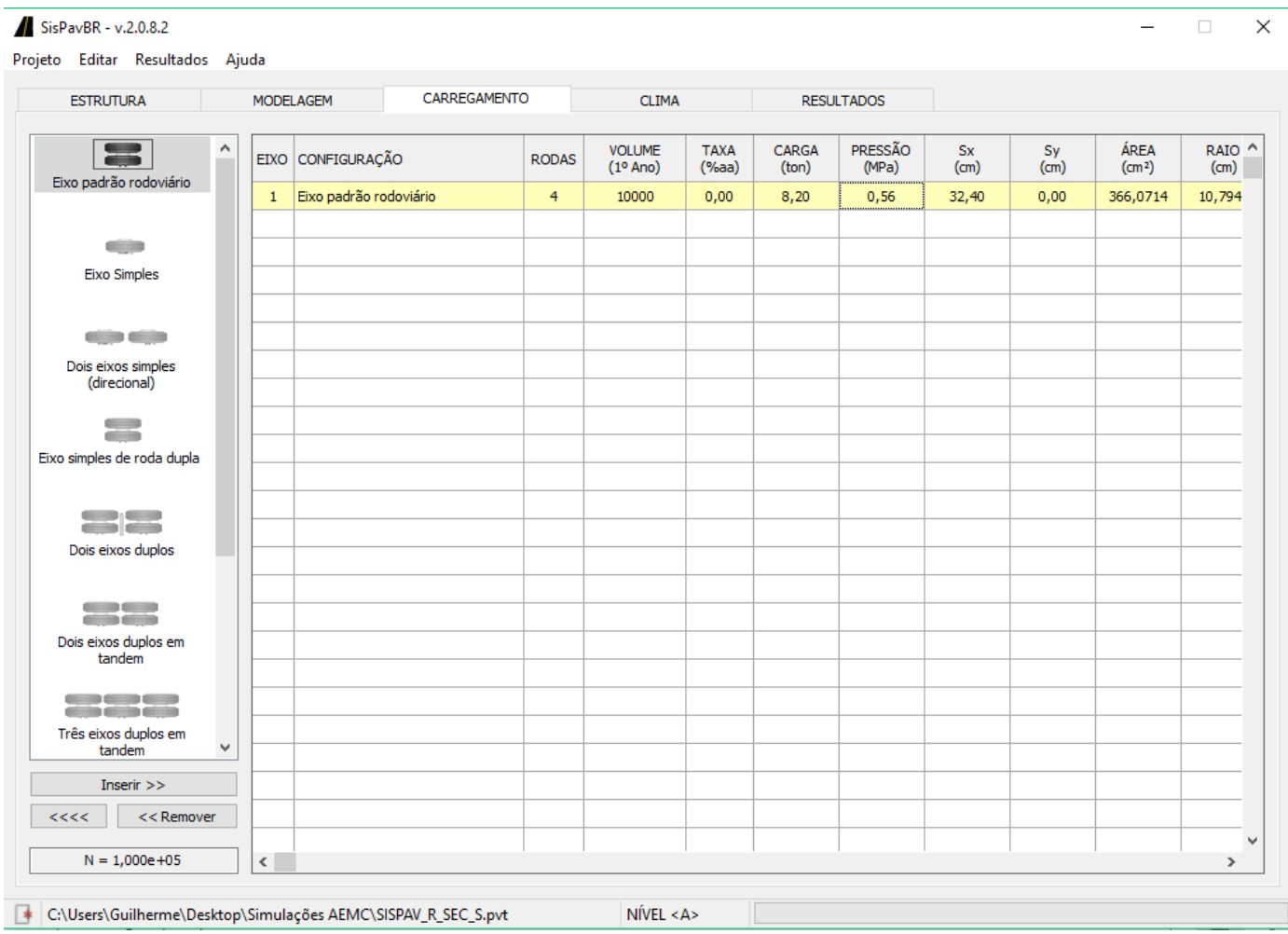

Figura 5.1 Tela SisPav na aba < carregamento > para o cálculo do tráfego.

- CLIMA

Admitiu-se na opção clima a cidade de Aracaju como alternativa da construção do pavimento simulado, conforme mostra a Figura 5.2. O banco de dados interno do programa foi obtido das Normais Climatológicas, segundo descreve Franco (2007). 


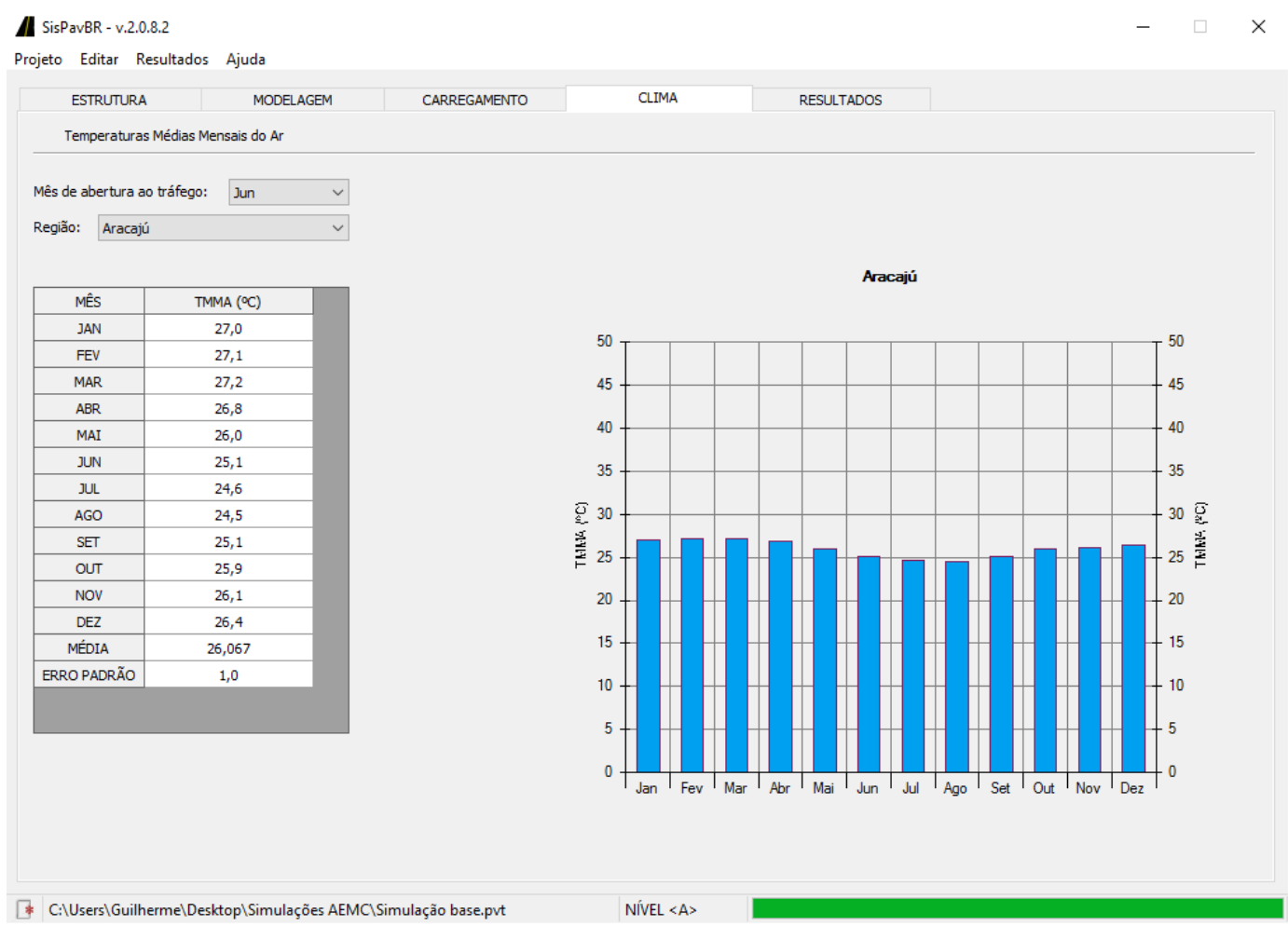

Figura 5.2 Tela SisPav na aba < clima $>$.

\section{- MATERIAIS}

Para o revestimento, as simulações foram realizadas com tratamento superficial (TS) de 2,5 cm de espessura e concreto asfáltico (CA) de $5 \mathrm{~cm}$ de espessura, utilizando os dados para este material as referências da recente pesquisa de Santana (2016), que também estudou materiais do Estado de Sergipe, como descrito abaixo.

$$
\begin{array}{ll}
\checkmark & \text { MR }=3184,43 \mathrm{MPa} \\
\checkmark & \text { Granulometria }=\text { Faixa C } \\
\checkmark & \text { Volume de vazios }=4,0 \% \\
\checkmark & \text { Teor de asfalto }=5,5 \% \\
\checkmark & \text { Desgaste por Abrasão Los Angeles }=23,4 \%
\end{array}
$$

Para as camadas de base e sub-base são utilizadas misturas de solo-escóriacimento e o solo puro, com os dados obtidos nos ensaios. Para a camada de subleito é sugerido um valor hipotético de MR de $200 \mathrm{MPa}$, desde que este seja inferior ao material de sub-base.

O modelo matemático para o solo puro (material granular) foi o modelo composto como dados de entrada as constantes de regressão obtidas no ensaio de 
módulo de resiliência. Já para a mistura com cimento, o modelo considerado no programa é o módulo constante.

\section{1 \\ Simulações do pavimento}

As simulações do dimensionamento visam a menor espessura das camadas e para demonstrá-las foram testadas alternativas de materiais para a base e sub-base, mantendo a espessura do revestimento em $5 \mathrm{~cm}$ para o CA e 2,5 $\mathrm{cm}$ para o TS e as características subleito. Em seguida, foi testada a opção de pavimento invertido, isto é, simulações com o solo puro na base e a camada cimentada na sub-base, mantendo-se o mesmo revestimento e o mesmo subleito.

O SisPav admite espessuras entre $10 \mathrm{~cm} \mathrm{e} 60 \mathrm{~cm}$ para todas as camadas, com exceção do revestimento que varia de $5 \mathrm{~cm}$ a $20 \mathrm{~cm}$. Nas Figuras a seguir são mostradas algumas simulações realizadas com as espessuras mínimas considerando as camadas descritas com os valores obtidos nessa pesquisa.

O dimensionamento da estrutura, conforme apresentada na Figura 5.3, indicou um dano de cerca de $0,90 \%$ do tipo tensão admissível no topo do subleito e vida de projeto elevada. Espessuras menores que $30 \mathrm{~cm}$ na camada de base já causa um dano a fadiga na camada cimentada.

Outras simulações foram realizadas na tentativa de diminuir a espessura da base através do aumento da espessura da camada de sub-base e criando camada de reforço do subleito, mas a redução no dano é muito pouco para o aumento da camada. Em média, 0,10\% para cada $10 \mathrm{~cm}$ de sub-base. As Figuras 5.4 e Figura 5.5 apresentam as telas de saída do programa para as simulações com concreto asfáltico de tratamento superficial, respectivamente.

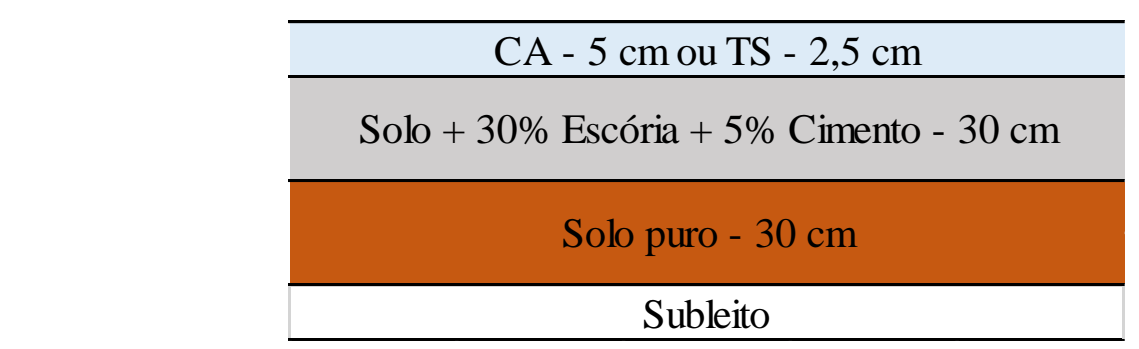

Figura 5.3 Estrutura 1 do pavimento simulado. 


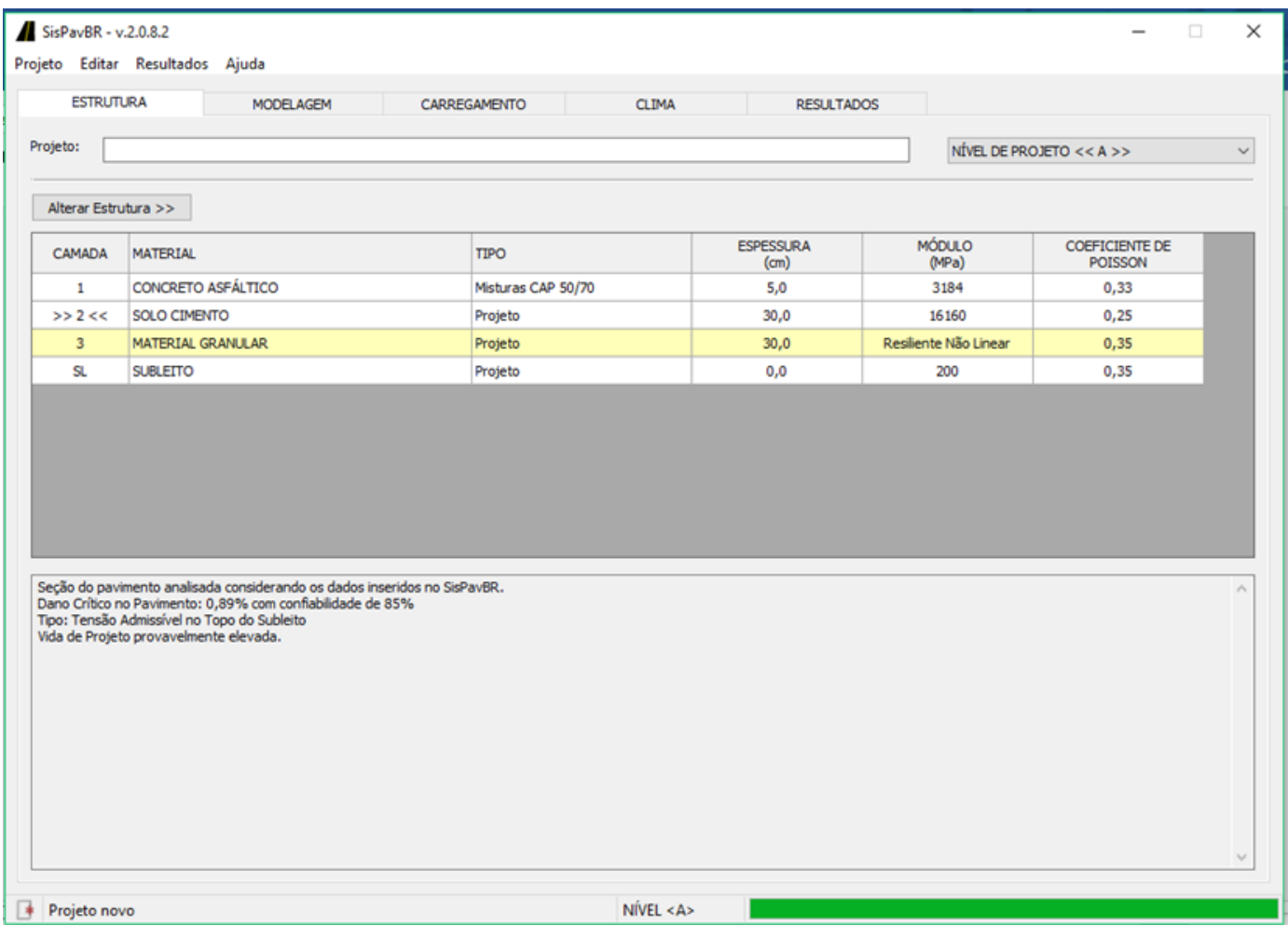

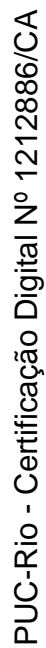

Figura 5.4 Tela SisPav do dimensionamento revestimento de CA $(5 \mathrm{~cm})$, base de solo $+30 \%$ escória $+5 \%$ cimento $(30 \mathrm{~cm})$ e sub-base de solo puro $(30 \mathrm{~cm})$.

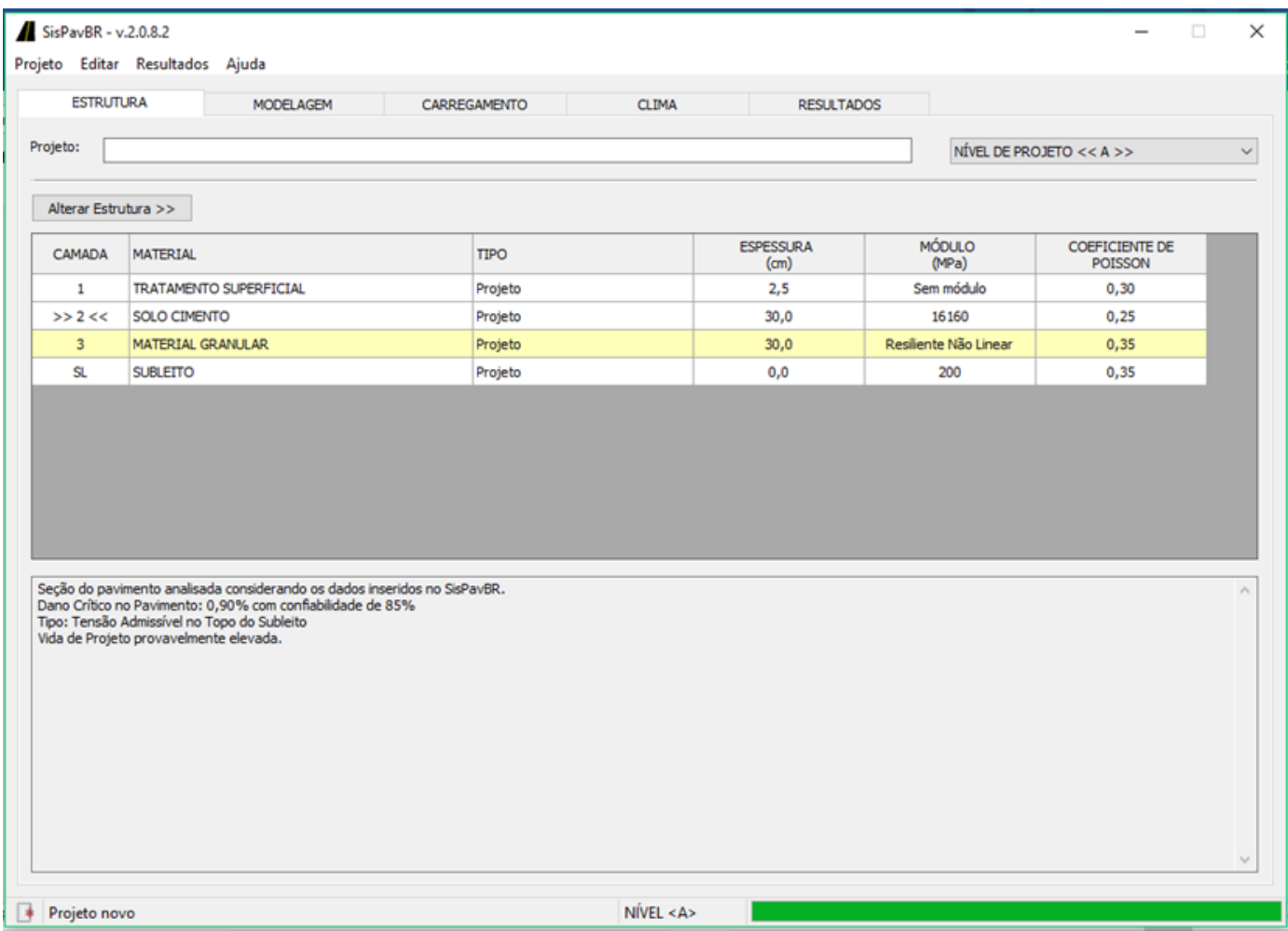

Figura 5.5 Tela SisPav do dimensionamento revestimento de TS $(2,5 \mathrm{~cm})$, base de solo $+30 \%$ escória $+5 \%$ cimento $(30 \mathrm{~cm})$ e sub-base de solo puro $(30 \mathrm{~cm})$. 
O dimensionamento realizado com a camada cimentada apoiada no subleito, conforme apresentada na Figura 5.6, indicou um dano de cerca de 1,30\% do tipo tensão admissível no topo do subleito e vida de projeto elevada. Espessuras menores que $30 \mathrm{~cm}$ na camada de base já causa um dano a fadiga na camada cimentada. As Figuras 5.7 e Figura 5.8 apresentam as telas de saída do programa para as simulações com concreto asfáltico de tratamento superficial, respectivamente.

\begin{tabular}{c}
\hline CA - 5 cm ou TS - $2,5 \mathrm{~cm}$ \\
\hline Solo $+30 \%$ Escória $+5 \%$ Cimento $-30 \mathrm{~cm}$ \\
Subleito
\end{tabular}

Figura 5.6 Estrutura 2 do pavimento simulado.

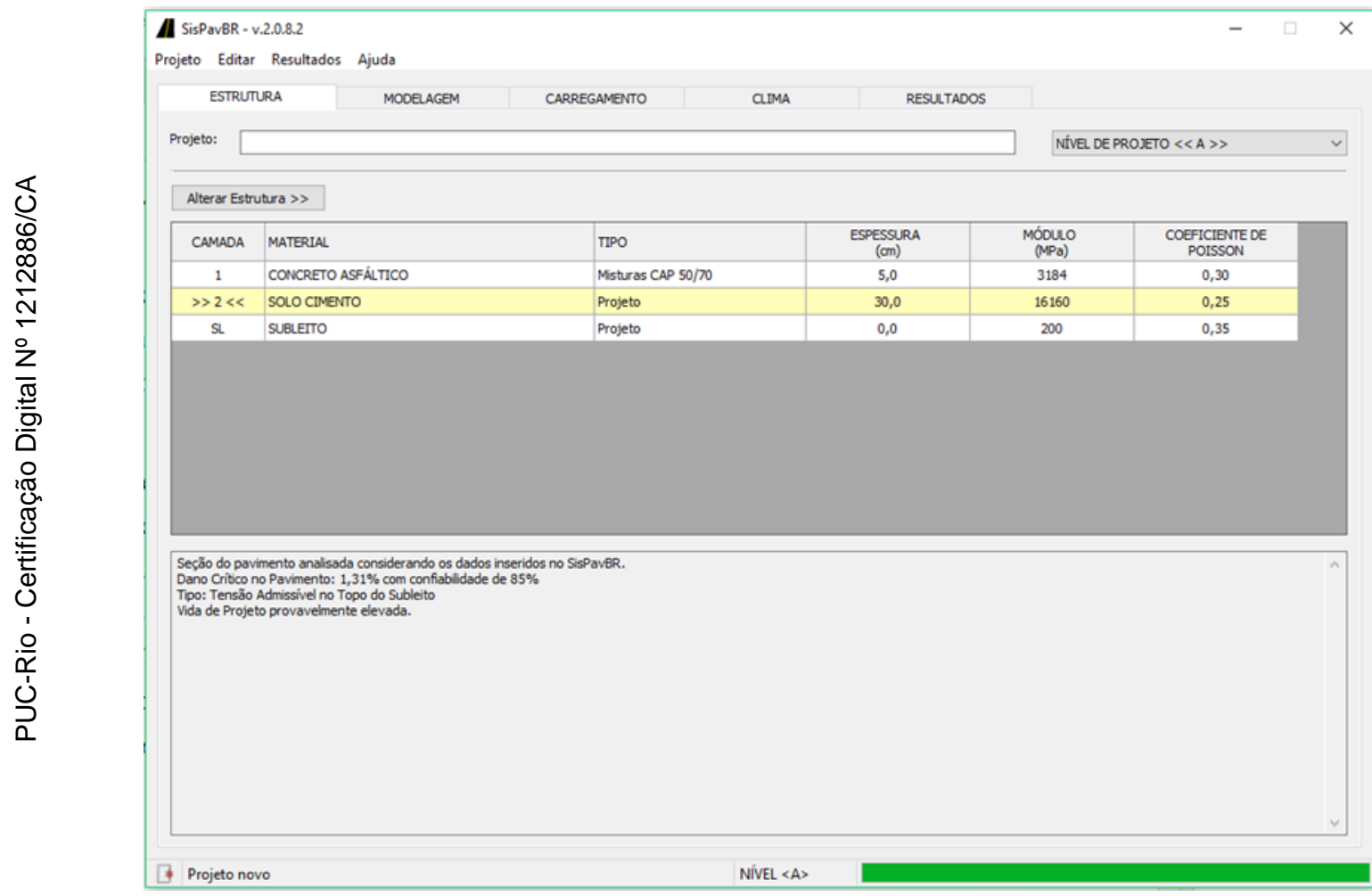

Figura 5.7 Tela SisPav do dimensionamento revestimento de CA $(5 \mathrm{~cm})$, base de solo $+30 \%$ escória $+5 \%$ cimento $(30 \mathrm{~cm})$. 


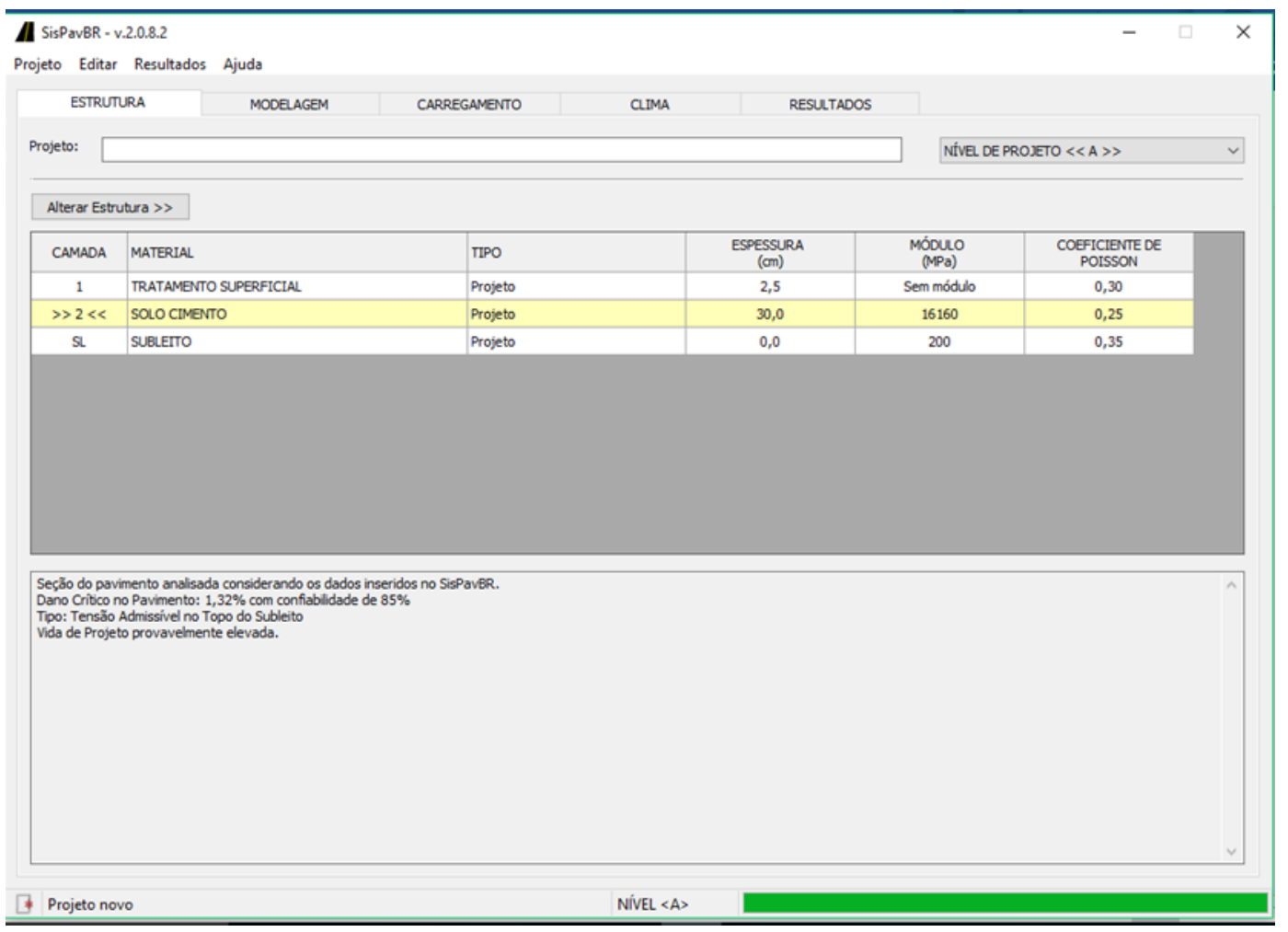

Figura 5.8 Tela SisPav do dimensionamento revestimento de TS $(2,5 \mathrm{~cm})$, base de solo $+30 \%$ escória $+5 \%$ cimento $(30 \mathrm{~cm})$.

Partindo-se da ideia do pavimento invertido, foi dimensionada a estrutura apresentada na Figura 5.9. Para a camada de revestimento de concreto asfáltico indicou um dano de cerca de 31,93\% do tipo fadiga da mistura asfáltica com vida de projeto estimada em 31,3 anos. Já para a camada de revestimento de tratamento superficial indicou um dano de cerca de $31,87 \%$, porém há fadiga na camada cimenta com vida de projeto estimada em 31,4 anos. Espessuras menores que as indicadas já ocorre fadiga na camada cimentada, independente do revestimento. As Figuras 5.10 e Figura 5.11 apresentam as telas de saída do programa para as simulações com concreto asfáltico de tratamento superficial, respectivamente.

\begin{tabular}{c}
\hline CA $-5 \mathrm{~cm}$ ou TS $-2,5 \mathrm{~cm}$ \\
\hline Solo puro $-20 \mathrm{~cm}$ \\
\hline Solo $+30 \%$ Escória $+5 \%$ Cimento $-25 \mathrm{~cm}$ \\
\hline Subleito \\
\hline
\end{tabular}

Figura 5.9 Estrutura 3 do pavimento simulado. 
ПI SisPavBR - v.2.0.8.2

Projeto Editar Resultados Ajuda

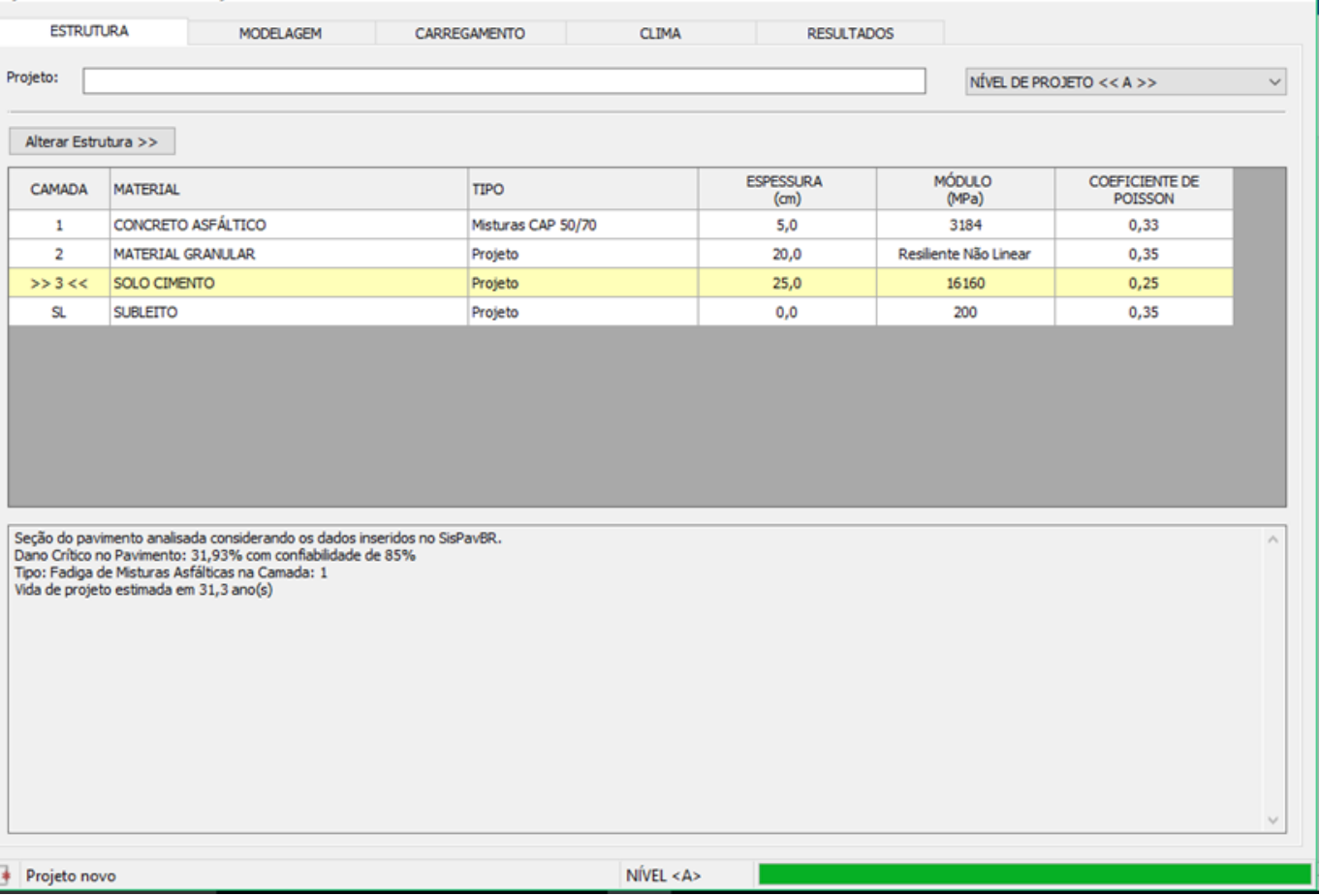

Figura 5.10 Tela SisPav do dimensionamento revestimento de CA $(5 \mathrm{~cm})$, base de solo puro $(20$ $\mathrm{cm})$ e sub-base de solo $+30 \%$ escória $+5 \%$ cimento $(25 \mathrm{~cm})$.

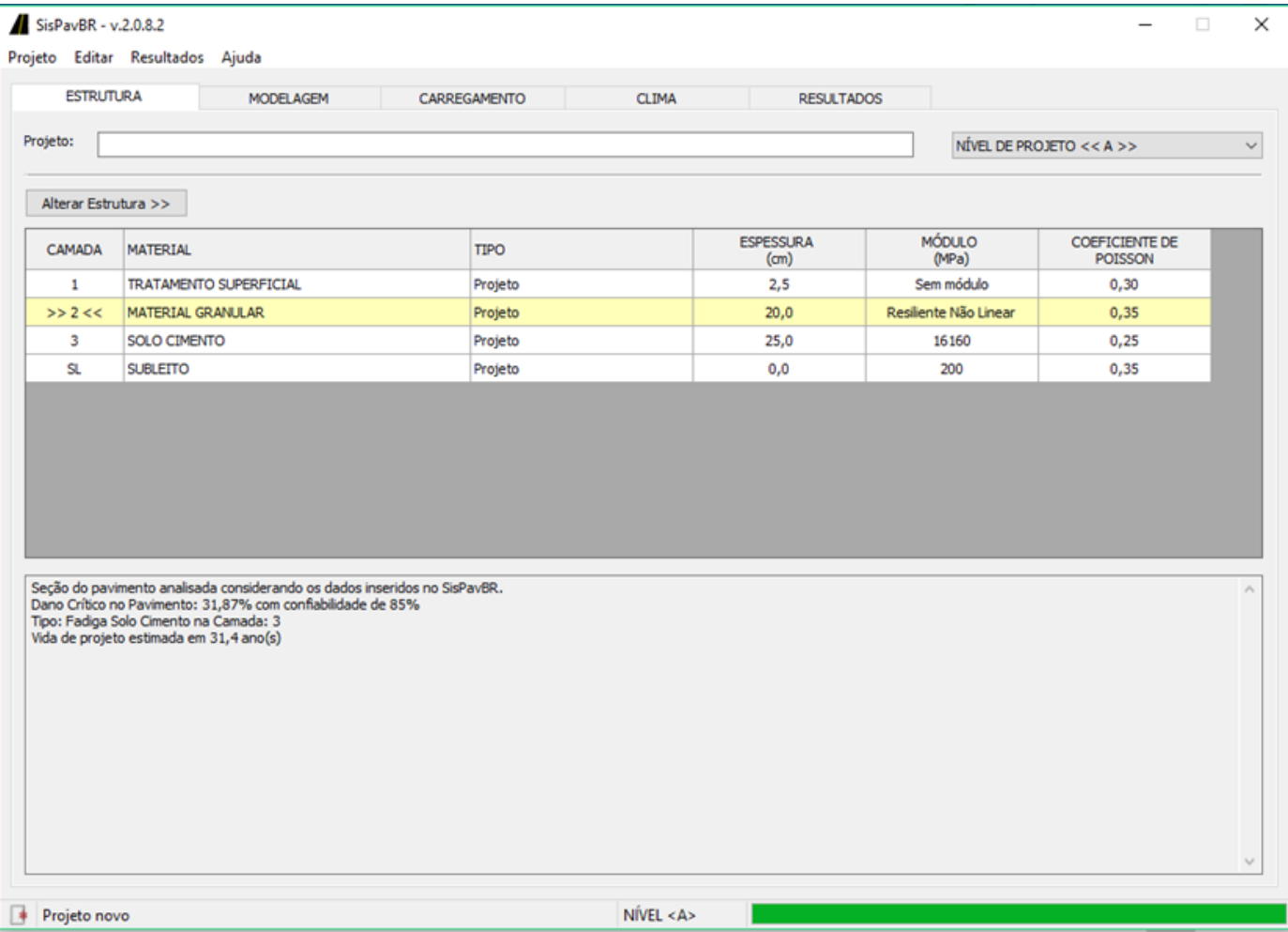

Figura 5.11 Tela SisPav do dimensionamento revestimento de TS $(2,5 \mathrm{~cm})$, base de solo puro (20 $\mathrm{cm})$ e sub-base de solo $+30 \%$ escória $+5 \%$ cimento $(25 \mathrm{~cm})$.

Das simulações apresentadas, considerando as características atribuídas ao revestimento e ao subleito, revelaram que a menor espessura da camada de base 
constituída de solo com $30 \%$ de escória e $5 \%$ de cimento foi de $30 \mathrm{~cm}$ podendo. Para o pavimento invertido com o revestimento em concreto asfáltico não apresentou fadiga na camada cimentada, diferente quando se utiliza o tratamento superficial, e ainda foi possível reduzir para $25 \mathrm{~cm}$ a espessura.

\section{2}

\section{Considerações finais}

Neste capítulo foram apresentadas algumas simulações da estrutura do pavimento com o material pesquisado. A mistura de solo, $30 \%$ de escória de cobre e 5\% de cimento sinaliza a possibilidade de aproveitamento do resíduo em base de pavimento, seja de pequenos acessos ou trechos com baixo volume de tráfego.

No capítulo a seguir serão apresentadas a contribuição desta pesquisa, as constatações observadas e sugestões para trabalhos futuros. 


\section{6 \\ Conclusões e Recomendações}

\section{1 Principal contribuição da pesquisa}

Os resultados e análises obtidos dos experimentos realizados indicam a possibilidade de utilização da escória de cobre proveniente das operações de jateamento de tanques de petróleo em base de pavimento. O resíduo, quando incorporado a uma matriz de solo areno-argiloso e cimento Portland, em uma porcentagem adequada, pode reduzir o teor do aditivo da mistura e contribuir na melhoria das propriedades geotécnicas desta, principalmente mecânica. Além disso, a pesquisa configura uma ação mitigadora de impactos ao meio ambiente, uma vez que se procura encontrar um destino para o resíduo descartado em aterro sanitário.

\section{2}

\section{Principais constatações do programa experimental}

A partir das ideias que justificaram estudar a incorporação da escória de cobre pós-jateada ao solo com porcentagens de cimento Portland, os objetivos da pesquisa foram alcançados e, com base no que foi exposto, chega-se às seguintes constatações:

- O acréscimo de escória altera a granulometria do solo, eleva a massa específica aparente seca máxima e reduz a umidade ótima, consequência da sua elevada densidade e baixa absorção dos grãos;

- Para o solo estudado, o teor de 3\% de cimento foi suficiente para modificá-lo, sendo necessário teores acima de 7\% para aglutinar os grãos do solo e atingir resistências acima de 2,1 MPa, com diferenças significativas em relação aos teores menores;

- A mistura de solo com $30 \%$ de escória foi a de maior resistência à compressão alcançada, indicando ser essa a porcentagem de melhor estabilização granulométrica, sem diferenças significativas entre as misturas; 
- A mistura de solo, 30\% de escória e 5\% de cimento foi a de maior resistência à compressão alcançada, indicando serem essas as porcentagens de escória e cimento, respectivamente, adequadas. Diferenças significativas ocorreram a partir da mistura com $10 \%$ de escória e 5\% de cimento;

- A incorporação de $30 \%$ de escória fez reduzir o teor de cimento, atingindo resistências acima de 2,1 $\mathrm{MPa}$, garantindo reduções nos custos, dada a redução do aditivo de maior valor econômico na mistura;

- As misturas com até $40 \%$ de escória reduziram a plasticidade a menos da metade e a adição de cimento, a partir de 5\% ao solo, o torna não plástico. As misturas a partir de $10 \%$ de escória e 3\% de cimento também passam a ser não plásticas;

- A mistura de solo, $30 \%$ de escória e 5\% de cimento apresentou menor permeabilidade, com redução de duas ordens de grandeza;

- Os módulos de resiliência para a mistura com 30\% de escória e 5\% de cimento, em comparação à mistura de solo e 5\% de cimento, não mostraram diferenças, porém, para a mistura com escória, os módulos foram um pouco maiores;

- A perda de massa por durabilidade da mistura de solo com $30 \%$ de escória e $5 \%$ de cimento foi baixa e os corpos de prova, ao serem ensaiados no triaxial de carga repetida, indicaram uma redução no módulo resiliente, porém, ainda com valores elevados;

- No ensaio de tração indireta não houve diferença entre a mistura de solo e 5\% de cimento, com e sem 30\% de escória, indicando que a escória não reduz a resistência à compressão por tração diametral;

- A forma angulosa e lisa dos grãos da escória contribui no ganho de resistência, rigidez, durabilidade e baixa permeabilidade, devido ao entrosamento com as partículas do solo;

- A dosagem físico-química é simples, rápida e serve para determinação do teor mínimo da dosagem do solo-cimento. Porém, os teores obtidos para as misturas não atingiram a resistência de 2,1MPa; 
- Apesar de um número limitado de dados, as equações e correlações desenvolvidas apresentaram boas relações com os valores de resistências dos ensaios;

- Das correlações obtidas, verifica-se que pontos com a mesma relação volume de vazios por volume de cimento apresentaram resistências diferentes, isto é, amostras com menores relações nem sempre alcançam resistências maiores e vice-versa;

- Das simulações do dimensionamento de pavimento, verifica-se que a espessura mínima foi de $25 \mathrm{~cm}$ para pavimento invertido e de $30 \mathrm{~cm}$ para base, ambos para a mistura de solo com $30 \%$ de escória e $5 \%$ de cimento.

\section{3}

\section{Recomendações para trabalhos futuros}

Os resultados obtidos nesta pesquisa, por outro lado, também colaboram no desenvolvimento de futuras investigações relacionadas ao tema, assim como já existem consideráveis pesquisa da utilização da escória de cobre no concreto. As recomendações estão descritas abaixo e outras ideias podem surgir durante novas pesquisas:

- Realizar outros ensaios aplicados ao tipo de uso do material em obras geotécnicas, incluindo-se ensaios de campo, penetração do ligante na camada de solo-cimento-escória, triaxiais convencionais, efeito do teor de umidade de compactação, efeito do umedecimento e secagem, etc.;

- Avaliar a potencialidade de novas misturas utilizando-se outros tipos de solos, por exemplo, para diminuir a expansão do solo ou criar uma camada drenante, dado os resultados positivos obtidos nesse estudo e a possibilidade de reutilização de um resíduo industrial;

- Adotar outras misturas empregando-se outros tipos de cimento, bem como outros estabilizantes (e.g. cal, cinzas, emulsões, polímeros) e analisar suas interações;

- Criar correlações envolvendo parâmetros como resistência, porosidade, teor de aditivos em misturas com aditivos; 
- Incorporar a escória de cobre pós-jateada como substituição parcial em misturas com ligantes asfálticos;

- Analisar a substituição de parte da fração areia do solo pela parte da fração areia da escória;

- Estudar a utilização da escória de cobre pós-jateada como material estrutural para solo reforçado;

- Realizar ensaios em grande escala como simulador de tráfego;

- Construir trechos experimentais utilizando o material estudado, monitorando o seu comportamento e interações ambientais no decorrer do tempo. 


\section{Referências bibliográficas}

ALEXANDRE, J.; ALVES, M.G.; LIMA, T.V. Estudo da estabilização de um solo argiloso com adição de cimento. Vértice, v. 8, n. 1/3, p.7-22, jan.-dez. 2006.

AL-JABRI, K.S.; TAHA, R.A.; AL-HASHMI, A.; AL-HARTHY, A.S. Effect of copper slag and cement by-pass dust addition on mechanical properties of concrete. Construction and Building Materials, v. 20, p. 322-331, 2006. AL-JABRI, K.S.; AL-SAIDY, A.H.; TAHA, R. Effect of copper slag as a fine aggregate on the properties of cement mortars and concrete. Construction and Building Materials, v. 25, p. 933-938, 2011.

AL-SAYED, M.H.; MADANY, I.M. Use of copper blasting grit waste in asphalt mixes in Bahrain. Construction and Building Materials, v. 6, n. 2, pp. 113-116, 1992.

ALTER, $\mathrm{H}$. The composition and environmental harzard of copper slag in the contexto of the Basel Convention. Resources, Conservation and Recycling, v. 43, p. 353-360, 2005.

AMERICAN COAL ASH ASSOCIATION (ACAA). Fly ash facts for highway engineers. 2003. Disponível em: <http://www.acaausa.org/Publications/AshatWork.aspx>. Acesso em: 17 abr. 2014.

AMERICAN SOCIETY FOR TESTING AND MATERIALS. D-3282: standard practice for classification of soils and soil-aggregate mixtures for highway construction purposes. Philadelphia, 2009.

C-51N: standard terminology relating to lime and limestone (as used by the industry). Philadelphia, 2011.

ANJOS, M.A.G. Aplicação da granalha batida de cobre como substituta parcial do agregado miúdo em concreto de cimento Portland. São Cristóvão: UFS, 2015. (Dissertação de Mestrado) ASSOCIAÇÃO BRASILEIRA DE NORMAS TÉCNICAS. NBR 12.253: solocimento - dosagem para emprego como camada de pavimento. Rio de Janeiro, 1992. 
NBR 10.004: resíduos sólidos - classificação. Rio de Janeiro, 2004.

NBR 1005: procedimento para obtenção de extrato lixiviado de resíduos sólidos. Rio de Janeiro, 2004.

. NBR 1006: procedimento para obtenção de extrato solubilizado de resíduos sólidos. Rio de Janeiro, 2004.

ASSOCIAÇÃO BRASILEIRA DE CIMENTO PORTLAND. Curso intensivo de solo-cimento. II COBRAMS, 1958.

A versatilidade do cimento brasileiro. Disponível em: < http://www.abcp.org.br/conteudo/basico-sobre-cimento/tipos/aversatilidade-do-cimento-brasileiro\#.VCHjPPIdWKg>. Acesso em 23 set. 2014.

Solo-cimento. Disponível em: <abcp.org.br/cms/basico-sobresolo-cimento/aplicacoes/solo-cimento>. Acesso em 23 set.2014.

ASSOCIAÇÃO BRASILEIRA DAS EMPRESAS DISTRIBUIDORAS DE ASFALTO (ABEDA). Manual básico de emulsão asfáltica. Soluções para pavimentar sua cidade. 2001. Disponível em: <http://www.abeda.org.br/>. Acesso em 22 maio 2014.

BARROS, K.S. Estudo sobre a possibilidade do uso de cinzas volantes advindas de uma termelétrica à carvão mineral da região metropolitana de Fortaleza -CE para aplicação em camadas granulares de pavimentos. Fortaleza: UFC, 2015 (Dissertação de Mestrado).

BASS, R.P. Hydraulic structures - designing with RCC and soil-cement. Water Resources, 2000.

BELINCANTA, A.; REIS, J.H.C.; NÓBREGA, M.T.; LUKIANTCHUKI, J.A. Estudo experimental de solos lateríticos do noroeste do Paraná aditivados com cimento Portland. In: CONGRESSO BRASILEIRO DE MECÂNICA DOS SOLOS, 13., 2006, Anais... 2006.

BERNUCCI L. B. et al. Pavimentação asfáltica. Formação básica para engenheiros. Rio de Janeiro: Petrobras, ABEDA, 2006. 501 p.

BERNUCCI, L.B.; VASCONCELOS, K.L.; SANBONSUGE, K.; RUFO, R.C.; NATO, A.M.C.; NASCIMENTO, L.A.H. Estudo comparativo de bases de pavimentos por meio de trechos monitorados: efeito da adição de cimento. 
In: REUNIÃO ANUAL DE PAVIMENTAÇÃO, 40., 2010, Rio de Janeiro. Anais... Rio de Janeiro, 2010.

BHARATI, S.K.; CHEN, S.H. Geotechnical behavior of recycled copper slag-cement-trated Singapore marine clay. Geotechnical and Geological Engineering. v. 34, p. 835-845, jun 2016.

CASANOVA, F.J. Fundamentos (mecanismo) da dosagem físico-química do solo-cimento. In: REUNIÃO DE PAVIMENTAÇÃO, 26., 1992, Aracaju. Anais... Aracaju, 1992. p. 88-110.

CASANOVA, F.J.; CERATTI, J.A.P.; RODRIGUES, M.G.M. Procedimento para dosagem físico-química do solo-cimento. In: REUNIÃO DE PAVIMENTAÇÃO, 26., 1992, Aracaju. Anais... Aracaju, 1992. p. 82-86.

CASTRO, E. Estabilização de solos, Curso de especialização 108, LNEC, Lisboa. 1970.

CASTRO, F.J.C.O. Um estudo físico-químico-matemático da estabilização alcalina de solos argilosos. Rio de Janeiro: UFRJ, 1981. (Dissertação de Mestrado).

CASTRO, G.R.; RABAÇA, S.R.; LUIS, A.D.; FERRI, S.; SANTOS, C.R.G.; LOPES, F.M.; SUZUKI, C.Y. Estabilização de solos in situ com uso de cimento Portland para composição das camadas de infraestrutura do pavimento do Rodoanel trecho Sul/SP. In: REUNIÃO DE PAVIMENTAÇÃO URBANA, 17., 2011, Porto Alegre. Anais... Porto Alegre, 2011.

CERATTI, J.A.P. Estudo do comportamento a fadiga de solos estabilizados com cimento para utilização em pavimento. Rio de Janeiro: UFRJ, 1991 (Tese de Doutorado).

CERATTI, J.A.P.; CASANOVA, F.J. Um método físico-químico para a dosagem de solo-cimento. In: SIMPÓSIO SOBRE NOVOS CONCEITOS EM ENSAIOS DE CAMPO E LABORATÓRIO EM GEOTECNIA. v. 1, p.191. Rio de Janeiro, 1988.

CHANG, T-S.; WOODS, R.D. Effect of particle contact bond on shear modulus. Journal of Geotechnical Engineering. v. 118, n. 8, p. 12161233, aug. 1992.

CHUN, B.S.; PARK, D.H.; JUNG, H.C.; CHOI, J.K. A study on the application of copper slag as a sand substitute of sand compaction pile. 
Proceeding of the Fifiteenth International Offshore and Polar Engineering Conference. Seoul, Korea. p. 19-24, jun 2005.

CONCHA, L.M.C. Estudo da fadiga de duas misturas de solo-cimento. Rio de Janeiro: UFRJ, 1986. (Dissertação de Mestrado).

CONSOLI, N.C.; FOPPA, D.; FESTUGATO, L.; HEINECK, K.S. Key parameters for strength control of artificially cemented soils. Journal of Geotechnical and Geoenvironmental Engineering. v.133, p. 197-205, feb. 2007.

CONSOLI, N.C.; PRIETTO, P.D.M.; CARRARO, J.A.H.; HEINECK, K.S. Behavior of compacted soil-fly ash-carbide lime mixtures. Journal of Geotechnical and Geoenvironmental Engineering. v. 127, n. 9, p. 774782, sept. 2001.

COSTA, J.V.B. Caracterização e constituição do solo. 7 ed. Lisboa: Fundação Calouste Gulbenkian, 2004.

CRISTELO, N.M.C. Estabilização de solos residuais graníticos através da adição de cal. Braga: Universidade do Minho, 2001. (Dissertação de Mestrado).

CROFT, J.B. The influence of soil mineralogical composition on cement stabilization. Geotechnique, n. 17, p. 119-135, 1967.

CRUZ, M.L.S. Novas tecnologias da aplicação de solo-cimento. Braga: Universidade do Minho, 2004. (Dissertação de Mestrado).

CRUZ, M.L.S.; JALALI, S. Melhoramento do desempenho de misturas de solo-cimento. Revista Luso'Brasileira de Geotecnia, Portugal, n. 120, p. 49-64, nov.2010.

DAS, B.M. Fundamentos de engenharia geotécnia. 6 ed. Tradução All Tasks; revisão técnica Pérsio Leister de Almeida Barros. São Paulo: Thomson Learning, 2007.

DEPARTAMENTO NACIONAL DE ESTRADA DE RODAGEM. DNER-ME 041: solos - preparação de amostras para ensaios de caracterização. Rio de Janeiro, 1994.

DNER-ME 049: solos - determinação do índice de suporte Califórnia utilizando amostras não trabalhadas. Rio de Janeiro, 1994.

DNER-ME 051: solos - análise granulométrica. Rio de Janeiro, 1994. 
DNER-ME082: solos - determinação do limite de liquidez. Rio de Janeiro, 1994.

. DNER-ME 093: solos - determinação da densidade real. Rio de Janeiro, 1994.

DNER-ME 122: solos-determinação do limite de plasticidade. Rio de Janeiro, 1994.

DNER-ME 129: solos - compactação utilizando amostras não trabalhadas. Rio de Janeiro, 1994.

DNER-ME 134: pavimentação - determinação do módulo de resiliência. Rio de Janeiro, 2010.

. DNER-ME 138: misturas betuminosas - determinação da resistência à tração por compressão diametral. Rio de Janeiro, 1994.

DNER-ME 194: Determinação da massa específica de agregados miúdos por meio do frasco de Chapman. Rio de Janeiro, 1994.

DNER-ME 201: solo-cimento - compressão axial de corpos-deprova cilíndricos. Rio de Janeiro, 1994.

DNER-ME 202: solo-cimento - moldagem e cura de corpos-deprova cilíndricos. Rio de Janeiro, 1994.

DNER-ME 203: solo-cimento - determinação da durabilidade através da perda de massa por molhagem e secagem. Rio de Janeiro, 1994.

DNER-ME 216: solo-cimento - determinação da relação entre o teor de umidade e a massa específica aparente. Rio de Janeiro, 1994.

DEPARTAMENTO NACIONAL DE INFRAESTRUTURA DE TRANSPORTE. Manual de Pavimentação. Publicação IPR - 719. $3^{\text {a }}$ ed. Rio de Janeiro, 2006. 274p.

DNIT-ES 139: pavimentação - sub-base estabilizada granulometricamente. Rio de Janeiro, 2010.

DNIT-ES 140: pavimentação - sub-base de solo melhorado com cimento. Rio de Janeiro, 2010.

DNIT-ES 141: pavimentação - base estabilizada granulometricamente. Rio de Janeiro, 2010.

DNIT-ES 142: pavimentação - base de solo melhorado com cimento. Rio de Janeiro, 2010. 
DNIT-ES 143: pavimentação - base de solo-cimento. Rio de Janeiro, 2010.

DEPARTAMENTO NACIONAL DE PRODUÇÃO MINERAL. Sumário mineral 2013. Disponível em: < http://www.dnpm.gov.br/dnpm/sumarios/sumario-mineral-2015>. Acesso em 14 nov. 2016.

DEPARTMENT OF THE ARMY, THE NAVY, AND THE AIR FORCE. Soil stabilization for pavements. Technical Manual $\mathrm{N}^{\circ}$ 5-822-14 Air Force Manual $N^{\circ}$ 32-1019. Washington, DC, 1994. 57 p. Disponível em: <http://www.wbdg.org/ccb/ARMYCOE/COETM/ARCHIVES/tm_5_822_14. pdf $>$. Acesso em 17 abr. 2014.

DIAS, J.F.M.S. Tratamento de solos com cimento para obtenção de melhores características mecânicas. Lisboa: Universidade Nova de Lisboa, 2012. (Dissertação de Mestrado).

DIAMOND, S.; KINTER, E.B. Mechanisms of soil-lime stabilization: na interpretative review. HRR., v. 92, pg 83. 1965.

DONGPING, T.; XIANWAN, Y.; ZHONG, YT.; JISHU, Y. Study of manufacture of colored glasses from slags of copper smelting. Yelian Bufen, 5. p. 41-43. 1997.

EMPRESA BRASILEIRA DE PESQUISA AGROPECUÁRIA (EMBRAPA). Levantamento de reconhecimento de média intensidade dos solos da região dos tabuleiros costeiros e da baixada litorânea do estado de Sergipe. Embrapa Solos. Volumes 1. Aracaju: Embrapa Tabuleiros Costeiros, 1999. 90 p. . Manual de métodos de análise de solo. Rio de Janeiro, $2^{2}$ ed. 1997. 212p.

ENAMORADO, M.A. Estudo comparativo entre o método mecânico e o método físico-químico para dosagem do solo-cimento. Rio de Janeiro: UFRJ, 1990. (Dissertação de Mestrado).

FARIAS, E.R. A utilização de misturas solo/cinza pesada na pavimentação - análise de aspectos de comportamento mecânico e ambiental. Florianópolis: UFSC, 2005. (Dissertação de Mestrado). FERNANDES, M.M. Mecânica dos solos. Introdução à engenharia geotécnica. 1 ed. V. 2. Porto: FEUP, 2011. 592 p. 
FERREIRA, C.; RIBEIRO, A.; OTTOSEN, L. Possible applications for municipal solid waste fly ash. Journal of Hazardous Materials. B $96 \mathrm{p}$. 201-216, july 2003.

FERREIRA, J.G.H.M. Elaboração e análise da base de dados de ensaios triaxiais dinâmicos. Rio de Janeiro, UFRJ/COPPE, 2002. (Dissertação de Mestrado).

FERREIRA, R.C.; FREIRE, W.J. Eficiência da estabilização do solo e qualidade de tijolos prensados de terra crua tratada com aditivos químicos, avaliados pela combinação de testes destrutivos e não destrutivos. Engenharia Agrícola, Jaboticabal, v. 24, n. 3, p. 501-511, set/dez 2004.

FONSECA, A.V.; CRUZ, R.C.; CONSOLI, N.C. Strength properties of Sandy soil-cement admixtures. Geotechnical Geology Engineering, v. 27, p. 681-686, 2009.

FONSECA, A.V.; NEVES, E.C. Evolução no tempo do comportamento mecânico de solos melhorados com cal aérea. Revista Luso-Brasileira de Geotecnia, Portugal, n. 124, p. 31-47, mar. 2012.

FOPPA, D. Análise de variáveis-chave no controle da resistência mecânica de solos artificialmente cimentados. Porto Alegre: UFRGS, 2005. (Dissertação de Mestrado).

FRANCO, F.A.C.P. Método de dimensionamento mecanístico-empírico de pavimentos asfálticos - SISPAV. Rio de Janeiro: UFRJ, 2007 (Tese de Doutorado).

GEISELER, J. Use of steelworks slag in Europe. Waste Management, v. 16, n.1-3, p. 59-63, 1996.

GONDIM, L.M. Estudo experimental de misturas solo-emulsão aplicado às rodovias do agropólo do Baixo Jaguaribe/Estado do Ceará. Fortaleza: UFC, 2009. (Dissertação de Mestrado).

GOH, A.T.; TAY, J.H. Municipal solid-waste incinerator fly ash for geotechnical applications. Journal Geotechnical Engineering. v. 119, issue 5, p. 811-825, may 1993.

GOTHE, C.A. Sistemas de controle e disposição final das cinzas do Complexo Termelétrico Jorge Lacerda - SC e da Usina Termelétrica de Jacuí - RS. In: SEMINÁRIO DE ESTUDOS DA APLICAÇÃO DOS 
RESÍDUOS DA COMBUSTÃO DO CARVÃO MINERAL, I e II, 1990, Florianópolis. Anais... 1ำ painel. Eletrosul. Florianópolis, 1990.

GUARÇONI, D.S.; MATTOS, A.B.G.; GONÇALVES, N.R. Estabilização de solos com betume. Técnicas de execução. In: REUNIÃO ANUAL DE PAVIMENTAÇÃO, 23., 1988, Florianópolis. Anais... Florianópolis, 1988. p. 448-483.

GUIMARÃES, J.E.P. A cal - Fundamentos e aplicações na engenharia civil. 2 ed. São Paulo: Pini, 2002. 341 p.

GOMES, C.F. Argilas - O que são e para que servem. Lisboa: Fundação Calouste Gulbenkian, 1986. 476 p.

GORAI, B.; JANA, R.K.; PREMCHAND. Characteristics and utilization of copper slag - a review. Resources, Conservation and Recycling, v. 39, p. 299-313, 2003.

HAMZAH, M.O. Conventional methods for highway soil stabilization.

Thesis submitted in partial fulfilment of the requirements for the degree of Master Science in Civil Engineering of the University of Strathclyde, Glasgow. 1983.

HARTLÉN, J. Environmental consequences of using residues. Waste Management, v. 16, n. 1-3, p. 1-6, 1996.

HERRIN, M.; MITCHELL, H. Lime-soil mixtures. Highway Research Board Bulletin, Washington, D.C., v. 304, p. 99-121. 1961.

HERZOG, A. Evidence for a skeleton-matriz structure in clays stabilized with Portland cemente. $5^{\text {th }}$ Australia - New Zealand Conference on SMFE. 1967.

INGLES, O.G. Mechanisms of clay stabilization with inorganic acids and álcalis. Aust. J. Soil, 8, 81, 1970.

INGLES, O.G.; METCALF, J.B. Soil stabilization - principles and practice. New York: John Wiley \& Sons. 1973.

JACINTHO, E.C. Estudo do comportamento de misturas solo-emulsão para uso em barragens. Brasília: UNB, 2005. (Dissertação de Mestrado). JACINTHO, E.C.; CARVALHO, J.C.; FARIAS, M.M.; GUIMARÃES, R.C. Influência das propriedades físicas, químicas e mineralógicas do solo no comportamento de misturas solo-emulsão. In: REUNIÃO ANUAL DE PAVIMENTAÇÃO, 36., 2005, Curitiba. Anais... Curitiba, 2005. 
JOEL, M; AGBEDE, I.O. Mechanical-Cement stabilization of laterite for use as flexible pavement material. Journal of Materials in Civil Engineering. n. 23, p. 146-152, feb. 2011.

JUNG, J.G.; STRACKE, F.; KORF, E.P.; CONSOLI, N.C. A influência do tipo de cimento na resistência à compressão simples de uma areia artificialmente cimentada. Revista Luso-Brasileira de Geotecnia, Portugal, n. 125, p. 87-94, jul. 2012.

KAMBHAM, K.; SANGAMESWARAN, S.; DATAR, S.R.; KURA, B. Copper slag: optimization of productivity and consumption for cleaner production in dry abrasive blasting. Journal of Cleaner Production, v. 15, p. 465-473, 2007.

KEZDI, A. Stabilized earth roads - developments in geotechnical engineering. Elsevier Company, 1979.

KEZDI A.; RETHATI, L. Handbook of soil mechanics - soil mechanics of Earthworks, foundations and highway engineering. Elsevier, Amsterdam, 3: 227-317 (1988).

KIM, B.; PREZZI, M.; SALGADO, R. Geotechnical properties of fly and bottom ash mixtures for use in highway embankments. Journal of Geotechnical and Geoenvironmental Engineering. p. 914-924, july 2005.

LAMBE, W; WHITMAN, R.V. Soil Mechanics. New York: John Wiley \& Sons, 1969. $582 \mathrm{p}$.

LASISI, F; OGUNJIDE, A.M. Effect of grain sinze on the strength characteristics of cement-stabilized lateritic soils. Building and Environment. v. 19, n. 1, p. 49-54, 1984.

LIMA, F.C. Estudo da compactação de misturas solo-emulsão para emprego em núcleo de barragem zoneadas. Ceará: UFC, 2016. (Dissertação de Mestrado).

LITTLE, D.N. Handbook for stabilization of pavement subgrades and base courses with lime. 1995, 219 p. Disponível em: <http://www.limetexas.org/publications/txt_5674140.pdf>. Acesso em 4 abr. 2014. 
LOPES, L.S.E. Análise do comportamento mecânico e ambiental de misturas solo-cinza de carvão mineral para camadas de base de pavimentos. Rio de Janeiro: PUC, 2011. (Dissertação de Mestrado).

LOVATO, R.S. Estudo do comportamento mecânico de um solo laterítico estabilizado com cal aplicado à pavimentação. Porto Alegre: UFRGS, 2004. (Dissertação de Mestrado).

MACÊDO, J.A.G. Interpretação de ensaios defletométricos para avaliação estrutural de pavimentos flexíveis. Rio de Janeiro: UFRJ/COPPE, 1996. (Tese de Doutorado).

MACÊDO, M.M. Solos modificados com cimento - efeito no módulo de resiliência e no dimensionamento de pavimentos. Recife: UFPE, 2004. (Dissertação de Mestrado).

MAKUSA, G.P. Soil stabilization methods and materials in engineering practice. Department of civil, environmental and natural resources engineering. Lulea University of Technology, 2012. Disponível em: $<$ https://pure.Itu.se/portal/files/42050076/Soil_stabilization_methods_and_ materials.pdf>. Acesso em 3 abr. 2014.

MALLMANN, J.E.C. Estabilização pozolânica de cinzas volantes e pesada com cal dolomítica hidratada e areia, curada pelos processos de autoclavagem e câmara à temperatura constante. Porto Alegre: UFRGS, 1996. (Dissertação de Mestrado).

MARGHUSSIAN, V.K.; MAGHSOODIPOOR, A. Fabrication of unglazed floor tiles containing Iranian copper slag. Ceramics International, v. 25, p. 617-622, 1999.

MARANGON, M. Utilização de solo-cimento em uma solução alternativa de estrutura de arrimo. Rio de Janeiro: PUC, 1992. (Dissertação de Mestrado).

MARCON, A.F. Durabilidade e módulo de elasticidade de misturas areia-cal-cinza volante. Rio de Janeiro: UFRJ, 1977. (Dissertação de Mestrado).

MATEOS, M. Physical and mineralogical factors in stabilization of lowa Soils. PH.D. Thesis, lowa State University, 1961. 
MATTOS, A.B.G. Estabilização de solo com betume. In: REUNIÃO ANUAL DE PAVIMENTAÇÃO, 25., 1991, São Paulo. Anais... I Sessão Técnica Materiais e Ensaios de Laboratório. São Paulo, 1991. p. 85-197.

MEYERSOHN, W.D. Use of soil-cement piles for bridge support. Geotechnical Special Publication №158 Deep Foundations, 2007. MICELI JÚNIOR, G. Comportamento de solos do estado do Rio de Janeiro estabilizados com emulsão asfáltica. Rio de Janeiro: Instituto Militar de Engenharia, 2006. (Dissertação de Mestrado).

MINISTÉRIO DE MINAS E ENERGIA (MME). Relatório técnico 23. Perfil da mineração de cobre. Produto 14. Minério de cobre. Ago. 2009. 69p. Disponível em: <http://www.mme.gov.br/sgm/galerias/arquivos/plano_duo_decenal/a_min eracao_brasileira/P14_RT23_Perfil_da_Mineraxo_de_Cobre.pdf> Acesso em: 18 jul. 2014.

MITCHELL, J.K. Fundamentals of soil behavior. New York: John Wiley \& Sons, 1969. 582 p.

MOTTA, L.M.G; MACÊDO, M.M. Comportamento de solo melhorado com cimento para uso em pavimentação sob carga repetida. In: CONGRESSO LUSO-BRASILEIRO DE GEOTECNIA DE INFRA-ESTRUTURA DE TRANSPORTE, III, 2006, Curitiba. Anais... Curitiba, 2006.

MOURA, W.A. Utilização de escória de cobre como adição e como agregado miúdo para concreto. Porto Alegre: UFRGS, 2000. (Tese de Doutorado).

MOURA, W.A.; GONÇALVES, J.P.; LEITE, M.B. Avaliação de propriedades mecânicas de concretos contendo escória de cobre como agregado miúdo. REM: R. Esc. Minas, Ouro Preto, v. 62, n. 2, p. 221-225, abr.-jun. 2009. MURARI, K.; SIDDIQUE, R.; JAIN, K.K. Use of waste copper slag, a sustainable material. Journal Mater Cycler Waster Manag, vol. 17, p. 1326, 2015.

NARDI, J.V. Estabilização de areia com cinza volante e cal; efeito do cimento como aditivo e de brita na mistura. Rio de Janeiro: UFRJ, 1975. (Dissertação de Mestrado). 
OLIVEIRA, L.C.D. A estabilização de solos aplicada a habitação, um estudo de misturas solo-cimento. Rio de Janeiro: UFRJ, 1994. (Dissertação de Mestrado).

PEREIRA, O.A. Estabilização de solos, Curso de Especialização 108, LNEC, Lisboa.

PESSOA, F.H.C.; CARVALHO, J.C.; GOUVEIA, L.A. Análise da estabilização química de solos finos da região amazônica com cimento Portland. In: REUNIÃO DE PAVIMENTAÇÃO URBANA, 16., 2009, Belo Horizonte. Anais... Belo Horizonte, 2009.

PETRUCCI, E.G.R. Concreto de cimento Portland. 14 ed. São Paulo: Globo, 2005. 307 p.

PINTO, C.S. Curso básico de mecânica dos solos. 3 ed. São Paulo: Oficina de Texto, 2006.

PINTO, S. Estabilização de areias com adição de cal e cinza volante.

Rio de Janeiro: UFRJ, 1981. (Dissertação de Mestrado).

PORTELINHA, F.H.M.; LIMA, D.C.; FONTES, M.P.F.; CARVALHO, C.A.B.; STEHLING, R.S. Influência dos mecanismos de reação nas propriedades físicas e químicas de dois solos tropicais melhorados com cimento e cal. Revista Luso-Brasileira de Geotecnia, Portugal, n. 124, p. 5-30, mar. 2012.

PORTLAND CEMENT ASSOCIATION. What is soil-cement. Disponível em : < http://www.cement.org/think-harder-concrete-/paving/soil-cement>. Acesso em 21 mar. 2014.

Soil - cement inspector's manual. 2001. Disponível em: $<$ http://www.cement.org/docs/default-source/th-pavingpdfs/soil_cement/pa050-03_reduced-size.pdf?sfvrsn=2>. Acesso em: 21 mar. 2014.

PRASAD, P.S.; RAMANA, G.V. Feasibility study of copper slag as a structural fill in reinforced soil structures. Geotextiles and Geomembranes, v. 44, p. 623-540, 2016.

PROCOBRE - Instituto Brasileiro do Cobre. História. Disponível em: < http://procobre.org/pt/o-cobre/historia/>. Acesso em: 24 ago. 2014. 
PUPPALA, A.J. Advances in ground modification with chemical additives: from theory to practice. Transportation Geotechnics, v. 9, p. 123-138, 2016.

RAPOSEIRAS, A.C.; VARGAS-CERÓN, A.; MOVILLA-QUESADA, D.; CASTRO-FRESNO, D. Effect of copper slag addition on mechanical behavior of asphalt mixes containing reclaimed asphalt pavement. Construction and Building Materials, v. 119, p.268-276, 2016.

RESENDE, C.M.A. Estudo da viabilidade de incorporação de escória de cobre como agregado fino em produtos de construção. Porto, FEUP, 2009. (Dissertação de Mestrado).

RODRIGUES, M.G.M. Contribuição ao estudo do método físicoquímico de dosagem do solo-cimento. Rio de Janeiro: UFRJ, 1992. (Dissertação de Mestrado).

ROHDE, G.M.; ZWONOK, O.; CHIES, F.; SILVA, N.I.W. Cinzas de carvão fossil no Brasil - Aspectos técnicos e ambientais. Volume 1. Porto Alegre: CIENTEC, 2006.

ROSA, A.D. Estudo dos parâmetros-chaves no controle da resistência de misturas solo-cinza-cal. Porto Alegre: UFRGS, 2009. (Dissertação de Mestrado).

SANBONSUGE, K. Comportamento mecânico e desempenho em campo de base de solo-cimento. São Paulo: USP, 2013. (Dissertação de Mestrado).

SANT'ANA, W.C. Contribuição ao estudo de solo-emulsão em pavimentos de rodovias de baixo volume de tráfego para o Estado do Maranhão. São Paulo: USP, 2009. (Tese de Doutorado).

SANTANA, F.I.T. Estudos sobre misturas de agregados reciclados de resíduos da construção civil com solos para utilização em pavimentos. São Cristóvão: UFS, 2014. (Dissertação de Mestrado).

SANTANA, R.R. Estudo da estabilidade de estocagem do CAP 50/70 modificado com resíduo industrial e avaliação da sua influência em mistura do tipo CAUQ dosada pelos métodos Marshall e Superpave. São Cristóvão: UFS, 2016. (Dissertação de Mestrado). 
SANTOS, J.F.R. Estudos da formulação de solo-cimento e solo-cal e respectivas aplicações. Porto: Instituto Superior de Engenharia do Porto, 2008. (Dissertação de Mestrado).

SANTOS, P. S. Tecnologia de argilas aplicadas às argilas brasileiras. V.1. São Paulo: Blücher, 1975. 340p.

SANTOS, W.J. Avaliação do uso de emulsão asfáltica na estabilização química de três solos de Sergipe. Campina Grande: UFCG, 2009. (Dissertação de Mestrado).

SENÇO, W. Manual de técnica de pavimentação. 1.ed. Volume 2. São Paulo: Pini, 2001. 671 p.

SHERWOOD, P.T. Soil stabilization with cement and lime - state of the art review. Transport Research Laboratory, HMSO, London. 1993.

SHI, C.; MEYER, C.; BEHNOOD, A. Utilization of copper slag in cement and concrete. Resources, Conservation na Recycling, v. 52, p. 1115-1120, 2008.

SILVA, W.P.; SILVA, C.M.D.P.S. Lab Fit ajuste de curvas (regressão nãolinear e tratamento de dados) V 7.2.19 (2003-2004). CD-ROM.

SOUZA, A.; CARVALHO, D.; BARROSO, F.S. Estudo da estabilização do solo superficial arenoso do noroeste do estado de São Paulo com utilização de cimento. In: CONGRESSO BRASILEIRO DE MECÂNICA DOS SOLOS, 11., 1998, Anais... 1998. p. 1117-1124.

SPECHT, L.P. Comportamento de misturas solo-cimento-fibra submetidas a carregamentos estáticos e dinâmicos visando a pavimentação. Porto Alegre: UFRGS, 2000. (Dissertação de Mestrado).

STOCKER, P.T. Diffusion and diffuse cementation in lime and cement stabilized clayey soils. ARRB SEPC - Report, n॰ 8, 1972.

SZYRLE, W.; WOZNIAK, K.; MAKOWSKI, M.; KOZLOWSKI, A. Resin binder for bonding abrasive particles in grinding wheels. Pol PI. p. 143-178. 1988.

THOMÉ, A.; DONATO, M.; CONSOLI, N.C.; GRAHAM, J. Circular footings on a cemented layer above weak foundation soil. Can. Geotch. J. v. 42, p. 1569-1584, 2005. 
TREMBLAY, H.; DUCHESNE, J.; LOCAT, J.; LEOUEIL, S. Influence of the nature of organic compounds on fine soil stabilization with cement. Can. Geotech. J. v. 39, p. 535-546, 2002.

VARGAS, M. Introdução à mecânica dos solos. São Paulo: MCgraw-Hill do Brasil, Ed. da Universidade de São Paulo, 1977. 509 p.

VIANA, H.M.F. Estudo do comportamento resiliente dos solos tropicais grossos do interior do estado de São Paulo. São Carlos: USP, 2007. (Tese de Doutorado).

VILLAR FILHO, O.C.; LUCENA, F.B.; FERREIRA, H.C. Estabilização de solos lateríticos com cimento. In: CONGRESSO BRASILEIRO DE MECÂNICA DOS SOLOS E ENGENHARIA DE FUNDAÇÕES, 7., 1982, Olinda/Recife. Anais... Olinda/Recife, 1982. p. 285-305.

VIZCARRA, G.O.C. Aplicabilidade de cinzas de resíduos sólidos urbano para base de pavimentos. Rio de Janeiro: PUC, 2010. (Dissertação de Mestrado).

ZAIN, M.F.M.; ISLAM, M.N.; RADIN, S.S.; YAP, S.G. Cement-based solidification for the safe disposal of blasted copper slag. Cement \& Concrete Composites, v. 26, p. 845-851, 2004.

YODER, E.J.; WITCZAK, M.W. Principles of pavement design. 2 ed. New York: John Wiley \& Sons, 1975.

YOON, S.; BALUNAINI, U.; YILDIRIM, I.Z.; PREZZI, M.; SIDDIKI, N.Z. Construction of an embankment with a fly and bottom ash mixture: field performance study. Journal of Materials in Civil Engineering. v. 21, n. 6, june 2009. 